Gecse Gergely:

A kis- és középvállalkozások logisztikai gyakorlatának vizsgálata 


\section{Budapesti CORVINUS Egyetem \\ Vállalatgazdaságtan Intézet \\ Logisztika és Ellátási Lánc Menedzsment Tanszék}

Témavezető: Halászné dr. Sipos Erzsébet

(C) Gecse Gergely

Minden jog fenntartva! 


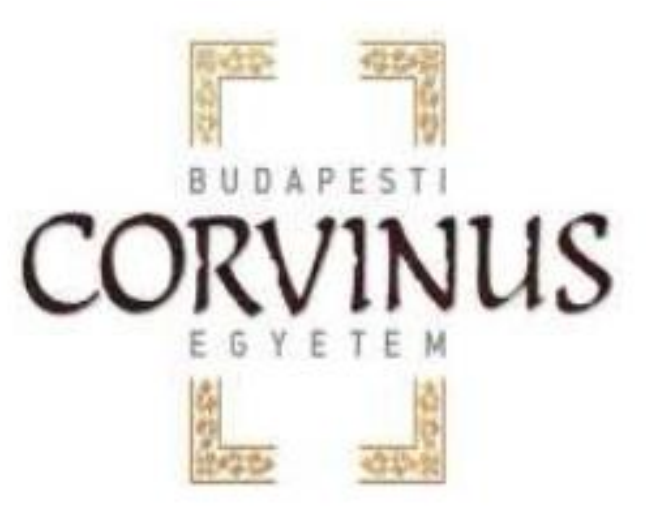

Budapesti CORVINUS

Egyetem

Gazdálkodástani Doktori iskola

\title{
A kis- és középvállalkozások logisztikai gyakorlatának vizsgálata
}

\author{
Ph.D. értékezés
}

\begin{abstract}
Gecse Gergely
Vállalatgazdaságtan Intézet

Logisztika és Ellátási Lánc Menedzsment Tanszék
\end{abstract}

Témavezető: Halászné dr. Sipos Erzsébet

Budapest, 2012. 



\section{Tartalomjegyzék}

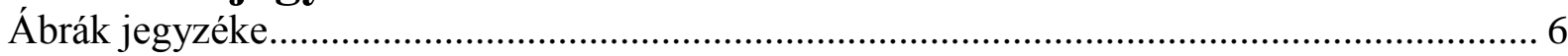

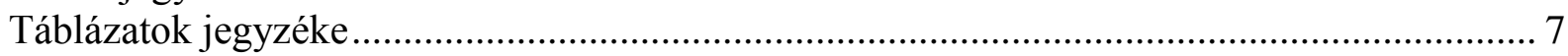

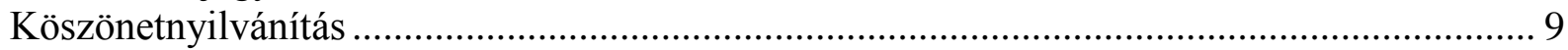

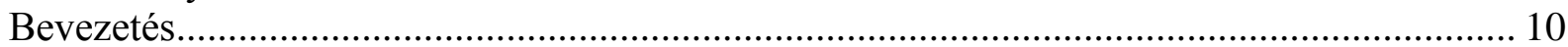

1. A kis- és középvállalkozás, valamint a logisztika fogalmának értelmezése ................... 12

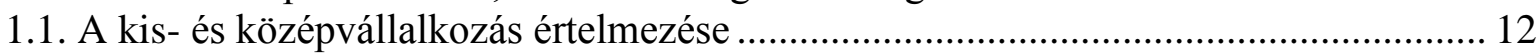

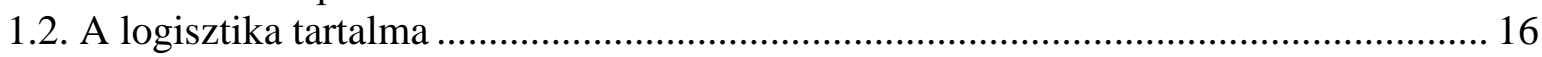

2. Kis- és középvállalkozásokra vonatkozó logisztikai kutatások ..................................... 18

2.1. Logisztika értelmezése és jelentősége a KKV-k esetében ........................................ 19

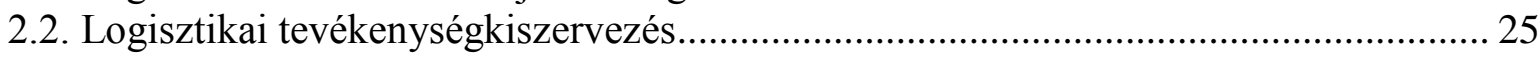

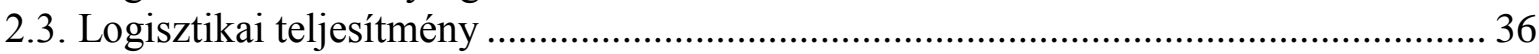

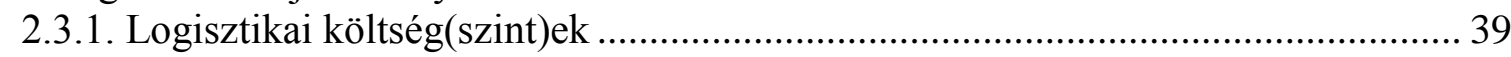

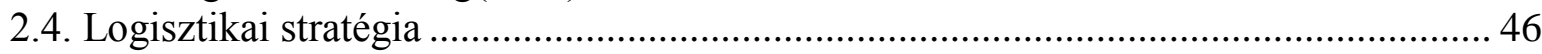

2.5. A logisztika szervezeti megjelenése, koordinációja, alkalmazottak képzése ................51

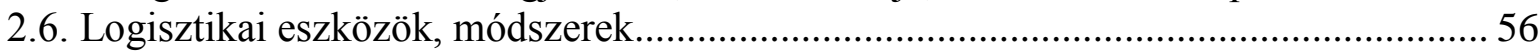

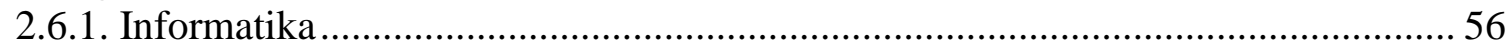

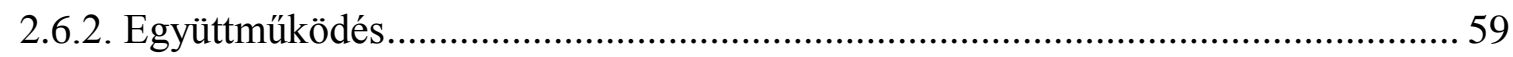

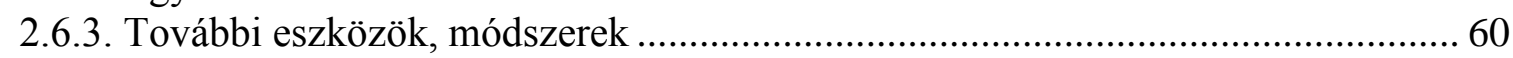

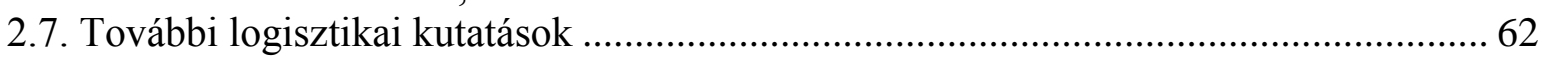

2.8. A szakirodalom feldolgozás összefoglaló következtetései ...................................... 65

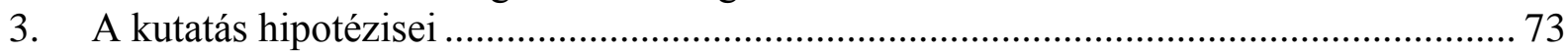

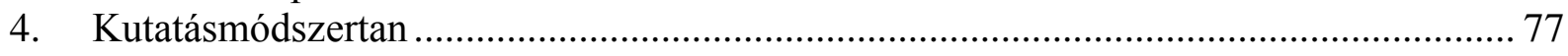

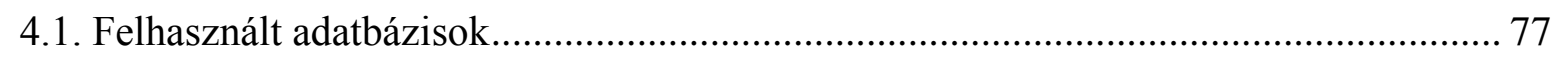

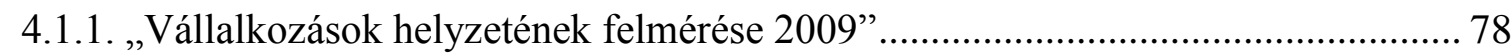

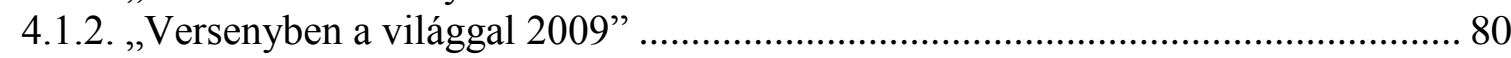

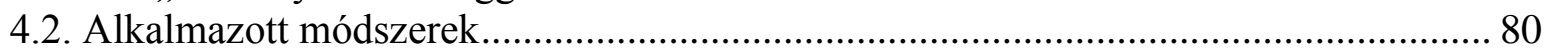

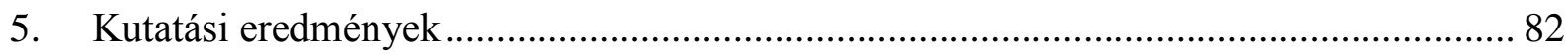

5.1. A „Vállalkozások helyzetének felmérése 2009” adatbázis logisztikai

költségszint és outsourcing változóinak vizsgálata ........................................................ 83

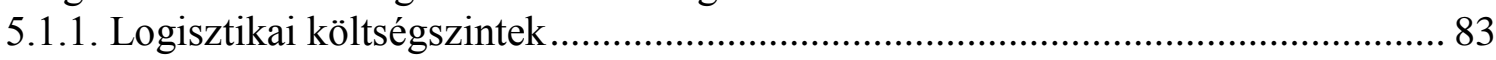

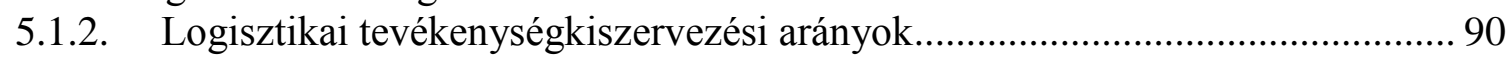

5.1.3. Logisztikai költségszintek vs. tevékenységkiszervezési arányok ....................... 95

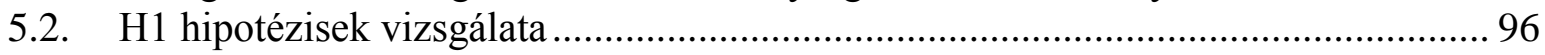

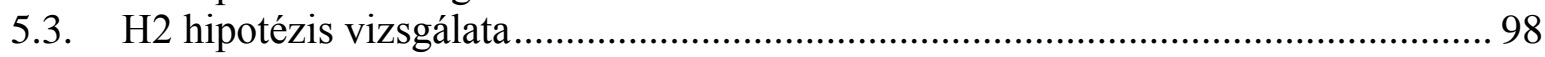

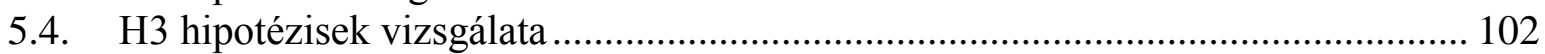

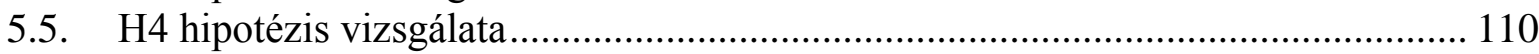

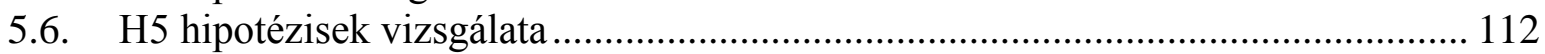

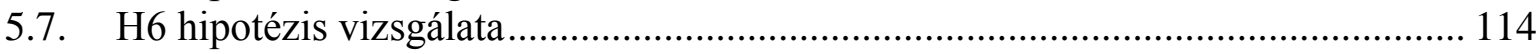

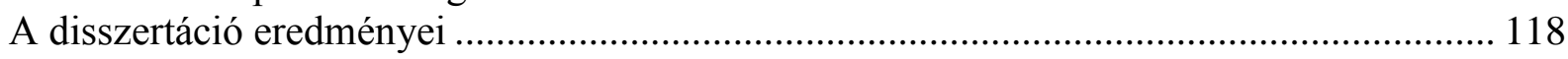

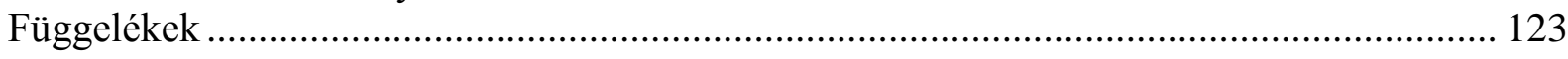

1. függelék: „Vállalkozások helyzetének felmérése 2009” kutatás felhasznált

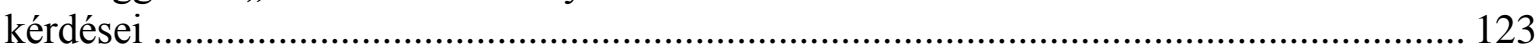

2. függelék: „Versenyben a világgal 2009” kutatás felhasznált kérdései ...................... 129

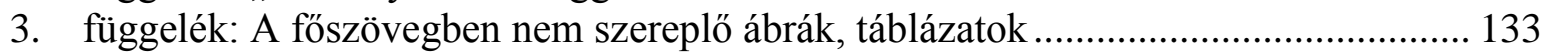

4. függelék: A disszertációban használt rövidítések jegyzéke ....................................... 144

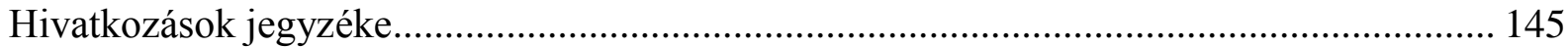

A témában a disszertáció benyújtásáig született publikációim jegyzéke............................. 154 


\section{Ábrák jegyzéke}

1. ábra: A logisztikai integráció fejlődése. 16

2. ábra: A logisztikai folyamat kezdete és vége a magyar termelő KKV-knál ....................... 20

3. ábra: A logisztikai jelentősége a finn feldolgozóipari és kereskedelmi

vállalkozásoknál.

4. ábra: Kiszervezni kívánt logisztikai szolgáltatások iránti kereslet német nagy- és a kisvállalatok körében 32

5. ábra: Kulcsmutatók nyomonkövetése és használata finn vállalkozásoknál ....................... 38

6. ábra: Norvég feldolgozóipari, kereskedelmi és építőipari vállalkozások logisztikai költségszintjei 2007-ben 42

7. ábra: Finn feldolgozóipari és kereskedelmi vállalkozások logisztikai

költségszintjeinek változása $(2005,2008,2009)$ .. .43

8. ábra: Balti-tengeri térségi vállalkozások logisztikai költségszintjei 2006-2007-ben........... 44

9. ábra: Logisztikai tényezők fontossága a német KKV-k stratégiai tervezésében ................. 47

10. ábra: Logisztikai koncepciók bevezetésének okai a német KKV-k körében .................... 48

11. ábra: Német KKV-k logisztikai fejlődési szintjeinek megoszlása .................................. 49

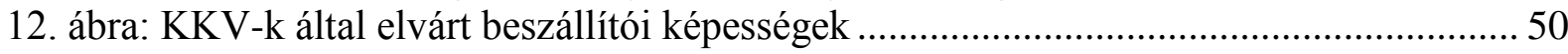

13. ábra: A logisztikai funkció vállalaton belül elképzelt helye Németországban ..................52 52

14. ábra: Információs rendszerek használata finn vállalatok rendelés- és

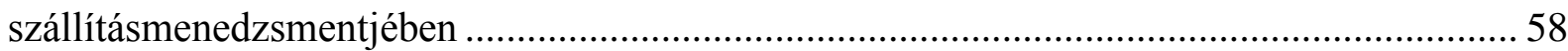

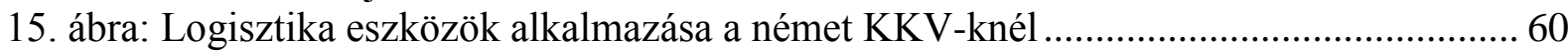

16. ábra: A legfontosabb finn fejlesztési igényeik vállaltméret szerint ................................. 61

17. ábra: Közép-kelet-európai országok középvállalkozásainak konténereljuttatási ideje,

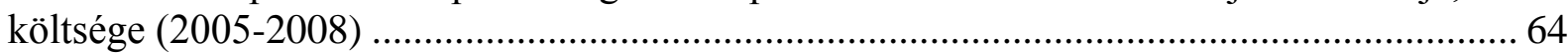

18. ábra: Logisztikai tevékenységkiszervezés döntési modellje ....................................... 75

19. ábra: Európai országok rangsora a Logistics Performance Index alapján, 2009 .............. 82

20. ábra: Magyarországi KKV-k logisztikai költségszintjei vállalatméret szerint, 2009 ........ 83

21. ábra: Magyarországi KKV-k logisztikai költségszintjei ágazat szerint, 2009 ................. 85

22. ábra: Logisztikai tevékenységkiszervező KKV-k aránya vállalatméret alapján, 2009 ...... 90

23. ábra: Logisztikai tevékenységeiket kiszervező KKV-k aránya ágazatonként, 2009 ......... 91

24. ábra: Társas KKV szállítás és raktározás kiszervezésének változása a 2009-öt követő 5 évben 101

25. ábra: Logisztikai részköltségek és összköltség hisztogrammjai a normál eloszlással (H1 hipotézisek) .............................................................................................. 134

26. ábra: Logisztikai tevékenységkiszervezések hisztogrammjai a normál eloszlással (H1 hipotézisek)

27. ábra: Teljesítmény-klaszterek dendrogrammja (H5 hipotézisek) 


\section{Táblázatok jegyzéke}

1. táblázat: Ország-specifikus KKV meghatározások................................................. 13

2. táblázat: A kis- és középvállalkozások Európai Unióban használt besorolása ................ 14

3. táblázat: EU-27, illetve magyarországi vállalkozások száma és aránya (2010) ............. 16

4. táblázat: Német vállalatok logisztika értelmezése méret szerinti bontásban .................. 22

5. táblázat: A tranzakciók jellemzőinek költségvonzatai ................................................. 25

6. táblázat: Nemzetközi kereskedelembe kapcsolódott amerikai kis- és nagyvállalatok

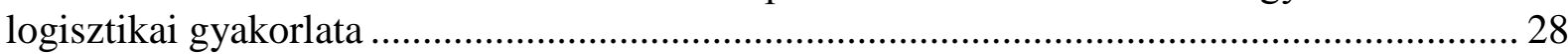

7. táblázat: Magyarországi KKV-k logisztikai tevékenységkiszervezése.......................... 33

8. táblázat: Logisztikai költségek egy lehetséges felosztása ............................................ 41

9. táblázat: Formalizált logisztikai szervezet quebeci vállalkozásoknál .............................52

10. táblázat: Müködő logisztikai osztályok aránya német KKV-knál vállalatméret

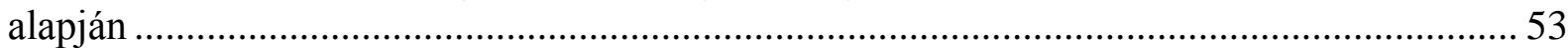

11. táblázat: A logisztika legmagasabb szintje a quebeci vállalkozások vezetésében ........ 54

12. táblázat: Az elmúlt öt évben legalább egy alkalmazottját továbbképző quebeci

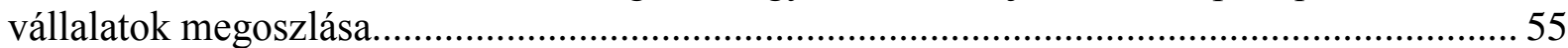

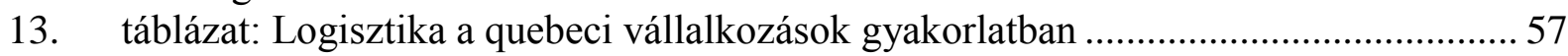

14. táblázat: A disszertációban feldolgozott KKV logisztikai kutatások a KKV

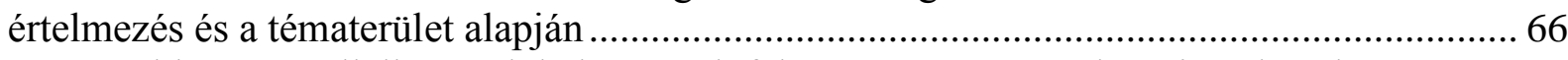

15. táblázat: „Vállalkozások helyzetének felmérése 2009” gazdasági ágak és létszám

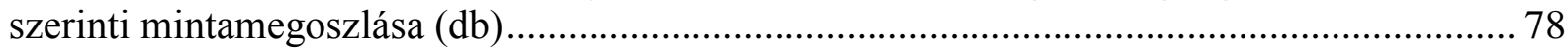

16. táblázat: A „Versenyben a világgal 2009” felmérés gazdasági ágak és létszám

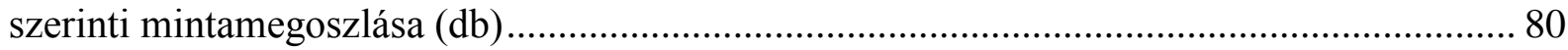

17. táblázat: A kutatás során alkalmazott módszerek …................................................ 81

18. táblázat: Egyes logisztikai részköltségek változásának 1-5 Likert-skálán mért értékeinek átlaga a 2009-et megelőző három évben ............................................................. 84

19. táblázat: A nulla logisztikai összköltségről számot adó magyar KKV-k aránya

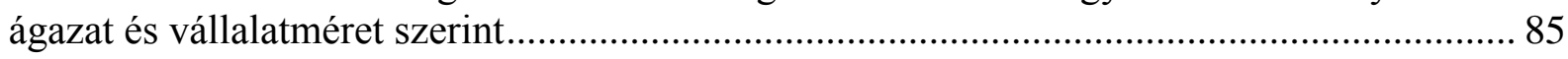

20. táblázat: Logisztikai összköltség és részköltségek adott szempont szerinti

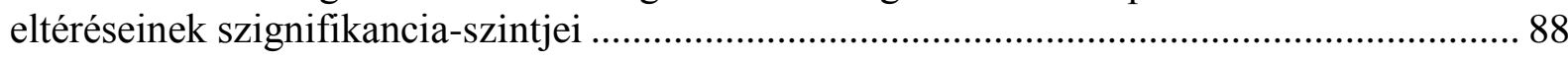

21. táblázat: Logisztikai résztevékenységek kiszervezése a „Versenyben a világgal

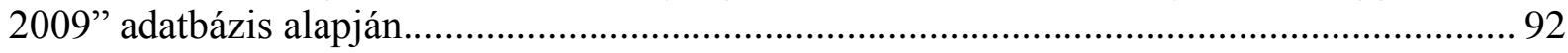

22. táblázat: Logisztikai tevékenységkiszervezési szintek rotált komponens mátrixa ....... 92

23. táblázat: Logisztikai tevékenységkiszervezések adott szempont szerinti eltéréseinek szignifikancia-szintjei ...

24. táblázat: Egyes logisztikai költségek és kiszervezési szintek Pearson-féle korrelációi

25. táblázat: Logisztikai költségekre és tevékenységkiszervezésre ható tényezők éta értékei97

26. táblázat: Logisztikai tevékenységek költségcsökkentésére adott válaszok

27. táblázat: Kiszervezés érveinek páronkénti asszociációját mutató Cramer V mértékek

28. táblázat: A szállítást, raktározást és csomagolást alapvető képességüknek tekintő magyarországi mezőgazdasági, feldolgozóipari és kereskedelemi KKV-k....

29. táblázat: A magyarországi mezőgazdasági, feldolgozóipari és kereskedelemi

KKV-k tranzakciós költségeinek változása

30. táblázat: Logisztikai tevékenységkiszervezés és annak okai közötti kapcsolat erőssége a mezőgazdasági, feldolgozóipari és kereskedelmi KKV-k körében 106

31. táblázat: Logisztikai tevékenységkiszervezés okainak egyedi hatásai 108 
32. táblázat: Logisztikai tevékenységkiszervezés okainak együttes hatásai 109

33. táblázat: Legalább öt különböző módszerrel létrejött faktorstruktúrák

34. táblázat: Vállalati teljesítményklaszterek és logisztikai rendszer hatékonyságának összefüggései.

35. táblázat: A beszerzés, készletgazdálkodás és logisztika szerepe az összvállalati sikerben, vállalatméret és különböző vállalati vezetők szerint

36. táblázat: A logisztikai részterületek sikerben betöltött szerepének vezetők általi rangsorban elfoglalt helyének minimuma, maximuma vállalatméret szerint

37. táblázat: A logisztikai részterületek sikerben betöltött szerepének vezetők általi rangsorban elfoglalt helyének (szign. korrigált) minimuma, maximuma vállalatméret szerint

38. táblázat: Egyszerre több logisztikai résztevékenységet kihelyező magyarországi

KKV-k logisztikai funkció variációi

39. táblázat: Egyes logisztikai költségek és kiszervezési szintek összefüggései a mezőgazdasági, feldolgozóipari és kereskedelmi KKV körében.

40. táblázat: Logisztikai költség és tevékenységkiszervezés elemek Levene tesztjeinek szignifikancia-szintjei (H1 hipotézisek)

41. táblázat: Logisztikai költségekre és tevékenységkiszervezésre ható tényezők éta értéke (mezőgazdaság, feldolgozóipar, kereskedelem) (H1 hipotézisek)

42. táblázat: Kiszervezés érveinek páronkénti asszociációját mutató Cramer V

mértékek, mezőgazdaság, feldolgozóipar, kereskedelem (H3 hipotézisek)

43. táblázat: Mikrovállalkozások müködési területeinek súlya az összvállalati siker szempontjából és azok különbségei (H6 hipotézis)

44. táblázat: Kisvállalkozások működési területeinek súlya az összvállalati siker szempontjából és azok különbségei (H6 hipotézis)

45. táblázat: Középvállalkozások müködési területeinek súlya az összvállalati siker szempontjából és azok különbségei (H6 hipotézis)

46. táblázat: Nagyvállalatok müködési területeinek súlya az összvállalati siker

szempontjából és azok különbségei (H6 hipotézis) 


\section{Köszönetnyilvánítás}

A disszertációm megírását közvetlenül és közvetett módon nagyon sokan segítették, melyet ezúton szeretnék megköszönni legfőképpen témavezetőmnek Halászné Sipos Erzsébetnek, aki a doktori tanulmányaim alatt számos értékes és hasznos tanáccsal látott el.

Hálával tartozom az elméleti háttér feltárását, az adatfelvétel kialakítását és végrehajtását, valamint a disszertációm végleges változatának elkészítését elősegítő kollégáimnak, különösen:

- a Budapesti Corvinus Egyetem Vállalatgazdaságtan Intézet tagjainak, elsősorban Czakó Erzsébet intézetvezetőnek és Gelei Andrea tanszékvezetőnek, valamint

- Kállay Lászlónak és az egykor általa vezetett Nemzeti Fejlesztési és Gazdasági Minisztérium kis- és középvállalkozás fejlesztéséért felelős föosztály munkatársainak Kissné Kovács Eszternek és Kőhegyi Kálmánnak.

Bárdos Krisztina disszertáció-tervezetemhez adott bírálata is hozzájárult ahhoz, hogy a kutatásom szakmai színvonala lényegesen javult.

Hálával tartozom Páromnak is, aki türelemmel viselte a gyakran éjszakába nyúló elemzéseimet és aki a szöveg, a táblázatok és az ábrák tengeréből a legapróbb hibákat is segített kiszürni, emellett a munkámat mindig ösztönző Édesanyámnak, aki a disszertációm elkészültét sajnos már nem élhette meg.

A PhD disszertáció a TÁMOP-4.2.1/B-09/1/KMR-2010-0005 projekt támogatásával készült. 


\section{Bevezetés}

2010-ben az Európai Unió 20,839 millió vállalkozásának 99,8\%-a volt kis- és középvállalkozás (a továbbiakban: KKV), ahol a 130,718 millió foglalkoztatott 66,9\%-a dolgozott. (Wymenga et al. [2011]) Magyarországon ugyanekkor a becslések szerint az 547,7 ezer ipari, kereskedelmi és szolgáltató vállalkozás 99,9\%-át, a vállalkozásoknál alkalmazottak 71,7\%-át, a hozzáadott érték 54,6\%-át adták a kis- és középvállalkozások. (European Commission [2011]) A gazdaságban betöltött jelentős súlyuk, rugalmasságuk, innovativitásuk, gyors döntéshozataluk miatt a KKV-k gyakran kutatott területnek számítanak. Sajnos ez a logisztikájukról nem mondható el, melyről nagyon kevés felmérés áll rendelkezésre. Nagyon sok a logisztikai szakértők által széles körben elfogadott hipotézis, melyre két példa:

- „A legtöbb kisvállalat sem operatívan, sem stratégiailag nem fedezte fel a logisztikát. A best practice kifejezést hallva worst practice-ről beszélhetünk.” (La Londe, idézi Harrington [1995] p. 55.)

- „A KKV-knél gyakori az a nézet, hogy a logisztikát másodlagosan lehet kezelni. A szállítást, raktározást és anyagmozgatást szükséges rossznak kell tekinteni.” (Kummer, [1995] p. 10.)

Disszertációmban a nemzetközi és hazai KKV logisztikai kutatások eddigi legszélesebb körű feltárását végeztem el, szisztematikusan összegyüjtve és feldolgozva a legtöbbször a „szürke” irodalomba ${ }^{1}$ tartozó, gyakran helyi nyelveken publikált kutatásokat. Ezek eredményeit összefoglalva a magyarországi kis- és középvállalkozások logisztikai gyakorlatát vizsgáltam mélyebben. Az eddigi relatíve egyszerü matematika-statisztikai módszereket alkalmazó kutatásokon túllépve a célom a kis- és középvállalkozások logisztikájának további tudományos vizsgálatának elősegítése volt. Emellett szerettem volna megmutatni, hogy a területre fordított nagyobb figyelem a KKV-k teljesítményének növeléséhez, a logisztikai szolgáltatóknak pedig piacbővüléshez vezethetne. Remélem, hogy vizsgálataimmal hozzájárulok ahhoz, hogy a nagyvállalatok logisztikai gyakorlata a kis- és középvállalkozások szintjén is megjelenjen, és

\footnotetext{
${ }^{1}$ „Korántsem teljes és elvszerủ felsorolással élve a kutatás-fejlesztési beszámolók, a disszertációk és habilitációs munkák, a konferenciaanyagok ..., bizonyos fordítások, vizsgálati jelentések és állami, önkormányzati dokumentumok tartoznak ide.” (Futala és Mohor [1995], p. 65)
} 
mindennapossá váljon és ezzel „a KKV-ket felébresszük logisztikai álmukból”. (Stabenau, idézi Kummer [1995] előszavában)

Kutatásomban a kis- és középvállalkozások logisztikai költségeit és tevékenységkiszervezését befolyásoló tényezőket, a logisztikai outsourcingban rejlő potenciált és a megítélésének hátterében álló okokat vizsgáltam. Emellett a logisztika és a vállalati teljesítmény kapcsolatát, valamint az összvállalati siker szempontjából a logisztikai tevékenység vezetők általi megítélését kutattam. Ehhez a 2009-ben negyedik alkalommal elvégzett, háromszáz vállalatot (85,6\%-uk KKV) vizsgáló „Versenyben a világgal kutatás", illetve a gazdasági tárca által 2009-es reprezentatív, közel kétezer kisés középvállalkozásra kiterjedő „Vállalkozások helyzetének felmérés”-ének logisztikára vonatkozó kérdéseit használtam fel. A kutatáshoz a különbségek szignifikáns voltának vizsgálatai (pl. Kruskal-Wallis, Mann-Whitney, összetartozó mintás t- és Wilcoxon próbák) mellett többváltozós matematikai-statisztikai módszereket használtam fel a szórás- és kereszttábla elemzésektől, a bináris logisztikus regresszión át a klaszter-, illetve faktorelemzésig.

Kutatásomat a kis- és középvállalkozás, illetve a logisztika megközelítéseinek ismertetésével kezdtem, mely rávilágított e két fogalom sokoldalú értelmezésére. Ezt követően a KKV-k logisztikai kiszervezésétöl, a teljesítmény és e tevékenység szervezeten belüli helyére vonatkozó kutatásokon túl a stratégiai és a logisztikai eszköz szakirodalmat dolgoztam fel. Ezeket a 2. fejezet végén foglaltam össze, hogy a hipotéziseimhez iránymutatást adjanak. A disszertációm tíz hipotézisét a 4. fejezetben ismertetett módszerekkel vizsgáltam. Az eredményeket részletesen az 5. fejezet tartalmazza, melyet befejezésként külön is értékeltem. 


\section{A kis- és középvállalkozás, valamint a logisztika fogalmának értelmezése}

A fejezet célja, hogy áttekintést adjon azokról a disszertáció tárgyát képező fogalmakról, amelyekre nézve a szakirodalomban különböző irányzatok szerinti értelmezések figyelhetők meg. A fogalmakat elsősorban a kis- és középvállalkozások logisztikai szakirodalmának segítségével mutatom be.

Mindenekelőtt szükségesnek tartom a vállalkozás és a vállalat fogalmának tisztázását. „Minden olyan tevékenység vállalkozásnak tekinthető, amelyet kockázatvállalás jellemez.” (Czakó [2009] p. 9.) Ettől megkülönböztethető a nyereség elérése mellett a fogyasztói igények kielégítésének alapvető céljára irányuló tevékenységet megtestesítő üzleti vállalkozás (Chikán [2008] p. 24.), és ennek szervezeti keretét adó, jogilag önálló vállalat. E fogalmak szétválasztására számos törekvés van, mellyel kapcsolatban osztom Kállay et al. [2009] azon véleményét, hogy ezek nem különíthetők el élesen egymástól, mivel a vállalatban a vállalati és vállalkozói műveletek szétválaszthatatlanul keverednek, a vállalkozás vállalat létrehozására is irányul.

\subsection{A kis- és középvállalkozás értelmezése}

A vállalkozás méretének különböző mutatóval/mutatókkal (pl. létszám, árbevétel, beruházás, tőkésítés) meghatározott kis- és középvállalkozás fogalmát a gazdasági/üzleti életben gyakran használják. E szervezeti kört, mint az 1. táblázatban látható, világszerte másként definiálják: leggyakrabban csak a foglalkoztatottak számát használják, melyet egyes ázsiai országokban (Japán, Malajzia, Tajvan) a tőkésítettséggel együtt vizsgálnak, Indiában pedig kizárólag a beruházás méretét veszik figyelembe. 
1. táblázat: Ország-specifikus KKV meghatározások

\begin{tabular}{|c|c|c|}
\hline Ország & Iparági kategória & Kritérium vagy ország-specifikus meghatározás \\
\hline India & $\begin{array}{l}\text { Kicsi } \\
\text { Közepes } \\
\text { Kisipar }\end{array}$ & $\begin{array}{l}2,5 \text { millió rúpia üzem és gép beruházás alatt } \\
1000 \text { millió rúpia üzem és gép beruházás alatt } \\
10 \text { millió rúpia üzem és gép beruházás alatt }\end{array}$ \\
\hline Ausztrália & $\begin{array}{l}\text { Feldolgozóipari } \\
\text { szolgáltatás }\end{array}$ & $\begin{array}{l}\text { Kisvállalkozás } 20 \text { fö alatt } \\
\text { Középvállalkozás } 100 \text { fö alatt }\end{array}$ \\
\hline Kína & KKV & Termékcsoporttól függ, általában 200 fö alatt \\
\hline Franciaország & KKV & $10-499$ fö \\
\hline Indonézia & KKV & 100 fö alatt \\
\hline Japán & $\begin{array}{l}\text { Feldolgozóipar } \\
\text { Nagykereskedelem } \\
\text { Kiskereskedelem és } \\
\text { szolgáltatások }\end{array}$ & $\begin{array}{l}300 \text { fö vagy } 100 \text { millió jen tőkésítés alatt } \\
50 \text { fő vagy } 30 \text { millió jen tőkésítés alatt } \\
50 \text { fő vagy } 10 \text { millió jen tőkésítés alatt }\end{array}$ \\
\hline Dél-Korea* & $\begin{array}{l}\text { Középvállalkozás } \\
\text { Kisvállalkozás } \\
\text { Mikrovállalkozás }\end{array}$ & $\begin{array}{l}\text { ágazattól függően: } 50,100,200 \text { vagy } 300 \text { fö alatt } \\
\text { ágazattól függően: } 10 \text { vagy } 50 \text { fö alatt } \\
\text { ágazattól függően: } 5 \text { vagy } 10 \text { fő alatt }\end{array}$ \\
\hline Malajzia & $\begin{array}{l}\text { KKV } \\
\text { Kisvállalkozás } \\
\text { Közepes vállalkozás }\end{array}$ & $\begin{array}{l}75 \text { teljes munkaidős vagy } 205 \text { millió ringgit } \\
\text { részvényesi tőke alatt } \\
5-50 \text { fó vagy } 500 \text { ezer ringgit részvényesi tőke alatt } \\
50-75 \text { fő vagy } 0,5-205 \text { millió ringgit részvényesi } \\
\text { tőke }\end{array}$ \\
\hline Szingapúr & $\begin{array}{l}\text { Feldolgozóipari } \\
\text { szolgáltatások }\end{array}$ & $\begin{array}{l}12 \text { millió szingapúri dollár befektetett eszköz és } \\
100 \text { fö alatt }\end{array}$ \\
\hline Kína (Tajvan) & KKV & 40 millió új tajvani dollár tőke, vagy 200 fó alatt \\
\hline Thaiföld & $\begin{array}{l}\text { Munka-intenzív } \\
\text { ágazat } \\
\text { Tőke-intenzív ágazat }\end{array}$ & $\begin{array}{l}200 \text { fö alatt } \\
100 \text { fö alatt }\end{array}$ \\
\hline $\begin{array}{l}\text { Nagy- } \\
\text { Britannia }\end{array}$ & KKV & Nincs univerzális definíció \\
\hline $\mathbf{U S A}^{* *}$ & KKV & $\begin{array}{l}\text { ágazatfüggö, általában } 500 \text { fö és } 7 \text { millió \$ bevétel } \\
\text { alatt }\end{array}$ \\
\hline Vietnam & KKV & Általában 200 fö alatt \\
\hline
\end{tabular}

Forrás: Thakkar et al. [2009a] p. 976., módosítva: *Yang [2009], **SBA [2010] alapján

Az Európai Unióban általában az Európai Bizottság 1422/2003-as, a kis- és középvállalkozások fogalmának meghatározásáról szóló ajánlásában ${ }^{2}$ szerepelő definíciót használják, mely Magyarországon a kis- és középvállalkozásokról, fejlődésük támogatásáról szóló 2004. évi XXXIV. törvénybe is beépült. Az Európai Unióban az ajánlás alapján a következő vállalkozások tekinthetőek KKV-knak²:

\footnotetext{
2 2008-ban magasabb szintű jogforrásba, az ún. általános csoportmentességi 800/2008/EK bizottsági rendelet I. mellékletébe épült be.

${ }^{3} \mathrm{~A}$ 2. táblázatban szereplő értékek mellett nem minősül KKV-nak az a vállalkozás, amelyben az állam vagy önkormányzat közvetlen vagy közvetett tulajdoni részesedése - tőke vagy szavazati jog alapján külön-külön, vagy együttesen meghaladja a 25\%-ot.
} 
2. táblázat: A kis- és középvállalkozások Európai Unióban használt besorolása

\begin{tabular}{|c|c|c|c|}
\hline & $\begin{array}{c}\text { Foglalkoztatottak } \\
\text { száma }\end{array}$ & $\begin{array}{c}\text { Eves nettó } \\
\text { árbevétel }\end{array}$ & Mérlegfőössszeg \\
\hline Mikrovállalkozás & 10 főnél kevesebb & $\begin{array}{c}\text { legfeljebb } 2 \text { millió } \\
€\end{array}$ & legfeljebb 2 millió $€$ \\
\hline Kisvállalkozás & 10-49 fö & $\begin{array}{c}\text { legalább } 2, \\
\text { legfeljebb } 10 \\
\text { millió } €\end{array}$ & $\begin{array}{c}\text { legalább } 2 \text {, } \\
\text { legfeljebb } 10 \text { millió } \\
€\end{array}$ \\
\hline Középvállalkozás & 50-249 fö & $\begin{array}{l}\text { legalább 10, } \\
\text { legfeljebb } 50 \\
\text { millió } €\end{array}$ & $\begin{array}{c}\text { legalább 10, } \\
\text { legfeljebb } 43 \text { millió } \\
€\end{array}$ \\
\hline
\end{tabular}

Forrás: Az Európai Bizottság 1422/2003-as ajánlása alapján saját szerkesztés

A gazdálkodástudományi elemzéseknél gyakran leegyszerüsítik az Európai Unió által alkalmazott meghatározást. Egyszerü halmazelméleti ismeretekkel is belátható, hogy a leggyakrabban használt, létszámalapú kategorizálás „felülbecsüli a KKV-k súlyát és gazdasági teljesítményét a jogszabályban meghatározott teljes körü definiáláshoz képest” (Némethné [2006] p. 3.), bár „durva becslés szerint körülbelül a 250 főnél kevesebbet foglalkozó vállalkozások 1\%-nak lehet 50 millió euro feletti árbevétele”. (EIM Business \& Policy Research [2009] p. 8.) Megjegyzem, hogy a fenti jogszabályi meghatározástól eltérő definíciót több ágazatban is alkalmaznak. ${ }^{4}$

A kis- és középvállalkozások logisztikájával foglalkozó kutatásokat a KKV meghatározásaik alapján a következőképpen csoportosíthatjuk:

- Az „EU-s KKV meghatározás”, melynek az Európai Bizottság 1422/2003-as ajánlásának árbevétel (pl. finn, norvég és balti-térségi kutatások) vagy létszám korlátait követték.

- Az „észak-amerikai KKV meghatározás”, melyet leggyakrabban a foglalkoztatottak legfeljebb 500 fős száma jellemez ${ }^{5}$ (ezekre a disszertációmban saját szóhasználattal kisvállalat megnevezéssel utalok). Ebbe a kategóriába soroltam a kisvállalatokat zömmel 50 millió kanadai dollár árbevétel korláttal meghatározó kanadai kutatásokat is. (pl. Gelinas és Bigras [2004])

- Vannak olyan felmérések, melyek nem jelölik meg, hogy milyen vizsgálat alapján minősítették KKV-nek az adott vállalkozást.

\footnotetext{
${ }^{4}$ Magyarországon a pénzügyi szektorban például 100 millió Ft árbevételnél húzzák meg a határt. (Kállay és Imreh [2004] p. 32.)

${ }^{5}$ Egy Németországban végzett kutatás esetében (Uhlig és Gelinas [1994]) is ezt használták.
} 
- Az „egyéb KKV meghatározás” közé a fentiekbe nem sorolható olyan kis- és középvállalkozás definíciók került, mint:

○ A KKV-k első szisztematikus kutatásának (Kummer [1992]) létszámalapú (200 fő alatti kis, 200 és 499 fő között közepes, 500 és 999 fő között pedig nagy KKV), egyes esetekben árbevétel (20 millió DEM alatt kis, 20 és 49 millió DEM között közepes, 50 és 99 millió DEM között pedig nagy KKV) alapú besorolása.

○ Az egyes magyar elemzéseknél használt, a kis- és középvállalkozásokról szóló 1999. évi XCV. törvény szerinti meghatározása. ${ }^{6}$ (pl. Szabó [2005]; Vízhányó [2006])

○ Olyan meghatározások, amikor 200 fó és 20 millió font árbevétel alatti szervezeteket tekintettek kis- és középvállalkozásnak (pl. Quayle [2002a]) vagy a KKV-jelleget a kereskedelmi egységek számával határozták meg (Hutchinson [2009])

A kis- és középvállalkozások logisztikájával foglalkozó, a disszertáció keretében feldolgozott közel félszáz cikk és tanulmány leggyakrabban az EU-s meghatározást használta, melyet az észak-amerikai és az egyéb KKV definíció követett.

Morrissey és Pittaway [2004] a kis- és középvállalkozások beszerzését kutatva arra hívta fel a figyelmet, hogy a KKV-ket nem szabad homogén csoportként kezelni. Ezt jelzi Beumer et al. [2009] is, amikor egy 240 főt foglalkozató 50 millió $€$ forgalmú és egy 3 fös, 1 millió $€$ árbevételü KKV logisztikai koncepcióinak és megoldásainak összehasonlíthatatlanságát hozza fel példaként. Az EU-27, illetve Magyarország vállalkozásainak 3. táblázatban szereplő megoszlásából is látható, hogy utóbbiak (ti. mikrovállalkozások) vannak számszerü túlsúlyban.

\footnotetext{
${ }^{6}$ Ez az alkalmazottak száma és a tulajdonosi önállóság tekintetében nem tért el a jelenlegitől, de az árbevétel esetében 700 és 4000 millió Ft, a mérlegföösszegnél pedig 500 és 2700 millió Ft határokat állapított meg.
} 
3. táblázat: EU-27, illetve magyarországi vállalkozások száma és aránya (2010)

\begin{tabular}{|l|c|c|c|c|}
\hline & \multicolumn{2}{|c|}{ EU-27 vállalkozások } & \multicolumn{2}{c|}{ Magyarországi vállalkozások } \\
\hline & $\begin{array}{c}\text { száma } \\
\text { (ezer db) }\end{array}$ & $\begin{array}{c}\text { aránya az összes } \\
\text { vállalkozáson belül } \\
(\%)\end{array}$ & $\begin{array}{c}\text { száma } \\
\text { (ezer db) }\end{array}$ & $\begin{array}{c}\text { aránya az összes } \\
\text { vállalkozáson belül } \\
(\%)\end{array}$ \\
\hline Mikrovállalkozás & 19198,5 & $92,13 \%$ & 516,1 & $94,23 \%$ \\
\hline Kisvállalkozás & 1378,4 & $6,61 \%$ & 26,4 & $4,82 \%$ \\
\hline Középvállalkozás & 219,3 & $1,05 \%$ & 4,4 & $0,80 \%$ \\
\hline Nagyvállalat & 43,0 & $0,21 \%$ & 0,8 & $0,15 \%$ \\
\hline
\end{tabular}

Forrás: Wymenga et al. [2011] és European Commission [2011] alapján

\subsection{A logisztika tartalma}

A fegyveres erök ellátását jelentő (Kummer [1995]) logisztika a múlt század közepén került át a katonaiból a gazdasági életbe, és az I. Öböl háborúval vált mindennapos fogalommá (Tirode-Bédel [2006]). A vállalkozásoknál történő megjelenéséhez és elterjedéséhez Taylor „Tudományos menedzsmentjéből” fakadó funkcionális specializáció és a marketing fejlődése (Kummer [1995]) járult hozzá.

1. ábra: A logisztikai integráció fejlődése

60-as évek

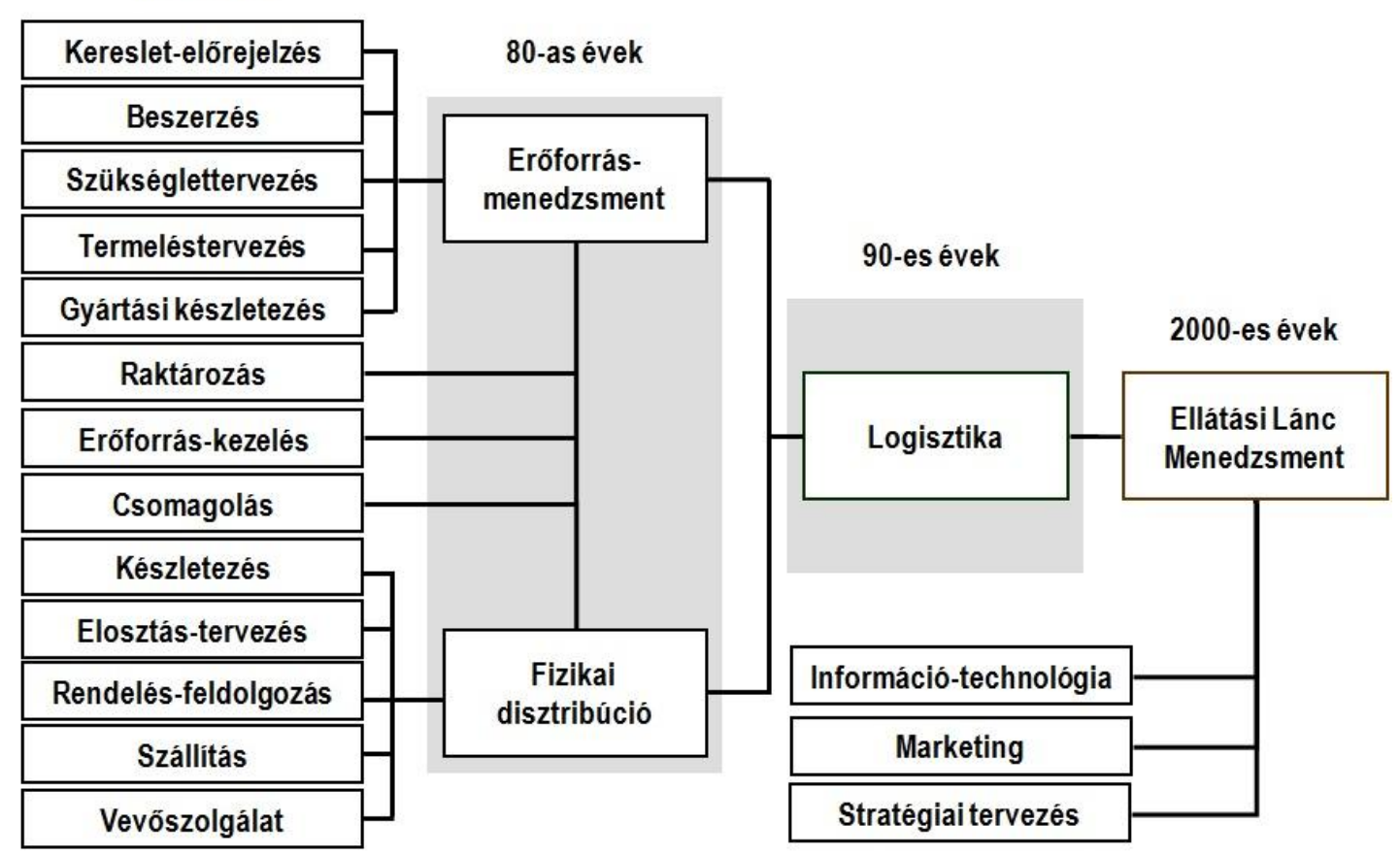

Forrás: Hesse és Rodrigue [2004] p. 175.

A logisztikai integráció 1. ábrán szereplő fejlődéséböl látható, hogy a 60-as években, amióta a termelékenységjavítás egyik kulcsaként tekintenek rá, még igen széttöredezett volt. E tevékenységek a 80-as évekre az anyaggazdálkodásba és a disztribúcióba 
olvadtak be, mely újabb integráció eredményeként a 90-es évekre a mai értelemben vett logisztika megjelenéséhez vezetett. Az ellátási láncba történő teljes integráció az ezredforduló után a modern infokommunikációs technológiákkal vált lehetővé. $\mathrm{Az}$ ellátási láncot a disszertációmban nem definiálom, csak jelzem, hogy a vállalati logisztika egyik meghatározó felmérésében - nyilván nem a leghelyesebb módon - „a logisztikát és ellátási lánc menedzsmentet gyakorlatilag szinonimaként" (Solakivi et al. [2009] p. 34.) kezelték.

A logisztika interdiszciplináris terület, mely más tudományokra, például a közgazdaságtanra, matematikára, gazdálkodástudományra, szervezetelméletre és mérnöktudományokra épül. (Klaus [2009] p. 56.) A területen végzett kutatások nehézségét az interdiszciplinaritás mellett a logisztika fogalmának többféle, egymással átfedő értelmezése okozza. A logisztika vizsgálható:

- Szállítás, tárolás, raktározás, csomagolás, rakománykezelés, szállítmányozás és kapcsolódó tevékenységekből felépülő, alapvetően a fogyasztói érték hely- és idődimenzióját befolyásoló szolgáltatásként.

- A vállalaton belüli (három fő szakasza a beszerzési, termelési és disztribúciós logisztika), illetve annak határait átlépő, az áruk áramlásához ${ }^{7}$ kötődő folyamatként vagy alrendszerként.

- Menedzsment tevékenységként vagy vállalati koordinációs funkcióként.

Logisztika felfogásom a tevékenység alapú megközelítéshez áll a legközelebb. Meggyőződésem, hogy a kis- és középvállalkozások logisztikai gyakorlatának vizsgálatára a statisztikai nómenklatúrában szereplő átfedés-mentes tevékenységosztályozás a legalkalmasabb, mivel a KKV-k e fogalmakat egységesebben értelmezik, mint a logisztikát. Ezt annak ellenére is így gondolom, hogy a magyarországi vállalatok és érdekképviseletek körében végzett interjúk kimutatták, hogy a fuvarozás, a szállítmányozás és a logisztika fogalma a piacon megfigyelhető vertikális integráció ${ }^{8}$ miatt a gyakorlatban keveredik (Bank et al. [2010] p. 46.).

\footnotetext{
7 Otto [2002] emellett megkülönbözteti az információk áramlását, az intézményi és társadalmi kapcsolatok hálózatát, Pfhol et al. [2003] pedig az értékek áramlását.

${ }^{8} 300$ magyarországi logisztikai szolgáltató körében végzett felmérés szerint a leggyakrabban a fuvarozásszállítmányozást végezték együttesen, melyet a szállítmányozás-logisztika, a fuvarozás-logisztika és a három tevékenység közös nyújtása követett. (Bank et al. [2010] p. 65.)
} 


\section{Kis- és középvállalkozásokra vonatkozó logisztikai kutatások}

A kis- és középvállalkozások logisztikájára vonatkozó kutatások feltárását elektronikus adatbázisokkal (pl. ABI/INFORM, EBSCO, Emerald, JSTOR, SciVerse) és a „szürke” irodalom magas aránya miatt a Google segítségével végeztem el. Ennek során a logisztikára és részterületeire (pl. szállítás, disztribúció), valamint a kis- és középvállalkozásokra különböző elnevezéseire és rövidítéseire (pl. SME, KMU ${ }^{9}$ ) kerestem rá. A legtöbb kutatást a „hólabda” módszerrel, azaz a meglévő cikkek irodalomjegyzékének és a szerzők egyéb kutatásai alapján sikerült megtalálnom. A kutatások megszerzése (pl. könyvtárközi kölcsönzés) mellett további nehézséget okozott, hogy azokat gyakran nem angolul publikálták (pl. németül, franciául, svédül, finnül, norvégül), emiatt a megértésükhöz különböző szoftvereket (pl. karakterfelismerő, fordító) is igénybe kellett vennem.

A kis- és középvállalkozások logisztikájának szakirodalma nem túlságosan bő, csupán kevés cikket, esettanulmányt sorolhatunk ide. Dobler [1965] beszerzési kutatását és a Castrol ausztrál kisvállalat disztribúciójának tudományos elemzését (Love és Gilmour [1976]) követően a vállalkozások logisztikájának első részletesebb tanulmányozását Heinrich és Felhofer [1985] végezte el. Azóta közel félszáz cikk, tanulmány született a témában, de a logisztikai kutatások zöme továbbra is a nagyvállalatok logisztikáját vizsgálja. Ennek oka az, hogy a nagyvállalatok logisztikai funkciói megalapozottabbak és azok jobban kutathatók. Emellett a KKV-k kutatói egyéb funkcionális részterületekre fordítják a figyelmüket, például a marketingre, a termelésre, a stratégiára és a finanszírozásra. (Pearson és Semeijn [1999]) A logisztika többi területeihez képest a KKV-k beszerzése viszonylag jól kutatott, bár Ellegaard [2006] szerint a külső erőforrásoktól való felismert függőség ellenére még mindig csak korlátozott mértékben. Ellegaard [2006] 76 kis- és középvállalkozások beszerzésével foglalkozó cikket témánként csoportosított. E szerint a legnagyobb arányban a beszállítói kapcsolatok menedzsmentjével foglalkozó cikkek jelentek meg, melyet a hálózati struktúra menedzsment, az általános, a beszerzési struktúra, a termék/folyamatfejlesztési, a tárgyalási és szerződési, illetve a beszállítói teljesítménymérési cikkek követtek.

\footnotetext{
${ }^{9}$ A KKV-k angol (Small and medium-sized enterprise), illetve német rövidítése.
} 
A KKV-k logisztikája eddig a szakmai konferenciákon is viszonylag kevés figyelmet kapott, bár Ausztriában 2005-óta tartanak kis- és középvállalkozói logisztikai napokat, a német logisztikai szövetség (BVL) pedig 2007-től rendezi meg a mannheimi KKV fórumot és a témakör súlyát felismerve kis- és középvállalkozási logisztikai bizottságot is létrehozott. Utóbbi eredményeként született esettanulmány-könyv szerzői szerint „a KKV-k logisztikája kapcsán a tulajdon(os)t kellene megkülönböztető jellemzőként alkalmazni”. A szerzők szerint azért, mert ,a tőke és a menedzsment a vállalkozó kezében van”, ő „vállalja a kockázatot és felelősséget”, a „struktúrát a személyes jelenlétével a legapróbb részletekig meghatározza”; a „vállalkozás pedig a család alapvető megélhetése” és ,bevétele”, a „vállalkozás egyfajta állandó küldetés”. (Beumer et al. [2009] pp. 2-3.). E megközelítés legfőbb problémája, hogy az esttanulmányokban szereplő családi vállalkozások ${ }^{10}$ a mutatóik alapján egy-két kivétellel mind nagyvállalatok voltak.

Az eddig kutatások elsősorban a kis- és közepes feldolgozóipari, kereskedelmi és/vagy logisztikai szolgáltató, és közülük is főként a nagyobb méretü vállalkozásokat vizsgálták. A relatív kis mintájú, nem reprezentatív, és nagyvállatokat is tartalmazó, egymástól elszigetelt keresztmetszeti felmérések, esettanulmányok eredményei nehezen összehasonlíthatóak. Néha több volt bennük a hipotézis, mint az empíria.

Jelen fejezet a kis- és középvállalkozások logisztikájára vonatkozó kutatásokat ismerteti a logisztika értelmezésétől, kiszervezési, teljesítmény (pl. költség), e funkció vállalaton belüli helyét érintő kérdésekig. Emellett a kutatásomhoz szorosan nem kötődő, de a KKV-k logisztikai gyakorlatának teljes megismeréséhez szükséges a logisztikai stratégiákra és eszközökre vonatkozó kutatásokat is feltártam. A fent említett területek általános logisztikai szakirodalma a bemutatottnál lényegesen bővebb, melyekből terjedelmi okokból csak röviden és elsősorban a hipotéziseimhez kötődő kutatásokkal foglalkoztam.

\subsection{Logisztika értelmezése és jelentősége a KKV-k esetében}

La Londe szerint a kisvállalatoknak először meg kell tanítani, hogy mi a logisztika, mivel a nagyokkal ellentétben nem tudják, hogy például mi az a ciklusidő. (idézi

\footnotetext{
10 „A család a tulajdonjog több mint 50\%-át birtokolja, és a család a vállalkozás menedzsmentjében és stratégiai irányának meghatározásában részt vesz.” (Beumer et al. [2009] p. 3.).
} 
Harrington [1995] p. 57.) A kis- és középvállalkozások logisztika értelmezését a legtöbb kutatás sajnos nem vizsgálja, pedig vélhetően nagyon eltérő megközelítések jelennek meg és ez kihat a vizsgálatok tartalmi érvényességére. Az értelmezésbeli heterogenitást mutatja 27 magyarországi termelő kis- és középvállalkozás mélyinterjús megkérdezésével készített terhelési diagram. A kutatással szintén felmért 29 kereskedő a termelőknél ugyan homogénebb felfogást mutatott, de ott is háromféle csoport volt elkülöníthető. (Szabó [2005])

2. ábra: A logisztikai folyamat kezdete és vége a magyar termelő KKV-knál

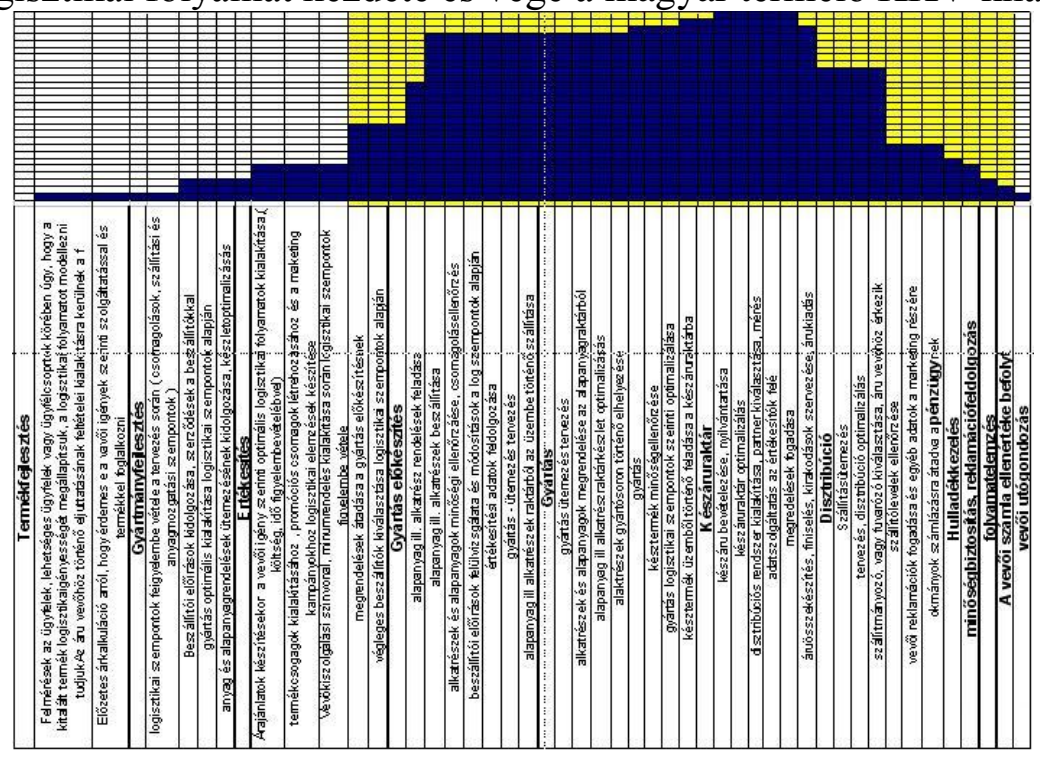

Forrás: Szabó [2005] p. 17.

A Vízhányó [2006] által vizsgált KKV-k 90\%-a logisztika alatt csak szállítást és raktározást értett, 55\%-uk a folyamat kezdetének beszerzést, végének a vevői kiszállítást tekintette. A logisztika értelmezését részletesebben a koblenzi és a dortmundi kereskedelmi és iparkamarák $111^{11}$ kereskedelmi, fémfeldolgozó, élelmiszer és italgyártó, valamint építőipari tagját felmérő kutatásban vizsgálta Kummer [1992] és az alábbi következtetésekre jutott:

- A KKV-k többségének átfogó logisztika értelmezése volt, a nagyvállalatok azonban szélesebb, a vállalati határokon is túlnyúló, összehangoló funkcióként tekintettek rá.

- A kis KKV-k logisztika felfogása relatíve homogén, a közepes és nagy KKV-ké heterogén volt, míg a nagyvállalatok uniformizáltabb megközelítéssel rendelkeztek.

${ }^{11} 38$ kis KKV, 42 közepes KKV, 16 nagy KKV és 15 nagyvállalat. 
- Az élelmiszer- és italgyártó vállalkozások homogénebb felfogással rendelkeztek, melynek hátterében Kummer [1995] a disztribúció jelentős szerepét feltételezte. Az építőiparban számottevő volt az inhomogenitás. Az iparági eltérések zömmel a logisztika különböző ismeretének és megvalósításának, illetve az iparágak eltérő anyag- és információáramlási komplexitásának volt köszönhető. Az élelmiszer- és italgyártásnál például a disztribúciónál a beszerzés és a termelés kevésbé volt komplex, a fémfeldolgozásban pedig a termelési logisztika volt a meghatározó, míg a disztribúció kevesebb figyelmet kapott.

- A logisztika elméleti fontossága és tényleges megvalósítása közti legnagyobb különbség a közepes KKV-k, míg a legkisebb a nagyvállalatok esetében volt.

- A vállalatcsoporthoz tartozásnak, a tulajdonos és menedzser szerep egybeesésének, illetve a logisztikai szakmai szervezeti tagságnak a logisztika értelmezésében nem volt szerepe.

A 4. táblázatban szereplő, a logisztika funkcionális értelmezése és a vállalatméret összefüggését mérő kontingencia együtthatók 10\%-os szinten három, 5\%-ban pedig csak egy esetben voltak szignifikánsnak tekinthetők. (Kummer [1995]) 
4. táblázat: Német vállalatok logisztika értelmezése méret szerinti bontásban ${ }^{12}$

\begin{tabular}{|c|c|c|c|c|c|c|}
\hline \multirow[b]{2}{*}{ Logisztika funkcionális értelmezése } & \multicolumn{4}{|c|}{$\begin{array}{c}\text { Átlagos alkalmazotti } \\
\text { létszám }\end{array}$} & \multirow{2}{*}{ סْ } & \multirow{2}{*}{ 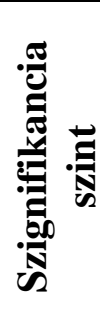 } \\
\hline & $\frac{i}{\partial}$ & 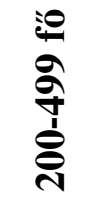 & $\frac{\rho}{\stackrel{\circ}{\sigma}}$ & 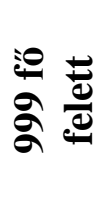 & & \\
\hline $\begin{array}{l}\text { A logisztika más keresztfunkciós } \\
\text { területekhez hasonlóan egy összehangoló } \\
\text { funkció }\end{array}$ & 1,80 & 1,90 & 2,20 & 1,40 & 0,45 & 0,10 \\
\hline $\begin{array}{l}\text { A logisztika a vállalati határokon túl is } \\
\text { koordinálni } \\
\text { folyamatokat }\end{array}$ & 2,12 & 1,70 & 2,00 & 1,33 & 0,47 & 0,05 \\
\hline $\begin{array}{l}\text { A logisztikának kellene az anyag- és az azt } \\
\text { megelőző, kísérő vagy követő } \\
\text { információáramlást kontrollálnia }\end{array}$ & 2,00 & 2,00 & 2,27 & 1,67 & 0,38 & 0,42 \\
\hline $\begin{array}{l}\text { A rendelés-feladás és -feldolgozás nem } \\
\text { része a logisztikai feladatoknak }\end{array}$ & 3,36 & 3,84 & 3,00 & 3,33 & 0,36 & 0,53 \\
\hline $\begin{array}{l}\text { A stratégiai üzleti tervezésen belül } \\
\text { független logisztikai tervezés szükséges }\end{array}$ & 2,28 & 2,35 & 2,56 & 2,50 & 0,36 & 0,25 \\
\hline $\begin{array}{l}\text { A stratégiai üzleti tervezésben a logisztika } \\
\text { csak egy kis probléma }\end{array}$ & 3,03 & 2,66 & 3,00 & 3,60 & 0,45 & 0,10 \\
\hline 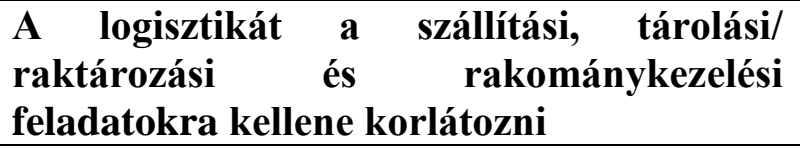 & 2,89 & 3,23 & 3,44 & 3,73 & 0,39 & 0,36 \\
\hline $\begin{array}{l}\text { A logisztikának a rövid-távú } \\
\text { menedzsmentet kellene folytatnia (pl. } \\
\text { menedzsment funkciók más területekrổ) }\end{array}$ & 2,12 & 2,83 & 2,56 & 3,07 & 0,40 & 0,28 \\
\hline $\begin{array}{l}\text { A logisztikai koncepció célja a logisztikai } \\
\text { folyamatok költségeinek minimalizálása }\end{array}$ & 2,53 & 2,84 & 3,00 & 3,43 & 0,41 & 0,25 \\
\hline
\end{tabular}

Forrás: Kummer [1995] p. 46.

A logisztikai feladatok iránti intenzívebb elkötelezettséghez Heinrich és Felhofer [1985] szerint a kereslet nagyobb változásai, bizonytalansága és a rövidebb kiszállítási idők vezetnek. Az értelmezéssel ellentétben a logisztika jelentőségét a kutatások egy része valamilyen szinten vizsgálja. A legtöbb esetben a válaszadók fontosnak tartják a logisztikát, és a zömmel Likert-skálás kérdésfeltevésnél nagy jelentőséget tulajdonítanak neki (Berr et al. [1990]; Kummer [1995]; Szabó [2005]; Vízhányó [2006]). A finn Közlekedési és Távközlési Minisztérium által 1993-tól végeztetett logisztikai felmérések a logisztika jelentőségét ennél szofisztikáltabban vizsgálták. A 2006-os felmérés feltárta, hogy a közepes és kisebb vállalkozások tisztában vannak a logisztika jelentőségével, de fejlesztési lehetőségeik korlátozottak. (Naula et al. [2006])

\footnotetext{
${ }^{12}$ Ötfokozatú ( 1 teljesen egyetért ... 5 egyáltalán nem ért egyet) skála átlagai.
} 
2008-ban a finn nagyvállalatok és a középvállalkozások a logisztika szerepét fontosabbnak tartották, mint a mikro- és kisvállalkozások (mkv). Ezt a kutatók jelentős részben a vállalatméret növekedésével járó egyre komplexebb ellátási lánccal magyarázták. A négy vizsgált elem közül a logisztika a legnagyobb hatással a vevőkiszolgálási színvonalra volt, melynek rossz menedzselését vállalatmérettől függetlenül érzékelték a cégek. A legnagyobb különbséget a nagyvállalatok és a mikrovállalkozások között a logisztika profitabilitásra gyakorolt hatásában találták. (Solakivi et al. [2009])

3. ábra: A logisztikai jelentősége a finn feldolgozóipari és kereskedelmi vállalkozásoknál

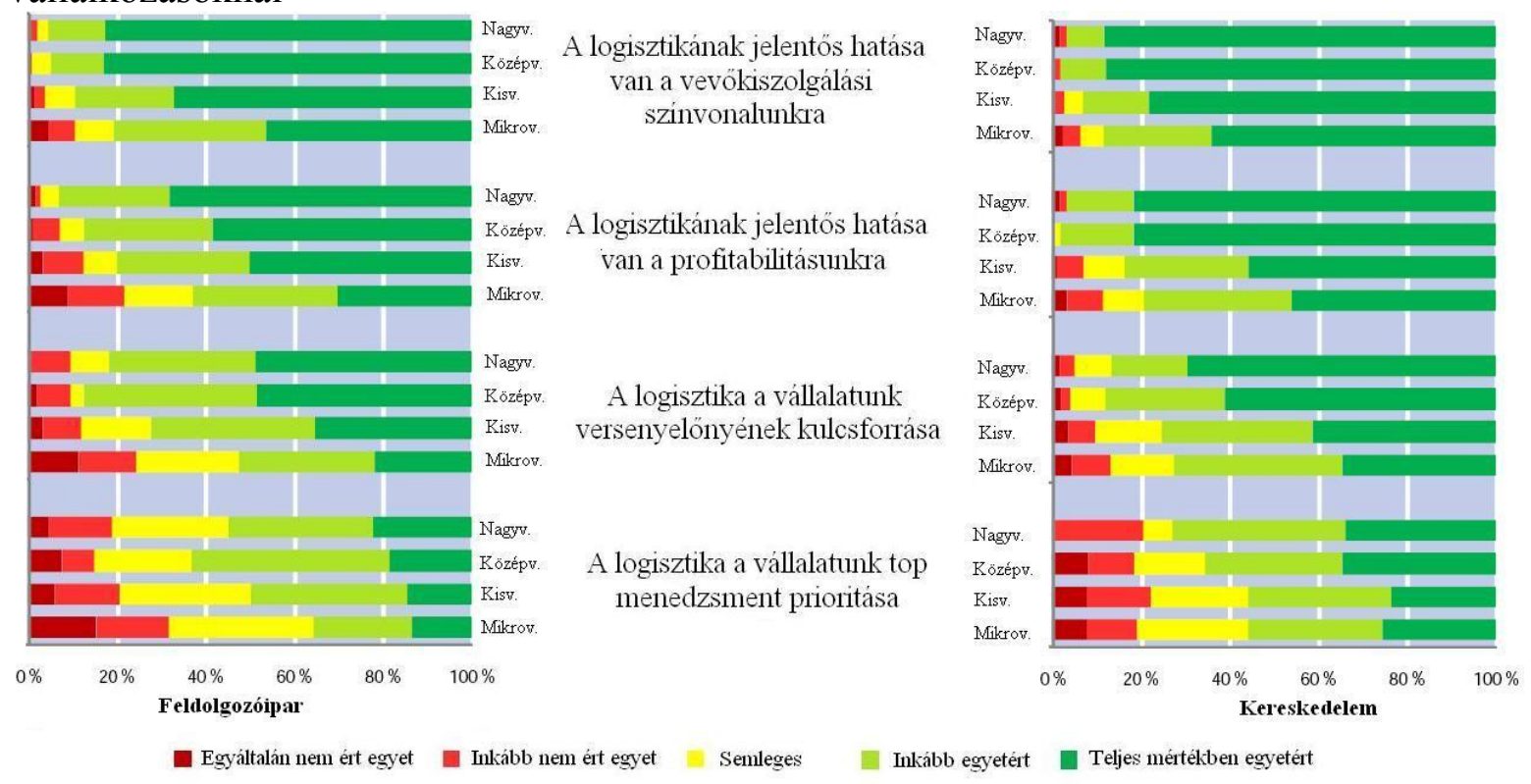

Forrás: Solakivi et al. [2009] pp. 55-56.

A KKV-k beszerzését vizsgáló cikkek is érintik a terület jelentőségének kérdését és ellentmondásos eredményekre jutnak. Quayle [2002b] azt találta, hogy a 232 általa vizsgált KKV 65\%-a nem tartotta fontosnak a beszerzést. A vizsgált kisvállalkozások a 19 funkcióból csak a 14. helyre sorolták a beszerzést. „Az általános nézet az, hogy kicsi vagy nem létező vásárlóerővel pótlólagos, amúgy is ritka erőforrásokkal nincs szükség ilyen tevékenységet folytatni”. (Quayle [2002b] p. 155.) Ugyanilyen alacsony beszerzési prioritást talált (Quayle [2002a]) 298 brit KKV e-kereskedelmét kutatva. Quayle tanulmányaihoz szorosan kapcsolódó Vörösmarty et al. [2010] kutatásában vizsgált 76 kis- és középvállalkozás húszból az 5. helyre sorolta a beszerzést. 
Egyes kutatások azt a vállalkozásméretet is meg próbálják határozni, ami felett a KKVk tudatosan kezdenek el foglalkozni a logisztikával:

- A Norvég Kutatási Tanács közlekedési kutatócsoportja 1994-ben a KKV-k logisztikai felkészültségét vizsgálta, mely megmutatta, hogy a 20 alkalmazott feletti vállalkozások logisztikája jobb a kisebbekénél. (Virum [1994])

- A német vállalkozások körében végzett korábbi felmérés szerint 200 fö alatt nem tekintik sürgősnek a különböző részlegek közötti koordinációt és az anyag-, illetve információáramlás összekapcsolását, így szisztematikusan irányított logisztikai menedzsment sincs. (Kummer [1995])

- Gritsch [2001] disszertációjában a „Versenyben a világgal” kutatás adatai alapján többek között az alábbi hipotézisekre részben megerősítést talált:

○ „A logisztikai integráció (a logisztikai jellegü - logisztikai szolgáltató és kereskedelmi - vállalatokat kivéve) a vállalatfejlődés egy jól azonosítható szakaszában valósul meg.” (Gritsch [2001] p. 50.)

○ „A vállalat akkor kezd el logisztikával foglalkozni, amikor a külső körülmények ezt kikényszerítik vagy a vállalati méret megteremti a logisztikai költségcsökkentés lehetőségét.” (Gritsch [2001] p. 50.)

- Vízhányó [2006] szakdolgozatában kérdőíves felmérés alapján azt állapította meg, hogy a kis- és középvállalkozások 1,5 milliárd Ft árbevétel felett foglalkoznak tudatosan a logisztikával.

Összefoglalásként elmondható, hogy a szakirodalomban a szerzők többsége nem vizsgálta a KKV-k logisztika értelmezését, azonban egyes kutatások (Kummer [1995]; Szabó [2005]; Vízhányó [2006]) rámutattak, hogy az valójában nem egységes. A logisztikát a KKV-k fontosnak tartották (Berr et al. [1990]; Kummer [1995]; Szabó [2005]; Vízhányó [2006]; Solakivi et al. [2009]; Vörösmarty et al. [2010]), bár egyes beszerzési kutatások (Quayle [2002a]; Quayle [2002b]) ennek ellentmondtak. A felmérések nem adtak egyértelmű választ arra, hogy a kis- és középvállalkozások milyen vállalkozásméret felett kezdenek (tudatosan) foglalkozni a logisztikával. (Virum [1994]; Kummer [1995]; Gritsch [2001]; Vízhányó [2006]) 


\subsection{Logisztikai tevékenységkiszervezés}

A tevékenységkiszervezésre (outsourcing) nincs egységes meghatározás, szükebb értelemben „a már meglévő, korábban a vállalaton, illetve intézményen belül ellátott feladatok, funkciók és a hozzájuk tartozó eszközök, berendezések, illetve kapacitások kihelyezését, külső szolgáltatókra bízását" (Szabó [1998] p. 138.) értik alatta. A logisztikai outsourcingra több szinonimát is használnak (Ivanaj és Masson Franzil [2006]; Selviaridis és Spring [2007]): a 3PL-t, a szerződéses logisztikát, a logisztikai szövetségeket vagy korábban az alvállalkozásba adást.

A logisztikai tevékenységkiszervezéssel foglalkozó cikkek többsége az elméleti hátteret $^{13}$ (Selviaridis és Spring [2007]) nem vizsgálta, ha mégis, akkor leggyakrabban a tranzakciós költség, és a(z) (alapvető) képességek, ritkábban más elméletek (pl. ügynök, játékelmélet) merültek fel lehetséges magyarázatként. (Ivanaj és Masson Franzil [2006])

A Coase [1937] nyomán Williamson [1975] által kidolgozott tranzakciós költség elmélet a neoklasszikus mikroökonómiára és a szervezetelmélet szintézisére épülő új intézményi közgazdaságtan egyik irányzata. A tranzakciós költség elmélet szerint a folyamat résztvevői korlátozott racionalitással bírnak, opportunisták és kockázatsemlegesek. Az áru vagy szolgáltatás tulajdonjog átruházás (tranzakció) költségei a folyamat lebonyolításakor és megszervezésekor merülnek fel (pl. információszerzés, tárgyalás, ellenőrzés, megállapodás értelmezési, módosítási költségei), mely a termelési költségekkel együtt a tranzakció-specifikus beruházásoktól, a bizonytalanságtól és a tranzakciók gyakoriságától függ.

5. táblázat: A tranzakciók jellemzőinek költségvonzatai

\begin{tabular}{|l|c|c|c|}
\hline & $\begin{array}{c}\text { Tranzakció-specifikus } \\
\text { beruházások }\end{array}$ & Bizonytalanság & Gyakoriság \\
\hline Transzformációs költségek & - & 0 & - \\
\hline Tranzakciós költségek & + & + & - \\
\hline
\end{tabular}

(+: növekedés; 0: nincs befolyás; -: csökkenés)

Forrás: Kieser [1995] p. 289.

\footnotetext{
${ }^{13}$ Selviaridis és Spring [2007] által vizsgált 114 logisztikai tevékenységkiszervezési cikk 69\%-a csak az iparági trendeket mutatta be, melyhez semmilyen elméleti hátteret sem kapcsoltak.
} 
A saját előállítás és a külső beszerzés (make or buy ${ }^{14}$ ) közötti választás okaira a tranzakciós költség elmélet az alábbi magyarázatot adja:

- „Ha a tranzakciók nem járnak különleges bizonytalansággal vagy tranzakcióspecifikus beruházással, a piac a legelőnyösebb intézményi megoldás.” (Kieser [1995] p. 298.)

- „Minél nehezebb és költségesebb a neoklasszikus cserekapcsolatok minden véletlenszerüségét figyelembe venni, és minél nagyobbak lesznek az esetleges nyereségek, ..., annál vonzóbb lesz a javak és szolgáltatások szervezeten belüli előállítása.” (Kieser, [1995] p. 300.)

A logisztikai tevékenységkiszervezés és a tranzakciós költség elmélet kapcsolódását eddig kevesen vizsgálták. Ivanaj és Masson Franzil [2006] szerint a logisztikai tevékenység néha tranzakció-specifikus beruházásokat (pl. hütőházak, speciális targoncák) igényel. Ennek szintje a standardizálással csökken, igaz még a napjainkban leginkább egységesített szállítás (Kotabe és Mol [2009]) és raktározás (Skjøtt-Larsen [2000]) is csak a közepes mértékben kiszervezhető. Aertsen [1993] szerint a magas eszköz-specifikusság a teljesítménymérési nehézségekkel párosulva saját disztribúcióhoz kellene, hogy vezessen. Maltz [1994] a magas eszköz-specifikusságot a saját raktározással, a tranzakciók magas számát pedig e tevékenység kiszervezésével kapcsolta össze. Skjøtt-Larsen [2000] az eszköz-specifikusságot összekapcsolta a bizonytalansággal, mely Dornier és Fender [2001] szerint a logisztika esetében az intézményi és szabályozási környezet komplexebbé válásával és a globalizáció miatt nő, és e folyamat a hagyományos logisztikai rendszereket is megváltoztatta. (pl. relokáció, késleltetés és JIT). A KKV-k körében az outsourcing alacsony szintü, melynek hátterében az igénybe venni szándékozott szolgáltatások méretgazdaságtalansági okok miatt túl magas relatív tranzakciós költsége áll, emellett az egyes szolgáltatások minimális tranzakciós mérete eltér. (Kállay és Imreh [2004]) Ugyanerre jutott van den Berg [2009], aki szerint az outsourcing hagyományos modellje a méretgazdaságosság miatt a nagy volumenekre lett kialakítva, de az infokommunikációs technológiák fejlődésével a KKV-k számára is kezd elérhetővé válni.

\footnotetext{
${ }^{14}$ Maltz és Ellram [1997] szerint az outsourcing a klasszikus make or buy egyik formája.
} 
Az erőforrás-elmélet részét képző alapvető képességek Hamel és Prahalad [1990] szerint lehetővé teszik, hogy a vállalat a különböző piaci szegmensekben képes legyen megjelenni és sikeresen helytállni a versenyben. Az értékes, ritka, nehezen másolható és szervezeti beágyazottsággal rendelkező képességek több, akár önmagában is bonyolult erőforrásból és részképességböl épülnek fel. Gelei [2007] szerint a szakirodalom jelentős része a képességek fogalmát nem használja konzekvensen, keveredik bennünk az output, illetve az input oldalról történő megközelítés. A logisztika alapvető képesség létét csak kevesen vizsgálták és ellentmondásos eredményekre jutottak. Sheffi [1990] a vállalat alapvető képességének részének tartotta a logisztikát. Halley és Guilhon [1997] szerint is a (mezőgazdasági és élelmiszeripari) kisvállalatok alapvető tevékenységének tünik a logisztika. Olavarieta és Ellinger [1997] az erőforrás alapú stratégiaszemlélet alapján azt találta, hogy a logisztikai képességek a vállalat számára nehezen másolhatók, értékesek és ritkák, azaz alapvetőek lehetnek. Fine és Whitney [1996] szerint maga az outsourcing folyamatok menedzsmentje alapvető képességnek számít. Ezekkel szemben Bentzen et al. [2000] kutatása azt erösítette meg, hogy a középvállalkozások a kiszolgáló tevékenységeket - köztük a szállítást, raktározást és készletmenedzsmentet - nem tekintik alapvető képességnek.

A logisztikai tevékenységkiszervezési kutatások az elmúlt húsz évben általában a mit, milyen mértékben és miért kérdésekre próbáltak fókuszálni, melyből csak kevés általános következtetést lehet levonni (Solakivi et al. [2011] p. 132.):

- A logisztikai outsourcing folyamatosan nőtt: Ashenbaum et al. [2005] szerint az 1996-2004-es időszakban a „Lieb sorozatok” és „Langley sorozatok” alapján a nagyvállalatoknál évente 5-8\%-kal. Razzaque és Sheng [1998] szerint ebben a fö hajtóerő a globalizáció és a technológia fejlődése volt.

- Az egyedi szolgáltatások, eredetileg főként szállítás, raktározás korlátozott mértékben komplexebb szolgáltatások irányába bővült, melyek aránya a GDP növekedésével egyre nagyobb lett. (pl. Ojala et al. [2007])

- A logisztikai tevékenységkiszervezés gyakoribb a fejlett, mint a fejlődő régiókban. (pl. Pezzotta et al. [2006])

A KKV-k logisztika tevékenységkiszervezési tanulmányai a kis- és nagyvállalati outsourcing gyakorlat összehasonlítására, a megbízó-szolgáltató kettősére épülő felmérésekre és esettanulmányokra bonthatók. Ivanaj és Masson Franzil [2006] és Hong 
et al. [2004b] ${ }^{15}$ szerint a vállalatméret, Arbaugh [2003] szerint pedig a tulajdonos/menedzser hozzáállása a logisztikai tevékenységkiszervezés egyik kontingencia-tényezője. A méret kontingencia szerepét Bardi és Tracey [1991] és az alábbi kis- és nagyvállalati gyakorlatot összehasonlító kutatások csak részben igazolták. Evans et al. [1990] kimutatták, hogy a nagy- és kisvállalatok között a feltárt 26 fuvarozó-választási szempontból 14-nél szignifikáns volt az eltérés. Utóbbiakból a kisvállalatok csak egyet (a fuvarozó múltbeli teljesítményét) minősítettek fontosnak. A kisvállalatok fuvarozási „beszerzői” választási tényezőként leggyakrabban a szállítás gyakoriságát, az átfutási időt, a károk mértékét, a hálózati lefedettséget és az árat nevezték meg.

Murphy et al. [1995] 76 amerikai, nemzetközi kereskedelembe bekapcsolódott vállalatot vizsgált. Az 6. táblázatban látható értékek tekintetében a kisvállalatok nem különböztek szignifikánsan a nagyvállalatoktól, igaz a logisztika iránt érdeklődő cégek kerültek a mintába.

6. táblázat: Nemzetközi kereskedelembe kapcsolódott amerikai kis- és nagyvállalatok logisztikai gyakorlata

\begin{tabular}{|l|c|c|c|}
\hline & Kisvállalatok & Nagyvállalatok & t-értékek \\
\hline Nemzetközi szállítmányok & $28,4 \%$ & $18,0 \%$ & 1,52 \\
\hline Vízi szállítás aránya & $55,3 \%$ & $66,7 \%$ & 0,97 \\
\hline Légi szállítás aránya & $15,6 \%$ & $25,9 \%$ & 0,99 \\
\hline $\begin{array}{l}\text { Nemzetközi szállítmányozó } \\
\text { használata }\end{array}$ & $66,9 \%$ & $70,1 \%$ & 0,29 \\
\hline NVOCC & & $24,5 \%$ & 0,84 \\
\hline Logisztikai funkciók száma & $33,2 \%$ & 5,2 & 1,00 \\
\hline
\end{tabular}

Forrás: Murphy et al. [1995] p. 11.

A felmérés szerint a nemzetközi szállítmányozók voltak a legnépszerübbek, akiket elsősorban a legnagyobb akadályként megnevezett okmánykövetelmény ${ }^{17}$ és a vám miatt vettek igénybe. A teljes forgalmuk 28,4\%-át kitevő nemzetközi szállítmányokat

\footnotetext{
${ }^{15}$ Hong et al. [2004b] azt találta, hogy az eszközérték pozitív, a létszám negatív hatást gyakorol a kínai vállalkozások kiszervezésére. Utóbbit részben a zömmel állami tulajdonú kínai nagyvállalatokkal és a fejletlen logisztikai szolgáltatói piaccal magyarázta. Hong et al. [2004a] szerint kontingenciatényező még az ágazat és a termelés típusa (JIT, tömeges testreszabás, nagy vagy kis volumenü termelés) azok, viszont a tulajdonviszonyok (állami, külföldi, közös vagy egyéb) nem.

${ }^{16}$ Fuvareszközt nem tulajdonló hajóstársaság

${ }^{17}$ Egy átlagos export-import ügylethez 40-50 különbözö dokumentum járul összesen kb. 360 másolati példánnyal. (Czakó és Reszegi szerk. [2010] p. 384.)
} 
legnagyobb mértékben vízi úton juttatták el, és meglehetősen aktívak voltak a kikötő kiválasztásában.

Murphy et al. [1999] 116 északkelet-ohiói nagy- és kisvállalat szolgáltató-választását vizsgálva arra jutott, hogy:

- A kimenő áruforgalom szállítási módjának megválasztásánál a közúti kocsirakományú, a csomag/expressz szárazföldi és a vasúti fuvarozásnál ${ }^{18}$, a bejövőnél pedig a csomag/expressz légi és a vasúti módválasztásnál volt szignifikáns a különbség a kis- és a nagyvállalatok között.

- A bejövő forgalom eredetét és a kimenő forgalmának célállomását ${ }^{19}$ tesztelve egyedül az USA-n kívüli forrás és célállomás tekintetében nem volt szignifikáns az eltérés.

- A nagyvállalatok közel kétszer annyi logisztikai szolgáltatót vettek igénybe, és e tekintetben a szállítási bróker kivételével szignifikánsan különböztek a kisvállalatoktól.

Pearson és Semeijn [1999] 301 amerikai exportőrt és importőrt vizsgálva azt találta, hogy a kis- és a nagyvállalatok logisztikai szolgáltatási jellemzőikben kevéssé különböznek. A kis-, illetve a nagyvállalatok a három legfontosabb (megbízhatóság, átfutási idő, költség), és a két legkevésbé fontos (disztribúciós szolgáltatások, raktárak) logisztikai szolgáltatási jellemző közé ugyanazokat sorolták. Szignifikáns volt az eltérés abban, hogy:

- A kisvállalatok a szállítmányozást fontosabbnak ítélték, mint a nagyvállalatok. Ezt a kutatók a nemzetközi szállítmányozásbeli tapasztalatok és az alkalmazottak hiányával, a kisebb szállítmányokkal és azok rendszertelenségével magyaráztak.

- A fuvarozói szempontok a kisvállalatok számára kevésbé voltak jelentősek, ami mögött a kisebb termelési volument és kevesebb beszállító miatti nagyobb rugalmasságot feltételezték. Az erőforrások hiánya Pearson és Semeijn [1999] szerint könnyebb fuvarozóváltáshoz vezet, a kevésbé elterjedt az éppen időben (JIT) szállítás pedig kisebb fuvarozói stabilitást igényel. Ezért a kisvállalatok a kisebb fuvarozók igénybevételére kényszerülnek.

\footnotetext{
${ }^{18}$ A kocsirakománynál kisebb közúti, a csomag/expressz légi, a légi, a vasút-közúti, a tengeri, és a belvízi szállítás tekintetében nem volt szignifikáns a különbség.

${ }^{19}$ Ohio állam, egyéb USA tagállam, és USA-n kívül kategóriák alapján
} 
- A szállítói szempontok a kisvállalatoknak kevésbé voltak fontosak, amit a kutatók a kisvállalatok saját adottságainak ismeretével, a globális fuvarozókra való kisebb igénnyel, illetve azzal magyaráztak, hogy a fuvarozókat kevésbé tudják vevőspecifikus beruházásokra sarkallni.

A nagyvállalatok és a KKV-k logisztikai kiszervezésén túl a kutatások a megbízók és a szolgáltatók együttes bevonásával próbáltak a kiszervezés mértékére és miértjeire választ keresni. McIvor [2000] a tevékenységkiszervezéshez az alábbi négylépcsős értékelési keretet állította fel, melynek:

1. lépcsőjében a szervezet alapvető és nem alapvető képességeit határozzák meg. Ha stratégiai megfontolások nem indokolják, akkor utóbbiakat kiszervezik.

2. lépcsőjében a releváns értéklánc-tevékenységeket értékelik.

3. lépcsőjében az alapvető képességek teljes költségelemzését végzik el, melynél a szolgáltatók hiánya vagy a vállalat nagyobb hozzáértése a saját tevékenységvégzéshez (annak megőrzéséhez vagy fejlesztéséhez) vezet.

4. lépcsőjében a szolgáltatói/beszállítói kapcsolatokat elemzik. Ha kellő számú, megfelelő és/vagy csekély veszélyt jelentő szolgáltató/beszállító áll rendelkezésre az a tevékenységek stratégiai kiszervezéséhez vezet. Ha nincs megfelelő szolgáltató/beszállító és/vagy kevés a veszély a jövőbeni versenyhelyzetre az saját tevékenységvégzéshez vezet.

McIvor modelljének egyik hiányossága, hogy ki nem fejtve feltételezi, hogy a fenti kimeneteken túl más esetek nem fordulnak elő. (pl. az alapvető képességnek számító tevékenységet kiszolgálni képes, de jelentős veszélyt jelentő szolgáltató nem létezik.)

A logisztikai tevékenységkiszervezés miértjeire vagy előnyeire-hátrányaira vonatkozó irodalom igen gazdag, azonban ezekre szinte csak nagyvállalatok vizsgálatából jutottak. Selviaridis és Spring [2007] szerint az okok három csoportba sorolhatók:

- A stratégiai elönyök között legtöbbször az alapvető képességek és a külső szakértelemre fókuszálás (pl. Sink és Langley [1997]) szerepel. A hátrányok között a logisztikai képesség, e tevékenység feletti ellenőrzés és a vevőkel való kapcsolatok elvesztése jelenik meg. (pl. Ellram és Cooper [1990])

- A pénzügyi előnyök között a fix költségek változóvá tétele (pl. Beumer et al. [2009]) vagy a méretgazdaságosság kiaknázása szerepel. (pl. van Damme és Ploos van Amstel [1996]) A költség-megtakarítás értékelése mindazonáltal nehéz, mivel a 
megbízó nincs mindig tisztában a logisztikai költségeivel. (lásd később a logisztikai teljesítmény fejezetnél).

- A müködési előnyöknél a készletszintek, a ciklus- és átfutási idők csökkenése és a vevőkiszolgálás javulása a fő előny (pl. Daugherty et al. [1996]), de számos hátrány is felmerül, például a szolgáltató nem megfelelő szakértelme, a vevői visszajelzések elvesztése, alkalmatlanság a speciális igények és a vészhelyzeti körülmények kezelésére (pl. Ellram és Cooper [1990]; Sink és Langley [1997])

Uhlig és Gelinas [1994] 332 német vállalat logisztikai kiszervezését vizsgálta, köztük 65 szolgáltatóét és 267 igénybevevőét. Azt találták, hogy a kisvállalatoknál leggyakrabban a szállítás, a disztribúció és a raktározás, tárolás kerül kihelyezésre, valamint a nagyvállalatok nagyobb mértékben támaszkodtak a kiszervezésre. E döntést a logisztikai outsourcingot végző vállalatok 92\%-a figyelembe vette a vállalati stratégiában, és $86 \%$-uknak előnye is származott belöle. A logisztikai outsouringot stratégiai kérdésnek és versenyelőny-forrásnak tekintették, a választásának fő indokai a költségcsökkentés, és a megnövekedett rugalmasság, elutasítása mögött pedig a függetlenség megőrzése, a stratégiai megfontolások, a túl magas költségek, a speciális szolgáltatások iránti igények, a kommunikáció és koordináció nehézsége, valamint a know-how megőrzése állt. A kis vállalatméret az utolsó helyen szerepelt az elutasítási okok között. 
4. ábra: Kiszervezni kívánt logisztikai szolgáltatások iránti kereslet német nagy- és a kisvállalatok körében

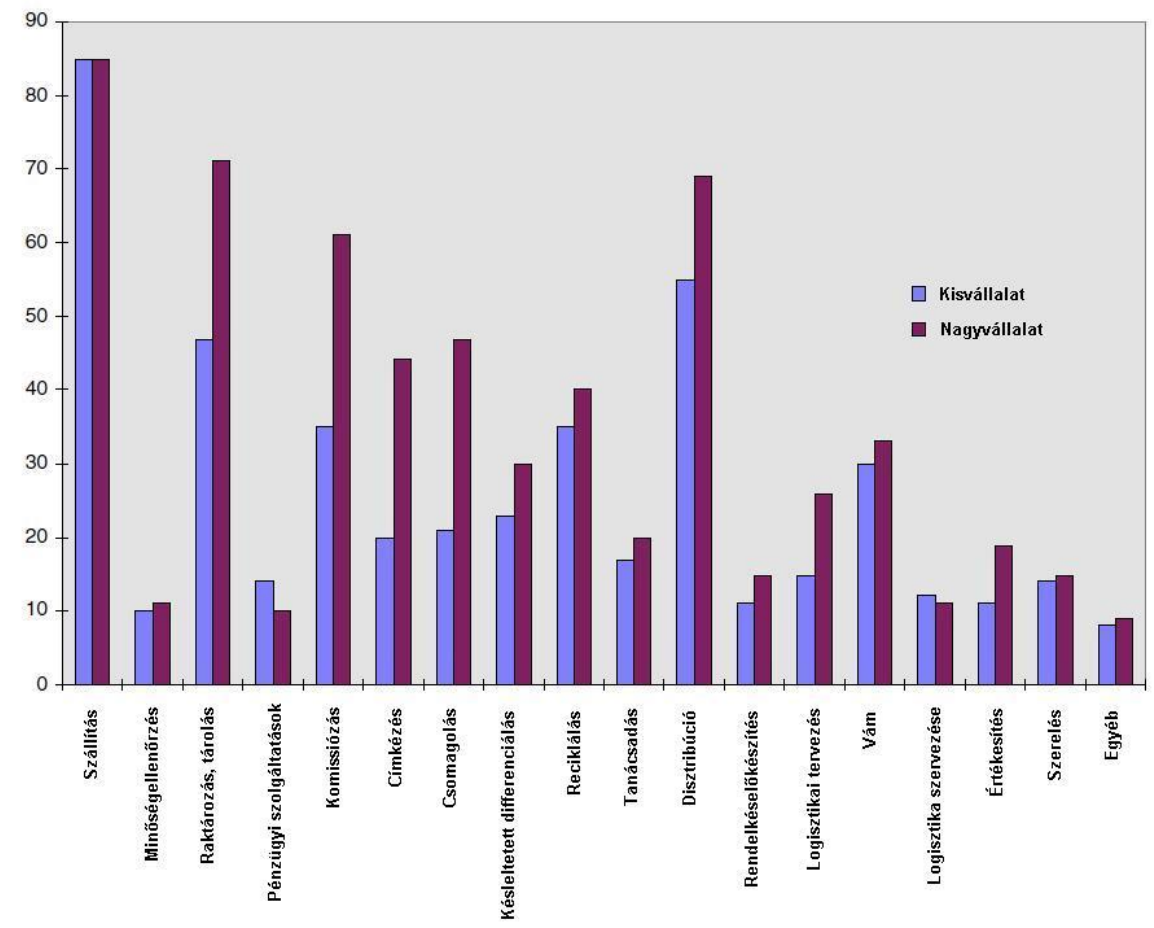

Forrás: Uhlig és Gelinas [1994] p. 734.

Gelinas és Bigras [2004] kutatásában a quebeci kisvállalatok 48\%-a, míg a nagyvállalatok 68\%-a alkalmazott logisztikai szolgáltatót. A nagyvállalatok 37\%-a állt stratégiai partnerségben a logisztikai szolgáltatókkal, míg a kisvállalatok csak 5\%-a.

A Vízhányó [2006] által felmért magyar KKV-k 67\%-a a logisztikai ousourcingról úgy vélte, hogy nem köti le a vezetői erőforrásokat, 63\%-uk szerint előnye a fö tevékenységre koncentrálás, 41\%-uk jelölt meg költségcsökkentést, 37\%-uk magasabb vevőkiszolgálási színvonalat, 30\%-uk nagyobb rugalmasságot, 26\%-uk pedig hatékonyságnövelést. A hátrányok sorrendje a folyamat feletti ellenőrzés elvesztése, a túlzott függőség, a kommunikáció hiánya okozta problémák, a müködési biztonság kockázata, a tranzakciós költségek növekedése és a pénzügyi hatások nehéz előrejelzése volt. A logisztikai tevékenységeket a 7. táblázatban látható módon végeztették, melyből a kiemelkedően magas saját raktározási tevékenységet 63\%-uk saját tulajdonú, 29\%-a bérelt és $8 \%$-uk vegyes megoldásban végezte. 
7. táblázat: Magyarországi KKV-k logisztikai tevékenységkiszervezése

\begin{tabular}{|l|c|c|c|}
\hline & Külső szolgáltatónak & Saját megoldásban & Mindkettő \\
\hline Szállítmányozás & $74 \%$ & $0 \%$ & $26 \%$ \\
\hline Belföldi fuvarozás ${ }^{\mathbf{2 0}}$ & $34 \%$ & $38 \%$ & $38 \%$ \\
\hline $\begin{array}{l}\text { Raktározás } \\
\text { komissiózás }\end{array}$ & $0 \%$ & $89 \%$ & $11 \%$ \\
\hline Vámkezelés & $46 \%$ & $37 \%$ & $17 \%$ \\
\hline Csomagolás & $17 \%$ & $71 \%$ & $12 \%$ \\
\hline
\end{tabular}

Forrás: Vízhányó [2006] p. 64.

A logisztikai szolgáltatóval szembeni elvárások között 25\%-ban a határidőre szállítás, 24\%-ban a megfelelő ár, 12\%-ban a rugalmasság, 11\%-ban a magas kiszolgálási színvonal, 9\%-ban a szakértelem, hozzáértés, 8-8\%-ban a jó partneri kapcsolat és a megfelelő technikai, technológiai háttér és 3\%-ban az ajánlott szolgáltatási csomag szerepelt. (Vízhányó [2006])

Bár nagy keresleti potenciállal rendelkeznek, és több szolgáltató így hirdeti önmagát, Kummer [1995] szerint hiányoznak a kkv-specifikus logisztikai szolgáltatások. A kisvállalatokhoz jobban illenek a kis szolgáltatók, mert agilisak, és szorosabban kötődnek hozzájuk. (Harrington [1995])

A továbbiakban öt kis- és középvállalkozás logisztikai kiszervezését bemutató esettanulmányt ismeretetek, melyek rámutatnak arra, hogy a KKV-knél a logisztikai tevékenységkiszervezésénél a költségcsökkentést gyakran egyéb okok felülírják és azt viszonylag kezdetleges módon végzik. Az idézett esettanulmányok mellett számos egyéb, elsősorban tanácsadói vagy egyetemi (szakdolgozati) magyar kutatásról is tudomásom van, melyeket bizalmas kezelésük miatt sajnos nem lehetett felhasználni.

Egy gyógyszer és diagnosztikai eszközgyártó kereskedelmi képviselőjének árui speciális kezelést, a verseny miatt pedig gyors kiszállítást igényeltek, melyet a kisvállalkozás egy magánfuvarozó és egy gyógyszer-nagykereskedő bevonásával, valamint saját tehergépkocsival is végzett. Futakfalvi [2007] a vizsgálat során arra jutott, hogy a szolgáltató árai ugyan alacsonyabbak lettek volna, de egyéb tényezők (a személyes kapcsolat a kiszállításnál, vevőkiszolgálási színvonal csökkenése, esetleges áremelés, a túrajáratos gépjárművek alacsony kapacitása) miatt nem érte meg a váltás,

${ }^{20}$ A forrásbeli értékek összege a kerekítésből fakadóan meghaladja a 100\%-ot. 
ahogyan a szállítási tevékenység egészének saját végzése sem. A vizsgálatnak eredményeként az egyik partnerrel költségcsökkentést értek el.

A Nagy [2008] által vizsgált sütőipari középvállalkozás szállítás-kiszervezésének a bizalmi viszony (a soförök gyakran kulcsot kapnak a kisebb boltokhoz, hogy az árut a nyitásra ott tudják hagyni, és az ellenértékét összegyüjtsék) volt a legnagyobb akadálya. Emellett a piacon az igényeknek (megbízhatóság, rugalmasság, folyamatos rendelkezésre állás, rövid, merev kiszállítási időablakok) megfelelő infrastruktúrával, kapcsolatrendszerrel és know-how-val rendelkező szolgáltató nem volt elérhető.

Holter et al. [2008] egy éves szinten 40\%-kal növekvő, brit fémfeldolgozó KKV-nál vizsgálták meg, hogy miként lehet a fuvarozási szolgáltatások rendelés-elfogadójából ${ }^{21}$ a rendelésadójává ${ }^{22}$ tenni. Ennek eléréséhez a vizsgálat kezdetének évében 300 konténernyi forgalmat bonyolító vállalkozás szállítási paramétereit ${ }^{23}$ elemezték. A váltáshoz a következő lépéseket tették:

- A rendszerezettebb információk a logisztikai szolgáltatók számára vonzóbbá tették a céget, mely a korábban egyesével rendelt szállítások után kedvezőbb ajánlatokat kapott.

- Az összehasonlítás érdekében egységesítették és részletezték (pl. tranzitidő) az ajánlatkérő formátumokat, melyeket egy költségmodell segítségével dolgoztak fel. Ez a menedzsment két alapvető átváltási (szolgáltatás/költség, átfutási idő/költség) döntését segítette.

- A szolgáltatási hibákra, és az eljutási időkre (pl. a késések átlagos hossza) kulcsmutatókat (KPI) készítettek, melyekhez később költségeket rendeltek.

A logisztikai szolgáltatókkal tartott rendszeres egyeztetések a szolgáltatási teljesítmény javítását eredményezték.

A Tóth [2009] által vizsgált nagykonyhai berendezésekkel kereskedő kisvállalkozás külföldi partnerektől szerezte be zömében nagyértékü és -térfogatú termékét, melynek eljuttatásához a saját árueljuttatás mellett több szolgáltatót is megbízott. A

21 A szállítási piaci versenyelőnyökből nem részesül; nem tudja, hogy kapjon versenyképes áron jó szolgáltatást. (Holter et al. [2008] p 23.)

22 A piaci körülményeket kiaknázza, versenyképes árakat kap, szolgáltatási szinteket határoz meg, proaktív, a szállítási szolgáltatás beszerzésénél bizonyos szakértelemmel bír. (Holter et al. [2008] p 23.)

23 Szállítási költségek, átfutási/eljutási idő, szállítmány nyomonkövetése, időben pontos szállítás, szállítási menedzsment költsége 
kisvállalkozásnak nehézséget jelentett a minimális exportforgalom, a speciális igények (pl. emelöhátfalas teherautó, törékeny áruk) és a csekély raktárkapacitás. A szolgáltatók minőségi problémái miatt gyakori partnerváltásokra került sor. A saját fuvareszközöknél a külföldi szállításokat kvázi körjárattal optimalizálták, de a szolgáltatásokat és az ajánlatokat részletesen nem mérték. A részletes költségelemzés azt eredményezte, hogy a külső szolgáltatók megbízása ugyan - igaz relatíve alacsony szinten ${ }^{24}$ - legfeljebb fele annyiba kerülne, mint a saját fuvareszközzel történő szállítás, de a minőségi elvárások (pl. hétvégi szállítás, megbízhatóság) miatt egyelöre az egyetlen potenciális változtatási alternatíva egy szállítmányozóval való szoros együttmüködés és a szolgáltatások jobb monitoringja volt, melyet a jövőben a fuvareszközök esetleges eladása követhetett volna. A más KKV-kel közös szállítást is vizsgálták, de ezt elvetették. (Tóth [2009])

Chao és Shah [2010] négy tajvani feldolgozóipari kisvállalkozás logisztikai kiszervezését vizsgálva megállapította, hogy egyiküknek sem volt stratégiája az outsourcing folyamatra és csak korlátozottan értették meg azt. A kiszervezést elsősorban az erőforrás- és/vagy szakértelemhiány miatt, másodsorban költségmegfontolásból végezték, célként a szállítási költségek minimalizálását és az időbeni szállítást tűzték ki. A szolgáltató formális értékelését csak egyikük végezte el, és legfeljebb egy éves szerződést kötöttek a szolgáltatókkal. A szolgáltatókkal a kapcsolatukat taktikai partnerségnek tekintették, a folyamatok folyamatos felülvizsgálatát és javítását nem végezték el.

Összegzésként elmondható, hogy a logisztikai tevékenységkiszervezésre kevés általános következtetés vonható le és a témával foglalkozó cikkek többsége nem vizsgálta az elméleti hátteret, ha mégis, akkor leggyakrabban a tranzakciós költségek és az erőforrás-elmélethez köthető (alapvető) képességek merültek fel magyarázatként. A felmérések szerint a más néven is vizsgált logisztikai tevékenységkiszervezés (pl. 3PL, szerződéses logisztika) szintje az elmúlt években folyamatosan nőtt, az egyeditől a komplexebb szolgáltatások felé mozdult el, és gyakoribb a fejlett, mint a fejlődő régiókban. Ivanaj és Masson Franzil [2006] és Hong et al. [2004b] szerint a vállalatméret a logisztikai tevékenységkiszervezés egyik kontingencia-tényezője, bár Bardi és Tracey [1991] szerint ez nem egyértelmü. A logisztikai outsourcing kutatások a

\footnotetext{
${ }^{24}$ Az adózott eredmény közel 20\%-kal javulhatna.
} 
nagyvállalatok és KKV-k között szignifikáns különbségeket találtak (Evans et al. [1990]; Murphy et al. [1999]; Gelinas és Bigras [2004]), azonban a nemzetközi kereskedelembe bekapcsolódás esetén (Murphy et al. [1995]; Pearson és Semeijn [1999]) ezek eltüntek. A KKV-k logisztikai tevékenységkiszervezését Chao és Shah [2010] szerint elsősorban taktikai, mint stratégiai szempontból végzik és a döntés melletti és elleni érvek sorrendje változatos (Uhlig és Gelinas [1994]; Vízhányó [2006]), bár egyes esettanulmányok (Futakfalvi [2007]; Nagy [2008]; Tóth [2009]) alapján a költségcsökkentési lehetőséget egyéb szempontok felülírhatják.

\subsection{Logisztikai teljesítmény}

A logisztikai teljesítmény a logisztikai „tevékenységek eredményességének értékelése, a hatékonyság (a fogyasztói igényeknek való megfelelés), illetve a gazdaságosság (az adott kiszolgálási színvonalhoz kapcsolódó erőforrás-felhasználás gazdaságossága) szempontjából”" (Chikán és Demeter szerk. [2004] 532. o. alapján), melynek feladata alapvetően a döntések támogatása. A logisztikai teljesítmény számszerüsítése, azaz mérése alapvetően pénzügyi mutatókon alapszik és több módszert is alkalmaznak rá a tevékenység alapú költségszámítástól (activity-based costing) a logisztikai értékelőtáblán $^{25}$ át az ellátási lánc modellekig. (pl. $\operatorname{SCOR}^{26}$ ). Ezek a módszerek alapvetően nagyvállalatokra készültek, bár egyeseknek KKV-s adaptációja is létezik. (pl. SCOR-nál Thakkar et al. [2009b]) Jelen alfejezet a KKV-k logisztikai teljesítményével kapcsolatos kutatásokat ismerteti, külön kiemelve a logisztikai költségekkel kapcsolatos felméréseket.

A kisvállalatok logisztikai teljesítménye Halley és Guilhon [1997] szerint több szempontból is vizsgálható:

- pénzügyi (pl. szállítási költségek, készletforgás) mutatókon keresztül nézve relatíve fejletlen és reaktív,

- szervezeti indikátorok alapján egy fejlődő tevékenység,

- értékteremtő mutatókon át egy integrált, proaktív, a kompetenciákat érintő tevékenység, mely a tulajdonos-menedzser ellenőrzését terjeszti ki.

${ }^{25}$ Logistics scoreboard, mely gyakorlatilag a Balanced Scorecard logisztikára adaptált változata: pénzügyi teljesítmény, logisztikai produktivitás (pl. kapacitáskihasználtságból), logisztikai minőség (pl. árukár) és logisztikai ciklusidő (pl. kiszállítási idő) mutatókból áll. (Frazelle [2002])

${ }^{26}$ Supply Chain Operation Reference. 
A logisztikai folyamatok állandó javításának elősegítése céljából Bagchi és Virum [2000] norvég KKV-k logisztikai teljesítményét elemezte, melynek főbb megállapításai:

- A beszállítónak adott rendeléstől annak beérkezéséig, a nyersanyagkészlet átlagos hosszától, a termelési időből, a késztermékkészletek átlagos hosszától, a vevői rendeléstől annak átvételéig és a kifizetésig tartó időszakot magába foglaló ciklusidő 81-584 napos volt és iparágon belül nagy volt a szóródás.

- A logisztikai menedzsment folyamatok javításánál a vevőkiszolgálási célok felállítása, és a logisztikai folyamatok tökéletesítésének szervezése kapott különös figyelmet. A kutatók várakozásaival ellentétben a halászati és textilipari cégek jól kezelték a logisztikájukat.

- Az eszközarányos megtérülésre gyakorolt hatást döntően a teljes logisztikai költség, a logisztikai folyamatokra fordított idő, a logisztikai folyamatok tökéletesítésének szervezése és a vevőkiszolgálási célok felállítása magyarázza.

Grando és Belvedere [2006] azt vizsgálta, hogy egy klasztertag KKV termelési és logisztikai teljesítménye jobb-e, mint egy ,függetlené”, illetve az előbbi, és a nagyvállalat közötti szakadékot át tudja-e hidalni. A klasztertag KKV-k müködési és logisztikai sebesség szempontból a legjobban teljesítettek. A kutatók megállapították, hogy a klasztertagság jelentősen erősítette a logisztikai válaszadási képességet, és bár a termékeik minősége a „független” KKV-knél jobb, de a nagyvállalatokénál rosszabb volt. A nagyvállalatok rugalmassági, termeléstervezési és minőségi, a „független” KKV-k pedig innovációs szempontból emelkedtek ki. Grando és Belvedere [2006] szerint a KKV-knek az ellátási lánc elvek terjedésével javítaniuk kell a termékminőségen és a kiszállítási megbízhatósági teljesítményen, ha a termelési hálózatban részt akarnak venni.

A finn KKV-k logisztikai és pénzügyi teljesítménye közötti kapcsolatot a „Finland State of Logistics” 2006-os ${ }^{27}$ költség, szolgáltatási szint ${ }^{28}$, és egyéb ${ }^{29}$ adatait felhasználva vizsgálták. Töyli et al. [2008] arra jutottak, hogy a vizsgált vállalkozásoknál nincs statisztikailag megfigyelhető pozitív kapcsolat a logisztikai és a pénzügyi teljesítmény között. A 2008-as adatokat elemezve hasonló eredményre jutottak, és a logisztikai

\footnotetext{
${ }^{27}$ kizárva az 5 fó alatti cégeket

${ }^{28}$ tökéletes rendelésteljesítés \%, rendelési ciklusidő

${ }^{29}$ készletszint, kintlévőségek
} 
tevékenységkiszervezés és a teljesítmény között sem találtak szignifikáns összefüggést. (Solakivi et al. [2011]) Ez azért érdekes, mivel a logisztikai irodalomban általánosan feltételezik, hogy a kiváló logisztikai teljesítmény magas pénzügyi teljesítménnyel jár, és ezt a kiskereskedelem (Schramm-Klein és Morschett [2006]), a feldolgozóiparban (Shang és Marlow [2005]), és egyéb területeken (Bagchi és Virum [2000]; Gritsch [2001]) empirikus tanulmányok is megerősítették. Részben ezt igazolták a norvég kisés középvállalkozásoknál bizonyos logisztikai elemek és a vállalat nyeresége közötti összefüggések (Lea et al. [1996]), valamint a görög KKV-knél feltárt kapcsolat is, amely megmutatta, hogy a logisztika közvetlenül befolyásolta a vállalati teljesítményt. (Orfanos et al. [2010])

A logisztikai szolgáltatási színvonal és költséghatékonyság pozitívan kapcsolódott egymáshoz, azaz a relatíve magas szolgáltatási szintü vállalkozásoknak relatív alacsony logisztikai költségei voltak. Ez Töyli et al. [2008] szerint arra utal, hogy Finnországban a KKV-k körében a logisztika csak most kezdett nagyobb figyelmet kapni.

A finn vállalkozások leggyakrabban saját valamint beszállítóik és vevőik belső logisztikai költségeit, teljesítményét, illetve ezek hasznait követték nyomon, míg a legritkábban a környezetre gyakorolt hatást, illetve a versenytársakkal való logisztikai teljesítmény benchmarkot.

5. ábra: Kulcsmutatók nyomonkövetése és használata finn vállalkozásoknál
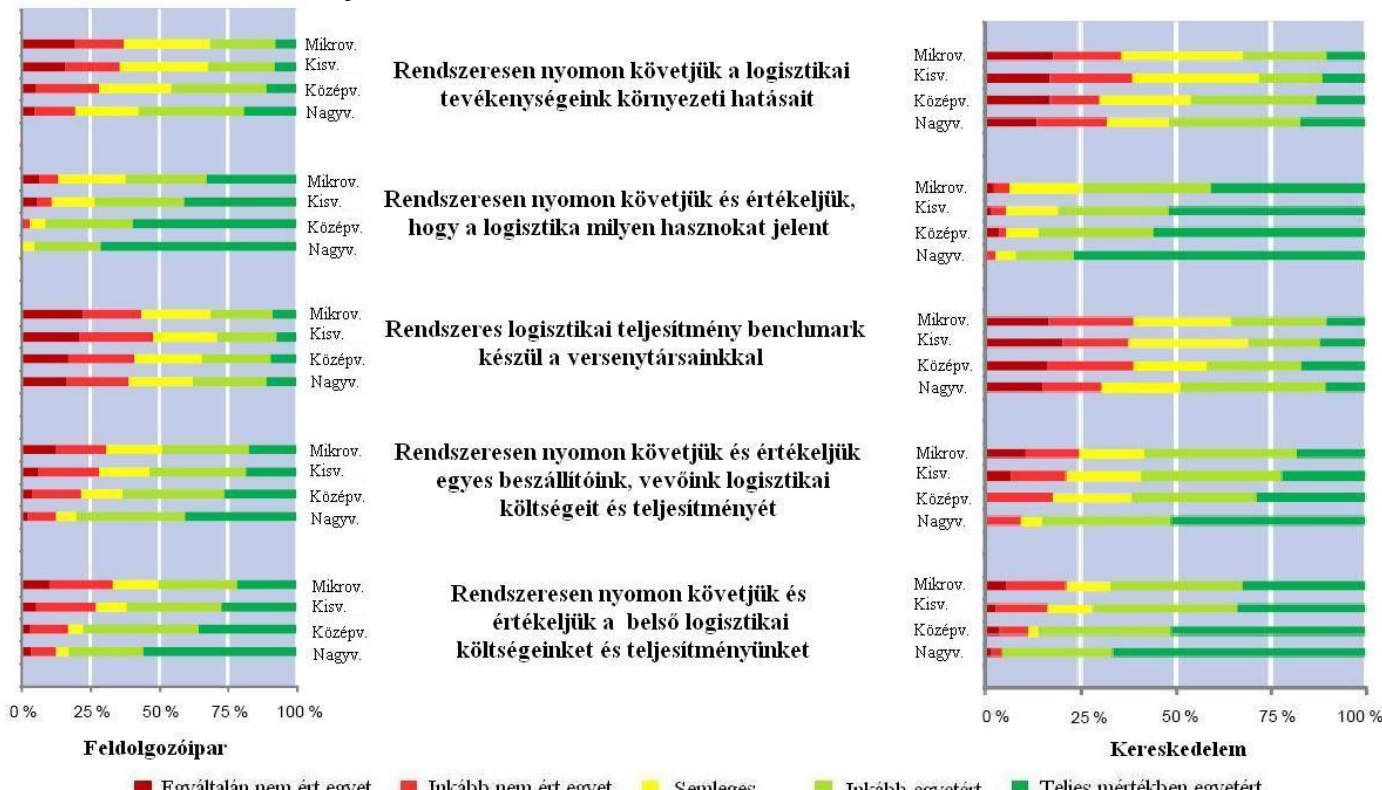

Forrás: Solakivi et al. [2009] pp. 75-76. alapján 
A kisvállalatok a korlátozott erőforrásaik miatt kevés időt szentelnek a beszerzésre, azt is annak hatékonyságának javítására fordítják, és a beszerzés fokozott tervezésével a kisvállalatok erőforrásokat szabadíthatnak fel a kreatív, nyereségtermelő tevékenységekre. (Dobler [1965]). Presutti [1988] pittsburghi feldolgozóipari kisvállalatok vizsgálatánál kimutatta, hogy $82 \%$-uk egyetértett azzal, hogy a vállalati nyereség fő forrása a beszerzési tevékenység. A Paik et al. [2009] által vizsgált dán, indianai és kaliforniai kisvállalatok közül sokan felismerték, hogy a beszerzésnek a vállalat profitabilitására jelentős hatása van, és azt hitték, hogy e funkció hatékonyságától jelentősen függnek. A kutatók szerint sok kisvállalat fogoly beszerzői pozícióban van. Paik et al. [2009] azt találták, hogy az amerikai vállalatoknál a beszerzés komplexitása ${ }^{30}$ pozitívan befolyásolja a beszerzés fejlesztését ${ }^{31}$.

\subsubsection{Logisztikai költség(szint)ek}

A logisztikai teljesítmény mérésének egyik gyakran használt mutatója a logisztikai költségszint, melyre nincs egységes definíció és gyakran tévesen a változatos viszonyítású alapú költségek, ráfordítások és kiadások szintjét szinonimaként kezelik. A logisztikai részköltségek közül elméleti szinten a szállítási költség vizsgálata emelhető ki, melyet elöször von Thünen [1826] vizsgált a mezőgazdasági termékek egyetlen piacra történő szállítása kapcsán. A szállítási költség és rajta keresztül a térszemlélet a közgazdasági gondolkodásba még a samuelsoni jéghegy elv (Samuelson [1952]) megjelenésekor sem épült be kellően, ezt csak Krugman [1991] „Növekvő hozadék és gazdaságföldrajz" cikkéért kapott Nobel-díja hozta el.

A logisztikai költségek meghatározásának két fő kutatási irányzata van: a vállalati és a makroszintü. Utóbbinál egyes országok logisztikai költségeit, kiadásait becsülik meg általában ökonometriai modellekkel (pl. Rodrigues et al. [2005] ${ }^{32}$; Klaus [2008]; Wilson [2009]; King [2010]) vagy vállalati statisztikák alapján (Elger et al. [2008])

\footnotetext{
${ }^{30}$ A beszerzett áruk és szolgáltatások teljes költségre gyakorolt hatásával, a technológiai váltás fokával és a helyettesítő források ellátásával mérték.

31 Időráfordítással, koordinációval, a beszerzési funkció meghosszabbításával, a személyzet képzettségével, a beszállító-kiválasztás módszerével, a beszerzési teljesítmény mérésével, a beszállitói kapcsolat típusaival, és a beszerzés fontosságának felismerésével mérték.

${ }^{32}$ Neurális hálón alapuló makroszintủ becslésük alapján 1997-ben Európában 12,2\%-ot, 2000-ben 12,8\%ot, 2002-ben pedig 13,3\%-ot értek el a logisztikai kiadások.
} 
A disszertációmban elsősorban a kis- és középvállalati logisztikai költségszintekkel kívánok foglalkozni, ezért ezeket a kutatásokat ismertetem részletesen.

A német finommechanikai és optikai KKV-k körében végzett kutatás szerint 42,4\%-uk logisztikai költségről nem adott számot (Berr et al. [1990]), és bár kisebb arányban, de a jelenség a mexikói feldolgozóipari kis- és középvállalkozások körében is felbukkant. (Campos-Garcia et al. [2011]) Amennyiben a logisztikai költségek a kis- és középvállalkozások körében egyáltalán tudatosulnak, akkor is csak mérsékelten vannak ezekkel tisztában (Tempel és Meißner [2002]), és ahogyan a részletesen vizsgált 30 norvég KKV esete mutatja, valamennyi elemével egyikük sem. (Virum [1994]) A kisés középvállalkozások logisztikai költségszintjei óvatosan kezelendők, mivel:

1. A költségek jelentős része becslés, melynek viszonyítási alapjai (árbevétel vagy összköltség) a kutatásokban nem egységes. A KKV-knál általában nincsenek logisztikai költséghelyek (a közepes vállalkozásoknál a jármüflotta, a készlet vagy a raktár lehet ilyen), és „a logisztikai költségeket rezsiköltségként kezelik.” (Tempel és Meißner [2002] p. 56.) A logisztikai költségek területén adathiány van (Kummer [1995]), az informatika sem mindenütt támogatja a nyilvántartásukat ${ }^{33}$, és ha nyomon is követik (lásd 5. ábra), akkor sem mindig rendszeresen.

2. A logisztikai költségkomponensek meghatározása nem egységes (pl. csomagolási költség ${ }^{34}$ ), illetve többféle megközelítésük lehetséges (pl. szállítási vs. fuvarozási költség ${ }^{35}$ ), melyet jól mutat a 8 . táblázat.

\footnotetext{
${ }^{33}$ A logisztikai költségek nyilvántartását a 2009-es Versenyben a világgal által felmért mintegy 300 vállalkozás közel felénél támogatta csak az informatika. (Chikán et al. [2010]) 48 olasz, német és magyar autóipari vállalkozás $(87,5 \%$-uk KKV) körében végzett felmérés szerint csak harmaduk mérte a logisztikai költségét. (Pezzotta et al. [2006])

${ }_{34}^{34}$ A csomagolás fogyasztói (elsődleges), gyüjtő (másodlagos), vagy szállítási (harmadlagos) lehet.

${ }^{35}$ Tartalmilag megegyezik, de ha a vállalat saját maga végzi, akkor szállítási, ha pedig külső szolgáltató, akkor fuvarozási költség.
} 
8. táblázat: Logisztikai költségek egy lehetséges felosztása

Alternatív vagy
rezsiköltségek

Funkcionális

költségek

\begin{tabular}{|c|c|}
\hline $\begin{array}{l}\text { Raktározási költségek } \\
\text { Időköltség } \\
\text { Müködési költségek }\end{array}$ & $\begin{array}{l}\text { Elvesztett eladások költsége } \\
\text { Vevőkiszolgálási szint } \\
\text { költsége } \\
\text { Piacképtelen termékek } \\
\text { költsége } \\
\text { IT-beszerzés és müködtetés } \\
\text { költsége }\end{array}$ \\
\hline $\begin{array}{c}\text { (Áru)szállítás } \\
\text { Rakománykezelés } \\
\text { Készletköltségek } \\
\text { Infrastruktúra használati díjak } \\
\text { Dokumentáció költsége } \\
\text { Közvetlen IT }\end{array}$ & $\begin{array}{c}\text { Csomagolóanyag } \\
\text { Csomagolási költség } \\
\text { Logisztikai eszközök, } \\
\text { helyszínek és tökeköltség } \\
\text { Adminisztrációs költség }\end{array}$ \\
\hline
\end{tabular}

Közvetlen logisztikai költségek

Közvetett logisztikai költségek

Forrás: Solakivi et al. [2009] p. 21.

3. A nem reprezentatív kutatások a legtöbb esetben nagyvállalati értékeket is, vagy ezekhez hasonló méretű KKV-ket tartalmaznak. Emellett a költségszintet feltételezhetően az eltérő ágazatok, a követett stratégiák, a fó értékesítési piacok, az alkalmazott INCOTERMS klauzulák ${ }^{36}$, az eltérő müködési környezet és a hatékonyság ${ }^{37}$ is befolyásolja.

Bagchi és Virum [2000] szerint a döntően európai szinten is igen versenyképes norvég vállalkozások átlagos logisztikai költsége az árbevétel kb. 10\%-át tette ki és az adott iparágon belül is jelentős volt a szóródás. A zömében alacsony árú terméket (pl. savanyított hering) forgalmazó halászati cégeknek például 14,3-16,0\%-os, míg a magas árúaknál csak 5,0\%-os volt a logisztikai költségek szintje. Tőkés [2010] a magyar textilipari cégeket vizsgálva hasonló eredményre jutott. Az exportáló norvég feldolgozóipari KKV-k körében Lea et al. [1996] azt találta, hogy a logisztikai összköltség az árbevétel emelkedésével közel azonos mértékben nő, és bár kisebb mértékben ez az inputok hozzáadott értékének emelkedésével is bekövetkezik, a készletek forgási sebességének emelkedése viszont csökkenti a mértékét. A kutatók a hosszabb exportgyakorlattal rendelkező norvég KKV-nál 5,1\%-kal kisebb, a beszállítási problémákkal küzdőknél 8,7\%-kal, a rövidtávú keresletcsökkenéssel szembesülőknél

\footnotetext{
${ }^{36} \mathrm{Ha}$ az adott vállalkozás az árukat EXW-n (gyárból) veszi, akkor a logisztikai költségei lényegesen magasabbak lesznek annál, ha ezt például DDP-n (vámfizetéssel leszállítva) teszi.

37 Az IMD [2008] szerint Magyarországon a kkv-szektor hatékonysága lényegesen alacsonyabb volt a nagyvállalatinál, Finnország esetében közel hasonló, míg például Németország esetében a kis- és középvállalkozások hatékonysága meghaladta a nagyvállalatokét.
} 
pedig 9,2\%-kal magasabb logisztikai költségeket találtak (Lea et al. [1996]) A szintén norvég vállalkozások logisztikai költségét vizsgáló Hovi és Hansen [2010] a vállalatméret (mind árbevétel, mind létszám) alapján méretgazdaságossági hatásokat talált.

6. ábra: Norvég feldolgozóipari, kereskedelmi és építőipari vállalkozások logisztikai költségszintjei 2007-ben

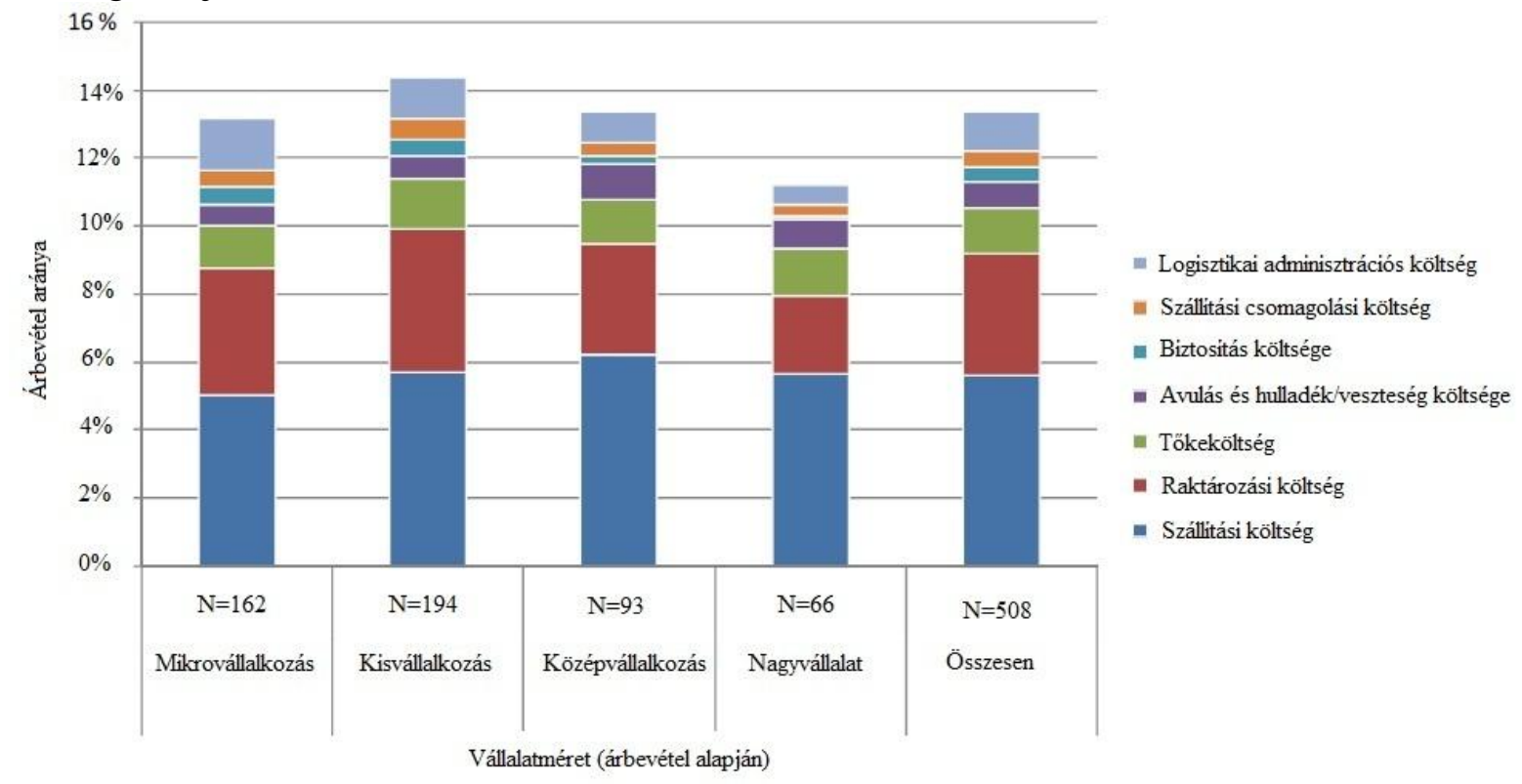

Forrás: Hovi és Hansen [2010] p. 27.

A magyarországi KKV-k logisztikai költségeinek szintjét 2004-ben átlagosan az árbevétel 12,1\%-ra becsülték (a termelőknél 11,3\%, a kereskedőknél 14,4\%, a szolgáltatóknál 10,5\%). (Szabó [2005]) Egy évvel később azt találták, hogy a kis- és középvállalkozások összköltségének átlagosan 19,18\%-a volt logisztikai költség, amely a kereskedöknél lényegesen magasabb (21,94\%) volt, mint a termelöknél (11,40\%-a). A logisztikai költségeken belül a fuvar- $(46,6 \%)$, a raktározási és a készlettartási költségek $(37,1 \%)$ voltak a meghatározóak. ${ }^{38}$ (Vízhányó [2006])

A finn vállalkozások logisztikai összköltségszintje 2009-ben átlagosan 11,9\% volt, amin belül a mikrovállalkozásoké a 2005-ös és 2008-as felmérésnél alacsonyabb, a kis- és középvállalkozásoké viszont magasabb szintű volt. A minél nagyobb a vállalat annál kisebb a költségszint hüvelykujj-szabály Solakivi et al. [2011] szerint a középvállalkozásokra nem igaz, mivel növekedésből származó költségekkel már

\footnotetext{
${ }^{38}$ A csomagolás és komissiózás $8,6 \%$, az üzemen belüli szállítás $2,4 \%$, a vám $2,1 \%$, a rendelésfeldolgozás $2,0 \%$, a szállítmánybiztosítás $0,1 \%$, az egyéb költség pedig $1,1 \%$ volt.
} 
számolniuk kell, azonban a megfelelő méretből származó előnyök kiaknázásához (pl. az ellátási láncbeli partnerekre kényszerítés) még túl kicsik. A logisztikai összköltségen belül a szállítási és a készlettartási költség volt a legjelentősebb, a KKV-k esetében utóbbit a keresletingadozás és a nagyvállalatok beszállítókkal szembeni gyakorlata is növelte. (Solakivi et al. [2010]) A 2005-ös kutatásnál az exportáló ${ }^{39}$ KKV-k logisztikai költségszintje szignifikánsan alacsonyabb volt a hazaiaknál (Naula et al. [2006]), ám ez 2008-ra ez megfordult. (Solakivi et al. [2009])

7. ábra: Finn feldolgozóipari és kereskedelmi vállalkozások logisztikai költségszintjeinek változása $(2005,2008,2009)$

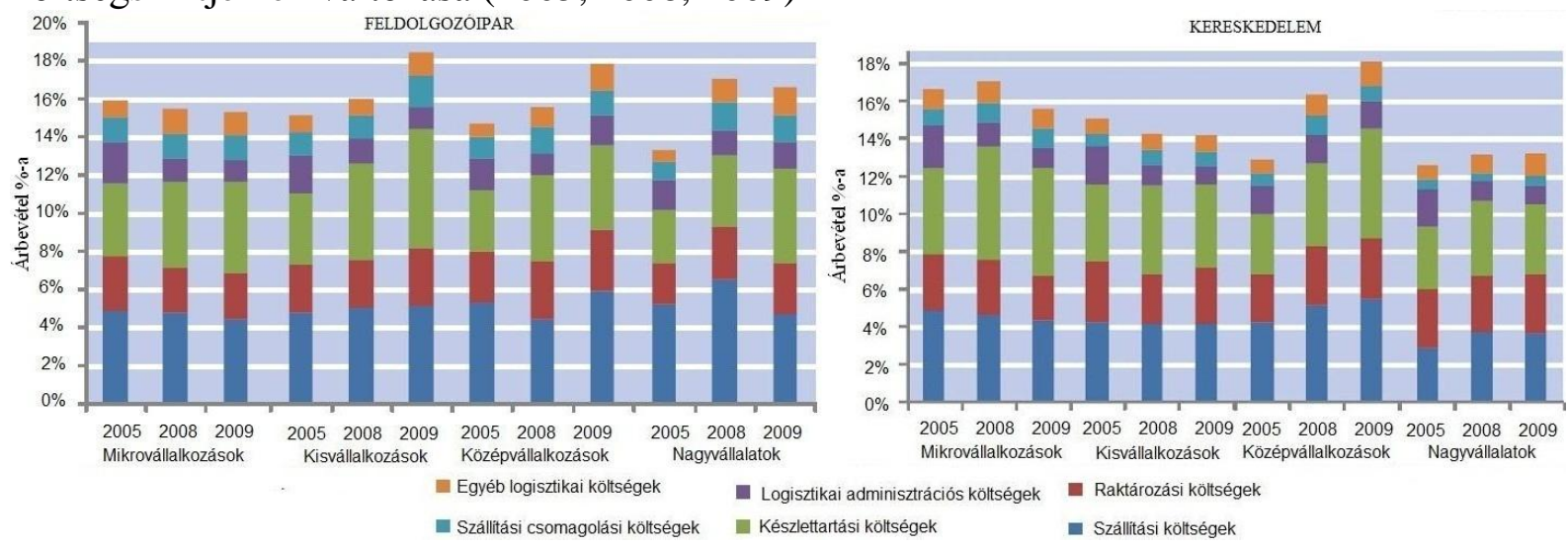

Forrás: Solakivi et al. [2010] pp. 76-77. alapján

Solakivi et al. [2011] tanulmányukban 223 finn feldolgozóipari és kereskedő KKV-t elemzett a 2008-as finn logisztikai felmérés adataiból kiindulva. A logisztikai tevékenységkiszervezés és költségek között fordított U-alakú összefüggést találtak: az összköltség és egyes részköltségek szintje enyhén alacsonyabb volt a tevékenységet egyáltalán ki nem szervezők és több mint felét kiszervezők körében, mint a köztes kategóriában. A szerzők megjegyezték, hogy a tevékenységkiszervező KKV-k jobban tisztában voltak a logisztikai költségeikkel.

A finn kutatáshoz hasonló, a balti térség nyolc országának ${ }^{40} 1234^{41}$ feldolgozóipari (és építőipari), kereskedő és logisztikai szolgáltató vállalkozás bevonásával készített felmérése a logisztikai költségek tekintetében a vállalatméret növekedésével az

\footnotetext{
39 Árbevétele legalább 10\%-a exportból származik

40 Észtország, Finnország, Lengyelország, Lettország, Litvánia, Németország, Oroszország és Svédország.

${ }^{41} 9,1 \%$-ban nagyvállalat
} 
árbevétel arányában mért logisztikai összköltség csökkenését ${ }^{42}$, és a feldolgozóiparban a földrajzi elhelyezkedéstől való függetlenséget találták. (Ojala et al. [2007])

8. ábra: Balti-tengeri térségi vállalkozások logisztikai költségszintjei 2006-2007-ben

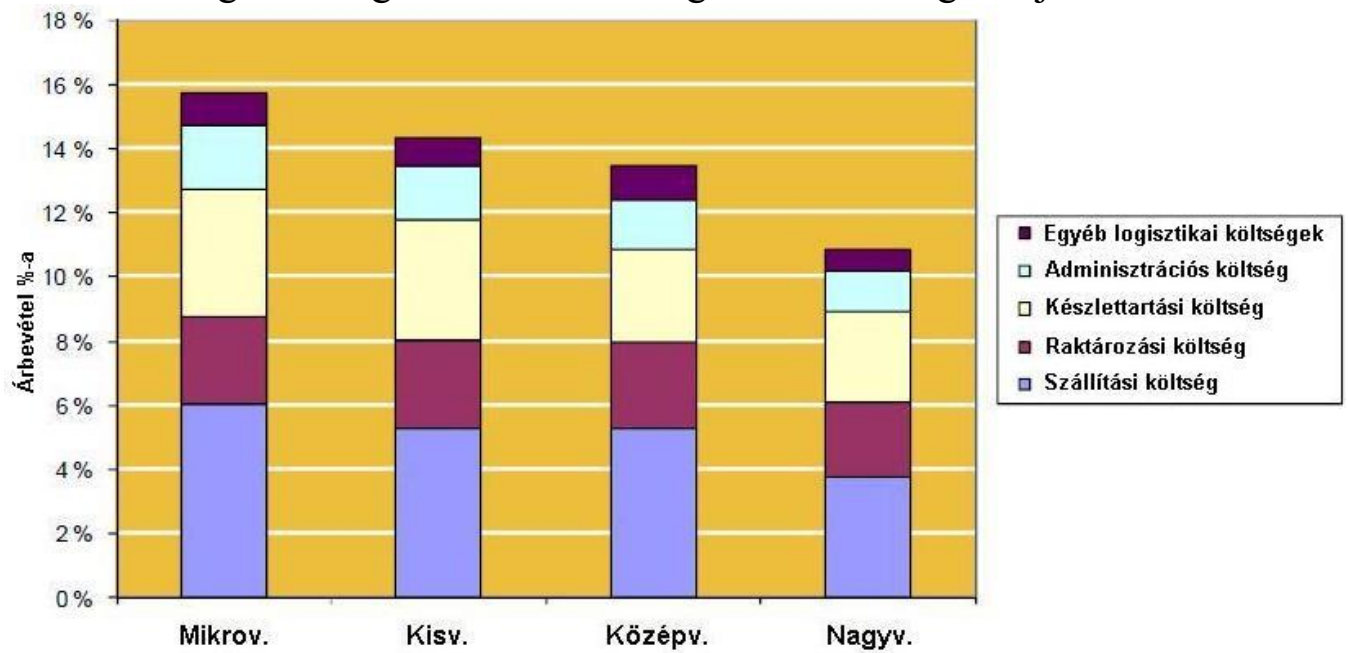

Forrás: Ojala et al. [2007] p. 38.

99 mexikói feldolgozóipari KKV logisztikai költségeit átlagosan az árbevétel 21,94\%-ra becsülték, mely a logisztikai gyakorlattal pozitívan korrelált. (Campos-Garcia et al. [2011])

A logisztikai költségek kapcsán gyakran célként fogalmazzák meg, hogy „a logisztikát a költségcsökkentés eszközeként kell használni (pl. szállítási költségeket tárgyalással vagy szervezéssel vagy raktárkapacitást készletinformációval csökkenteni)". (Harrington [1995] p. 60.) A megfelelő költségek egyes logisztikai definíciókban (pl. Ballou [1973]; Williams, [1987]; CLM [1986] idézi Halászné [1998]) és a logisztika céljait bemutató 7M-elvben (Szegedi és Prezenszki [2003]) is megjelennek, a Lewis et al. [1956] által bevezetett teljes költség koncepció és az átváltások (trade-off) pedig a logisztikai szemlélet máig meghatározó elemei. A vállalkozások logisztikai költségcsökkentését elsősorban a méretgazdaságosság kihasználásával lehet elérni. Wagner és Alderdice [2006] egy halászati szövetkezet példájával mutatta meg, hogy más KKV-kel együttmüködve és egyfajta disztribúciós központtá válva nagyméretü kiskereskedők beszállítójaként (pl. Tesco) a Scot Trout and Salmon az elosztási költségeit ötödével csökkentette. A finn kormányzati logisztikai politika egyik fö célja

42 A nagyvállalatok logisztikai költségei a mikrovállalkozásoknál kb. 5, a kis- és közepes vállalkozásoknál 3-4 százalékponttal alacsonyabbak. 
is éppen a vállalkozások logisztikai költségeinek csökkentése (Naula et al. [2006]) és a norvég közlekedéspolitika is közvetetten erre törekszik a „távolsági hátrány csökkentésével” (Hovi és Hansen [2010]). Ez a vállalati gyakorlatban is megjelenik (pl. Vízhányó [2006]), Halley és Guilhon [1997] szerint jellemzően az integrálatlan logisztikával rendelkezőknél. A költségcsökkentés hatása azonban limitált és ezzel elveszhetnek a fogyasztói érték növelésének lehetőségei (Kummer [1995]). Erre mutat rá La Londe is, amikor jelzi, hogy „egy 1 millió \$-s ügyfélnél a 300\$-os szállítási felár logisztikailag ugyan nem, de a vevőmegtartás szempontjából költséghatékony.” (La Londe, idézi Harrington [1995] p. 56.)

Összefoglalásként elmondható, hogy a kisvállalatok logisztikai teljesítményének megítélése pénzügyi, szervezeti és értékteremtési szemszögből eltérő (Halley és Guilhon [1996]) és kis- és középvállalkozások logisztikai válaszadási képességét erősíti a klaszterhez tartozás. (Grando és Belvedere [2006]) Egyes kutatások bizonyos logisztikai elemek és a vállalati teljesítmény között összefüggést találtak (Lea et al. [1996]; Orfanos et al. [2010]), de Töyli et al. [2008] és Solakivi et al. [2011] szerint nincs statisztikailag megfigyelhető pozitív kapcsolat a logisztikai és pénzügyi teljesítmény között.

A logisztikai teljesítmény elemeiből a költségszintek kiemelt szerepet kapnak, melyeket makro- vagy vállalati szinten vizsgálnak. Utóbbiaknál a felmérések szerint a KKV-k az összköltségük vagy az árbevételük 22\%-a alatti logisztikai összköltséggel rendelkeznek. A legtöbb KKV a logisztikai költségszintjével nem vagy csak mérsékelten van tisztában (Virum [1994]; Tempel és Meißner [2002]), vagy úgy vélik, hogy az nulla. (Berr et al. [1990]; Campos-Garcia et al. [2011]). A vállalat méretének növekedésével csökkenő logisztikai összköltség-szintre vonatkozó hüvelykujj-szabály Solakivi et al. [2010] szerint a középvállalkozásokra nem igaz. A logisztikai összköltség Lea et al. [1996] szerint az árbevétel emelkedésével közel azonos mértékben nő, mely kisebb mértékben az inputok hozzáadott értékének emelkedésével is bekövetkezik, a készletek forgási sebességének emelkedése viszont csökkenti a mértékét. A kutatók a hosszabb exportgyakorlattal rendelkező KKV-nál kisebb, a beszállítási problémákkal és a rövidtávú keresletcsökkenéssel szembesülőknél pedig magasabb logisztikai költségeket találtak (Lea et al. [1996]). Gyakran fogalmazzák meg célként a logisztikai költségek csökkentését (Harrington [1995]; Naula et al. [2006]; Hovi és Hansen [2010]; Vízhányó [2006]), azonban ezek hatása limitált (Kummer [1995]). 


\subsection{Logisztikai stratégia}

A logisztikai stratégia Heskett [1977] munkájában jelent meg először, mely Kent és Flint [1997] szerint csak egy évtizeddel később vált a „vállalati müködés vezérfonalának, a vállalati célokat és elérésük módját" (Chikán [2008] p. 187.) megfogalmazó vállalati stratégia részévé. Halley és Guilhon [1997] szerint a kisvállalatok logisztikai stratégiáját csak a vállalati stratégiájuk függvényében lehet vizsgálni. A kis- és középvállalkozások esetében a stratégiai tervezés gyenge, vagy egyáltalán nem létezik ${ }^{43}$. Ez azt a kockázatot hordozza magában, hogy a logisztikai rendszer tervezésénél kimaradnak a stratégiai elemek, a stratégiai előnyöket nem realizálják, sőt a logisztikai rendszer akár a vállalati stratégiát is közömbösítheti. Kummer [1995] szerint a kis- és középvállalkozások logisztikai elmaradása a gyors, konstans struktúrában történő növekedésükből, illetve menedzsment okokból (a vezetők szük köre, rögtönzés, megérzés, ösztön, inkább taktikai, mint stratégiai menedzsment, alacsony információs bázis, tanácsadási és képzési hajlandóság) is fakad. A logisztikának először nagyobb stratégiai szerepet kell adni, hogy a szükséges rossz helyett potenciális erőforrásként tekintsenek rá. (Harrington [1995])

Kummer [1995] a stratégiai tervezésben a logisztikai tényezők fontosságát is vizsgálta, mely közül a vállalkozások versenyképességére gyakorolt hatást találta a legerösebbnek. Bár utóbbinál nem ${ }^{44}$, de a telephely-választási és a beruházás-racionalizálási szempontoknál szignifikáns eltérést talált a különböző vállalati méretkategóriák között.

\footnotetext{
${ }^{43}$ A magyar kis- és középvállalkozások esetében például a stratégia inkább kialakul, mintsem kialakítják. (Salamonné [2007] p. 23.)

${ }^{44}$ Csak 6\%-os szignifikancia szinten.
} 
9. ábra: Logisztikai tényezők fontossága a német KKV-k stratégiai tervezésében ${ }^{45}$

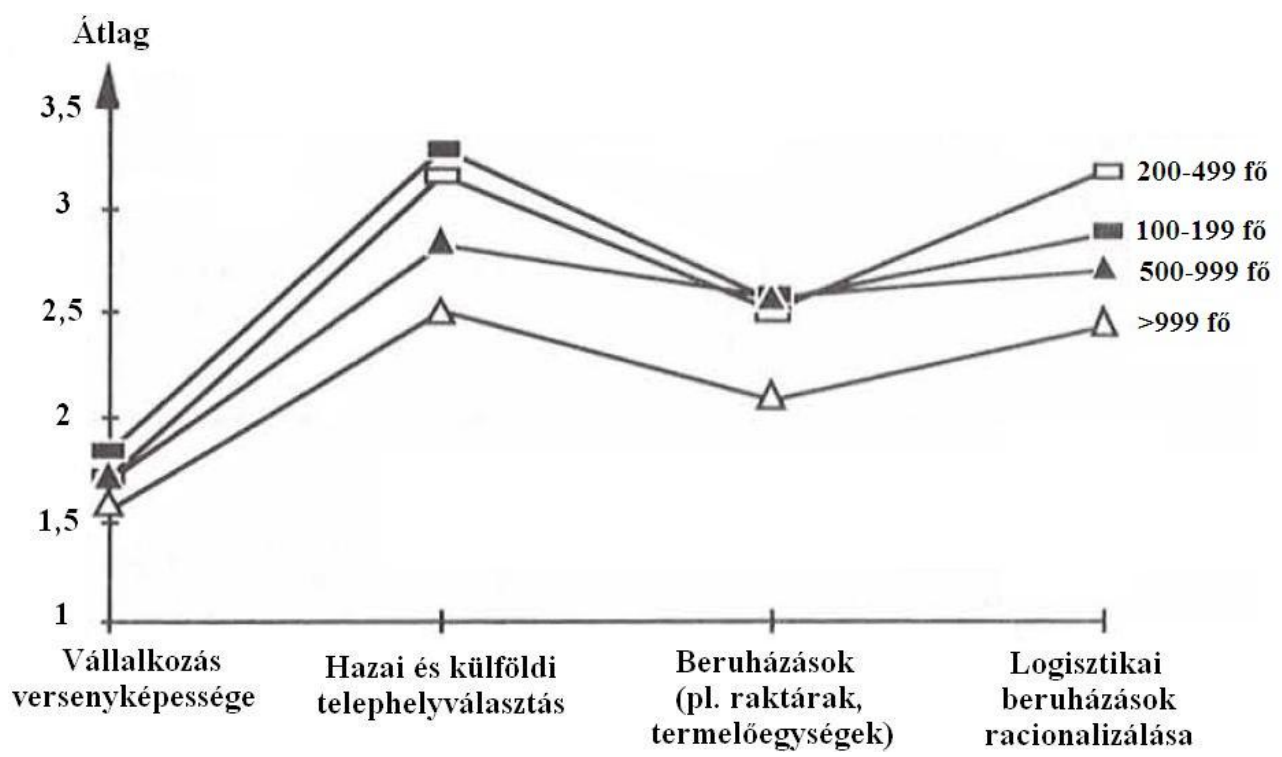

Forrás: Kummer [1995] p. 42.

A logisztikai koncepciók bevezetésének okai között is az első helyen szerepelt a verseny. Kummer [1992] szerint e tekintetben nem volt szignifikáns különbség a vállalati méretkategóriák között, azonban a nagyvállalatok beszállítói, megnövekedett nemzetközi fókusza és vásárlói tekintetében már igen. A logisztikai koncepciók bevezetésének korlátjaként a menedzsment túl alacsony kapacitását és az alkalmazottak hiányát, az elérhetetlen vagy használhatatlan logisztikai információkat, a nem létező logisztikai tervezést és az ad-hoc módon végrehajtott tevékenységeket nevezték meg. (Kummer [1992] p. 173.)

\footnotetext{
${ }^{45}$ Ötfokozatú (1 nagyon fontos ... 5 nincs jelentősége) Likert-skálán
} 
10. ábra: Logisztikai koncepciók bevezetésének okai a német KKV-k körében ${ }^{46}$

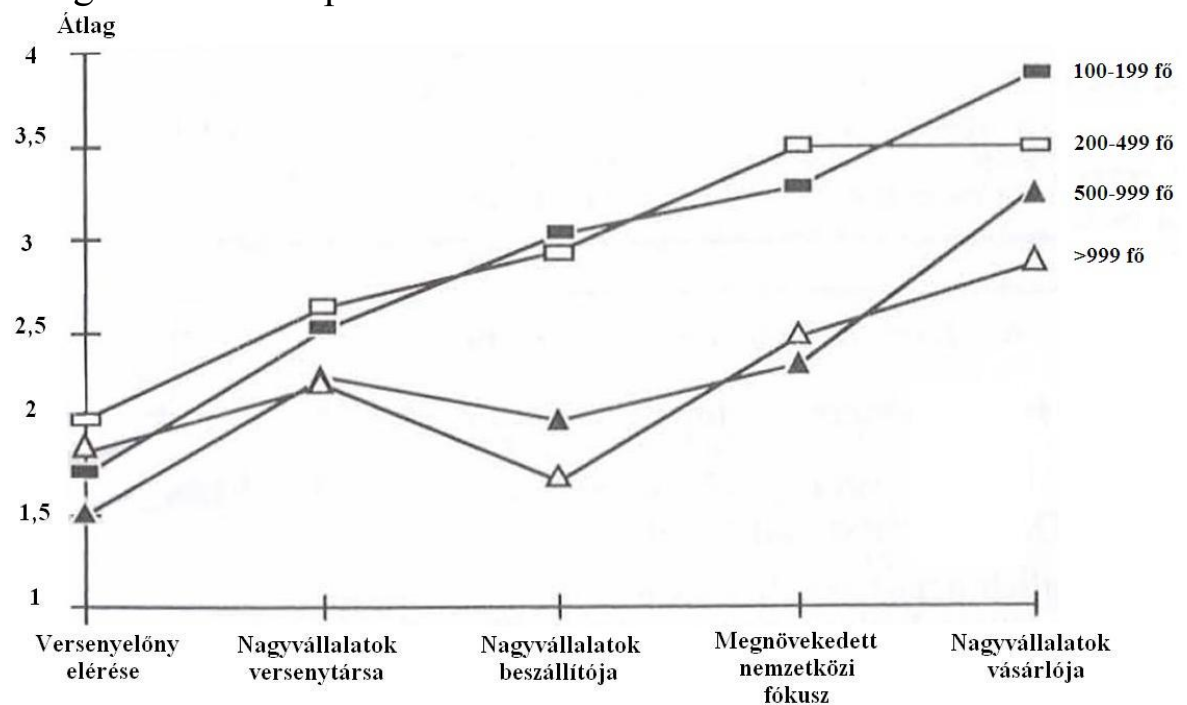

Forrás: Kummer [1995] p. 43.

Kummer [1995] a kis- és középvállalkozások logisztikai szintjének fejlödésének négy fázisát különítette el, melyek a német vállalkozások közötti eloszlását a 11. ábra mutatja:

1. Az elő-logisztika fokozatnál a vállalati logisztikai feladatok még koordinálatlanok.

2. A logisztika iránti érdeklődés jelenti az alkalmazottak logisztikai ismeretének kezdetét (pl. szemináriumok látogatása), és az első pilot tanulmányokat.

3. A kezdő szintű logisztika lépcső a logisztikai koncepció elszigetelt, szigetszerü megvalósítását tartalmazza.

4. A profi szintű logisztika fázisnál az integrált logisztikai koncepciók már túllépnek a vállalat határain, kiaknázzák a tanulási/tapasztalati görbe hatását a logisztikában, és a logisztikai koncepció mélyen beépül a vállalati gyakorlatba.

\footnotetext{
${ }^{46}$ Ötfokozatú (1 nagyon fontos ... 5 nincs jelentősége) Likert skálán
} 
11. ábra: Német KKV-k logisztikai fejlődési szintjeinek megoszlása

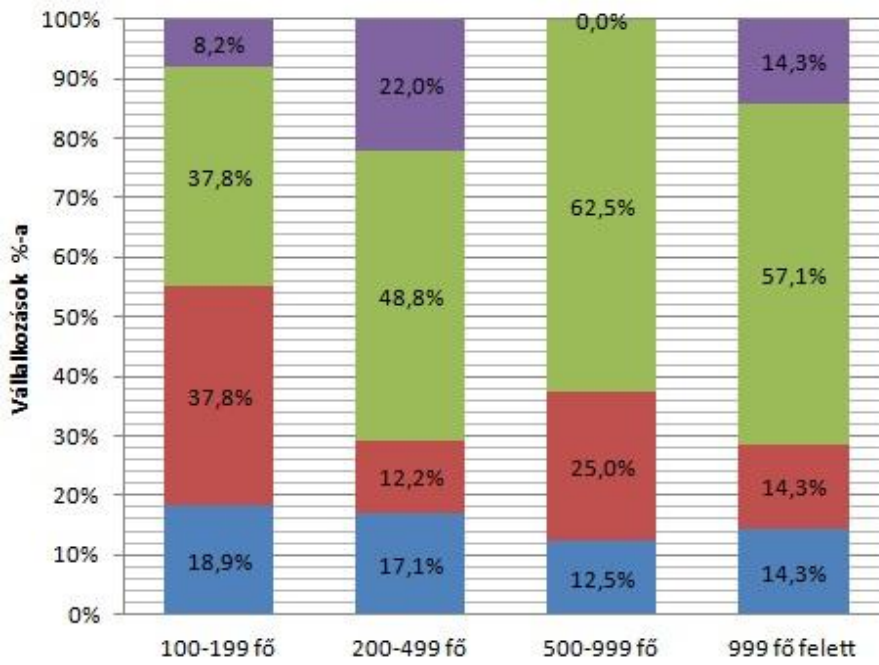

- Profi szintũ logisztika

- Kezdốszintû́ logisztika

n Logisztika iránt érdeklődố

nElố-logisztika

Forrás: Kummer [1995] p. 53.

Halley és Guilhon [1997] szerint nincs jó és rossz kisvállalati logisztikai stratégia, melyet két kulcstényező határoz meg: a tulajdonos-menedzser, és a vállalat környezetétől való függőségi viszonya. A szerzők alapvetően háromféle kisvállalati logisztikai stratégiai modellt találtak (Halley és Guilhon [1997] p. 487-488.):

- „Az értéklánc magas hozzáadott értékű tevékenységekre fókuszálását teszi lehetővé a megfontolt, proaktív stratégia.” Itt a logisztika stratégiai funkció, mely megszabja a szervezeti formát, a kompetenciákat, a tevékenységi köröket, miközben a tulajdonos-menedzser megőrzi kontrollját a műveletek felett.

- „A logisztikai tevékenységek fokozatos beillesztésével a belső és külső források maximalizálását segíti a reaktív stratégia.” „A logisztika ebben a változatban csak egy adaptációs eszköz, mely csak egy funkció a szervezetben.”

- „A fiatal kisvállalatok, melyek termékeiknek és folyamataiknak minőségi imázst keresnek, miközben partnereiktöl való függetlenségüket megörzik ún. átmeneti, kifejlődő stratégiával rendelkeznek."

A logisztikai stratégiát csak a megfelelő feltételek fennállásakor lehet megvalósítani, és egyik kisvállalatot sem kellene arra kényszeríteni, hogy stratégiai ügyei közé felvegye a logisztikát, de ha így tesz, akkor a piacon és belső folyamataiban hatékonyabb lesz. (Halley és Guilhon, [1997] p. 490.) 
A kis- és középvállalkozások beszerzési szakirodalmán belül a stratégiai beszerzést ${ }^{47}$ is kutatják. Pressey et al. [2009] 97 feldolgozóipari KKV-t felmérve azt találta, hogy ilyet csak 12,6\%-uk, beszállító-értékelést pedig 48,9\%-a végzett. Eredményeik egybeestek Quayle [2000] azon megállapításával, hogy a méretbeli eltérések és a piac kompetitív természete miatt a stratégiai beszerzés nem alkalmas a kis- és középvállalkozásoknak, melyek cash-flow okokból gyakrabban és kis mennyiségekben kénytelenek beszerezni. (Zheng et al. [2004]; Zheng et al. [2007]) Pressey et al. [2009] a beszállítóktól elvárt nyolc képesség-csoport alapján 3 klaszterbe sorolták a KKV-ket, melyből a holisztikus beszerzők a legigényesebbek, mivel minden képességben többet várnak el a beszállítóiktól, mint a folyamat, és a hangsúlyt a kiszállítási és termelési képességekre helyező logisztikus beszerzők.

12. ábra: KKV-k által elvárt beszállítói képességek

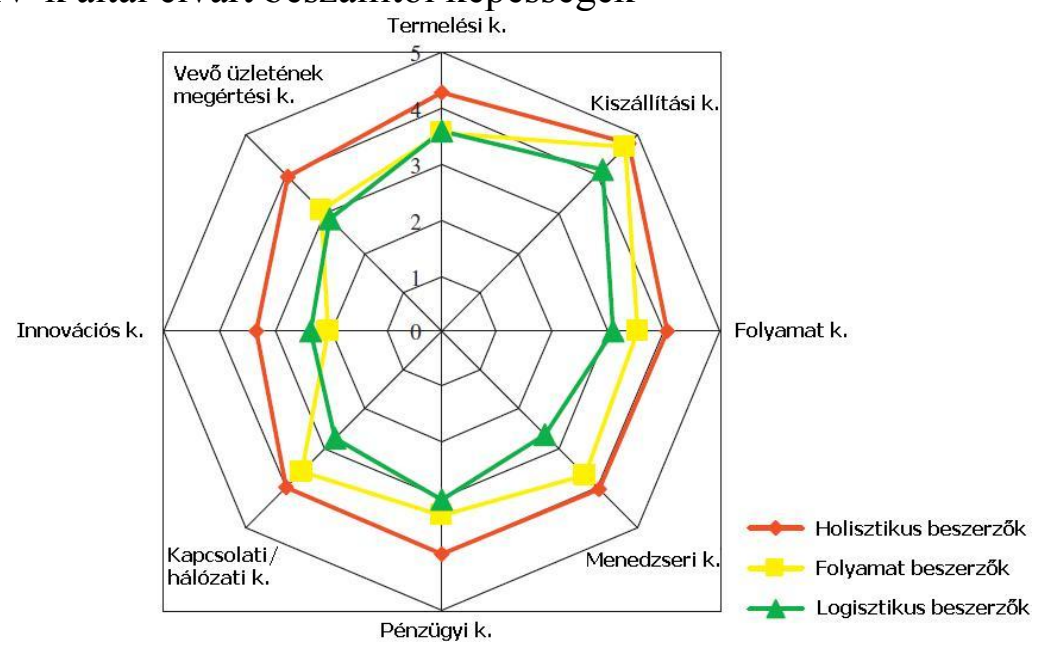

Forrás: Pressey et al. [2009] p. 220.

Összefoglalásként elmondható, hogy a logisztika stratégiát csak a vállalati stratégia függvényében lehet vizsgálni, mely Halley és Guilhon [1997] szerint a KKV esetében gyenge vagy nem létezik. A tervezés során a KKV-k a logisztika versenyképességre gyakorolt hatását tekintik a legerősebbnek és a koncepciók bevezetésénél is a versenyelőny elérését célozzák meg. A KKV-k az elő-logisztika, e tevékenység iránti érdeklődés, és a kezdő szint után jutnak elő a professzionális szintű logisztikáig. (Kummer [1995]). A tulajdonos-menedzser és a vállalat környezetétől való függőségi viszonya alapján proaktív, reaktív és kifejlődő logisztikai stratégiát különböztethető

${ }^{47}$ Hosszútávú beszerzési terv készítése, a vállalkozás stratégiai tervéhez igazítása, a kulcsbeszállítókkal folytatott viszony típusának meghatározása, és más funkciókkal történő együttműködés. (Pressey et al. [2009]) 
meg (Halley és Guilhon [1997]). A szerzők szerint a kisvállalatot nem lehet arra kényszeríteni, hogy a logisztikát a stratégiai ügyei közé felvegye és a logisztikai stratégiát nem lehet jó vagy rossz kategóriákba sorolni.

\subsection{A logisztika szervezeti megjelenése, koordinációja, alkalmazottak képzése}

A szakirodalomban a logisztikai, mint vállalati tevékenység megszervezése és a szervezetbe illesztése fontos szerepet kap. A KKV-k logisztikai szervezetét vizsgáló kutatások általában leíróak és gyakran nem tudatosan, de a kontingencia-elméletet empirikus igazolását végzik. Egyúttal a kutatók a kontingencia-elmélet egyik jelenkori irányzatának (Donaldson [2001]) részesévé válnak azzal, hogy alkalmazzák azt a saját tudományterületükre.

A több irányzatban gyökerező (pl. weberi bürokráciaelmélet) kontingencia-elmélet különösen annak strukturális irányzata - a szervezet működési feltételei (kontingenciatényezők) és struktúrája közötti összefüggéseket vizsgálja. (Kieser [1995]) A kontingencia-tényezők között a kutatásokban (pl. Aston tanulmányok) már az 1960-as évektől kiemelt figyelmet kapott a szervezet mérete, melyet általában a szervezet tagjainak létszámával mérnek (Kieser [1995]). Donaldson [1996] vizsgálatában arra jutott, hogy más módszerekkel (pl. árbevétel, eszközérték) a szervezet méretének hatásai, ha nem is tökéletesen azonosan, de erősen pozitív kapcsolatban állnak. Sajnos a KKV-k logisztikai szervezettel foglalkozó kutatásai sem jutnak többre a kontingenciaelmélet ezzel kapcsolatos csekély információtartalmú következtetésein. (pl. „nagy szervezetek kisebbekkel való összehasonlítása ... szignifikánsan nagyobb mértékü specializációt és professzionalizálódást, erősebb programozást és tervezést, nagyobb méretü formalizáltságot és hangsúlyosabb decentralizációt mutat.” (Kieser [1995] p. 223.)

A kisebb méretü vállalkozásoknál a funkcionális specializáció még nem elég mély, ezért az esetek többségében a logisztika formalizáltan nem jelenik meg, és a korlátozott erőforrások miatt ezzel általában más területért is felelős, a logisztikában járatlan személyt bíznak meg. (Harrington [1995]). Kummer [1995] szerint a kis- és középvállalkozások tárolási, szállítási személyzete túlzott méretü. 
Bowersox et al. [2002] értelmezésében a logisztikai szervezetfejlődés elején ez a tevékenység még elaprózott (0. fázis), melyet a funkcionális egyesülés (1-3. fázis), a folyamatorientáció (4. fázis), végül a virtuális szervezet (5. fázis) kialakítása követ. Ehhez hasonló Frazelle [2002] megközelítése is, mely a funkcionális, integrált, folyamatorientált majd elosztott szervezet fázisokat különböztet meg. A KKV-k logisztikai kutatásai az elaprózott és funkcionális fázisbeliséget igazolják vissza. Gelinas és Bigras [2004] ${ }^{48}$ szerint a logisztika gyakran egyszerre több szervezeti egység között kerül szétosztásra, melyet a 9. táblázatban bemutatott quebeci kutatás (Roy et al. [2002]) eredményei is alátámasztanak.

9. táblázat: Formalizált logisztikai szervezet quebeci vállalkozásoknál

\begin{tabular}{|l|c|c|c|}
\hline & Kisvállalkozás & Középvállalkozás & Nagyvállalat \\
\hline Nincs formalizált logisztika & $53,1 \%$ & $33,8 \%$ & $15,0 \%$ \\
\hline $\begin{array}{l}\text { A logisztikai tevékenységek } \\
\text { több osztályon vannak } \\
\text { szétosztva }\end{array}$ & $27,8 \%$ & $47,8 \%$ & $41,9 \%$ \\
\hline Logisztikai osztály & $19,1 \%$ & $18,4 \%$ & $43,1 \%$ \\
\hline
\end{tabular}

Forrás: Roy et al. [2002] p. 8.

Kummer [1995] kutatása is a logisztika több helyen történő megjelenését erősíti; e funkció vállalaton belüli helyeként a kis, közepes és nagy KKV-k leggyakrabban a beszerzés és anyagmenedzsmentet jelölték meg, melynek eloszlását a 13. ábra mutatja.

13. ábra: A logisztikai funkció vállalaton belül elképzelt helye Németországban

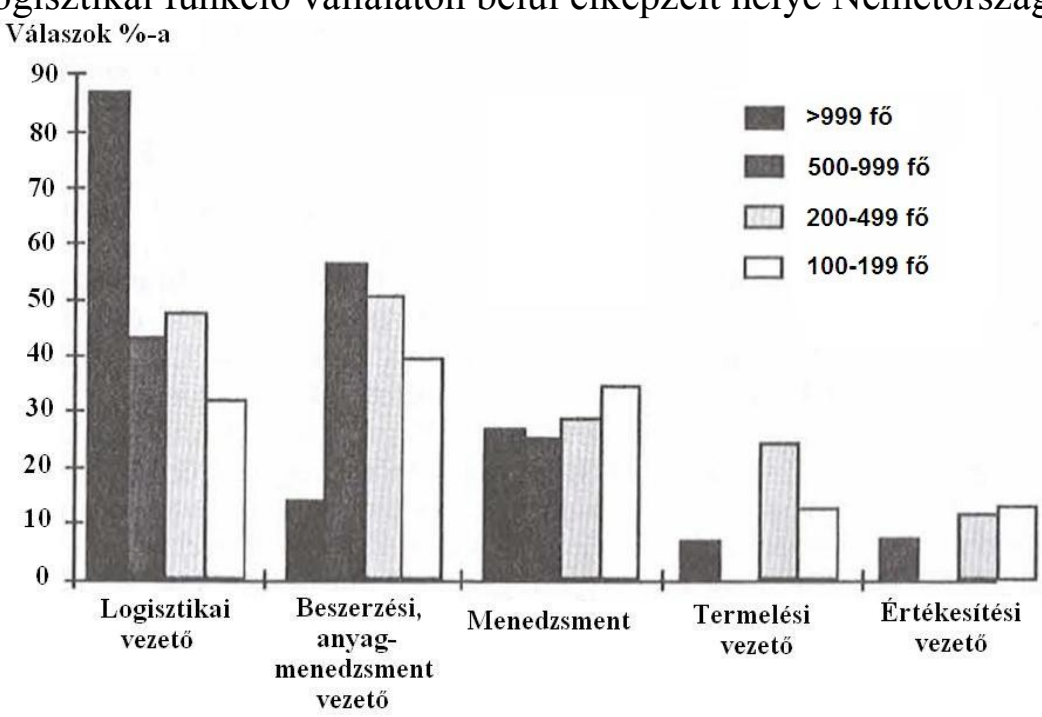

Forrás: Kummer [1995] p. 48.

\footnotetext{
${ }^{48}$ A formális logisztikai funkció nélküli cégek 78\%-a kisvállalat, és csupán $0,5 \%$-a volt nagyvállalat. A logisztikai osztállyal rendelkező cégek $18 \%$-a kis-, és $41 \%$-a nagyvállalat.
} 
Kummer [1992] az alábbi logisztikai osztály megjelenési arányokat találta, mely többek között rámutat a létszám- és árbevétel-alapú KKV meghatározás eltéréseire is.

10. táblázat: Működő logisztikai osztályok aránya német KKV-knál vállalatméret alapján

\begin{tabular}{|l|c|c|c|c|c|}
\hline $\begin{array}{l}\text { KKV } \\
\text { meghatározás }\end{array}$ & $\begin{array}{c}\text { Kis } \\
\text { KKV }\end{array}$ & $\begin{array}{c}\text { Közepes } \\
\text { KKV }\end{array}$ & $\begin{array}{c}\text { Nagy } \\
\text { KKV }\end{array}$ & Nagyvállalat & Összesen \\
\hline Létszámalapú & $43,8 \%$ & $54,1 \%$ & $33,3 \%$ & $64,3 \%$ & $49,0 \%$ \\
\hline $\begin{array}{l}\text { Árbevétel } \\
\text { alapú }\end{array}$ & $40,0 \%$ & $42,0 \%$ & $48,0 \%$ & $58,3 \%$ & $49,0 \%$ \\
\hline
\end{tabular}

Forrás: Kummer [1992] p. 160.

A kutatások változatos arányokat találnak a logisztikai funkció szervezeti megjelenésére:

- A pittsburghi feldolgozóipari kisvállalatok közel fele külön osztályba szervezte a beszerzést, 30\%-uk pedig ezért felelős személyt bízott meg. (Presutti [1988])

- A nemzetközi kereskedelembe bekapcsolódott, logisztikai iránt érdeklődő amerikai kisvállalatok 77,08\%-a rendelkezett logisztikai vagy szállítási osztállyal. (Murphy et al. [1995])

- A dán kisvállalatok $62,5 \%$-a centralizált beszerzési egységgel rendelkezett, az amerikai kisvállalatok 48,3\%-nál ez egy személy fö felelőssége volt. (Paik et al. [2009])

A logisztika vállalati hierarchián belüli szintjét és e funkció_koordinációját vizsgáló kutatások azt találták, hogy:

- A hierarchia közép vagy felső szintjén található logisztikai döntések száma igen alacsony $(8,6 \%)$ volt. (Berr et al. [1990])

- „A menedzsment a logisztikai problémákat más üzleti feladatokkal együtt operatívan oldja meg, logisztikai menedzsment nem létezik.” (Kummer [1995] p. 35.) és a logisztikai döntéshozatali szabályok tisztázatlanok. (Kummer [1995] p. 58.)

- A kisvállalatok menedzserei a beszerzést inkább taktikai, mint stratégiai területnek tekintették. (Paik et al. [2009])

- A quebeci kis- és középvállalatok esetében általában alacsony szinten kezelték a logisztikát. (Roy et al. [2002]) 
11. táblázat: A logisztika legmagasabb szintje a quebeci vállalkozások vezetésében

\begin{tabular}{|l|c|c|c|}
\hline & Kisvállalat & Középvállalat & Nagyvállalat \\
\hline Alelnök & $16,2 \%$ & $18,1 \%$ & $31,3 \%$ \\
\hline Igazgató & $36,0 \%$ & $50,5 \%$ & $50,3 \%$ \\
\hline Menedzser & $15,7 \%$ & $10,0 \%$ & $5,5 \%$ \\
\hline Egyéb & $11,7 \%$ & $7,4 \%$ & $5,5 \%$ \\
\hline Nincs & $20,3 \%$ & $14,0 \%$ & $7,4 \%$ \\
\hline
\end{tabular}

Forrás: Roy et al. [2002] p. 8.

- Heinrich és Felhofer [1985] szerint a logisztikai részfeladatok koordinációja szinte csak informális koordináción keresztül történt és az egyes részterületek (értékesítés, termelés, beszerzés) összehangolása gyenge volt.

- Haan et al. [2007] a lengyel KKV-k körében végzett felmérésükkel megmutatták, hogy növekedésük függvényében különböző koordinációs mechanizmusokat használnak, és többségüknek a logisztika és ellátási lánc menedzsmentje még nem eléggé fejlett. A nagyobb méretü KKV-k formálisabb menedzsmenttechnikákat (pl. készletmenedzsment és modellezés) használtak, hogy a megnövekedett komplexitást kezeljék.

A vállalkozások logisztikája tekintetében két növekedési küszöböt azonosítottak (Kummer [1995] p. 60.):

- 200 alkalmazott felett koordinációs problémák merülnek fel a logisztikával kapcsolatban. E szint alatt a logisztika kivitelezési részére fókuszálnak, és a koordinációt nem tekintik annyira fontosnak. Ezt improvizációval oldják meg. Itt a logisztikai koncepcióknak nincs szervezeti megvalósítása.

- 1000 alkalmazottnál az ún. know-how küszöb lép fel. A logisztikai koncepciók ebben a körben elterjedtebbek, a növekvő komplexitással a logisztika formalizáltabb lesz, bár egy helyre történő integrálása kevésbé jellemző.

A kutatások vizsgálják a logisztikai alkalmazottak képzettségét és oktatását:

- A kisvállalatok fuvarozási szolgáltatás „,beszerzői”49 időnyomás alatt vannak, e területen csekély vagy semmilyen szakmai képzettséggel (pl. a tömegek, útvonalak,

49 A vállalkozás azon munkatársa, mely a logisztikai szolgáltatásokat megrendeli: 57\%-ban a menedzserek, 43\%-ban titkárok, ügyintézők, raktárosok. 
háztól-házig vagy termináltól-terminálig függvényében eltérő díjak) sem rendelkeztek. (Evans et al., 1990)

- A KKV-knál a logisztikai (Tempel és Meißner [2002]) és beszerzési szakértelem (Ellegaard [2009]) gyakran nem áll rendelkezésre, egyetemi végzettségü specialistákat relatíve ritkán találni náluk.

- A vállalat vezetésének jelentő kisvállalati beszerzésnél leginkább a munka közbeni gyakorlattal történik a képzés, ami azért elgondolkodtató, mivel tanácsadók szerint a beszerzés szervezési és a müködtetési képességei az ilyen költségeket akár 10-15\%kal is megváltoztathatja. (Presutti [1988])

- A vállalkozások 43\%-a a logisztika területén nem nyújt képzést munkatársainak. (Berr et al. [1990])

- A kisvállalatok alkalmazottaiknak az üzletmenet fenntartása miatt nincs idejük képzésekre járni, ezért logisztikai tanácsokat fuvarozójuktól vagy raktárszolgáltatójuktól kérnek. (Harrington [1995])

- A jelentős logisztikai tevékenységgel rendelkező cégek 80\%-a külső szakértőt hívott, elsősorban menedzsment tanácsadót. A kutatás szerint ezek a vállalkozások nagy hangsúlyt fektettek alkalmazottaik oktatására, 40\%-uk például minden egyes tagját képezte. (Halley és Guilhon [1997])

- A 12. táblázatban szereplő értékek Gelinas és Bigras [2004] felmérését megelőző évek oktatási arányait mutatják:

12. táblázat: Az elmúlt öt évben legalább egy alkalmazottját továbbképző quebeci vállalatok megoszlása

\begin{tabular}{|l|c|c|}
\hline & Kisvállalat & Nagyvállalat \\
\hline Ellátás & $6 \%$ & $49 \%$ \\
\hline Elörejelzés & $1 \%$ & $19 \%$ \\
\hline Disztribúció & $3 \%$ & $28 \%$ \\
\hline Információ-menedzsment & $17 \%$ & $58 \%$ \\
\hline Logisztika & $6 \%$ & $44 \%$ \\
\hline Termeléstervezés & $11 \%$ & $42 \%$ \\
\hline Tevékenység-menedzsment & $24 \%$ & $35 \%$ \\
\hline Készletmenedzsment & $9 \%$ & $49 \%$ \\
\hline Szállítás & $10 \%$ & $42 \%$ \\
\hline
\end{tabular}

Forrás: Gelinas és Bigras [2004] p. 272.

A logisztika szervezeti megjelenésével, koordinációjával kapcsolatos kutatásokról összegzésként elmondható, hogy sajnos nem lépnek túl a kontingencia-elmélet szervezet 
méretével kapcsolatos csekély információtartalmú következtetésein, bár azokat legalább empirikusan alátámasztják. A logisztika formalizáltan a KKV-knál többnyire nem jelenik meg, ha igen, akkor szétszórtan (Kummer [1995]; Roy et al. [2002]; Gelinas és Bigras [2004]). A logisztikai feladatokat alacsony szinten kezelik (Presutti [1988]; Berr et al. [1990]; Kummer [1995]; Roy et al. [2002]; Paik et al. [2009]), a döntéshozatali szabályok tisztázatlanok (Kummer [1995]), a részfeladatokat informálisan koordinálják. (Heinrich és Felhofer [1985]) A KKV-k általában többfunkciós, logisztikával is foglalkozó alkalmazottainak képzettsége gyenge (Evans et al. [1990]; Tempel és Meißner [2002]; Ellegaard [2009]), oktatásuk alacsony szintű (Berr et al. [1990]; Harrington [1995]; Gelinas és Bigras [2004]), bár van ennek ellentmondó felmérés is. (Halley és Guilhon [1997])

\subsection{Logisztikai eszközök, módszerek}

Klaus [2009] a logisztikában alkalmazott eszközök gyökereit Babbage „A gépek és a gyártás gazdaságtanára”, illetve Taylor „Tudományos menedzsmentjére” vezette vissza. A területet a logisztikai kutatások „,eszközökkel való ellátásának” irányzatába sorolta, melyet a 70-es években német mérnökök (pl. Jünemann, Baumgarten) indítottak el áruáramlási, raktár-technológiái vizsgálataikkal (Klaus [2009]). Napjaink e téren az elogisztika, az e-kereskedelem, az Internetes és a rádiófrekvenciás azonosítási (RFID) kutatások a meghatározóak.

A logisztikai folyamatok megvalósítására a vállalkozások számos eszközt használnak, melyek ismerete, és különösen alkalmazása a logisztikai know-how jó indikátora. Ezek közül a logisztikai tevékenység magas adat- és számításigénye miatt az informatika kap nagyobb figyelmet, de a logisztikai együttmüködésekkel, szövetségekkel, a beszerzési technikákkal és egyéb megoldásokat is foglalkoznak a felmérések.

\subsubsection{Informatika}

Az informatikai megoldások a KKV-k körében egyre jobban terjednek, de beruházás- és tudásigényük miatt elsősorban az olcsóbb és egyszerübb eszközöket használják. Ezt mutatja az, hogy:

- 1989-ben egy vizsgálat 400 francia mezőgazdasági és élelmiszeripari kisvállalat 22,2\%-nál talált integrált technikát ${ }^{50}$, míg öt évvel később már 42,6\%-uknál. (Halley és Guilhon [1997])

\footnotetext{
${ }^{50}$ Például számítógép támogatta termelésmenedzsment, JIT, EDI, készletmenedzsment
} 
- Pearson és Semeijn [1999] szerint az elektronikus adatcsere (EDI) a kisvállalatok körében kevésbé volt jelentős, mint a nagyoknál, melynek hátterében annak jelentős beruházásigénye, és a kevesebb tapasztalat állt. Gelinas és Bigras [2004] azt találta, hogy EDI-t csak a kisvállalatok 1,5\%-a használt, míg a nagyok 20\%-a.

- Roy et al. [2002] 688 quebeci vállalkozást vizsgálva azt találták, hogy a rendelésfogadás döntően telefonon és faxon történt, melyet az EDI és az Internet követett. A logisztikai tevékenységek számítógépesítettsége különösen alacsony volt a kisvállalkozásoknál (pl. anyagszükséglet-tervezésnél 30,6\%-uk használta). A kutatásban feltárt egyéb eszközhasználatot a 13. táblázat tartalmazza.

13. táblázat: Logisztika a quebeci vállalkozások gyakorlatban

\begin{tabular}{|l|c|c|c|}
\hline & Kisvállalat & Középvállalat & Nagyvállalat \\
\hline Vonalkód használata & $25,1 \%$ & $48,8 \%$ & $70,0 \%$ \\
\hline $\begin{array}{l}\text { Információk megosztása, } \\
\text { automatizált vásárlás }\end{array}$ & $25,9 \%$ & $44,9 \%$ & $47,5 \%$ \\
\hline Készletmenedzsment & $29,6 \%$ & $31,1 \%$ & $40,0 \%$ \\
\hline Logisztikai együttmüködés & $28,0 \%$ & $48,5 \%$ & $60,4 \%$ \\
\hline $\begin{array}{l}\text { Logisztikai indikátorok } \\
\text { használata }\end{array}$ & $25,6 \%$ & $31,3 \%$ & $61,6 \%$ \\
\hline Folyamatos készletfeltöltés & $12,3 \%$ & $19,9 \%$ & $35,2 \%$ \\
\hline
\end{tabular}

Forrás: Roy et al. [2002] p. 5.

- A magyar KKV-k körében végzett felmérés kis mintájában 67\%-os volt az integrált rendszerrel, vagy speciális programmal nyomonkövetett készletek aránya, a vállalkozások 33\%-a pedig ehhez csupán Excelt használt. (Vízhányó [2006])

- A finn nagyvállalatok a rendelés- és szállításmenedzsmentben az információs rendszereket gyakrabban és sokoldalúbban használták, mint a KKV-k. Az intranetet/extranetet például a nagyvállalatok 60-80\%-a, míg a mikro- és kisvállalkozások csak 20-40\%-a használta. Az e-mail teljesen megszokott volt még a mikrovállalkozások kb. 80\%-a is rendszeresen használta. (Solakivi et al. [2009] p. 77.) 
14. ábra: Információs rendszerek használata finn vállalatok rendelés- és szállításmenedzsmentjében

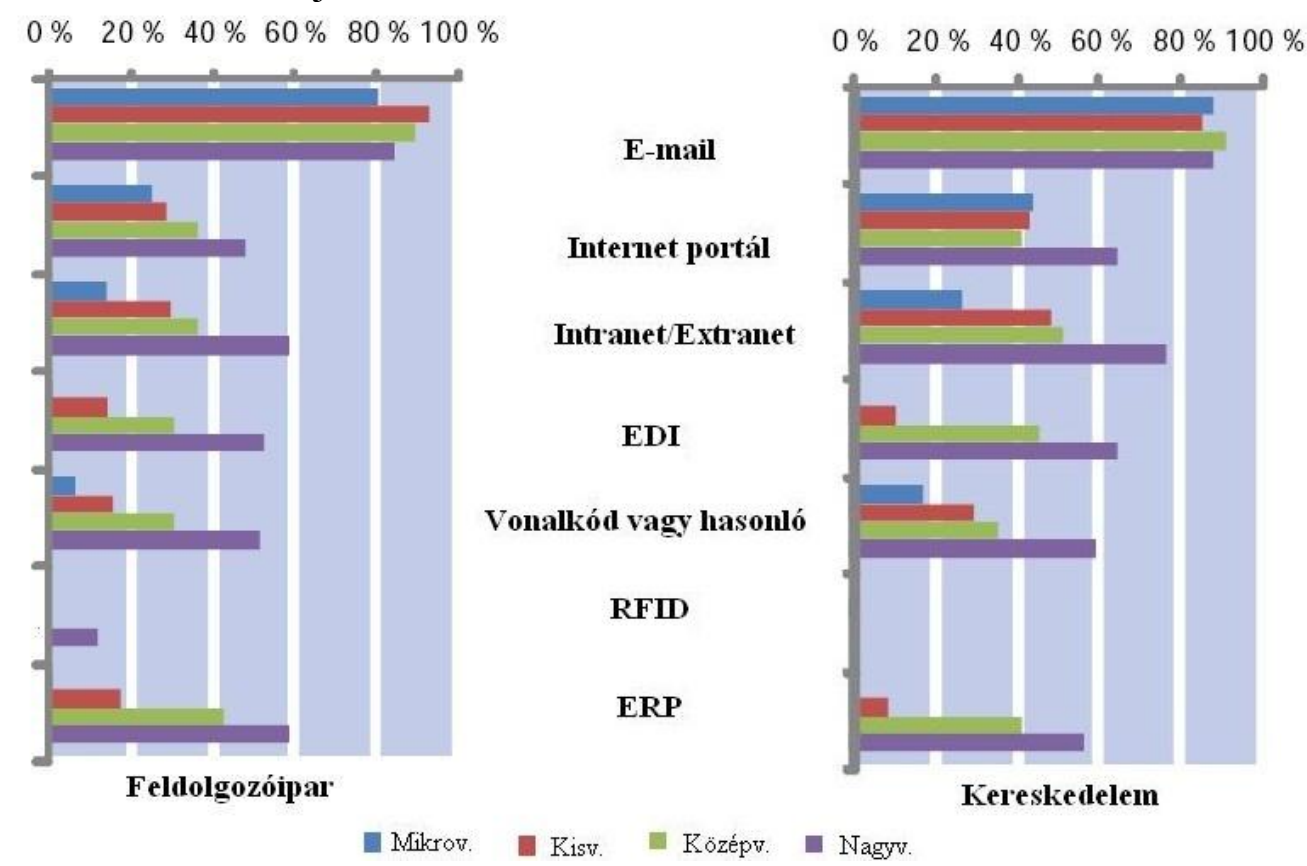

Forrás: Solakivi et al. [2009] p. 77.

Fodor [2005] 134 magyarországi kis- és középvállalkozást vizsgáló kutatásának legfőbb tapasztalata az volt, hogy a logisztikai információs rendszer - beleértve a vállalati logisztikai tevékenységet és az ellátási lánc menedzsmentet támogató minden informatikai alkalmazást - bevezetésével a kis- és középvállalkozások nem a logisztikai költségek csökkentésével, hanem a vevőkiszolgálási szint növelésével jutottak versenyelőnyhöz. A magyar KKV-k a logisztikai területen először a vállalati anyagáramlási folyamatokat képezték le információs rendszerekkel, de előfordult, hogy idővel a logisztikai optimalizációs folyamatot támogató logisztikai vezetői információs rendszert is létrehozták.

Szabó [2005] 79 magyarországi KKV ügyvezetőjével, logisztikai vezetőjével készített mélyinterjú során azt találta, hogy a vállalati információs rendszerek átlagosan csak $35 \%$-ban ${ }^{51}$ támogatták a logisztikát, ami a szerző szerint nem megfelelő.

Gelei és Nagy [2010] által vizsgált magyarországi KKV-k az azonosításhoz elsősorban vállalat-specifikus és vonalkódokat használtak, az RFID pedig egyáltalán nem jelent meg. A KKV-k tervezett fejlesztéseinek aránya megegyezett a nagyvállalatokéval. A

${ }^{51}$ A termelőknél 43\%, a kereskedőknél 41\%, a szolgáltatóknál 18\% 
KKV-k a kutatók szerint döntően a piacon elérhető, standard integrált vállaltirányítási rendszereket alkalmaztak, de szigetszerü, egyedi megoldások is előfordultak; elmaradásuk a készletmenedzsment, a termelésirányítás és a beszerzés területén volt

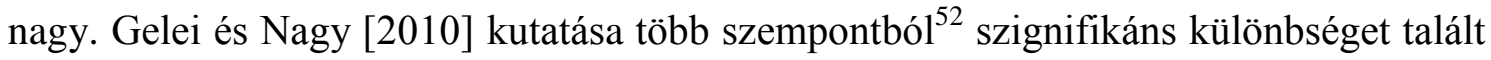
a nagyvállalatok és KKV-k között. A megrendelővel, beszállítóval és logisztikai szolgáltató partnerrel történő kommunikációban a KKV-k a kevésbé fejlett és kevésbé biztonságos kommunikációs technológiákat használtak.

\subsubsection{Együttmüködés}

A KKV-k logisztikai eszközei között az együttmüködést mind elméleti mind pedig gyakorlati szinten vizsgálják.

Finley [1984] jelezte, hogy a beszerzési volumen alacsony volta a kisvállalatokat sok esetben aszimmetrikus erőpozícióba helyezi a nagyobb vevőkkel szemben, mely csökkenti az alacsonyabb árak elérési esélyét. Ennek kezelésére beszerzési csoportok és szövetkezetek létrehozását javasolta. Hudson és McArthur [1994] elméleti cikkében azt találta, hogy magas kockázatuk és tranzakciós költségeik miatt a kisvállalatok nem vonzók egy tranzakcióban. A kisvállalatok tranzakciós költségeit fiatal voltuk miatt a jó hírnevük hiánya és a beszerzésbeli tapasztalatlanságuk növeli, ezért Hudson és McArthur [1994] szerint szakértői hálózatba kellene bekapcsolódniuk. Chikán et al. [2007] hasonló javaslatot tett, illetve az egynemü logisztikai tevékenységek (pl. beszerzési, raktározási, szállítmányozási, disztribúciós „pool”-ok) vagy vertikális, többféle szolgáltatás végzésére alkalmas „logisztikai szövetkezetek” létrehozását ajánlja.

A KKV-k logisztikai együttműködésének gyakorlati szintü vizsgálata során:

- Désaulniers és Bigras [1998] quebeci feldolgozóipari kisvállalati interjúkkal elemezték a logisztikai szövetségeket, melyekben az öt kulcsstratégiát különböztettek meg. Ezek a méretgazdaságosság (pl. kiegészítő vagy versenyző termékek azonos célpontra szállítása), a disztribúciós hálózathoz történő hozzáférés, a speciális szállítás nyújtása, a helyi piac ismerete és az exportpiacokon történő termelés voltak. Az együttmüködések hatására a logisztikai teljesítmény nőtt ugyan, de a szövetségek gyakran az exporthoz kötődő indirekt logisztikai költségeket

52 A készletgazdálkodás, a kiszolgálási színvonal és a logisztikai költségek döntéstámogatása, a terméknyilvántartás, az áruátvétel, a belső folyamatok, a kiszállítási folyamat támogatottsága és a raktárinformatikai alrendszerek integráltsága terén. 
emelték, például az oktatás révén. A kilenc vállalat közel fele több partnerségben is részt vett.

- Morrissey és Pittaway [2004] hat brit műanyag-fröccsöntő kisvállalkozás beszerzését vizsgálta, melyeket azért választottak ki, mert a beszállítók monopolisták és a vevők erős profitmaximalizálók voltak. A vizsgált KKV-k vonakodtak beszerzési konzorciumba tömörülni a versenytársaikkal, és szkeptikusan kezelték az együttmüködést, mert szerintük a felszín alatt az ellenséges taktikák megmaradnak. A kutatók azt találták, hogy a kisvállalkozásoknál a tulajdonosmenedzserek eltérő motivációi (pl. életstílus, függetlenség) miatt a profitmaximalizáláson alapuló racionális modell nem müködik, ami a beszerzési irodalomban is felbukkanó együttmüködési javaslatot megkérdőjelezte.

\subsubsection{További eszközök, módszerek}

Kummer [1995] a KKV-knél alkalmazott logisztikai eszközök ismeretét és alkalmazását is vizsgálta. Ezek közül az útvonaltervezés, ABC elemzés és létesítmény berendezés (layout) tervezése volt a leggyakoribb, az értéklánc-elemzés és az XYZ elemzés pedig a legritkább.

15. ábra: Logisztika eszközök alkalmazása a német KKV-knél

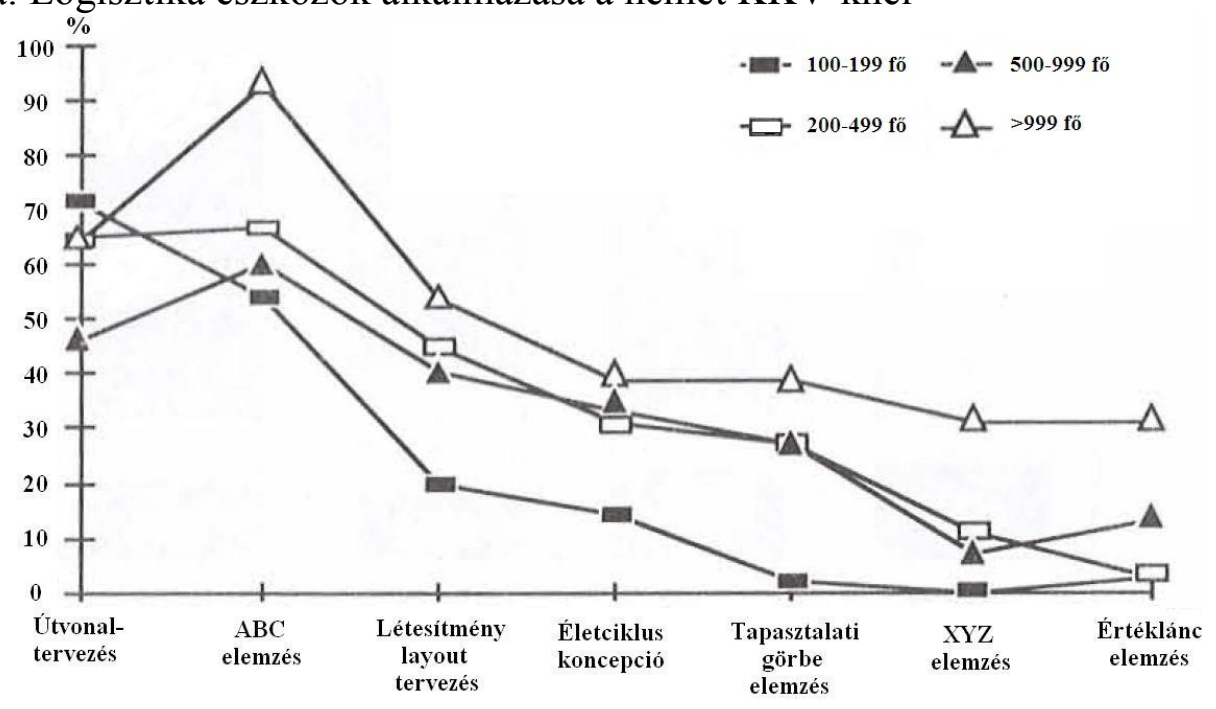

Forrás: Kummer [1995] p. 54.

A finn vállalkozások logisztikai helyzetének felmérése megmutatta, hogy a KKV-k és a nagyvállalatok fejlesztési igényei az ellátási lánc átláthatóságának növelése és a vevőkiszolgálás javítása tekintetében különböznek egymástól. 
16. ábra: A legfontosabb finn fejlesztési igényeik vállaltméret szerint

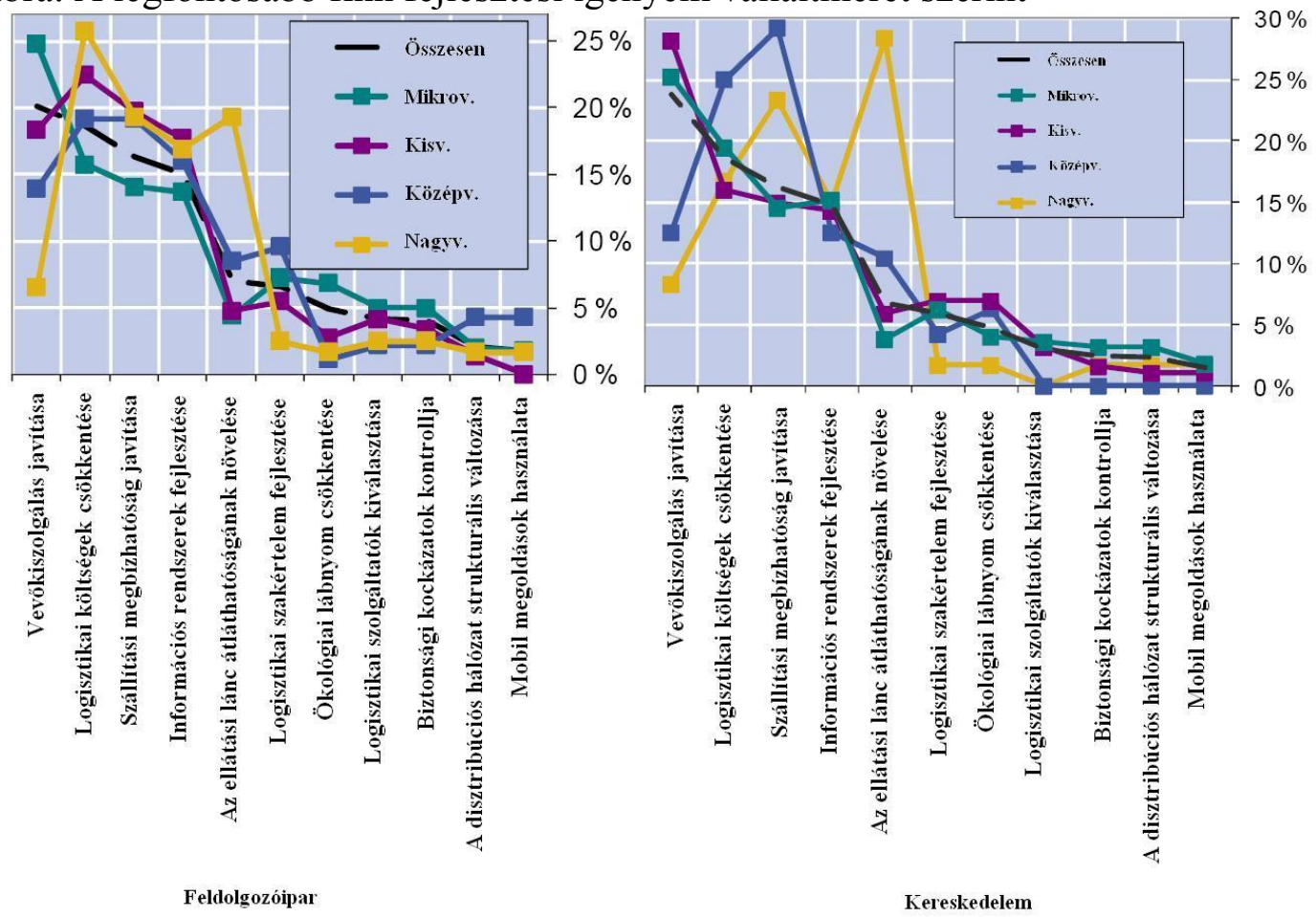

Forrás: Solakivi et al. [2009] p. 84. és p. 87. alapján

Scully és Fawcett [1994] igazolta, hogy a kisvállalatok elkötelezettek a nemzetközi beszerzés iránt, sőt ezt sikeresen végzik. A kisebb nemzetközi orientáció, kevesebb tényezőn alapuló döntések, és kevesebb haszon észlelése miatt a kisvállalatok nemzetközi beszerzése korlátozottabb szinten áll, de az azonnali specifikus problémákat/lehetőségeket gyorsabban érzékelik. A szerzők szerint a kisvállalatok a nemzetközi beszerzés második lépcsőjén (reaktív, tranzakció-orientált) állnak. Quayle [2002c] szerint a helyiről globális beszerzésre való áttérést - a vele járó kockázatok (pl. tudásvesztés) miatt - óvatosan kell előkészíteni. Overby és Servais [2005] 105 dán kisvállalat nemzetközi beszerzési gyakorlatát vizsgálva kimutatta, hogy 93,8\%-uk legalább két külföldi országból szerez be, de beszállitó-választásuk legfőbb szempontja az ár és a minőség, nem pedig a helyi beszállitók hiánya.

Gelinas és Bigras [2002] a quebeci kisvállalatok könnyü használati és értelmezhetőségi igényeit figyelembe vevő logisztikai teljesítményellenőrző módszertant, illetve egy arra épülő ingyenes szoftvert fejlesztett ki az ezredfordulón. Ez a kisvállalat jellemzőit, stratégiai és logisztikai céljait, indikátorait és azok konzisztenciáját vizsgálta. 
Nabhani és Shokri [2009] egy angol élelmiszerkereskedő disztribúciójának hat szigma módszerrel történő javítását mutatta be. A rakodás és a raktárelrendezés módosításával a kisvállalkozás csökkentette az eljutási időket, és a hibák számát, ezáltal növelte a vevői elégedettséget.

Összegzésként elmondható, hogy az eszközök közül a logisztika magas adat- és számításigénye miatt az informatikaiak kapnak nagyobb figyelmet. Ezek a KKV-k körében is terjednek, bár a beruházásigényük miatt elsősorban az olcsóbb és egyszerübb változatok a jellemzőek. (Halley és Guilhon [1997]; Pearson és Semeijn [1999]; Roy et al. [2002]; Gelinas és Bigras [2004]; Szabó [2005]; Vízhányó [2006]; Solakivi et al. [2009]; Gelei és Nagy [2010]). Désaulniers és Bigras [1998] szerint a méretgazdaságosság, a disztribúciós hálózathoz történő hozzáférés, a speciális szállítás nyújtása, a helyi piac ismerete és az exportpiacokon történő termelés az öt kulcsstratégia a logisztikai szövetségekben. A KKV-k kis méretéböl fakadó problémák kezelésére a logisztikai együttmüködést más szerzők is javasolják (Finley [1984]; Hudson és McArthur [1994]; Chikán et al. [2007]), bár a tulajdonos-menedzserek a profitmaximalizáláson alapuló racionális modelltől eltérő motivációi miatt a gyakorlatban ez nem müködött. (Morrisey és Pittaway [2004]; Tóth [2009]) A hagyományos logisztikai módszereket egyedül Kummer [1995] vizsgálta és arra jutott, hogy az útvonaltervezés, az ABC elemzés és a létesítmény berendezés tervezése volt a leggyakoribb. A kutatások szerint a kis- és középvállalkozások végeznek nemzetközi beszerzést (Scully és Fawecett [1994]; Quayle [2002c]; Overby és Servais [2005]), illetve a hat szigma módszer is alkalmazható az esetükben. (Nabhani és Shokri [2009])

\subsection{További logisztikai kutatások}

La Londe szerint (idézi Harrington [1995] p. 56.) a kisvállalatok legnagyobb gondja, hogy megküzdjenek a növekedéssel, amely együtt járhat azzal, hogy a kiszállítások már nem történnek időben, elvesznek a készletek, és visszamaradt rendelések halmozódnak fel. A problémák megoldásához a kisvállalatok kevés logisztikai segítséget kapnak hagyományos forrásokból, az érdekeiket képviselő logisztikai szervezet nem létezik, kevés tanácsadó specializálódik rájuk (a magas árakat amúgy sem tudnák kifizetni). (Harrington [1995]) 
Bagchi és Virum [2000] kimutatta, hogy a kis- és középvállalkozások számára nehéz a logisztikai képességfejlesztés és annak versenyeszközként történő alkalmazása, mivel korlátozottak az erőforrásaik és egyszerre kényszerülnek arra, hogy jobb logisztikai színvonalat nyújtsanak, és hogy kereskedelmi partnereikkel közeli kapcsolatban maradjanak.

Chikán et al. [2007] szerint a mikrovállalkozások egy jelentős része nem végez „logisztika-intenzív” tevékenységet, beszerzéseik a háztartásokéhoz hasonlatosak. A kis- és középvállalkozások tekintetében:

- a kategória „alsó” részében lévő vállalkozások logisztikai „rádiusza” lokális, piacukat a helyi sajátosságok határozzák meg, és érintettek, de nem feltétlenül érdekeltek a logisztikai hálózatok adta piacra jutási lehetőségekben.

- A „középső” és „felső” kategóriákba tartozó vállalkozások logisztikai intenzitása az alaptevékenységüktől függ, és alapvetően érdekeltek lehetnek a logisztikai hálózatokba történő bekapcsolódás.

Egy kutatás (Hutchinson et al. [2009]) a logisztikát a kiskereskedő kisvállalkozások nemzetköziesedésének külső korlátai közé sorolta. Sajnos kevés kutatás foglalkozik a kis- és középvállalkozások ezen aspektusával, holott kevés nemzetközibb tevékenység van, mint a logisztika. E probléma egy szük szegmensének feltárására törekedtem azon kutatásommal (Gecse [2009]), mely a Doing Business Index két, a kis- és középvállalkozások logisztikájához közvetetten kapcsolódó mutatóját hasonlította össze a V4-ek, Ausztria és Románia esetében:

- Egy középvállalkozás ${ }^{53} 1300 \mathrm{~m}^{2}$-es általános célú raktár engedélyezési eljárásainak száma 2008-ban a vizsgált országokban 13-36, időigénye 180-308 nap, költségigénye pedig az adott ország egy före jutó jövedelmének 10,3 és 137,0\% közötti értékeket vett fel.

- Egy középvállalkozás 20 lábas konténerének, az adott ország által leginkább használt kikötőbe történő eljuttatásához szükséges költség és idö tekintetében jelentős volt az eltérés (lásd a 17. ábra). Egy osztrák középvállalkozás konténerének teljes eljuttatási ideje export esetén 2008-ban például 11 nappal volt rövidebb, mint

\footnotetext{
${ }^{53}$ A módszertan szerint legalább 60 fös.
} 
magyar versenytársáé. A jelentős különbség elsősorban az adminisztrációs elemek különbségéből fakadt.

17. ábra: Közép-kelet-európai országok középvállalkozásainak konténereljuttatási ideje, költsége (2005-2008)

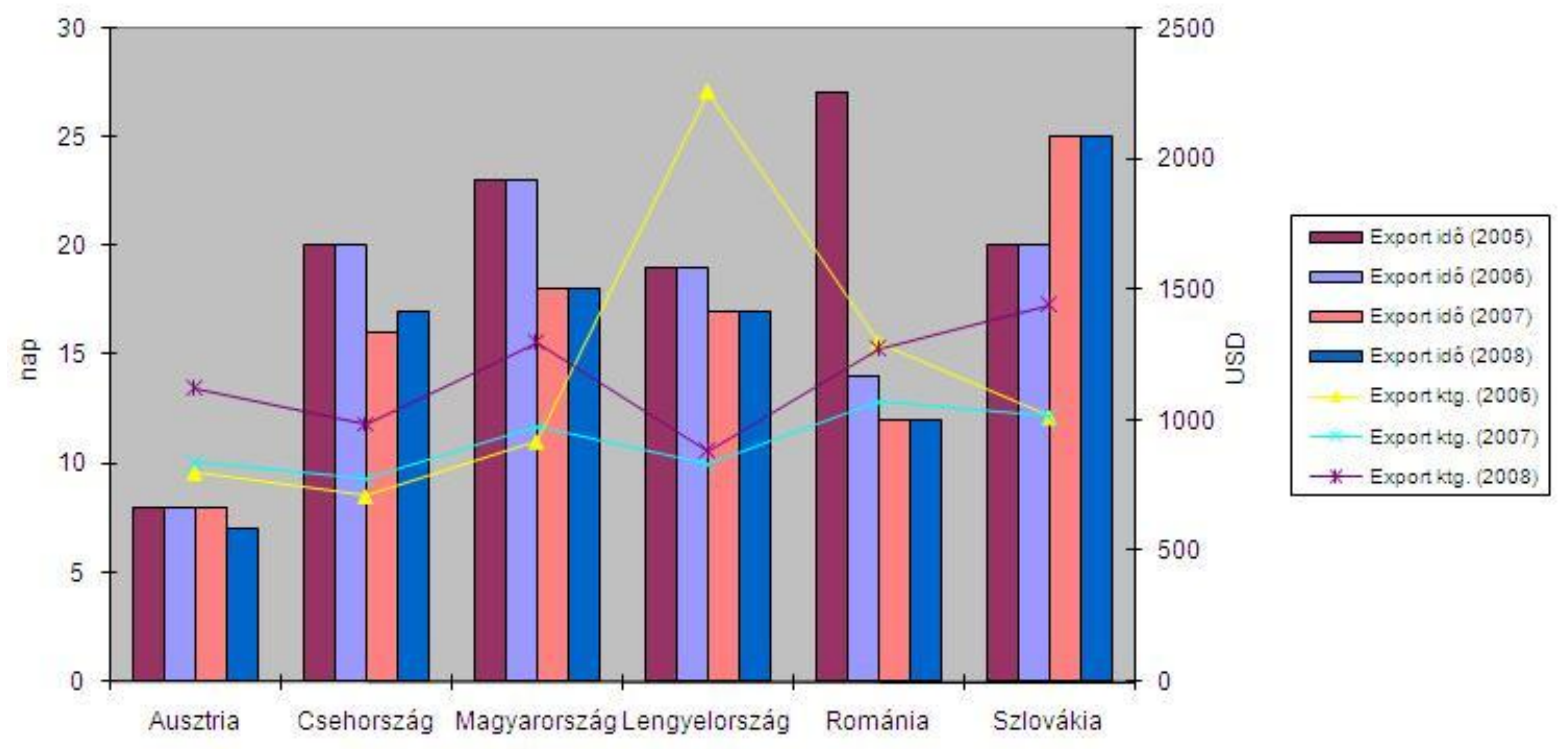

Forrás: Gecse [2009] p. 25. 


\subsection{A szakirodalom feldolgozás összefoglaló következtetései}

A kis- és középvállalkozások logisztikai gyakorlatát 20-25 éve kezdték el mélyebben vizsgálni, de a kutatások száma még mindig alacsony. A zömében csak a helyi nyelven (pl. francia, német, finn, norvég) elérhető, gyakran a „szürke” irodalomba tartozó kutatások eredményei nehezen voltak hozzáférhetőek, egyes esetekben pedig a vizsgált KKV-k tiltották meg a nyilvánosságra hozatalukat. A KKV-k logisztikai kutatási eredményeinek összehasonlítása, általánosítása nehézségekbe ütközött, mivel a kis- és középvállalkozások száma igen nagy, a logisztika komplex, sem a KKV-k, sem pedig a logisztika értelmezése ${ }^{54}$ nem egységes. A kölcsönös ismeretlenség miatt egymásra többnyire csekély hatással bíró kutatások között esettanulmányokat és akár 2705 vállalkozásra kiterjedő felméréséket is lehetett találni, az ágazatokat tekintve pedig a feldolgozóipar volt a leginkább vizsgált, melyet a kereskedelem, és az outsourcing kétoldalú (megbízó-igénybevevő) vizsgálata miatt a logisztikai szolgáltatók követtek. A mezőgazdasági, építőipari és a szolgáltató kis- és közepes vállalkozások logisztikájának vizsgálata szinte teljes mértékben hiányzott. A leggyakrabban kutatott területnek a logisztikai eszközök, a teljesítmény és azon belül is a költségszintek, illetve a tevékenységkiszervezés $(22,21$, illetve 18 kutatás) számított, melyet a logisztika jelentőségét megítélő és szervezeti-koordinációs-képzési felmérések követtek (13, illetve 10 felmérés). A logisztikai stratégiát pedig szinte alig vizsgálták.

A „Finland State of Logistics” kivételével hiányoztak a longitudinális kutatások, a finn, quebeci és német felmérésektől eltekintve pedig a szisztematikus vizsgálatok, mely vélhetően a felmérések nehézségeire (pl. alacsony válaszadási hajlandóság, reprezentativitás elérésének nehézsége) és az elért csekély információtartalmú eredményekre vezethetők vissza. A 14. táblázatban összefoglalt kutatások döntő többségében viszonylag alacsony szintủ matematikai-statisztikai módszertant (pl. leíró statisztikák) használtak.

A kutatásokat általában nem kötötték elméletekhez, mely részben a logisztika interdiszciplináris jellegéből, részben gyakorlati jellegéből fakadt.

A kutatási eredményeinek apró mozaikjai azt sugallják, hogy a kis- és középvállalkozások logisztikája lényegesen heterogénebb annál, mint a nagyvállalatokra vonatkozó vizsgálatok alapján gondolnánk.

\footnotetext{
${ }^{54}$ Egyaránt találni folyamat és tevékenységalapú megközelítéseket, illetve eleve adottnak vett logisztika felfogásokat.
} 
14. táblázat: A disszertációban feldolgozott KKV logisztikai kutatások a KKV értelmezés és a tématerület alapján

\begin{tabular}{|c|c|c|c|c|c|c|c|}
\hline Kutatás & Vizsgált vállalkozások száma, földrajzi elhelyezkedése és ágazata & 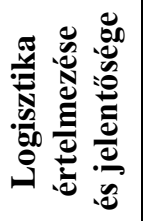 & 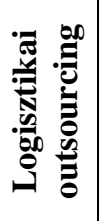 & 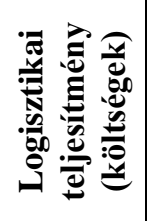 & 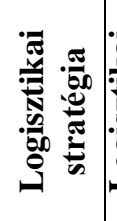 & 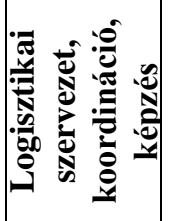 & 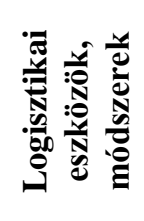 \\
\hline Solakivi et al. [2009] & 2705 finn feldolgozóipari, kereskedelmi és logisztikai szolgáltató & $\mathbf{x}$ & $\mathbf{x}$ & $\mathbf{x}(\mathbf{x})$ & & & $\mathbf{x}$ \\
\hline Naula et al. [2006] & 2255 finn feldolgozóipari, kereskedelmi és logisztikai szolgáltató & $\mathbf{x}$ & $\mathbf{x}$ & $\mathbf{x}(\mathbf{x})$ & & & $\mathbf{x}$ \\
\hline Solakivi et al. [2010] & $\begin{array}{c}1813 \text { finn feldolgozóipari, kereskedelmi, logisztikai szolgáltató, } \\
\text { tanácsadó }\end{array}$ & $\mathbf{x}$ & $\mathbf{x}$ & $\mathbf{x}(\mathbf{x})$ & & & $\mathbf{x}$ \\
\hline Ojala et al. [2007] & $\begin{array}{c}1234 \text { balti térségi feldolgozóipari, kereskedelmi, logisztikai } \\
\text { szolgáltató }\end{array}$ & $\mathbf{x}$ & $\mathbf{x}$ & $\mathbf{x}(\mathbf{x})$ & & & $\mathbf{x}$ \\
\hline Roy et al. [2002] & 688 kanadai feldolgozóipari, kereskedelmi & & & & & + & + \\
\hline Hovi és Hansen [2010] & 508 norvég feldolgozóipari, kereskedelmi és építőipari & & & (x) & & & \\
\hline Lea et al. [1996] & 461 norvég feldolgozóipari & & & $\mathbf{x}(\mathbf{x})$ & & & \\
\hline Töyli et al. [2008] & 424 finn feldolgozóipari, kereskedelmi & & & $\mathbf{x}$ & & & \\
\hline Halley és Guilhon [1997] & 400 kanadai és francia mezőgazdasági és élelmiszeripari & & + & + & + & + & + \\
\hline $\begin{array}{l}\text { Gelinas és Bigras [2004]; } \\
\text { Gelinas et al. [2000] }\end{array}$ & 353 kanadai feldolgozóipari & & + & & + & + & + \\
\hline Paik et al. [2009] & 332 dán és amerikai feldolgozóipari és szolgáltató & & & + & & + & \\
\hline Uhlig és Gelinas [1994] & 332 német feldolgozóipari és logisztikai szolgáltató & & + & & & & \\
\hline Gritsch [2001] & $\begin{array}{c}319 \text { magyar mezőgazdasági, feldolgozóipari, építőipari, kereskedelmi, } \\
\text { szolgáltató }\end{array}$ & * & & & & & \\
\hline Pearson és Semeijn [1999] & 301 amerikai & & + & & & & + \\
\hline Quayle [2002a] & 298 brit mezőgazdasági, feldolgozóipari, építőipari, szolgáltató & * & & & & & \\
\hline Quayle [2002b] & 232 brit mezögazdasági, feldolgozóipari, építőipari, szolgáltató & * & & & & & \\
\hline Solakivi et al. [2011] & 223 finn feldolgozóipari és kereskedelmi & & & $\mathrm{x}$ & & & \\
\hline Orfanos et al. [2006] & $\begin{array}{l}206 \text { görög mezőgazdasági, feldolgozóipari, építőipari, kereskedelmi, } \\
\text { szolgáltató }\end{array}$ & & & $\mathbf{x}$ & & $\mathbf{x}$ & \\
\hline Bentzen et al. [2000] & 202 dán feldolgozóipari és szolgáltató & & + & & & & \\
\hline $\begin{array}{l}\text { Hong et al. [2004a] és Hong } \\
\text { et al. [2004b] }\end{array}$ & 192 kínai feldolgozóipari & & $*$ & & & & \\
\hline Presutti [1988] & 166 amerikai feldolgozóipari & & & + & & + & \\
\hline Fodor [2005] & 134 magyar feldolgozóipari, kereskedelmi szolgáltató & & & & & & * \\
\hline Berr et al. [1990] & 128 német feldolgozóipari & - & & & & - & \\
\hline Haan et al. [2007] & 127 lengyel & & & & & $\mathbf{x}$ & \\
\hline
\end{tabular}




\begin{tabular}{|c|c|c|c|c|c|c|c|}
\hline Grando és Belvedere [2006] & 117 olasz feldolgozóipari & & & $\bar{x}$ & & & \\
\hline Murphy et al. [1999] & 116 amerikai & & + & & & & \\
\hline $\begin{array}{l}\text { Kummer [1992] és Kummer } \\
\text { [1995] }\end{array}$ & 111 német feldolgozóipari, építőipari, kereskedelmi & $*$ & $*$ & $(*)$ & * & $*$ & * \\
\hline Overby és Servais [2005] & 105 dán feldolgozóipari & & & & & & + \\
\hline Vörösmarty et al. [2010] & 104 magyar feldolgozóipari, kereskedelmi, szolgáltató & $\bar{x}$ & & & & & \\
\hline Campos-Garcia et al. [2011] & 99 mexikói feldolgozóipari & & & $(+)$ & & & \\
\hline Pressey et al. [2009] & 97 feldolgozóipari & & & & $\bar{x}$ & & \\
\hline Szabó [2005] & 79 magyar feldolgozóipari, kereskedelmi, szolgáltató & $*$ & & $(*)$ & & & $*$ \\
\hline Scully és Fawecett [1994] & 72 amerikai feldolgozóipari & & & & & & + \\
\hline Gelei és Nagy [2010] & 63 magyar feldolgozóipari és szolgáltató & & & & & & $\mathbf{x}$ \\
\hline Evans et al. [1990] & 54 amerikai feldolgozóipari & & $\mathbf{x}$ & & & & \\
\hline Pezzotta et al. [2006] & 48 német, olasz és magyar feldolgozóipari & & $\mathbf{x}$ & $\mathbf{x}(\mathbf{x})$ & & & \\
\hline $\begin{array}{l}\text { Bagchi és Virum [2000]; } \\
\text { Virum [1994] }\end{array}$ & 30 norvég feldolgozóipari & & & $\mathbf{x}(\mathbf{x})$ & & & \\
\hline Zheng et al. [2004] & 28 brit feldolgozóipar, építőipari és kereskedő & & & & $\mathbf{x}$ & & \\
\hline Vízhányó [2006] & 27 magyar feldolgozóipari, kereskedelmi, szolgáltató & $*$ & $*$ & $(*)$ & & & $*$ \\
\hline Desauliners és Bigras [1998] & 9 kanadai feldolgozóipari & & & & & & $*$ \\
\hline Morrisey és Pittayway [2004] & 6 brit feldolgozóipari & & & & & & $*$ \\
\hline Tökés [2010] & 6 magyar feldolgozóipari & & $\mathbf{x}$ & $\mathbf{x}$ & & & \\
\hline Chao és Shah [2010] & 4 tajvani feldolgozóipari & & $*$ & & & & \\
\hline Futakfalvi [2008] & 1 magyar kereskedelmi & & - & & & & \\
\hline Holter et al. [2008] & 1 brit feldolgozóipari & & - & & & & \\
\hline Nagy [2008] & 1 magyar élelmiszeripari & & - & & & & \\
\hline Tóth [2009] & 1 magyar nagykereskedő & & - & & & & \\
\hline Nabhani és Shokri [2009] & 1 brit élelmiszeripari & & & & & & - \\
\hline Wagner és Alderdice [2006] & 1 brit halászati & & & - & & & \\
\hline \multicolumn{2}{|c|}{ AZ ADOTT TERÜLETET VIZSGÁLÓ KUTATÁSOK SZÁMA ÖSSZESEN } & 13 & 22 & $21(14)$ & 5 & 10 & 18 \\
\hline
\end{tabular}

x: EU-s KKV meghatározás (250 fö és/vagy 50 millió $€$ alatt)

+: Észak-amerikai KKV meghatározás (500 fó vagy 50 millió \$ árbevétel alatt)

-: KKV meghatározása ismeretlen:

*: Egyéb KKV meghatározás

Forrás: saját szerkesztés 
A tanulmányozott szakirodalomban a szerzők többsége - egységes értelmezést feltételezve - a kis- és középvállalkozások logisztika értelmezését nem vizsgálta, azonban egyes kutatások (Kummer [1995]; Szabó [2005]; Vízhányó [2006]) rámutattak, hogy valójában az egyáltalán nem homogén. A logisztikát a KKV-k fontosnak tartották (Berr et al. [1990]; Kummer [1995]; Szabó [2005]; Vízhányó [2006]; Solakivi et al. [2009]; Vörösmarty et al. [2010]), bár egyes beszerzési kutatások (Quayle [2002a]; Quayle [2002b]) ennek ellentmondtak. A felmérések nem adtak egyértelmü választ arra, hogy a kis- és középvállalkozások milyen vállalkozásméret felett (20 fó, 200 fö, 1,5 milliárd Ft) kezdenek tudatosan foglalkozni a logisztikával. (Virum [1994]; Kummer [1995]; Gritsch [2001]; Vízhányó [2006])

A logisztikai tevékenységkiszervezési kutatásokból kevés általános következtetés vonható le. (Solakivi et al. [2011] p. 132.) A tevékenység-kiszervezéssel foglalkozó cikkek többsége nem vizsgálta az elméleti hátteret (Selviaridis és Spring [2007]), ha mégis, akkor leggyakrabban a tranzakciós költségek és az erőforrás-elmélethez köthető (alapvető) képességek, ritkábban más elméletek (pl. ügynök-, játékelmélet) merültek fel magyarázatként. (Ivanaj és Masson Franzil [2006]). A tranzakciós költségek és logisztikai outsourcing kapcsolatát vizsgáló kutatások elsősorban az eszköz/beruházásspecifikusságra fókuszáltak (Ivanaj és Masson Franzil [2006]; Aertsen [1993]; Maltz [1994]; Skjøtt-Larsen [2000]). Kállay és Imreh [2004] szerint a KKV-k körében a kiszervezett szolgáltatások szintje alacsony a méretgazdaságtalansági okok miatt túl magas tranzakciós költségek miatt. van den Berg [2009] ugyanerre jutott, bár szerinte a hagyományos, nagy volumenekre épülő outsourcing modell az infokommunikációs technológiák fejlődése miatt megváltozóban van. A más néven is vizsgált logisztikai tevékenységkiszervezés (pl. 3PL, szerződéses logisztika, logisztikai szövetség, alvállalkozásba adás) szintje az elmúlt években a felmérések szerint (pl. „Lieb sorozatok”, „Langley sorozatok”) folyamatosan nőtt, az egyeditől a komplexebb szolgáltatások felé mozdult el, és gyakoribb a fejlett, mint a fejlődő régiókban (Pezzotta et al. [2006]). Az adott logisztikai résztevékenységeket a KKV-k nem mindig szervezik ki teljes mértékben (Bentzen et al. [2000]; Vízhányó [2006]; Futakfalvi [2007]; Tóth [2009]). Ivanaj és Masson Franzil [2006], valamint Hong et al. [2004b] szerint a vállalatméret a logisztikai tevékenységkiszervezés egyik kontingencia-tényezője, bár Bardi et al. [1991] szerint ez nem egyértelmü. A logisztikai outsourcing kutatások a nagyvállalatok és KKV-k között szignifikáns különbségeket találtak (Evans et al. 
[1990]; Murphy et al. [1999]; Gelinas és Bigras [2004]), mely a nemzetközi kereskedelembe bekapcsolódás esetén (Murphy et al. [1995]; Pearson és Semeijn [1999]) ezek eltüntek. A kiszervezés előnyeit és hátrányait szinte kizárólag nagyvállalati cikkek vizsgálták, melyek Selviaridis és Spring [2007] szerint stratégiai, pénzügyi és müködési okokra bonthatók fel. A KKV-k logisztikai tevékenységkiszervezését elsősorban taktikai, mint stratégiai szempontból végezték (Chao és Shah [2010]), az erre vonatkozó döntés melletti és elleni érvek sorrendje változatos volt (Uhlig és Gelinas [1994]; Vízhányó [2006]). Egyes esettanulmányok (Futakfalvi [2007]; Nagy [2008]; Tóth [2009]) alapján a költségcsökkentési lehetőséget egyéb szempontok (pl. vevőkkel való személyes kapcsolat, a szolgáltatás időbeni és kapacitásbeli rugalmassága) felülírhatják. Egy angol esettanulmány (Holter et al. [2008]) azonban megmutatta, hogy megfelelő technikákkal a költségmegtakarítás érvényesíthető. Sajnos a KKV-k logisztikai tevékenységkiszervezése melletti és elleni érvek vizsgálatának módszertana a gyakoriságok összehasonlításán nemigen lépett túl.

Halley és Guilhon [1997] szerint a kisvállalatok logisztikai teljesítménye pénzügyi mutatók alapján relatíve fejletlen, azonban szervezeti indikátorokkal már egy fejlődő, értékteremtési szemszögből pedig integrált proaktív tevékenységnek volt tekinthető. Az eszközarányos megtérülésre gyakorolt hatást alapvetően a logisztikai költség, a logisztikai folyamatokra fordított idő csökkentése, ezek tökéletesítése és a vevőkiszolgálási célok felállítása magyarázta (Bagchi és Virum [2000]). A norvég és a görög KKV-k körében végzett kutatás szerint a logisztika közvetlenül befolyásolta a KKV-k teljesítményét. (Lea et al. [1996]; Orfanos et al. [2010]), bár Töyli et al. [2008] és Solakivi et al. [2011] szerint nincs statisztikailag megfigyelhető pozitív kapcsolat a logisztikai és pénzügyi teljesítmény között. Egy olasz kutatás szerint a klasztertag kisés középvállalkozások logisztikai válaszadási képessége jelentősen erősödött, azonban innovációs szempontból elmaradtak a ,független” KKV-któl. (Grando és Belvedere [2006]) A quebeci feldolgozóipari kisvállalatok körében az együttmüködés hatására a logisztikai teljesítmény nőtt, de ezzel együtt a logisztikai költségek is. (Désaulniers és Bigras [1998])

Módszertani nehézségei ellenére (az információhiány miatt becslésen alapulnak, költségkomponenseik nem egységesek és viszonyítási alapjuk eltérő) a logisztikai teljesítmény mérésénél a költségszintek kiemelt szerepet kapnak. Ezek gyakran tévesen 
összemosódnak a logisztikai kiadási és ráfordítási szintekkel. Elméleti szinten a logisztikai részköltségekből a szállítási költségek vizsgálata emelhető ki, mely von Thünen [1826], Samuelson [1952] és Krugman [1991] munkásságával épült be a közgazdasági gondolkodásba. A logisztikai költségeket makroszinten ökonometriai modellekkel (Rodrigues et al. [2005]; Klaus [2008]; Wilson [2009]; King [2010]) vagy vállalati statisztikák alapján (Elger et al. [2008]) becsülik. A felmérések szerint a KKV$\mathrm{k}$ az árbevételük vagy az összköltségük 22\%-a alatti logisztikai költségekkel rendelkeztek. (Bagchi és Virum [2000]; Szabó [2005]; Vízhányó [2006]; Solakivi et al. [2009]; Hovi és Hansen [2010]; Solakivi et al. [2010]; Campos-Garcia et al. [2011]) A logisztikai költségszintjével a legtöbb KKV nem vagy csak mérsékelten volt tisztában (Virum [1994]; Tempel és Meißner [2002]), vagy úgy vélték, hogy az nulla. (Berr et al. [1990]; Campos-Garcia et al. [2011]). A vállalat méretének növekedésével csökkenő logisztikai összköltség-arányra vonatkozó hüvelykujj-szabály Solakivi et al. [2010] szerint a középvállalkozások esetében nem igaz, mivel a növekedésből származó költségeik már vannak, ám a megfelelö méret kiaknázásához még túl kicsik. Lea et al. [1996] szerint a logisztikai összköltség az árbevétel emelkedésével közel azonos mértékben nőtt, mely kisebb mértékben az inputok hozzáadott értékének emelkedésével is bekövetkezett, a készletek forgási sebességének emelkedése viszont csökkentette a mértékét. A kutatók a hosszabb exportgyakorlattal rendelkező KKV-nál kisebb, a beszállítási problémákkal és a rövidtávú keresletcsökkenéssel szembesülőknél pedig magasabb logisztikai költségeket találtak (Lea et al. [1996]). Makroszinten (Harrington [1995]; Naula et al. [2006]; Hovi és Hansen [2010]) gyakran fogalmazzák meg célként a logisztikai költségek csökkentését, mely a vállalatoknál (Vízhányó [2006]) is megjelenik, jellemzően az integrálatlan logisztikával rendelkezőknél (Halley és Guilhon [1997]). A logisztikai költségcsökkentés hatása azonban limitált (Kummer [1995]). Fodor [2005] szerint a logisztikai információs rendszer bevezetésével nem a költségcsökkentéssel, hanem a vevőkiszolgálási színvonal növelésével, értek el előnyt. Solakivi et al. [2011] a finn KKV logisztikai tevékenységkiszervezése és a költségei között fordított U alakú összefüggést találtak.

A logisztika stratégiát a ,vállalati müködés vezérfonalának, a vállalati célokat és elérésük módját" (Chikán [2008] p. 187.) megfogalmazó vállalati stratégia függvényében lehet vizsgálni, mely Halley és Guilhon [1997] szerint gyenge vagy nem létezik. A tervezés során a kis- és középvállalkozások a logisztika versenyképességre 
gyakorolt hatását tekintették a legerösebbnek és a koncepciók bevezetésénél is a versenyelőny elérését célozták meg. A KKV-k az elö-logisztika, e tevékenység iránti érdeklödés, és a kezdő szint után jutottak el a professzionális szintü logisztikáig. (Kummer [1995]). A tulajdonos-menedzser és a vállalat környezetétől való függőségi viszonya alapján proaktív, reaktív és kifejlődő logisztikai stratégiát különböztethető meg (Halley és Guilhon [1997]). A szerzők szerint a kisvállalatot nem lehet arra kényszeríteni, hogy a logisztikát a stratégiai ügyei közé felvegye és a logisztikai stratégiát nem lehet jó vagy rossz kategóriákba sorolni.

A logisztika szervezeti megjelenésével, koordinációjával kapcsolatos kutatások sajnos nem lépnek túl a kontingencia-elmélet szervezet méretével kapcsolatos csekély információtartalmú következtetésein, bár azokat legalább empirikusan alátámasztják. A logisztika formalizáltan a kis- és középvállalkozásoknál többnyire nem jelenik meg, ha igen, akkor szétszórtan (Kummer [1995]; Roy et al. [2002]; Gelinas és Bigras [2004]). A logisztikai feladatokat alacsony szinten kezelik (Berr et al. [1990]; Kummer [1995]; Roy et al. [2002]; Paik et al. [2009]), a döntéshozatali szabályok tisztázatlanok (Kummer [1995]), a részfeladatokat informálisan koordinálják. (Heinrich és Felhofer [1985]) A KKV-k általában többfunkciós, logisztikával is foglalkozó alkalmazottainak képzettsége gyenge (Evans et al. [1990]; Tempel és Meißner [2002]; Ellegaard [2009]), oktatásuk alacsony szintü (Presutti [1988]; Berr et al. [1990]; Harrington [1995]; Gelinas és Bigras [2004]), bár van ennek ellentmondó felmérés is. (Halley és Guilhon [1997])

A logisztikai eszközök vizsgálata Klaus [2009] szerint Babbage és Taylor munkásságára vezethető vissza. A logisztikai tevékenység magas adat- és számításigénye miatt az eszközök közül az informatikaiak kapnak nagyobb figyelmet, mely a KKV-k körében is terjednek, bár a beruházásigényük miatt elsősorban az olcsóbb és egyszerübb változatok a jellemzőek. (Halley és Guilhon [1997]; Pearson és Semeijn [1999]; Roy et al. [2002]; Gelinas és Bigras [2004]; Szabó [2005]; Vízhányó [2006]; Solakivi et al. [2009]; Gelei és Nagy [2010]). A hagyományos logisztikai módszereket egyedül Kummer [1995] vizsgálta és arra jutott, hogy az útvonaltervezés, az ABC elemzés és a létesítmény berendezés tervezése volt a leggyakoribb. Désaulniers és Bigras [1998] szerint a méretgazdaságosság, a disztribúciós hálózathoz történő hozzáférés, a speciális szállítás nyújtása, a helyi piac ismerete és az exportpiacokon történő termelés az öt kulcsstratégia 
a logisztikai szövetségekben. A logisztikai együttmüködést a KKV-k kis méretéből fakadó problémáinak kezelésére más szerzők is javasolják (Finley [1984]; Hudson és McArthur [1994]; Chikán et al. [2007]), bár a tulajdonos-menedzserek a profitmaximalizáláson alapuló racionális modelltől eltérő motivációi miatt ez a gyakorlatban nem müködött. (Morrisey és Pittaway [2004]; Tóth [2009]) A kutatások szerint a kis- és középvállalkozások végeznek nemzetközi beszerzést (Scully és Fawecett [1994]; Quayle [2002c]; Overby és Servais [2005]), illetve a hat szigma módszer is alkalmazható az esetükben. (Nabhani és Shokri [2009]) 


\section{A kutatás hipotézisei}

A disszertációmban a magyarországi kis- és középvállalkozások logisztikai gyakorlatát vizsgáltam mélyebben. Ennek oka, hogy a kis- és középvállalkozások a közpolitikában előtérbe kerültek, de azok logisztikai funkcióját eddig kevéssé vizsgálták. Úgy gondolom, hogy a nagyvállalatokhoz hasonlóan a KKV-k logisztikai gyakorlatának megismerése és javítása hozzájárulhat e vállalkozási kör teljesítményének javításához és a magyar gazdaság dualitásának oldásához. Kutatásom az eddigi felméréseken a magasabb szintü matematika-statisztikai módszertannal, illetve a hipotézisek vizsgálatánál a reprezentatív minta felhasználásával lépett túl.

A kutatásom fó kérdése az volt, hogy a KKV-k logisztikája csak egy másodlagos vállalati funkciónak tekinthető, amellyel kapcsolatban nem szükségesek újabb kutatások, vagy egy olyan eddig elhanyagolt tevékenységről van szó, mely a KKV-k jobb vállalati teljesítményét segítheti elő. A szakirodalom alapján a kis- és középvállalkozások logisztikájának számos részterülete feltárásra vár, azonban gyakorlati megfontolások (pl. összehasonlíthatóság, a problémák számszerüsítése) alapján és a kutatási korlátok miatt elsősorban a KKV-k logisztikai tevékenységkiszervezésére, költségszintjeire és szervezeti elemeire fókuszáltam.

Kutatásom, melynek megfigyelési egységei a kis- és közepes vállalkozások, részben leíró, részben pedig magyarázó keresztmetszeti kutatásnak tekinthető.

Morrissey és Pittaway [2004] a kis- és középvállalkozások beszerzését vizsgálva jelezte, hogy a KKV-ket nem szabad homogén csoportként kezelni. Az első hipotézisemmel azt vizsgáltam, hogy milyen változók (kontingencia-tényezők) befolyásolják a kis- és középvállalkozások alábbi logisztikai jellemzőit:

- A KKV-k összköltségén belüli a logisztikai részköltségek és a logisztikai összköltség szintjét.

- Az egyes logisztikai résztevékenységek kiszervezésének arányait.

A szakértők számos kontingencia-tényezőt javasolnak erre, melyek közül a legtöbb kutatásban a vállalatméret (Kummer [1995]; Hong et al. [2004a]; Hong et al. [2004b]; Vízhányó [2006]; Ivanaj és Masson Franzil [2006]; Ojala [2007]; Solakivi et al. [2009]; 
Solakivi et al. [2010]) szerepel, igaz Bardi és Tracey [1991] szerint ez nem egyértelmü. Emellett számos egyéb tényező is felbukkan, például az ágazat, a termelés típusa (Hong et al. [2004]) vagy a tulajdonos-menedzser hozzáállása. (Arbaugh [2003]). Mindezeket azonban elméleti alapon vagy nem reprezentatív mintával vizsgálták. A fentiek alapján úgy vélem, hogy a kis- és középvállalkozások logisztikai összköltség- és részköltség szintjeire, illetve tevékenységkiszervezési arányaira alapvetően két kontingenciatényező a vállalatméret és az ágazat használható, melyek hatását külön-külön vizsgáltam.

H1a: A magyarországi kis- és középvállalkozások vállalati összköltségén belül a logisztikai részköltség és összköltség szintjeit leginkább a vállalkozásméret és az ágazat befolyásolja.

H1b: A magyarországi kis- és középvállalkozások logisztikai résztevékenységeinek kihelyezési arányát leginkább a vállalkozásméret és az ágazat befolyásolja.

A második hipotézisem a magyarországi kis- és középvállalkozások logisztikai tevékenységkiszervezése által generált jelentős, de csak nehezen kiaknázható keresletbővülést vizsgálta. Ezzel részben cáfolnám azt, hogy a logisztikai szolgáltatóknak a logisztikai kiszervezésben már csak csekély növekedési lehetőségei vannak, ahogyan azt a nagyvállalatok vizsgálata alapján például a „Lieb sorozatok”, és a „Langley sorozatok”) sugallják.

H2: A magyarországi KKV-k szállítási és raktározási igénye jelentős látens keresletbővülést jelent a hazai fuvarozóknak és a raktározási szolgáltatást nyújtó vállalkozásoknak.

A harmadik hipotézisben a KKV-k logisztikai tevékenységkiszervezési okait és azok összefüggéseit tártam fel. Az ezt vizsgáló kutatások kevés következtetést fogalmaztak meg, de három elem kiemelhető:

1. Halley és Guilhon [1997] szerint a logisztika a kisvállalatok alapvető képességének tünik, mely Bentzen et al. [2000] szerint a középvállalkozásokra már nem igaz.

2. Kállay és Imreh [2004] szerint az outsourcing alacsony szintjének hátterében a túl magas relatív tranzakciós költség áll. Ezt erösíti meg van den Berg [2009], Finley [1984] és ezt támasztják a méretgazdaságosság elérését célzó együttmüködési javaslatok (Hudson és McArthur [1994]; Désaulniers és Bigras [1998]; Chikán et 
al. [2007]), melyek az esettanulmányok szerint azonban nem müködnek. (Morrissey és Pittaway [2004]; Tóth [2009])

3. A kutatások és az elméleti háttér alapján feltételezhető, hogy a KKV-k logisztikai tevékenységkiszervezésének fő okai a költségcsökkentés, az alapvető képességekre fókuszálás és a rugalmasság. (Uhlig és Gelinas [1994]; Vízhányó [2006])

Ezt követően McIvor kiszervezési általános modelljének a 18. ábra szerinti a KKV-k logisztikájára alakított változatának alkalmazhatóságát vizsgáltam. Ez a változat az eredeti modellhez képest nem tartalmazza a releváns értéklánc-tevékenységek értékelését, a felmerülő veszélyeket pedig a szolgáltatóktól való függőségre egyszerüsíti le.

A vizsgálatokat csak a nagyobb logisztikai tevékenységkiszervezési aránnyal bíró ágazatokra végeztem el, mivel a szolgáltatók szempontjából ezek az érdekesek.

18. ábra: Logisztikai tevékenységkiszervezés döntési modellje

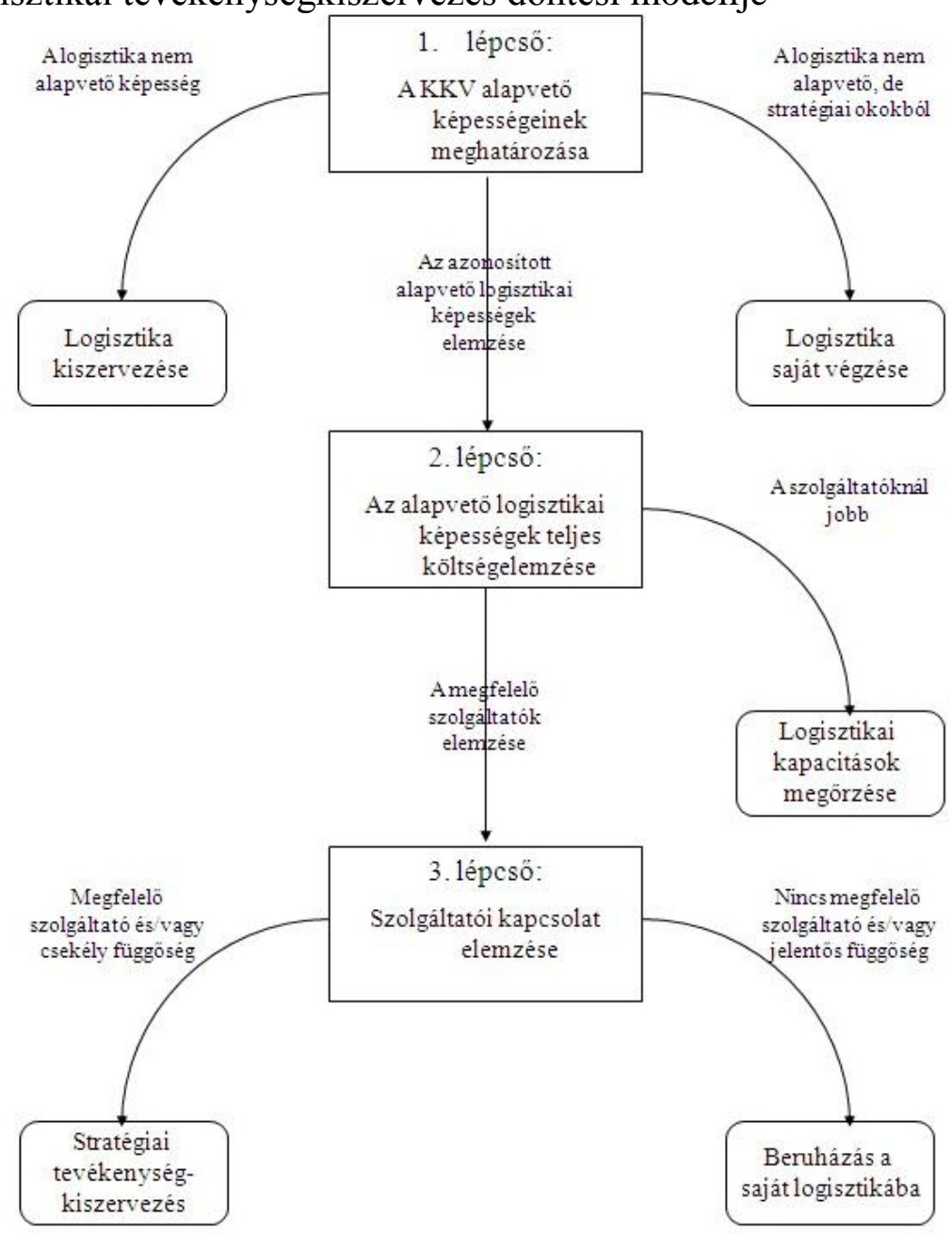

Forrás: McIvor [2000] alapján saját szerkesztés 
H3a: A magyarországi középvállalkozások a logisztikai résztevékenységeiket, a mikroés a kisvállalkozásoknál kisebb arányban tekintik alapvető képességüknek és kiszervezésüknél kisebb arányban szembesülnek magas tranzakciós költségekkel.

H3b: A magyarországi kis- és középvállalkozások logisztikai tevékenységkiszervezését elsősorban a költségcsökkentés, az alapvető képességekre fókuszálás és a rugalmasság magyarázza.

H3c: A magyarországi kis- és középvállalkozások egyes logisztikai résztevékenységkiszervezésének meghatározásához McIvor modellje jól használható.

A negyedik hipotézisem a KKV-s felmérésekben (Evans et al. [1990]; Pearson és Semeijn [1999]) és az esettanulmányokban (Futakfalvi [2007]; Nagy [2008]; Tóth [2009]) megjelenő logisztikai szolgáltatói teljesítményértékelési szempontokat vizsgálta, ami a KKV-k racionális döntését feltételezte.

H4: A magyarországi kis- és középvállalkozások logisztikai szolgáltatójuk teljesítményét a költségcsökkentés, a szolgáltatásminőség és a felmerült problémák alapján ítélik meg.

Az ötödik hipotézis a kis- és középvállalkozások - önértékelés szerinti - vállalati teljesítménye/sikeressége és a logisztikai rendszerének hatékonysága/teljesítménye, valamint előbbi és az igénybevett logisztikai szolgáltatás minősége közötti kapcsolatot vizsgálta. Egyes kutatások bizonyos logisztikai elemek és a vállalati teljesítmény között összefüggést találtak (Lea et al. [1996]; Orfanos et al. [2010]), de Töyli et al. [2008] és Solakivi et al. [2011] szerint nincs statisztikailag megfigyelhető pozitív kapcsolat a logisztikai és a vállalati (pénzügyi) teljesítmény között.

H5a: A magyarországi kis- és középvállalkozások teljesítménye és logisztikai rendszerük hatékonyága között nincs kapcsolat.

H5b: A magyarországi kis- és középvállalkozások teljesítménye és az általuk igénybe vett logisztikai szolgáltatás színvonala között nincs kapcsolat.

A hatodik hipotézis azt vizsgálta, hogy a magyarországi KKV-k különböző vezetői az összvállalati müködés sikere szempontjából a logisztikai jellegü müködési területeknek (beszerzés, logisztika, készletgazdálkodás) másodlagosnak tekintik. A logisztikainál nagyobb számú, a KKV-k beszerzését vizsgáló kutatás és Kummer [1995] felmérése 
alapján várhatóan a prioritást a beszerzés kapja, melynek jelentősége (Quayle [2002a]; Qualye [2002b]) elmarad a többi funkcióétól, igaz Vörösmarty et al. [2010] ezt cáfolták. H6: A magyarországi KKV-k vezetőinek beszerzés-prioritású logisztika felfogása van, a beszerzés, a készletgazdálkodás és a logisztika jelentősége elmarad a többi funkcionális részterületétől.

\section{Kutatásmódszertan}

A kutatásomhoz kvantitatív analízist használtam, mellyel a hipotézisek helytállóságát teszteltem. Kutatási módszerként a társadalomtudományokban leggyakrabban alkalmazott kérdőíves felmérést alkalmaztam, mely nagy alapsokaság jellemzőinek leírására, részletekbe menő elemzésre ad módot és a témától függően jól általánosítható. (Babbie [1999]) A kérdőíves felmérésnek Malhotra [2002] szerint a keresett információt adekvát kérdések formájában kell megfogalmaznia, együttmüködésre kell motiválnia a válaszadót, és a válaszadási hibákat minimalizálnia kell. A kérdőívezésre az ugyanúgy feltett kérdések miatt túlzott a standardizáltság, az alacsony érvényesség és a magas megbízhatóság jellemzö.

\subsection{Felhasznált adatbázisok}

Kutatásomhoz két adatbázist használtam fel:

- A „Vállalkozások helyzetének felmérése” 2009. szeptember-októberi adatfelvételét, melynek legnagyobb elönye a reprezentativitás és a nagy mintaméret. Ehhez köthetők a minta hátrányai is: a nagyobb méretü KKV-k száma alacsony, a nagy mintaméretre pedig egyes statisztikák érzékenyek. A kizárólag a magyarországi kisés középvállalkozásokra kiterjedő adatbázis a nagyvállalatokkal történő összehasonlítást nem tette lehetővé, emellett az adatbázis viszonylag kevés, összesen 68 kérdésre épült.

- A KKV-ket és nagyvállalatokat egyaránt tartalmazó „Versenyben a világgal” 2009 áprilisa és novembere között végzett adatgyüjtését, mely kiegészítette az előzőt. Annál kisebb elemszámú és nem reprezentatív, de nagyvállalatokat is tartalmazott, a vizsgálatában pedig jóval mélyebb volt. A „Vállalkozások helyzetének felmérése” adatbázissal szemben ennek a korábbi adatfelvételeinél $(1996,1999,2004)$ is szerepeltek logisztikai kérdések. 


\subsection{1. „Vállalkozások helyzetének felmérése 2009"}

A Magyarországon 1996-tól készült kis- és középvállalkozások helyzetével foglalkozó jelentések kialakítását 2002-től közel kétezer kis- és közepes vállalkozásra kiterjedő, reprezentatív mintán alapuló kérdőíves vizsgálat segítette. Ennek alapját 2009-ben a társas vállalkozások esetében a Complex Céghírek, az egyéni vállalkozások esetében a Belügyminisztérium Központi Adatfeldolgozó és Nyilvántartó Hivatalának adatbázisa jelentette. A felvétel Budapestre és Magyarország különböző helyzetü régióit jól reprezentáló négy megyére (Békés, Hajdú-Bihar, Győr-Moson-Sopron, Somogy) terjedt ki. A véletlen minta a vállalkozások területi eloszlásával arányosan az SPSS statisztikai program segítségével a Nemzeti Fejlesztési és Gazdasági Minisztérium munkatársai alakították ki, melyben a túlzott szerepeltetés elkerülése érdekében a relatíve homogén egyéni vállalkozói körből kisebb elemszámot választottak ki. A részminták standard hibája 95\%-os megbízhatósági szinten az egyéni vállalkozók esetében legfeljebb $\pm 2,04$, a társas vállalkozások esetében $\pm 1,33 \%$ volt. A drágább személyes kikérdezések mellett a postai úton történő felmérés rossz hatékonysága (6-15\%-os visszaküldés) és a megbízhatóság fokozása miatt döntöttek. (NFGM [2009]) A nyilvántartásokból kiválasztott címek megtalálásának nehézségei, és a vizsgálattól való elzárkózás miatt a 2009-es adatfelvétel során a kérdezőbiztosok nem saját ismeretségi körükből, hanem a kialakított két pótmintából tudtak hasonló jellemzővel rendelkező más vállalkozásokat megkeresni. A 2009-es felmérés mintamegoszlása a 15. táblázatban látható.

15. táblázat: „Vállalkozások helyzetének felmérése 2009” gazdasági ágak és létszám szerinti mintamegoszlása $(\mathrm{db})$

\begin{tabular}{|l|c|c|c|c|c|}
\hline & 0 fö & 1-9 fö & 10-49 fó & 50-249 fö & Összesen \\
\hline Mezőgazdaság & 39 & 37 & 5 & 2 & 83 \\
\hline Feldolgozóipar & 26 & 29 & 10 & 3 & 68 \\
\hline Energiaszolgáltatás & 11 & 6 & 0 & 1 & 18 \\
\hline Építőipar & 110 & 74 & 10 & 1 & 195 \\
\hline Kereskedelem & 281 & 315 & 16 & 4 & 616 \\
\hline Szolgáltatás & 283 & 190 & 14 & 2 & 489 \\
\hline Közösségi szolgáltatás & 362 & 154 & 14 & 5 & 535 \\
\hline Összesen & 1112 & 805 & 69 & 18 & 2004 \\
\hline
\end{tabular}

Forrás: saját szerkesztés

A felmérésbe 2009-ben a KKV-k logisztikáját érintő, korlátozott számú kérdés beépítésére kaptam lehetőségét, melyet minden szervezet számára ugyanúgy alakítottam 
ki. ${ }^{55}$ A kérdéseket korábbi kutatások alapján, az összehasonlíthatóság igényének szem előtt tartásával elsősorban a „Finland State of Logistics” kérdései alapján készítettem el, mivel Finnország hazánkhoz hasonlóan kis, nyitott gazdaság, a felmérést több alkalommal nagy mintán végezték el, ráadásul a legutolsót a felméréshez közeli időpontban. Emellett hasonló kérdőívet a balti-térség nyolc országának nyolc térségében (Észtország, Finnország déli része, Hamburg, Lettország, Litvánia, Mecklenburg-Elő Pomeránia, Pomeránia, Östergötland, Szentpétervár) is alkalmaztak. A felmérésbe beépítendő kérdésekről hazai logisztikai szakértők véleményét is kikértem.

A finn és balti kutatáshoz képest a vizsgálat kizárólagosan a logisztikai költségre és a tevékenységkiszervezésre szükítése mellett a fő különbség az volt, hogy:

- A logisztikai költségek viszonyítási alapjául az összköltséget választottam, mivel ez a becslésnél könnyebb viszonyítási alap, mint a leggyakrabban használt árbevétel, melynek használatát a „Vállalkozások helyzetének felmérése” kérdőívében amúgy is kerülték.

- A logisztikai tevékenységkiszervezés szintjénél - feltételezve, hogy kiszervezés esetén az alacsonyabb értékek dominálnak - egy max. 5\%-os kategóriát építettem be a felmérésbe.

A logisztika szó közvetlen használatát elkerültem, mivel a korábbi kutatásoknál többféle értelmezése (Kummer [1995]; Szabó [2005]; Vízhányó [2006]) jelent meg, amit a kérdőív (a végelges változatát lásd az 1. függelékben) öt mikrovállalkozásnál végzett próbatesztelése is megerősített. Emiatt a logisztikát a tevékenységek egységes ágazati osztályozási rendszere (TEÁOR) szerinti szállítás, rakománykezelés, raktározás, tárolás, csomagolás, szállítmányozás kategóriákra bontottam, mivel ezt a válaszadók jól értették, és:

- Részben kezelte a logisztika sokféle értelmezését, mivel azt átfedés-mentes, és viszonylag pontos definícióval rendelkező tevékenységekre/funkciókra bontotta.

- Segíti a nemzetközi összehasonlíthatóságot, mivel a TEÁOR európai szinten az egyéb statisztikai osztályozási rendszerekkel (pl. NACE, ISIC) harmonizált.

\footnotetext{
${ }^{55}$ A finn és balti kutatásokban a feldolgozóipari, kereskedelmi és logisztikai szolgáltató vállalkozások részben eltérö kérdőíveket kaptak.
} 


\subsection{2. „Versenyben a világgal 2009”}

A Budapesti Közgazdaságtudományi Egyetem Vállalatgazdaságtan Tanszéke által indított „Versenyben a világgal” kutatási programjának 1996-os adatfelvételét 1999-ben gyakorlatilag azonos, majd 2004-ben számos új kérdéssel frissülő kérdőív követte, mely szinte teljesen megegyezik a legutóbbi 2009-es felmérésével. A kutatásomhoz utóbbit használtam, melynek adatfelvételére 2009 áprilisa és novembere között került sor. A 313 vállalat összesen 1246 felsővezetőjétől (vezérigazgató, marketing, termelési és pénzügyi területek vezetői) származó információk adatbázisában a tisztítást követően 300 vállalat maradt, melyek megoszlása a 16. táblázatban látható:

16. táblázat: A „Versenyben a világgal 2009” felmérés gazdasági ágak és létszám szerinti mintamegoszlása $(\mathrm{db})$

\begin{tabular}{|l|c|c|c|c|c|c|}
\hline & 0 fö & $\mathbf{1 - 9}$ fö & $\mathbf{1 0 - 4 9}$ fö & $\mathbf{5 0 - 2 4 9}$ fö & $\begin{array}{c}\mathbf{2 5 0} \text { fö } \\
\text { felett }\end{array}$ & Összesen \\
\hline Mezőgazdaság & 0 & 0 & 4 & 8 & 1 & 13 \\
\hline Feldolgozóipar & 1 & 5 & 26 & 80 & 15 & 127 \\
\hline Energiaszolgáltatás & 0 & 0 & 0 & 3 & 3 & 6 \\
\hline Építőipar & 0 & 4 & 6 & 14 & 4 & 28 \\
\hline Kereskedelem & 1 & 10 & 13 & 29 & 4 & 57 \\
\hline Szolgáltatás & 3 & 13 & 15 & 20 & 16 & 67 \\
\hline Közösségi szolgáltatás & 0 & 0 & 0 & 2 & 0 & 2 \\
\hline Összesen & 5 & 32 & 64 & 156 & 43 & 300 \\
\hline
\end{tabular}

Forrás: saját szerkesztés

A termelés/szolgáltatás kérdőív 19 logisztika és ellátási lánc menedzsment, a kereskedelem/marketing 6 logisztikai szolgáltatási, a pénzügyi pedig 1 késztletforgásikészletezési kérdést tartalmazott. Emellett mindegyik kérdőív vizsgálta a szervezeti kapcsolatokat, köztük a logisztika összvállalati sikerbeli súlyát és más funkciókra gyakorolt hatását.

\subsection{Alkalmazott módszerek}

A kutatási hipotéziseim vizsgálatát az IBM PASW/SPSS 18.0. programcsomagjával végeztem el: a KKV-ket kizárólag létszám alapján határoztam meg: a vállalkozásokat 10 fő alatt mikro-, 10 és 50 fő között kis-, 50 és 250 fő között középvállalkozásoknak tekintettem. A vizsgálatból az alkalmazottal nem rendelkező vállalkozásokat nem zártam ki, mivel eddig nem vizsgálták őket és a további kutatásokat megalapozó eredményekkel (pl. a lakosság logisztikai gyakorlata) szolgálhatnak. 
A hipotéziseim vizsgálatához használt változókat és módszereket összefoglalóan a 17. táblázat, a kapott eredményekkel együtt részletesen kifejtve pedig a következő fejezet tartalmazza.

17. táblázat: A kutatás során alkalmazott módszerek

\begin{tabular}{|c|c|c|}
\hline Hipotézis & $\begin{array}{c}\text { Adatbázisok és változók } \\
\end{array}$ & Módszerek \\
\hline- & $\begin{array}{l}\text { „Vállalkozások helyzetének felmérése 2009” } \\
5 ., 13 ., 30 ., \text { illetve megye, településtípus, 3., 4., 7., } \\
\text { 23., 26-29., 51. kérdésekhez kapcsolódó változók } \\
\text { 5., 17., 30., illetve megye, településtípus, 3., 4., 7., } \\
\text { 23., 26-29., 51. kérdésekhez kapcsolódó változók } \\
\text { „Versenyben a világgal 2009” kutatás } \\
\text { A1, A8, K51d-i. és K52a-c. kérdései }\end{array}$ & $\begin{array}{l}\text { Leíró statisztikák, } \\
\text { faktorelemzés, } \\
\text { varianciaelemzés, } \\
\text { Kruskal-Wallis, } \\
\text { Mann-Whitney } \\
\text { tesztek }\end{array}$ \\
\hline $\begin{array}{l}\text { H1a } \\
\text { H1b }\end{array}$ & $\begin{array}{l}\text { „Vállalkozások helyzetének felmérése 2009” } \\
5 ., 13 ., 30 ., \text { illetve megye, településtípus, 3., 4., 7., } \\
\text { 23., 26-29., 51. kérdésekhez kapcsolódó változók } \\
\text { 5., 17., 30., illetve megye, településtípus, 3., 4., 7., } \\
\text { 23., 26-29., 51. kérdésekhez kapcsolódó változók }\end{array}$ & $\begin{array}{l}\text { Kereszttábla- } \\
\text { elemzések }\end{array}$ \\
\hline $\mathbf{H 2}$ & $\begin{array}{l}\text { „Vállalkozások helyzetének felmérése 2009” } \\
\text { 4., 13.a-b, 17a-b. kérdésekhez kapcsolódó változók } \\
\text { Nemzeti Adó- és Vámhivatal társasági } \\
\text { adóadatbázis - } 2009 \text { Értékesítés nettó árbevétele, } \\
\text { összes költség és ráfordítás adata }\end{array}$ & $\begin{array}{l}\text { Leíró statisztikák } \\
\text { (átlagszámítás) }\end{array}$ \\
\hline $\begin{array}{l}\text { H3a } \\
\text { H3b } \\
\text { H3c }\end{array}$ & $\begin{array}{l}\text { „Vállalkozások helyzetének felmérése } 2009 ” \\
18 \mathrm{c} ., 19 \mathrm{~b}, 19 \mathrm{~g}, \quad 30 . \text { kérdésekhez kapcsolódó } \\
\text { változók } \\
18,19 . \text { kérdésekhez kapcsolódó változók } \\
17 \mathrm{a}, 17 \mathrm{~b}, 17 \mathrm{c} \text { és 18-19. kérdésekhez kapcsolódó } \\
\text { változók }\end{array}$ & $\begin{array}{l}\text { Kereszttábla- } \\
\text { elemzések, skálázás } \\
\text { Bináris logisztikus } \\
\text { regresszió }\end{array}$ \\
\hline H4 & $\begin{array}{l}\text { „Versenyben a világgal 2009” } \\
\text { A1, A8, K55, K56 kérdéshez kapcsolódó változók }\end{array}$ & Faktorelemzés \\
\hline $\begin{array}{l}\text { H5a } \\
\text { H5b }\end{array}$ & $\begin{array}{l}\text { „Versenyben a világgal 2009” } \\
\text { A1, V14j, V15 kérdéshez kapcsolódó változók } \\
\text { A1, V15, K52, K54 kérdéshez kapcsolódó változók }\end{array}$ & $\begin{array}{l}\text { Klaszterelemzés és } \\
\text { kereszttábla-elemzés }\end{array}$ \\
\hline H6 & $\begin{array}{l}\text { „Versenyben a világgal 2009” A1 változók és } \\
\text { M1 kérdésekhez kapcsolódó változók mind a négy } \\
\text { vezetői kérdőívből }\end{array}$ & $\begin{array}{l}\text { Összetartozó mintás t- } \\
\text { próba és Wilcoxon- } \\
\text { próba }\end{array}$ \\
\hline
\end{tabular}

Forrás: saját szerkesztés 


\section{Kutatási eredmények}

A disszertációban felhasznált két kutatás adatfelvétele 2009-ben történt, mely a gazdasági válság miatt nem tekinthető átlagos évnek. Ebben az évben a Központi Statisztikai Hivatal szerint a magyar folyó áras GDP az előző évhez képest 6,8\%-kal esett vissza, és a magyarországi vállalkozások logisztikáját közvetetten jelző indikátorok (pl. Baltic Dry Index, BVL logisztikai indikátora ${ }^{56}$ ) is a mélypontjukon voltak. Ugyanekkor jelent meg a Világbank egyre szélesebb körben elfogadott logisztikai versenyképességét mérő Logistics Performance Indexe, melyben Magyarország a korábbi pozícióján rontva az 52. helyezést érte el.

19. ábra: Európai országok rangsora a Logistics Performance Index alapján, 2009

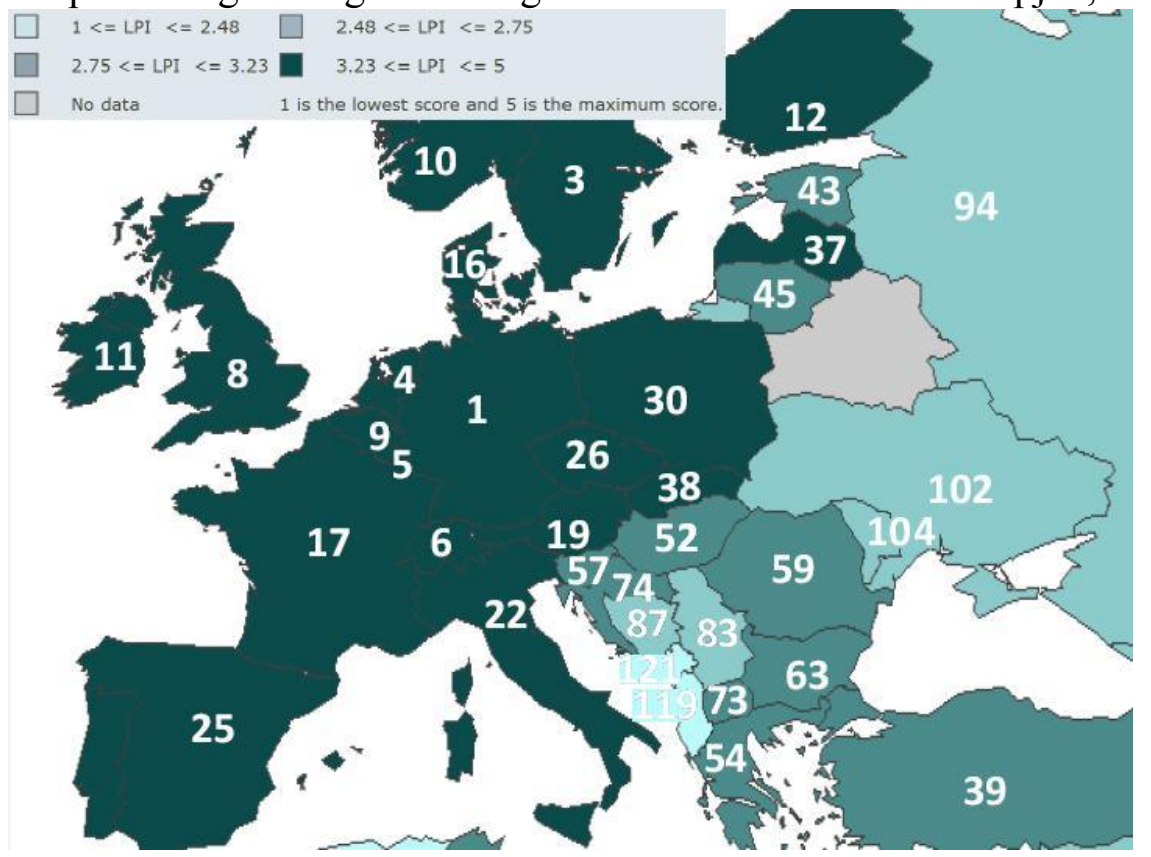

Forrás: Arvis et al. [2010] alapján

A hipotézisek vizsgálatát megelőzően a „Vállalkozások helyzetének felmérése 2009” logisztikai változóit vizsgáltam, mivel azokat még nem elemezték részletesebben. Ennek során a logisztikai költségszintek és kiszervezési arányok leíró statisztikái mellett megvizsgáltam azok eloszlásait, független változók szerinti szignifikáns különbségeit, valamint a köztük lévő összefüggéseket is.

\footnotetext{
${ }^{56}$ A Központi Statisztikai Hivatal adatai szerint 2009-ben a magyar külkereskedelem 23,22\%-a kötődött Németországhoz.
} 


\subsection{A „Vállalkozások helyzetének felmérése 2009” adatbázis logisztikai költségszint és outsourcing változóinak vizsgálata}

\subsubsection{Logisztikai költségszintek}

A „Vállalkozások helyzetének felmérése 2009” 13. (nyílt) kérdése keretében a kis- és középvállalkozások logisztikai részköltségeik szintjét ${ }^{57}$ egyesével jelölhették meg összköltségük százalékában. Ezek összeadásával számítottam ki a logisztikai összköltségszintet, melynek készlettartási tőkeköltség elemét a készletek beszerzési áras éves átlagos értékének és a Magyar Nemzeti Bank 2009. évi átlagos kamatlábnak ${ }^{58}$ a szorzataként határoztam meg.

A magyarországi KKV-k logisztikai összköltségének vállalati összköltségen belüli szintje 2009-ben 18,86\%-ot ért el, melyből a legnagyobb arányban a szállítási, a logisztikai adminisztrációs és a raktározási költség részesedett. Ezek közül a logisztikai adminisztrációs költségek magas szintje emelkedett ki. A minél nagyobb a vállalkozás annál kisebb a logisztikai költség hüvelykujjszabálynak ${ }^{59}$ éppen az ellenkezője teljesült, igaz a kis-, illetve a középvállalkozások száma viszonylag alacsony volt a mintában.

20. ábra: Magyarországi KKV-k logisztikai költségszintjei vállalatméret szerint, 2009

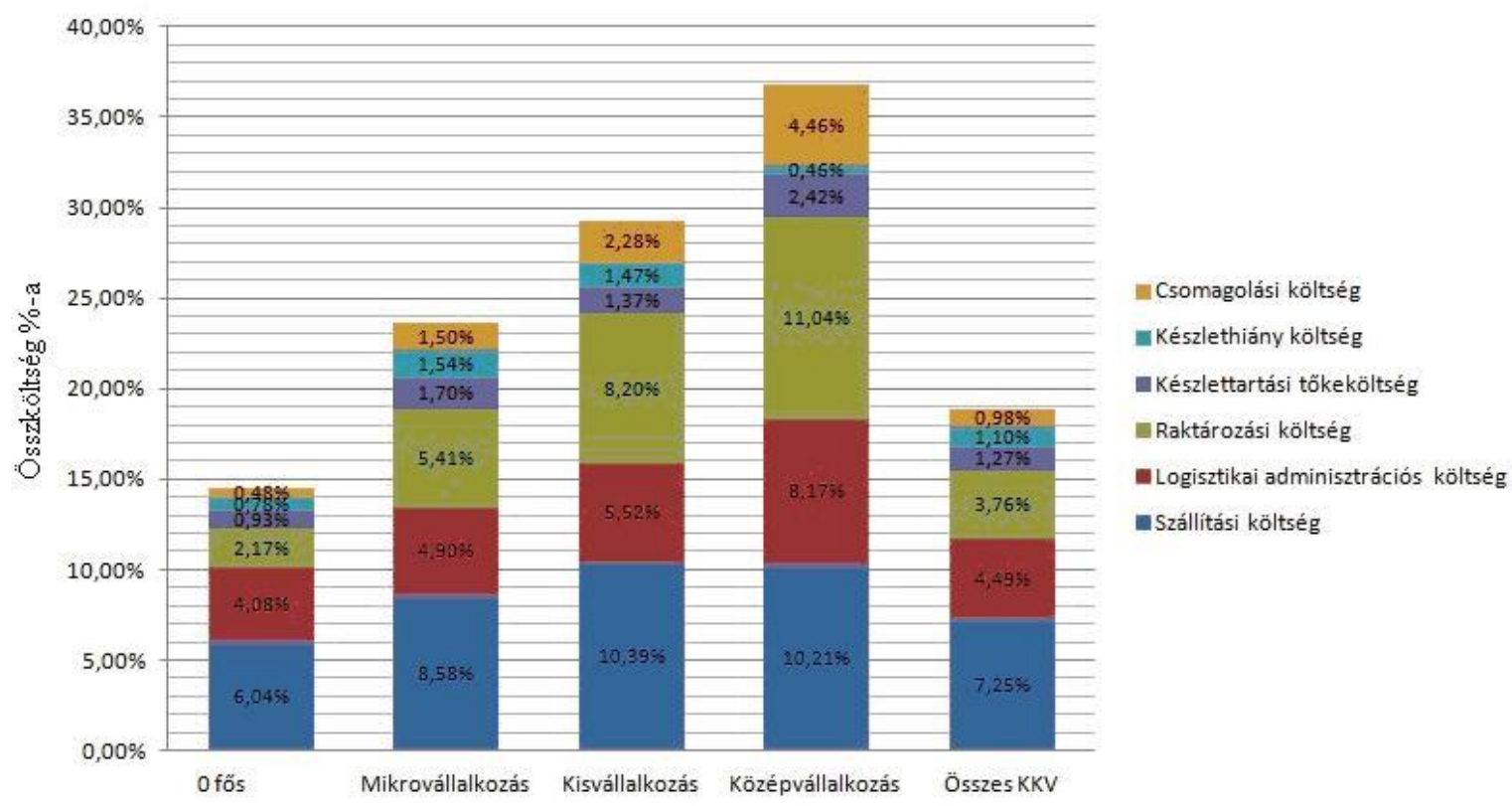

Forrás: saját szerkesztés

\footnotetext{
57 Szállítás és rakománykezelés, raktározás, tárolás (saját raktár működtetése vagy ilyen szolgáltatás igénybevétele), csomagolás, készletek éves átlagos értéke (beszerzési áron), készlethiány miatt megvalósult megrendelés, alacsonyabb termelés/szolgáltatás.

${ }^{58}$ Ertéke 8,63\%. A 2009-es év választásának oka az, hogy a kérdőívben a KKV-k költségbecslésüket erre az időszakra tették.

${ }^{59}$ Eltekintve, hogy az árbevétel alapon megállapított szabállyal szemben ez összköltség bázisú.
} 
A magyar KKV-k költségszintje vélhetően emelkedett a gazdasági-pénzügyi válság hatására, ugyanis a „Versenyben a világgal 2009” kutatás K51d-i. kérdései alapján a felmérést megelőző hároméves időszakban a logisztikai részköltségek valamennyi eleme nőtt. A logisztikai részköltségek ötfokozatú skálán felvett (jelentősen csökkent (1) ... jelentősen nőtt (5)) értékeinek átlaga a 18. táblázatban található.

18. táblázat: Egyes logisztikai részköltségek változásának 1-5 Likert-skálán mért értékeinek átlaga a 2009-et megelőző három évben

\begin{tabular}{|l|c|c|c|c|}
\hline & $\begin{array}{c}\text { Szállítási } \\
\text { költség }\end{array}$ & $\begin{array}{c}\text { Raktározási } \\
\text { költség }\end{array}$ & $\begin{array}{c}\text { Készletezési } \\
\text { költség }\end{array}$ & $\begin{array}{c}\text { Egyéb } \\
\text { logisztikai } \\
\text { költségek }\end{array}$ \\
\hline Mikrovállalkozás & 3,31 & 3,75 & 3,66 & $3,41-3,56$ \\
\hline Kisvállalkozás & 3,74 & 3,54 & 3,45 & $3,26-3,41$ \\
\hline Középvállalkozás & 3,65 & 3,50 & 3,49 & $3,30-3,36$ \\
\hline Összesen & 3,63 & 3,54 & 3,50 & $3,33-3,38$ \\
\hline
\end{tabular}

Forrás: saját szerkesztés

A „Vállalkozások helyzetének felmérése 2009” adatbázis alapján a magyar KKV-k 43,86\%-a nem adott számot logisztikai összköltségről, az egyes részköltségeknél azonban ennél lényegesen magasabb arányok adódtak. ${ }^{60}$ Ez megerősíti azokat a korábbi feltételezéseket és eredményeket, hogy a kis- és középvállalkozások a logisztikai költségeikkel egyáltalán nem vagy csak csekély mértékben vannak tisztában (Tempel és Meißner [2002]; Virum [1994]). A kereskedelemben, mezőgazdaságban és feldolgozóiparban állításuk alapján a KKV-k közel ötöde semmilyen logisztikai költséggel sem rendelkezett, a szolgáltatásokban pedig a vállalkozások több mint fele vélekedett ugyanígy. A feldolgozóiparban a korábbi kutatások (Berr et al. [1990]; Campos-Garcia et al. [2011]) által várt érték adódott.

${ }^{60}$ A logisztikai adminisztrációs költségről számot nem adó KKV-k aránya 58,98\%, a készlettartásiról $62,52 \%$, a szállításiról $63,32 \%$, a raktározásiról 74,05\%, a csomagolásiról $85,53 \%$, a készlethiányról pedig $90,22 \%$ volt. 
19. táblázat: A nulla logisztikai összköltségről számot adó magyar KKV-k aránya ágazat és vállalatméret szerint

\begin{tabular}{|l|c|c|c|c|c|}
\hline & 0 fös & $\begin{array}{c}\text { Mikro- } \\
\text { vállalkozás }\end{array}$ & $\begin{array}{c}\text { Kis- } \\
\text { vállalkozás }\end{array}$ & $\begin{array}{c}\text { Közép- } \\
\text { vállalkozás }\end{array}$ & Összesen \\
\hline Mezőgazdaság & $28,21 \%$ & $16,22 \%$ & $20,00 \%$ & $0,00 \%$ & $21,69 \%$ \\
\hline Feldolgozóipar & $34,62 \%$ & $17,24 \%$ & $10,00 \%$ & $0,00 \%$ & $22,06 \%$ \\
\hline Energiaszolgáltatás & $27,27 \%$ & $50,00 \%$ & - & $100,00 \%$ & $38,89 \%$ \\
\hline Építőipar & $54,55 \%$ & $28,38 \%$ & $20,00 \%$ & $100,00 \%$ & $43,08 \%$ \\
\hline Kereskedelem & $22,42 \%$ & $19,68 \%$ & $18,75 \%$ & $25,00 \%$ & $20,94 \%$ \\
\hline Szolgáltatás & $59,36 \%$ & $41,58 \%$ & $35,71 \%$ & $0,00 \%$ & $51,53 \%$ \\
\hline $\begin{array}{l}\text { Közösségi } \\
\text { szolgáltatás }\end{array}$ & $73,48 \%$ & $64,29 \%$ & $57,14 \%$ & $20,00 \%$ & $69,91 \%$ \\
\hline Összesen & $52,16 \%$ & $34,16 \%$ & $28,99 \%$ & $22,22 \%$ & $43,86 \%$ \\
\hline
\end{tabular}

Forrás: saját szerkesztés

Ágazati besorolás alapján a kereskedelem, a feldolgozóipar és a mezőgazdaság logisztikai összköltsége volt a legmagasabb, míg a közösségi szolgáltatásoké a legalacsonyabb.

21. ábra: Magyarországi KKV-k logisztikai költségszintjei ágazat szerint, 2009

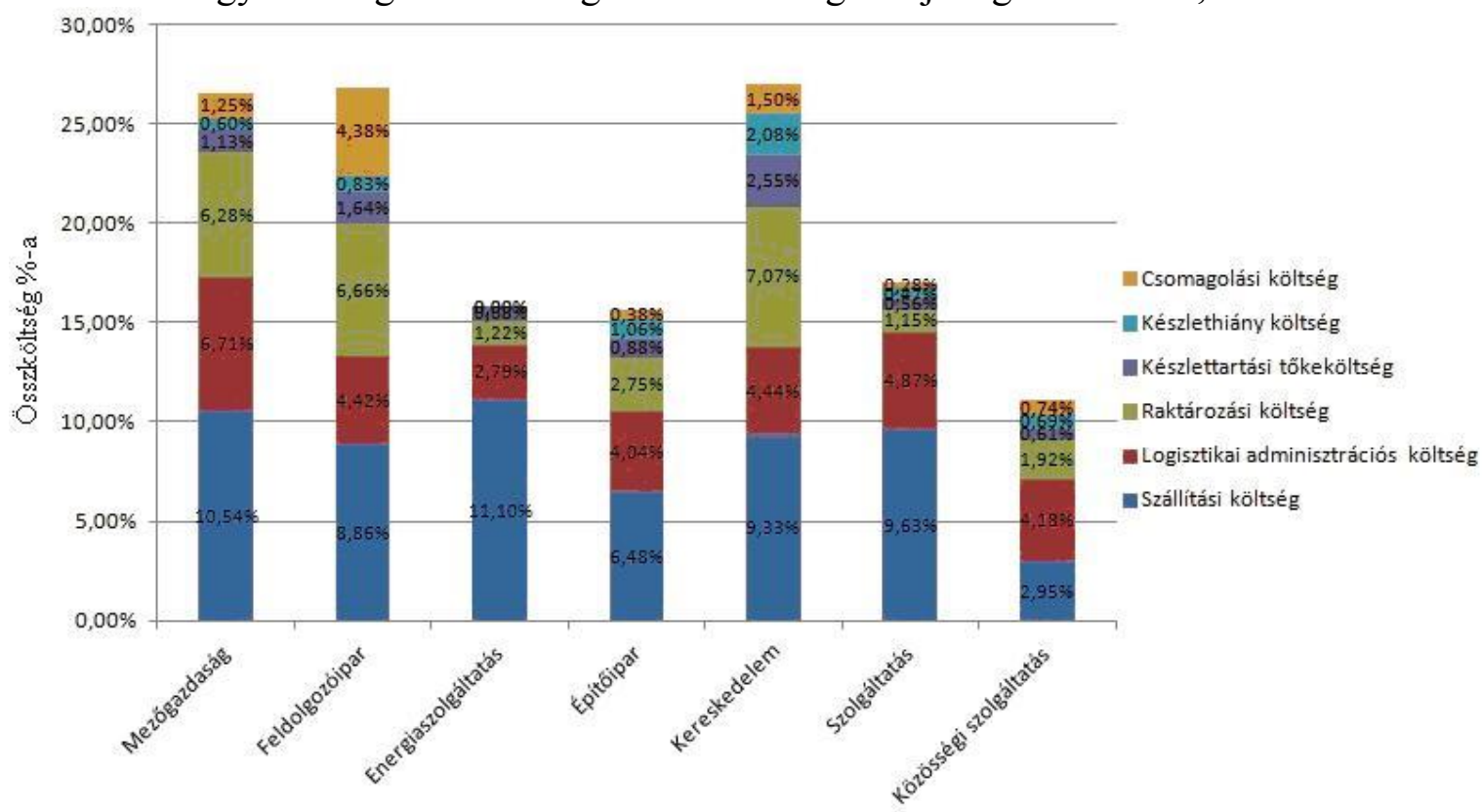

Forrás: saját szerkesztés

A hat logisztikai részköltség összefüggéseinek feltárására faktorelemzést végeztem. Ez a „Vállalkozások helyzetének felmérése 2009” mintanagysága (legalább 4-5-szörösen meghaladja a változókét és minimum 50-100) és egyéb tulajdonságai ${ }^{61}$ miatt

${ }^{61}$ Például tartalmi érvényesség, illetve az elemzés során a korrelációs és anti-image mátrix, valamint a Bartlett teszt is ezt erösíti meg. 
elvégezhető volt. Az elemzéshez a fökomponens elemezés módszerét használtam Varimax rotációs eljárással, melynek Kaiser-Meyer-Olkin (KMO) megfelelőségi mutatójának értéke 0,631 lett, ami mérsékeltnek (Ketskeméty et al. [2011] p. 239.) minősíthető. A faktorelemzés 2 faktort határozott meg, melyek a teljes variancia 43,64\%-át magyarázták. Ezek alapján a logisztikai részköltséget célszerübbnek $^{62}$ találtam a továbbiakban is külön-külön vizsgálni. Mindkét 3-3 költségelemet (raktározás, készlettartás, csomagolás, illetve szállítás, készlethiány, adminisztráció) tartalmazó faktor esetében a sajátérték egynél nagyobb volt.

A „Vállalkozások helyzetének felmérése 2009 ” teljes, azaz a 0 fös vállalkozásokat is tartalmazó metrikus skálán mért logisztikai összköltség- és részköltségszintjei:

- Nem normál eloszlásúak, amit vizuálisan a hisztogramok (lásd a 3. függelékben), illetve a Kolmogorov-Szmirnov próbák normalitási hipotéziseinek elvetése is jelzett, bár utóbbi a nagy mintákra (1000 elem felett) érzékeny (Sajtos és Mitev [2007] p. 118.).

- A varianciahomogenitás feltétele a szállítási és logisztikai adminisztrációs költség kivételével $^{63}$ a Levene tesztek alapján (lásd a 3. függelékben) nem teljesült.

A „Vállalkozások helyzetének felmérése 2009” logisztikai összköltség- és részköltségszinteknél a vállalatméret ${ }^{64}$ és az ágazat ${ }^{65}$ szerinti eltérések mellett az adatbázisban szereplő 11 egyéb változó alapján is kerestem a különbségeket. Ezek a területi elhelyezkedés ${ }^{66}$, a fö értékesítés helye ${ }^{67}$, a versenytárstól megkülönböztető elemek $^{68}$, a KKV első számú vezetőjének életkora ${ }^{69}$, iskolai végzettsége ${ }^{70}$, neme, a

\footnotetext{
${ }^{62}$ A társadalomtudományokban már 60\%-os varianciahányad is elfogadható. (Sajtos és Mitev [2007], p. 260.)

${ }^{63} \mathrm{~A}$ vállalatméret szerinti bontásban.

${ }^{64} 0$ fös, 1-9 fös, 10-49 fős vagy 50-249 fős. A „Vállalkozások helyzetének felmérése 2009” 30e. kérdése alapján besorolva.

65 Mezőgazdaság, feldolgozóipar, energiaszolgáltatás, építőipar, kereskedelem, szolgáltatás, vagy közösségi szolgáltatás. A „Vállalkozások helyzetének felmérése 2009” 5. kérdése alapján besorolva.

${ }^{66}$ Békés, Györ-Moson-Sopron, Hajdú-Bihar, Somogy megye, vagy Budapest. A „Vállalkozások helyzetének felmérése 2009" Megye kérdése alapján.

${ }^{67}$ Erre a településre; nem erre a településre, de megyén belül; megyén kívül, de Magyarországra; vagy külföldre. A „Vállalkozások helyzetének felmérése 2009” 7. kérdése alapján.

${ }^{68}$ Alacsonyabb ár, jobb minőség, nagyobb választék, korszerübb technológia, jobb kapcsolat a vevőkkel, rugalmasság, fizetési pontosság, szállítási határidők betartása, vagy egyéb. A „Vállalkozások helyzetének felmérése 2009" 26. kérdése alapján.

${ }_{69} 25$ év alatt, 25-35 éves, 36-45 éves, 46-55 éves, vagy 55 évesnél idősebb. A „Vállalkozások helyzetének felmérése 2009" 28. kérdése alapján.
} 
KKV kora ${ }^{71}$, az, hogy együttmüködésben részt vesz-e, társas vagy egyéni vállalkozás, a vállalkozás helyzete $^{72}$ és a településtípus ${ }^{73}$, ahol a vállalkozás müködik. Minden esetben Levene tesztekkel vizsgáltam a variancia-homogenitást. Ha teljesült, akkor varianciaelemzéssel (ANOVA), ha nem és a változónak (pl. versenytárstól megkülönböztető elemek) legalább három szempontja volt, akkor Kruskal-Wallis ${ }^{74}$ próbákkal végeztem el az eltérések vizsgálatát. A Kruskal-Wallis próbák homogenitásra vonatkozó nullhipotézise elvetésekor a páronkénti, illetve bináris/dichotóm változóknál (pl. KKV vezető neménél férfi vagy nő) heteroszkedaszticitás esetén a további vizsgálatokat Mann-Whitney próbákkal végeztem el.

A logisztikai összköltség és valamennyi részköltség a Kruskal-Wallis tesztek és egyszempontos szóráselemzések alapján 5\%-os szignifikanciaszinten a vállalatméret és az ágazat alapján nem homogén. Ez azt jelenti, hogy volt legalább egy-egy részszempont, amelyek között szignifikáns eltérés áll fenn. A többi változót vizsgálva a vállalkozás helyzete alapján 1, a területi elhelyezkedésnél, a településtípusnál, az első számú vezető iskolai végzettségénél és a versenytárstól megkülönböztető elemeknél 22-2-2, a fö értékesítési hely alapján 3, az első számú vezető és a KKV kora esetében pedig 5-5 költségelem esetében homogén. Utóbbi azt jelenti, hogy az így létrehozott csoportok között nem volt szignifikáns a különbség. (pl. a raktározási költség tekintetében, hogy az első számú vezető 25 év alatti, 25-35 éves, 36-45 éves, 46-55 éves vagy éppen 55 évesnél idősebb.) Az eredményeknél tekintettel kell lenni arra, hogy a „Vállalkozások helyzetének felmérése 2009” részmintáinak magas elemszáma önmagában is szignifikáns eltérésekhez vezethetett.

\footnotetext{
70 Főiskola, egyetem; gimnáziumi, szakközépiskolai érettségi; 8 általános + szakmunkásképző; 8 általános; vagy kevesebb, mint 8 általános. A „Vállalkozások helyzetének felmérése 2009” 29. kérdése alapján.

711995 előtt, 1995 és 2000 között, 2001 és 2005 között vagy 2006-ban és az után alapították. „Vállalkozások helyzetének felmérése 2009”3. kérdése alapján besorolva.

72 Jó, közepes vagy rossz. A „Vállalkozások helyzetének felmérése 2009” 51. kérdése alapján.

${ }^{73}$ Főváros, megyeszékhely, város vagy község. A „Vállalkozások helyzetének felmérése 2009” Település neve kérdése alapján besorolva.

74 A részminták függetlennek tekinthetők, a szórások közelítőleg azonosak, ezért nem a JonckheereTerpstra próbát alkalmaztam.
} 
20. táblázat: Logisztikai összköltség és részköltségek adott szempont szerinti eltéréseinek szignifikancia-szintjei ${ }^{75}$

\begin{tabular}{|c|c|c|c|c|c|c|c|}
\hline & 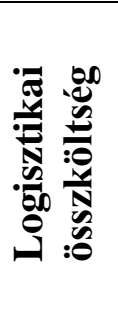 & 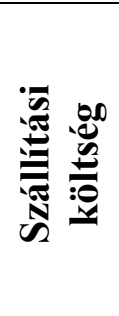 & 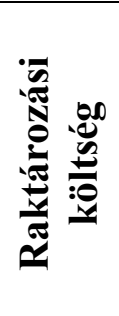 & 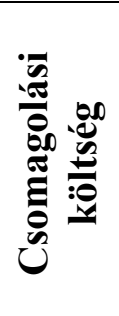 & 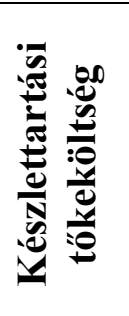 & 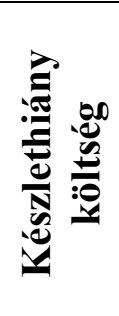 & 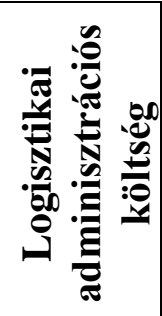 \\
\hline Vállalatméret &, 000 &, $002 *$ & ,000 &, 000 &, 000 &, 000 & ,000 \\
\hline Ágazat &, 000 &, 000 &, 000 &, 000 &, 000 &, 000 &, 000 \\
\hline Területi elhelyezkedés &, 001 &, 000 & ,142 & ,764 & ,008 &, 002 &, 000 \\
\hline Fö értékesítés helye &, 000 &, 000 & ,334* & ,267 & ,027 &, 524 & ,000 \\
\hline $\begin{array}{l}\text { Versenytárstól } \\
\text { megkülönböztető } \\
\text { elemek }\end{array}$ &, 000 &, 000 & ,000 &, 001 &, $045^{*}$ & ,907* &, $894 *$ \\
\hline $\begin{array}{l}\text { Az első számú vezetö } \\
\text { életkora }\end{array}$ & ,354 & ,038 &, $614^{*}$ & ,338 &, $785^{*}$ &, $764^{*}$ & ,008 \\
\hline $\begin{array}{l}\text { Az első számú vezető } \\
\text { iskolai végzettsége }\end{array}$ &, $011 *$ &, 000 & ,000 & ,002 &, 000 & ,232 & ,069 \\
\hline KKV kora & ,201* & ,289* & ,206* & ,007 &, 000 & ,411 &, $570 *$ \\
\hline KKV jelenlegi helyzete &, 000 &, 035 &, 025 & ,114* &, 000 &, 000 &, 000 \\
\hline Településtípus &, 000 &, 000 & ,048 & ,964* & ,256 & ,011 &, 000 \\
\hline
\end{tabular}

*: ANOVA F próba, egyéb esetben a Kruskal-Wallis próbák szignifikanciaszintjei

Forrás: saját szerkesztés

A páronkénti ANOVA és Mann-Whitney tesztek eredményeiböl csak a szélsőértékeket emelem ki, melyre kevés általános kijelentés tehető. Szignifikáns eltérést találtam:

- ágazati bontásban, ahol minden más ágazat hasonló költségeinél alacsonyabb volt a közösségi szolgáltatási szektor szállítási költsége, magasabb a feldolgozóipar csomagolási költsége, alacsonyabb a szolgáltató szektor készlettartási tőkeköltsége a kereskedelemé pedig magasabb.

- területi elhelyezkedés szerinti csoportosításban Békés megye és az összes többi vizsgált megye között a szállítási költségnél, Somogy megye esetében a logisztikai adminisztrációs költségnél.

- fó értékesités helye szerint abban, hogy erre a településre és a megyén belül értékesít, melyek szállítási költsége és logisztikai összköltsége a két legalacsonyabb volt. Ez részben megerősítette a „Finland State of Logistics” 2008-as, ám

\footnotetext{
75 A 0,05 (5\%-os szingnifikancia-szint) alatti értékek azt jelentik, hogy a homogenitásra vonatkozó nullhipotézist el kell vetni.
} 
ellentmondott a 2005-ös eredményének (Solakivi et al. [2009]), ahogyan a norvég kutatókénak (Lea et al. [1996]) is.

- abban, hogy a nagyobb választék „stratégia” minden más versenytárstól megkülönböztető elemnél magasabb raktározási költségekkel járt.

- a hogyan itéli meg a vállalkozás helyzetét kérdés esetében a ,javul” a legalacsonyabb, a „nem változik” közepes és a „romlik” legmagasabb logisztikai adminisztrációs és összköltséget jelentette. A romló helyzetű KKV-k minden másnál magasabb raktározási, készlettartási és készlethiány költségekkel szembesültek.

- a településtípus alapján abban, hogy a községekben müködő KKV-k szállítási költsége és logisztikai összköltsége minden más településtípusnál (város, megyeszékhely, főváros) magasabb volt. A megyeszékhelyen müködő kis- és középvállalkozások készlethiány költsége minden másnál magasabb volt.

A dichotóm változók tekintetében:

- A férfiak vezette ${ }^{76} \mathrm{KKV}-\mathrm{k}$ logisztikai részköltségei és összköltségei alacsonyabbak voltak, mint a nők vezette kis- és középvállalkozásoké, mely csak a csomagolási, készlettartási és logisztikai adminisztrációs költség esetén nem volt szignifikáns.

- $\mathrm{Az}$ együttműködésben való részvétel ${ }^{77}$ általában magasabb költségekkel ${ }^{78}$ járt. $\mathrm{Az}$ eltérés csak a készlethiány és a logisztikai adminisztrációs költségnél volt szignifikáns.

- A társas vállalkozások ${ }^{79}$ valamennyi logisztikai részköltsége és összköltsége magasabb volt, mint az egyénieké, igaz ez nem volt szignifikáns a szállítási, a készlethiány és a logisztikai adminisztrációs költség esetében.

Sajnos a magyarországi KKV-k átlagos logisztikai költségszintjei nem voltak összehasonlíthatók a külföldi tanulmányokéval az eltérő módszertan miatt és abból kifolyólag, hogy azok általában csak a költségszintek átlagait tették közzé. A feldolgozóipari, kereskedelmi és szolgáltató vállalkozások logisztikai költségszintátlagai (lásd a 3. függelékben) magasabbak voltak a korábbi KKV-s logisztikai kutatásokban szereplő értékeknél (Bagchi és Virum [2000]; Szabó [2005]; Vízhányó

\footnotetext{
${ }^{76}$ A „Vállalkozások helyzetének felmérése 2009” 27. kérdése alapján.

${ }^{77}$ A „Vállalkozások helyzetének felmérése 2009” 23. kérdése alapján.

${ }^{78}$ Kivéve raktározási és csomagolási költségeket, ahol alacsonyabb volt.

${ }^{79}$ A ,Vállalkozások helyzetének felmérése 2009” 4. kérdése alapján.
} 
[2006]; Ojala et al. [2007]; Hovi és Hansen [2010]; Solakivi et al. [2010]; CamposGarcia et al. [2011]) és ez fokozottan érvényes volt a nagyvállalatiakra (ELA és A.T. Kearney [2009]). A magyarországi feldolgozóipari KKV-k logisztikai összköltségszintje a mexikói adatokhoz (Campos-Garcia et al. [2011]) állt a legközelebb, igaz a megfelelő adatok hiányában ennek, ahogyan az előzőek szignifikáns voltáról sem tudunk semmit mondani.

\subsubsection{Logisztikai tevékenységkiszervezési arányok}

A „Vállalkozások helyzetének felmérése 2009” 17. kérdése keretében a logisztikai tevékenységkiszervezésnél a KKV-k listából választhattak, hogy a szállítástrakománykezelést, a raktározást-tárolást, a csomagolást, a szállítmányozást, a rendeléskezelést, a készletmenedzsmentet és az ehhez szükséges informatikai rendszereket külső szolgáltatók nyújtják-e ${ }^{80}$. A 22. ábrán látható eredmények alapján a legnagyobb arányú outsourcing a szállítási és rakománykezelési tevékenységnél volt, melyet a vállalkozások 15,03\%-a helyezett ki. Ezt a szállítmányozás 6,69\%-kal, a logisztikai informatika 4,68\%-kal, a raktározás-tárolás 4,00\%-kal, a rendeléskezelés 3,07\%-kal, a csomagolás 1,80\%-kal és a készletmenedzsment 0,15\%-kal követte. A magyarországi KKV-k 2009-ben döntően az egyszerübb logisztikai résztevékenységeket helyezték ki, a szállítmányozás kiszervezésének magas aránya pedig Murphy et al. [1995], valamint Pearson és Semeijn [1999] eredményeit tükrözte vissza.

22. ábra: Logisztikai tevékenységkiszervező KKV-k aránya vállalatméret alapján, 2009

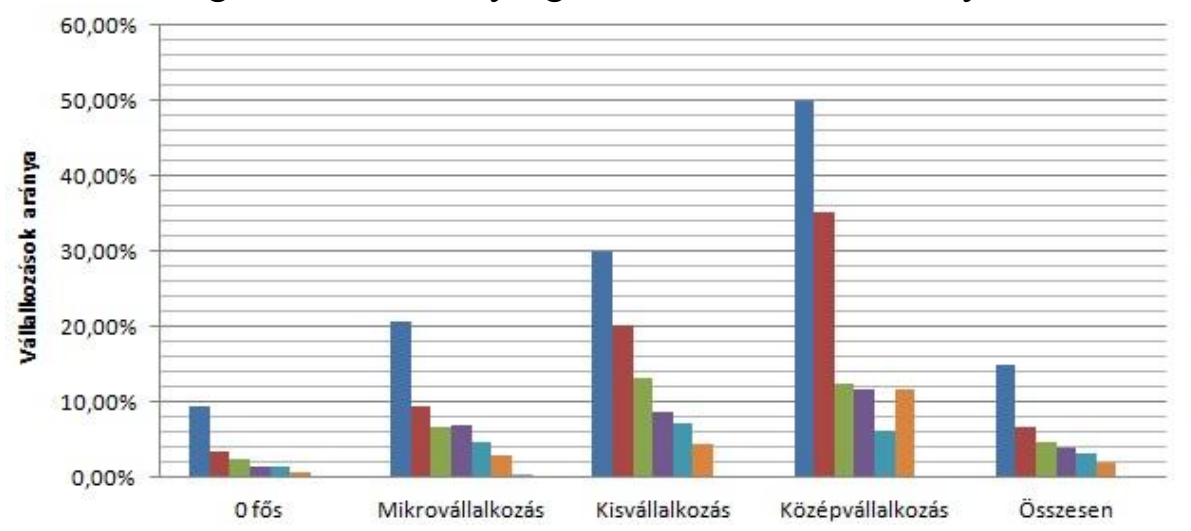

Ezállitás-rakománykezelés - Szállítmányozás - Logisztikai informatika Eaktározás-tárolás nendeléskezelés Esomagolás Készletmenedzsment

Forrás: saját szerkesztés

\footnotetext{
${ }^{80}$ Lehetséges válaszkategóriák: nem végzik, max. 5\%-át, 5\%-nál több, de max. 25\%-át, 25\%-nál több, de max. 50\%-át, 50\%-nál több, de max. 75\%-át, több mint 75\%-át. Megjegyzem, hogy a kiszervezést általában százalékos formában mérik (pl. „Lieb sorozatok”, „Langley sorozatok”), bár kivételek (pl. Armstrong jelentések) előfordulnak. (Ashenbaum et al. [2005])
} 
A mintában szereplő logisztikai outsourcingot végző magyarországi KKV-k közel fele egyszerre több résztevékenységet is kiszervezett. Ezek közül a leggyakrabban a szállítás-szállítmányozás (29,35\%), a szállítás-raktározás (7,07\%), a szállításraktározás-szállítmányozás $(7,07 \%)$ és a szállítmányozás-logisztikai informatika (4,35\%) fordult elő. (a többit lásd a 3. függelékben)

Valamennyi logisztikai résztevékenységet figyelembe véve a legnagyobb kiszervezési aránnyal a mezőgazdaság, a feldolgozóipar és a kereskedelem, a legalacsonyabbal pedig a szolgáltatás és a közösségi szolgáltatás rendelkezett.

23. ábra: Logisztikai tevékenységeiket kiszervező KKV-k aránya ágazatonként, 2009

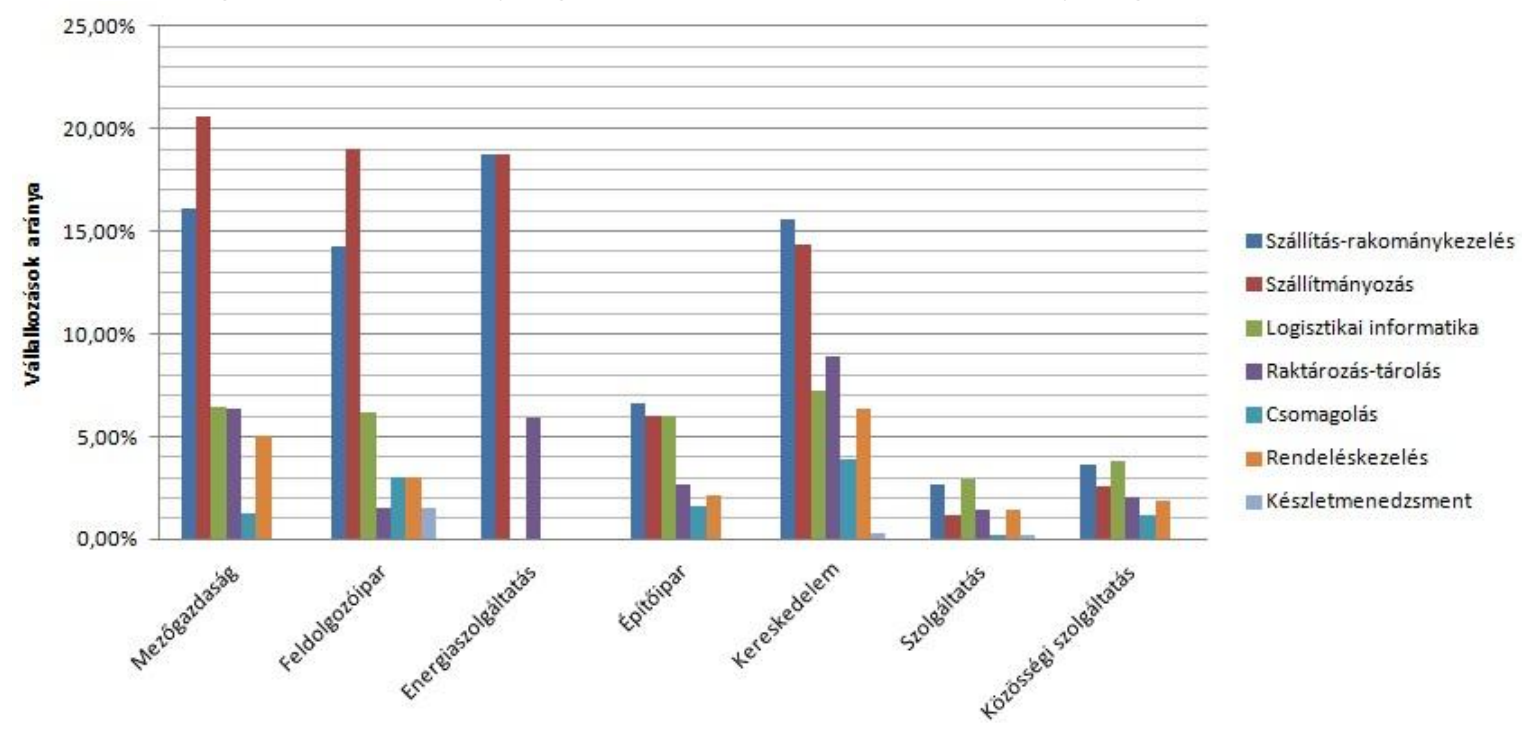

Forrás: saját szerkesztés

A „Versenyben a világgal 2009” adatfelvétel K52 kérdésénél is vizsgálták a szállítmányozás-fuvarozást, a raktározást és a készletgazdálkodást, de csak igen-nem kérdésekkel. Itt a „Vállalkozások helyzetének felmérése 2009” mintájában szereplőnél magasabb outsourcing arányok születtek, melyek a 21. táblázatban láthatóak. A jelentős eltérés oka vélhetően a feldolgozóipar, illetve a nagyobb méretű vállalkozások magasabb mintabeli arányával magyarázható. 
21. táblázat: Logisztikai résztevékenységek kiszervezése a „Versenyben a világgal 2009” adatbázis alapján

\begin{tabular}{|l|c|c|c|c|}
\hline & Mikrovállalkozás & Kisvállalkozás & Középvállalkozás & $\begin{array}{c}\text { Összes } \\
\text { KKV }\end{array}$ \\
\hline $\begin{array}{l}\text { Szállítmányozás, } \\
\text { fuvarozás }\end{array}$ & $57,14 \%$ & $70,73 \%$ & $73,79 \%$ & $70,91 \%$ \\
\hline Raktározás & $33,33 \%$ & $31,71 \%$ & $20,59 \%$ & $25,00 \%$ \\
\hline Készletgazdálkodás & $28,57 \%$ & $24,39 \%$ & $16,67 \%$ & $20,12 \%$ \\
\hline
\end{tabular}

Forrás: saját szerkesztés

A „Vállalkozások helyzetének felmérése 2009” adatbázisban szereplő kiszervezhető logisztikai résztevékenységek összefüggéseinek feltárására a részköltségekhez hasonlóan főkomponens elemzést végeztem Varimax rotációs eljárással. A KaiserMeyer-Olkin megfelelőségi mutató értéke 0,751 volt, ami közepesnek minősíthető. (Ketskeméty et al. [2011] p. 239.) A faktorelemzés 2 faktort határozott meg, melyek a teljes variancia 57,85\%-át magyarázzák. (Mindkét faktor esetében a sajátérték egynél nagyobb volt.) A rotált komponens mátrix alapján a szállítás és szállítmányozás került egy faktorba, a többi résztevékenység pedig egy másikba. Előbbi megerősíti 300 magyarországi logisztikai vállalkozás körében végzett felmérést, mely kimutatta, hogy a logisztikai szolgáltatások közül leggyakrabban a szállítás és a szállítmányozás kapcsolódik össze. (Bank et al. [2010] p. 65.)

22. táblázat: Logisztikai tevékenységkiszervezési arányok rotált komponens mátrixa

\begin{tabular}{|l|c|c|}
\hline & 1 komponens & 2 komponens \\
\hline $\begin{array}{l}\text { Szállítás és rakománykezelés kiszervezés } \\
\text { aránya }\end{array}$ &, 129 &, 846 \\
\hline Raktározás, tárolás kiszervezési aránya &, 579 &, 323 \\
\hline Csomagoláskiszervezés aránya &, 858 &, 102 \\
\hline Szállítmányozás kiszervezési aránya &, 202 &, 788 \\
\hline Készletmenedzsment kiszervezési aránya &, 830 &, 011 \\
\hline Rendeléskezelés kiszervezési aránya &, 607 &, 223 \\
\hline Logisztikai informatika kiszervezési aránya &, 553 &, 235 \\
\hline
\end{tabular}

Forrás: saját szerkesztés

A faktorelemzés eredményének függvényében a továbbiakban is külön-külön vizsgáltam a logisztikai résztevékenységek kiszervezését. A készletmenedzsmentet a továbbiakban nem elemeztem, mivel kiszervezése csak néhány esetben fordult elö, ezért torzíthatta volna az eredményeket. 
Az egyes logisztikai tevékenységek kihelyezései(re $)^{81}$ :

- nem voltak normál eloszlásúak, amit vizuálisan a hisztogramok (lásd a 3. függelékben), illetve a Kolmogorov-Szmirnov próbák normalitási hipotéziseinek elvetése is jelzett.

- a varianciahomogenitás feltétele ${ }^{82}$ a Levene tesztek (lásd a 3. függelékben) alapján nem teljesült.

A logisztikai résztevékenységek outsourcingjánál felmerülő különbségeket a logisztikai költségekhez hasonló módszerrel vizsgáltam. (ANOVA, vagy Kruskal-Wallis és/vagy Mann-Whitney próbák). A vállalatméret, az ágazat, a fó értékesítés helye és a versenytárstól megkülönböztető elemek valamennyi logisztikai résztevékenység kihelyezése esetén heterogénnek bizonyultak, a területi elhelyezkedésnél és az első számú vezető iskolai végzettségénél 1-1, a KKV-k jelenlegi helyzeténél és a településtípusnál 2-2, az első számú vezető koránál 4 kiszervezési elem esetében volt homogén. Valamennyi logisztikai tevékenységkiszervezési elem a KKV kora alapján homogénnek bizonyult.

23. táblázat: Logisztikai tevékenységkiszervezések adott szempont szerinti eltéréseinek szignifikancia-szintjei

\begin{tabular}{|c|c|c|c|c|c|c|}
\hline & 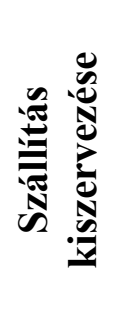 & 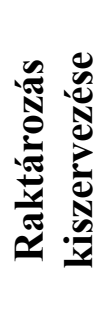 & 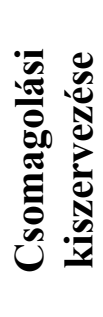 & 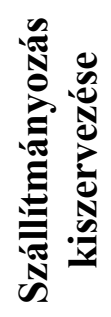 & 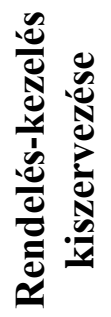 & 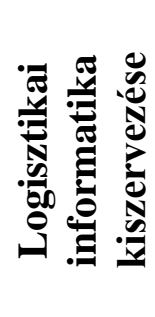 \\
\hline Vállalatméret & ,000 & 000 &, 000 & , 000 & , 000 & ,000 \\
\hline Ágazat & ,000 & ,000 & ,000 &, 000 & ,000 & 018 \\
\hline Területi elhelyezkedés & ,000 & ,000 & ,000 & ,922* & ,000 & ,000 \\
\hline Fő értékesítés helye &, 000 &, 000 &, 001 & 000 &, 000 &, 000 \\
\hline Versenytárstól megkülönböztető elemek &, 000 &, 000 &, 009 &, 009 & ,008 & ,008 \\
\hline Az első számú vezető életkora & 177 & ,022 & ,035 & 104 & 479 & ,746* \\
\hline Az első számú vezető iskolai végzettsége &, 027 & 238 &, 012 & ,005 & 013 &, 000 \\
\hline KKV kora & ,126 & ,717 & ,199 & ,735 & ,900 & 219 \\
\hline KKV jelenlegi helyzete & ,630* &, 000 & ,006 & ,430 & ,005 &, 030 \\
\hline Településtípus & ,640* &, 000 &, 000 &, 305 &, 000 &, 000 \\
\hline
\end{tabular}

*: ANOVA F próba, egyéb esetben a Kruskal-Wallis próbák szignifikanciaszintjei

Forrás: saját szerkesztés

\footnotetext{
${ }^{81}$ A készletmenedzsmentre például a varianciahomogenitás fennáll.

${ }^{82}$ A vállalatméret szerinti bontásban.
} 
A páronkénti ANOVA és Mann-Whitney tesztek eredményei alapján itt is csak a szélsőértékeket emeltem ki, mellyel kapcsolatban itt is csak kevés általános kijelentést lehetett tenni. Szignifikáns eltérést találtam:

- ágazati bontásban, ahol a szolgáltatás és közösségi szolgáltatás alacsony szintü szállítmányozás outsourcing arányaival minden más ágazattól különbözött.

- területi elhelyezkedés szerinti csoportosításban a budapesti KKV-k rendeléskezelési, raktározási és csomagolási outsourcing arányánál, ami valamennyi vidéki KKV-énál magasabb, a somogyi kis- és középvállalkozások szállításkiszervezésénél, ami pedig minden más KKV-énál alacsonyabb szintü volt.

- a településtipus szerinti bontásban abban, hogy a fóvárosi KKV-k raktározási, csomagolási, rendeléskezelési és logisztikai informatikai kiszervezési aránya a vidéki kis- és középvállalkozásokénál magasabb volt.

A bináris változók tekintetében:

- A férfiak vezette KKV-k logisztikai tevékenységkiszervezési arányai magasabbak voltak, mint a női vezetésü kis- és középvállalkozásoké, mely csak a szállítás. raktározás és szállítmányozás esetén volt szignifikáns.

- Az együttmüködésben való részvétel alacsonyabb kiszervezési aránnyal járt. Az eltérés csak a szállítási, szállítmányozási és logisztikai informatika outsourcingnál volt szignifikáns.

- A társas vállalkozások logisztikai tevékenységkiszervezési aránya magasabb lett az egyénieknél, mely minden esetben szignifikáns volt.

Sajnos a magyarországi KKV-k logisztikai tevékenységkiszervezési arányai a költségszinteknél már említett okok miatt nem voltak összehasonlíthatóak a hazai (Vízhányó [2006]; Teleki et al. [2009]) és a külföldi tanulmányokéval (pl. „Lieb sorozatok” és „Langley sorozatok” ${ }^{\text {} 33}$ sorozatok). Az általam használt két adatbázis eredményei ellentmondásos eredményekre vezettek: a „Versenyben a világgal 2009” alapján a korábbi kutatások alapján a várt, a „Vállalkozások helyzetének felmérése

83 A tanulmány szerint Európában 2009-ben a szállítás 91-92\%-át, a raktározás 72\%-át, a szállítmányozás 57\%-át, a logisztikai informatika 34\%-át szervezték ki. (Langley és Capgemini, 2009, 12. o.) 
2009” alapján pedig annál alacsonyabb értékek adódtak, igaz ezek szignifikáns voltáról semmit sem mondhatunk.

\subsubsection{Logisztikai költségszintek vs. tevékenységkiszervezési arányok}

A logisztikai költségek és outsourcing egymásra gyakorolt hatását Pearson-féle korrelációs együtthatókkal vizsgáltam. A logisztikai összköltséget valamennyi résztevékenység kiszervezésével összehasonlítottam, a részköltségeknél azonban csak párosítottan elemeztem az azonos résztevékenységre vonatkozókat (pl. szállítási költség vs. szállítás kiszervezése).

24. táblázat: Egyes logisztikai költségszintek és kiszervezési arányok Pearson-féle korrelációi

\begin{tabular}{|l|c|c|c|c|}
\hline & $\begin{array}{c}\text { Logisztikai } \\
\text { összköltség }\end{array}$ & $\begin{array}{c}\text { Szállítási } \\
\text { költség }\end{array}$ & $\begin{array}{c}\text { Raktározási } \\
\text { költség }\end{array}$ & $\begin{array}{c}\text { Csomagolási } \\
\text { költség }\end{array}$ \\
\hline Szállítás kiszervezése &, 328 &, 281 & - & - \\
\hline Raktározás kiszervezése &, 184 & - &, 247 & - \\
\hline Csomagolás kiszervezése &, 155 & - & - &, 252 \\
\hline Szállítmányozás kiszervezése &, 192 & - & - & - \\
\hline Rendeléskezelés kiszervezése &, 159 & - & - & - \\
\hline $\begin{array}{l}\text { Logisztikai informatika } \\
\text { kiszervezése }\end{array}$ &, 122 & - & - & - \\
\hline
\end{tabular}

Forrás: saját szerkesztés

A valamennyi esetben szignifikáns volt a korreláció. A változók között a szállítás kiszervezése és a szállítás költség, illetve a logisztikai összköltség, valamint a raktározás kiszervezése és a raktározási összköltség, a csomagolás kiszervezése és a csomagolási költség között közepes, a többi esetben pedig gyenge pozitív kapcsolat volt. A vizsgálatot a mezőgazdaságra, feldolgozóiparra és kereskedelemre leszükítve is elvégeztem, ahol hasonló, bár többnyire alacsonyabb korrelációs értékek adódtak. (lásd a 3. függeléket) 


\subsection{H1 hipotézisek vizsgálata}

A H1 hipotézisek szerint a vállalatméret és az ágazat a logisztikai költségszintek és tevékenységkiszervezési arányok két legfontosabb kontingencia-tényezője, melynek vizsgálatához a „Vállalkozások helyzetének felmérése 2009” 3-5., 7., 13., 17., 23., 2630., 51. kérdéseit használtam fel. Ezek a változók nominális vagy ordinális mérési skálájúak. A felmérésben szereplő változók vizsgálathoz a normalitás és a varianciahomogenitás megsértése miatt nem használtam a szóráselemzést, annak ellenére sem, hogy az F próba robosztus. Helyette skála-transzformációkat hajtottam végre és az egyik leggyakrabban használt többváltozós módszert, a kereszttábla-elemzést választottam. A logisztikai részköltségszinteket és tevékenységkiszervezési arányokat 3-3 kategóriába transzformáltam le/át: 0\% (ide sorolva a nem tudja válaszokat is), 0$50 \%$ és $50 \%$ feletti. Ezzel csökkent annak az esélye, hogy a kereszttáblák celláinak várható értékei 5 alattiak legyenek, amire a Khi-négyzet próba érzékeny ${ }^{84}$. Az asszociációs mértékek között nincs „legjobb”, de azonos mutatót használva a szorosabb kapcsolat kimutatható. (Füstös et al. [2004] p. 80.) A nominális vagy ordinális skálás független és intervallum skálás függő változó közötti vegyes kapcsolatot az éta ${ }^{85}$ mutatóval vizsgáltam, melynek eredményei a 25. táblázatban láthatóak. Az éta választását az indokolta, hogy az egyetlen olyan SPSS által előállított mutató, mely független kategóriaváltozó és intervallum szintű függő változó kapcsolatát méri.

\footnotetext{
${ }^{84}$ A kritérium szigorúbb változata szerint a kereszttábla nem tekinthető megbízhatónak, ha ez bármelyik cellájára igaz, a kevésbé szigorú szerint ez a cellák max. 20\%-ra lehet ilyen. (Sajtos és Mitev [2007] p. 154.)

${ }^{85}$ Értéke 0 és 1 közötti, előbbi a függetlenséget, utóbbi a determinisztikus kapcsolatot jelenti.
} 
25. táblázat: Logisztikai költségekre és tevékenységkiszervezésre ható tényezők éta értékei

\begin{tabular}{|c|c|c|c|c|c|c|c|c|c|c|c|c|c|}
\hline & 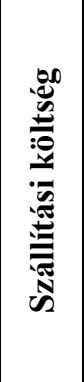 & 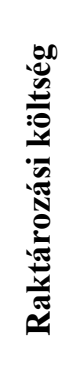 & 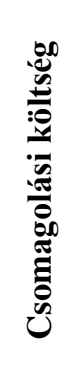 & 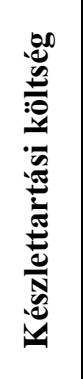 & 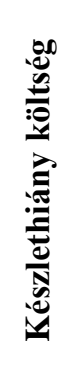 & 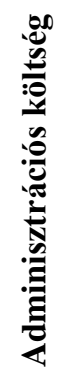 & 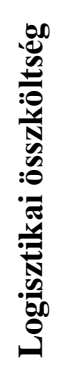 & 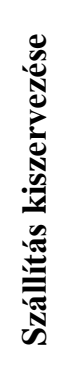 & 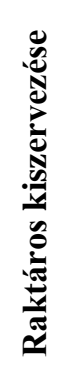 & 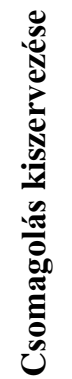 & 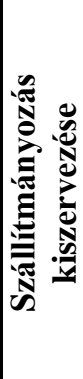 & 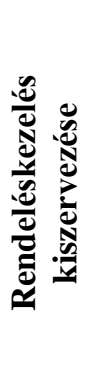 & 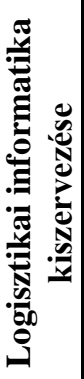 \\
\hline Vállalatméret & ,229 & ,267 & ,197 & ,207 & ,106 & ,214 & ,186 & ,191 & ,153 & ,092 &, 180 & ,119 & ,125 \\
\hline Ágazat & ,291 & 193 & ,120 & ,176 & ,053 & ,209 & ,257 & ,182 & ,060 & $*$ & ,166 & , 045 & ,062 \\
\hline $\begin{array}{l}\text { Területi } \\
\text { elhelyezkedés }\end{array}$ & ,084 & $*$ & $*$ & $*$ &, 051 &, 031 & ,023 & ,063 & ,064 & ,047 & $*$ &, 064 &, 051 \\
\hline $\begin{array}{l}\text { Fó értékesítés } \\
\text { helye }\end{array}$ & ,193 & $*$ & $*$ & $*$ & $*$ & ,088 &, 150 & , 127 & ,145 &, 052 &, 118 &, 067 &, 113 \\
\hline $\begin{array}{l}\text { Versenytárstól } \\
\text { megkülönböztető } \\
\text { elemek }\end{array}$ & , 106 & ,027 & ,022 & ,000 & $*$ & ,037 & ,079 & ,063 & ,022 & $*$ &, 092 & ,059 & ,056 \\
\hline $\begin{array}{l}\text { Az első számú } \\
\text { vezető életkora }\end{array}$ & $*$ & $*$ & $*$ & $*$ & * & ,087 & $*$ & $*$ & $*$ & $*$ & $*$ & $*$ & ,030 \\
\hline $\begin{array}{l}\text { Az első számú } \\
\text { vezető iskolai } \\
\text { végzettsége } \\
\end{array}$ & , 109 & ,056 & ,000 & ,097 & $*$ & ,073 &, 142 & ,067 & $*$ & $*$ & $*$ & $*$ & ,086 \\
\hline KKV kora & ,039 &, 051 & ,028 & ,064 & $*$ & ,053 & ,059 & $*$ & $*$ & $*$ & $*$ & $*$ & $*$ \\
\hline Településtípus & ,099 & ,032 & $*$ & $*$ & $*$ & ,082 & , 143 & $*$ & ,112 & ,093 & $*$ & ,122 & $*$ \\
\hline $\begin{array}{l}\text { KKV jelenlegi } \\
\text { helyzete }\end{array}$ & $*$ & $*$ & $*$ & ,029 & $*$ & ,045 & ,062 & $*$ &, 100 & $*$ & $*$ &, 070 & $*$ \\
\hline $\begin{array}{l}\text { Társas vagy egyéni } \\
\text { vállalkozás }\end{array}$ &, 149 &, 145 &, 108 & ,112 & ,076 &, 140 & ,119 & , 131 & ,084 & 075, & , 109 & 096, & ,121 \\
\hline $\begin{array}{l}\text { Az első számú } \\
\text { vezető férfi vagy } \\
\text { nő }\end{array}$ & , 162 & 099, & $*$ & 051 & $*$ & 107, & 099, & ,118 & 063 & $*$ & ,086 & $*$ & $*$ \\
\hline $\begin{array}{l}\text { Együittmúkiödésben } \\
\text { részt vesz-e }\end{array}$ & ,063 & $*$ & $*$ & $*$ & $*$ & 094 & 094 & 103, & $*$ & $*$ & 146 & $*$ & 105 \\
\hline
\end{tabular}

*Khi-négyzet alapján független, ezért az éta nem kerül feltüntetésre

Forrás: saját szerkesztés

A „Vállalkozások helyzetének felmérése 2009” teljes mintáját használva az éták alapján megerősítést nyert, hogy a vállalatméret és az ágazat a két legfontosabb kontingenciatényező. Ez alól a készlethiány költség szintje, a raktározás, a csomagolás, a rendeléskezelés és a logisztikai informatikai kiszervezési aránya volt kivétel. A készlethiány költséget és a logisztikai informatika kiszervezést leginkább a vállalkozás mérete mellett annak társas vagy egyéni volta befolyásolta, a csomagolás és rendeléskezelés outsourcingját pedig a település típusa. A raktározás kiszervezését a fó értékesítés helye a vállalakozás méretével együtt magyarázta a legerősebben. Ezek alapján a 13 részhipotézis öt esetben nem igazolódott, tehát a logisztikai összköltség és 
részköltségszintek, illetve a tevékenységkiszervezés szempontjából a vállalatméret ténylegesen a legfontosabb kontingencia-tényező, az ágazat azonban csak egy részüknél.

Megjegyzem, hogy az éták alapján ezek a vegyes kapcsolatok gyenge-közepesnek minősültek, melyek tovább csökkentek, ha a vizsgálatot a legnagyobb logisztikai összköltségszintü és tevékenységkiszervezési arányú ágazatokra, azaz a mezőgazdaságra, feldolgozóiparra és kereskedelemre szükítettem le (lásd a 3. függeléket). Utóbbi esetben az ágazat szerepe - az adatbázis csak két TEÁOR kód mélységü besorolást tartalmaz - szinte teljesen visszaszorult, és az együttmüködés magyarázó szerepe a fô értékesítés helyével és településtípussal együtt megerősödött. Emellett jelentősen megnőtt a magyarázó és magyarázott változó közötti függetlenség előfordulása.

\subsection{H2 hipotézis vizsgálata}

A H2 hipotézis a magyarországi KKV-k szállítási és raktározási igényéből adódó jelentős látens keresletbővülésre vonatkozott. A vizsgálatnál a „Vállalkozások helyzetének felmérése 2009" minta reprezentativitását kiaknázva határoztam meg a magyarországi KKV-k szállítási és raktározási keresletét, felhasználva:

- A társasági adóbevallást készítő KKV-k 2009. évi összes költség és ráfordítás ${ }^{86}$ adatát (Nemzeti Adó- és Vámhivatal [2011]).

- A társas vállalkozások szállítási és raktározási költség és kiszervezés értékeit. Az egyéni vállalkozókét azért nem használtam, mivel nem készítenek társasági adóbevallást. A szállítás és raktározás az egyes kategóriákba eső arányok és a sávközepek szorzatainak összegével (értékarány) határoztam meg, feltételezve, hogy a válaszokban megadott kiszervezés szintje és értéke egymással arányos.

A keresletet és az outsourcingot az alábbi saját készítésü képletekkel határoztam meg.

$$
\begin{aligned}
& D_{S M E t r}=T C_{S M E} * c_{t r} \\
& D_{S M E w}=T C_{S M E} * c_{w}
\end{aligned}
$$

\footnotetext{
${ }^{86}$ Csak az anyagjellegủ ráfordításokat (pl. anyagköltség, eladott, közvetített szolgáltatások értéke, eladott áruk beszerzési értéke, egyéb szolgáltatások értéke, igénybevett szolgáltatások értéke, bankköltség, biztosítási díj), személyi jellegü ráfordításokat (pl. bérköltség, személyi jellegü kifizetések), értékcsökkenést és egyéb ráfordításokat (pl. adójellegü ráfordítások) tartalmazza.
} 
$\mathrm{v}_{\mathrm{tr}}=\frac{1}{n} \sum_{i=1}^{l}$ tr.out $_{i}$

$\mathrm{v}_{\mathrm{w}}=\frac{1}{n} \sum_{j=1}^{m} w_{\text {out }}$

Ahol,

- $\mathrm{D}_{\mathrm{SMEtr}}, \mathrm{D}_{\mathrm{SMEw}}$ : a társas KKV-k szállítási és rakománykezelési, illetve raktározási és tárolási kereslete;

- $\quad$ TC $_{\mathrm{SME}}$ : a társas KKV-k összköltsége a mintavétel évében, ami 2009-ben 28855,719 milliárd Ft-ot ért el. ${ }^{87}$ (Nemzeti Adó- és Vámhivatal [2011])

- $\quad \mathrm{c}_{\mathrm{tr}}, \mathrm{c}_{\mathrm{w}}$ : a mintában szereplő KKV-k szállítási és rakománykezelési, illetve raktározási és tárolási költségeinek számtani átlaga $\left(\mathrm{c}_{\mathrm{tr}}=0,0725 ; \mathrm{c}_{\mathrm{w}}=0,0376\right)$, melyet a „Vállalkozások helyzetének felmérése 2009” adatbázis 13a-b) kérdései alapján határoztam meg;

- $\mathrm{V}_{\mathrm{tr}}, \mathrm{v}_{\mathrm{w}}$ : a szállítás és rakománykezelés, illetve a raktározás és tárolás kiszervezés értékaránya;

- 1, m: a szállítást és rakománykezelést, a raktározást és tárolást kiszervező KKV-k száma a mintában;

- n: a mintában szereplő vállalkozások száma;

- tr.out $\mathrm{i}_{1}, \mathrm{w} . \mathrm{out}_{\mathrm{j}}$ : az i. társas KKV esetében a szállítás és rakománykezelés, illetve raktározás és tárolás hány százalékát végzik külső szolgáltatók. (nem végzik esetén 0,0 , max. $5 \%$ esetén 0,025 , max. $25 \%$ esetén 0,15 , max. $50 \%$ esetén 0,375 , max. $75 \%$ esetén 0,625 , több mint 75\% esetén 0,875). Ezt a „Vállalkozások helyzetének felmérése 2009" adatbázis 17a-b) kérdései alapján határoztam meg

A fentiek alapján a magyarországi KKV-k 2009-es:

- szállítás-rakománykezelés kereslete ( $\mathrm{D}_{\mathrm{SMEtr}}$ ), azaz az általuk generált maximális piacméret 2092,040 milliárd Ft-ot ért el, melynek 6,75\%-a $\left(\mathrm{v}_{\mathrm{tr}}\right)$ kiszervezett volt, azaz 141,213 milliárd Ft-ot külső szolgáltatok végeztek. A fennmaradó 1950,827 milliárd Ft-nyi keresletet viszont saját maguk látták el, mely a magyar fuvarozó és

87 2009-ben a KKV-k összes nettó árbevétele 27624,072 milliárd Ft-ot (Nemzeti Adó- és Vámhivatal, [2011]), a folyó áras GDP pedig a Központi Statisztikai Hivatal szerint 26747,7 milliárd Ft-ot ért el. Ez bizonyos mértékben konvertálhatóvá teszi a költségarányosan mért logisztikai költségszinteket. Az 5.1.1. fejezetben ismertetett amúgy sem alacsony költségszintek árbevétel-arányosan átlagosan 4,46\%-kal, GDP arányosan pedig 7,88\%-kal lennének magasabbak. 


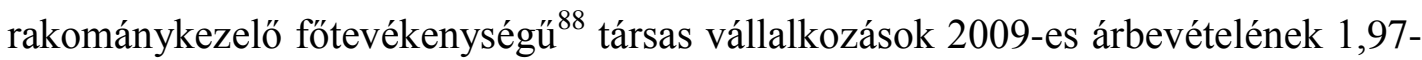
szeresét jelentette, azaz ekkora lett volna a látens fuvarozási keresletbővülés.

- raktározási-tárolási kereslete $\left(\mathrm{D}_{\mathrm{SMEw}}\right)$, azaz így 1084,975 milliárd Ft-os piacméret jöhetett volna létre. Ennek 0,8\%-át $\left(\mathrm{v}_{\mathrm{w}}\right)$, azaz 8,680 milliárd Ft-nyit kiszerveztek; a fennmaradó 1076,295 milliárd Ft-nyi keresletet viszont saját maguk végezték. Ez utóbbi a magyar raktározási és tárolási fötevékenységü ${ }^{89}$ társas vállalkozások 2009es árbevételének 3,53-szeresét jelentette, azaz a látens raktározási piacbővülés ekkora lett volna.

E potenciál kiaknázása a szolgáltatóknak nem könnyü, mivel a KKV-k viszonylag nagy arányban tekintik a logisztikát alapvető képességnek (lásd később a H3a hipotézisnél). Emellett a „Vállalkozások helyzetének felmérése 2009” 17. számú, azaz az elkövetkezendő 5 évben a szállítás- és a raktározás kiszervezésének változását célzó kérdésre adott válaszok alapján valamennyi vállalkozási méretkategóriában a válaszadók legalább 2/3-a változatlanságra számított. Ez a nem tudja válaszokkal együtt 91\% feletti „status quo” arányt jelent. Megjegyzem, hogy a „Versenyben a világgal 2009” kutatásban hasonló eredmények adódtak: a felmért KKV-k 88,48\%-a az elkövetkezendő három évben a fuvarozás-szállítmányozás, 92,07\%-a pedig a raktározás kiszervezését nem tervezte, igaz ott a „Vállalkozások helyzetének felmérése 2009”-hez képest magasabb voltak az indulási kiszervezési arányok.

\footnotetext{
${ }^{88}$ TEÁOR’08 49.20 vasúti áruszállítás, 49.41 közúti áruszállítás, 49.42 költöztetés, 49.50 csővezetékes szállítás, 50.20 tengeri áruszállítás, 50.40 belvízi áruszállítás, 51.21. légi áruszállítás és 52.24. rakománykezelés. Az ilyen főtevékenységü társas vállalkozások 2009-es nettó árbevétele a Nemzeti Adóés Vámhivatal adatközlése alapján 991,645 milliárd Ft-ot ért el.

89 TEÁOR'08 52.10. raktározás, tárolás. Az ilyen főtevékenységű társas vállalkozások 2009-es nettó árbevétele a Nemzeti Adó- és Vámhivatal adatközlése alapján 304,745 milliárd Ft-ot ért el.
} 
24. ábra: Társas KKV szállítás és raktározás kiszervezésének változása a 2009-öt követő 5 évben

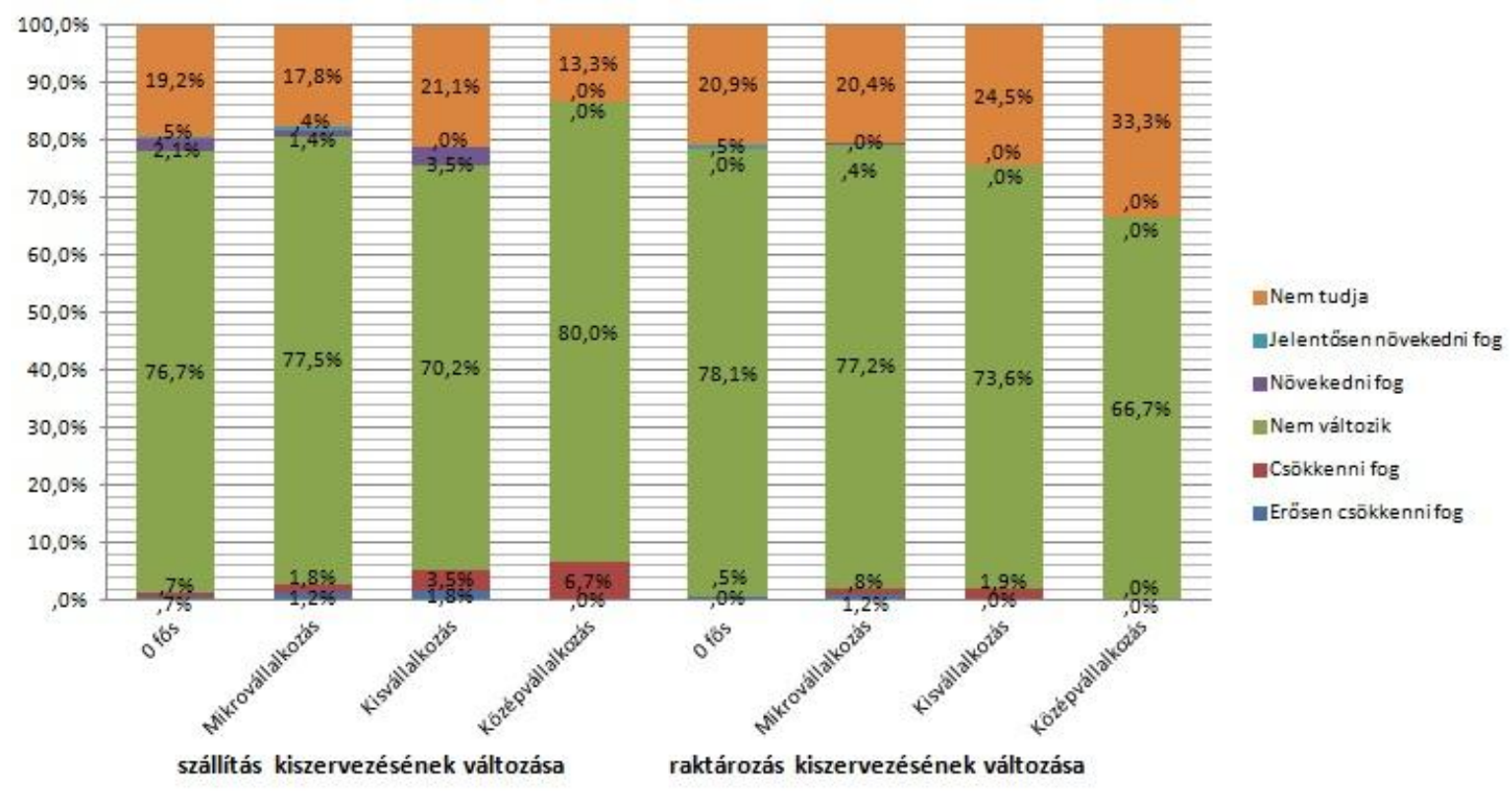

Forrás: saját szerkesztés

Az előzőhöz hasonló módszerrel a magyarországi társas KKV-k logisztikai összköltsége is meghatározható volt. A hazai társas kis- és középvállalkozások logisztikai összköltsége 2009-ben 6143,734 milliárd Ft volt, mely a vállalati összköltség arányában 21,94\%-ot, árbevétel-arányosan 22,24\%-ot, GDP-arányosan pedig 22,97\%-ot ért el. Ez a korábbi kutatásokkal (pl. King [2010] ${ }^{90}$; Solakivi et al. $[2010]^{91}$ ) összehasonlítva igen magasnak tekinthető, különösen úgy, hogy ez sem a nagyvállalatok, sem pedig az egyéni vállalkozások logisztikai költségeit nem tartalmazta. A logisztikai összköltségek ilyen magas mértéke esetleg a finnekhez hasonló célkitűzésre ösztönözheti a kormányzatot, ugyanis a logisztikai összköltség már 3,4\%-os csökkentése is a vállalkozások adminisztratív terheinek mérsékléséhez hasonló megtakarítást ${ }^{92}$ tenne lehetővé. Kummer [1995] szerint e racionalizálás hatása limitált és ezzel elveszhetnek a fogyasztói érték növelésének lehetőségei.

\footnotetext{
90 2009-ben a dél-afrikai logisztikai költségeket a GDP 14,7\%-ra becsülte.

91 2009-ben a finn logisztikai költségeket a GDP 8,7\%-ára becsülte.

92 A Deloitte [2010] tanulmánya szerint a vállalkozások adminisztratív terheinek csökkentésével 208 milliárd Ft megtakarítást lehetne elérni.
} 


\subsection{H3 hipotézisek vizsgálata}

A „Vállalkozások helyzetének felmérése 2009” alapján a H3 hipotéziseimmel a magyarországi KKV logisztikai tevékenységkiszervezési döntését vizsgáltam:

- A H3a hipotézis arra vonatkozott, hogy a különböző méretü KKV-k a logisztikát alapvető képességnek tekintik-e és e tevékenység kiszervezésnél milyen tranzakciós költségekkel szembesülnek.

- A H3b hipotézis a logisztikai tevékenységkiszervezés fó okaként a költségcsökkentést, az alapvető képességekre koncentrálást és a rugalmasságot feltételezte.

- A H3c hipotézis McIvor modelljének a magyarországi KKV-k logisztikai tevékenységkiszervezésre adaptálhatóságát feltételezte.

A „Vállalkozások helyzetének felmérése 2009” 18. és 19. kérdései keretében a KKV-k a szállítás, raktározás és csomagolás kiszervezésének okaira igen, nem vagy nem tudja válaszokat adhattak. A válaszok ellentmondásosak voltak, melyet a tevékenységkiszervezés költségekre gyakorolt hatására adott válaszok kereszttáblája és annak 0,599-es Cramer $\mathrm{V}^{93}$ értéke is jelezett.

26. táblázat: Logisztikai tevékenységek költségcsökkentésére adott válaszok

\begin{tabular}{|c|c|c|c|c|}
\hline \multicolumn{2}{|c|}{} & \multicolumn{3}{|c|}{$\begin{array}{c}\text { Az e tevékenységekhez kapcsolódó } \\
\text { költségeket a kihelyezés nem csökkenti }\end{array}$} \\
\cline { 3 - 5 } & Igen & Nem & Nem tudja \\
\hline \multirow{2}{*}{$\begin{array}{c}\text { Ezen } \\
\text { tevékenységekhez } \\
\text { kapcsolódó költségek } \\
\text { csökkennek }\end{array}$} & Nem & 62 & 119 & 3 \\
\cline { 2 - 5 } & $\begin{array}{c}\text { Nem } \\
\text { tudja }\end{array}$ & 15 & 965 & 62 \\
\hline
\end{tabular}

Forrás: saját szerkesztés

Hasonló eredményre vezetettek, 0,611-es Cramer V értékkel, a szolgáltatás minőségjavulására vs. romlására vonatkozó kérdésekre adott válaszok. Emiatt az ilyen ellenőrző kérdéseknél a direkt módon feltett kérdésre adott választ tekintettem irányadónak. Az outsourcing érvek páronként igen erősen összefüggtek, közülük a legerősebben a szolgáltatótól való függőség és a szolgáltatási színvonal ellenőrzésének nehézsége. A mezőgazdaságra, feldolgozóiparra és kereskedelemre leszükített vizsgálatok hasonló eredményre vezettek. (lásd a 3. függelékben)

\footnotetext{
${ }^{93}$ A kapcsolat nagyon erős ugyan, de a Cramer V maximális értéke 1 lehet.
} 
27. táblázat: Kiszervezés érveinek páronkénti asszociációját mutató Cramer V mértékek

\begin{tabular}{|c|c|c|c|c|c|c|c|c|c|c|c|c|c|c|c|c|}
\hline & $\stackrel{0}{-}$ & $\ddot{\mathscr{\Omega}}$ & $\infty$ & $\cong$ & $\stackrel{\infty}{=}$ & $\stackrel{\infty}{\infty}$ & 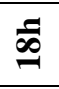 & อ็ & $\hat{\sigma}$ & $\check{2}$ & 2 & 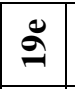 & $\ddot{\sigma}$ & 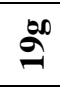 & $\underline{\sigma}$ & $\ddot{z}$ \\
\hline 18a: Földrajzi terjeszkedés & $\stackrel{\nabla}{\nabla}$ & ః. & $\hat{\imath}$ & बे. & 络 & $\stackrel{5}{8}$ & s. & 胥 & : & $\overbrace{0}^{\infty}$ & के & రి & $\begin{array}{l}n \\
\infty \\
n \\
n\end{array}$ & 8 & $\frac{m}{6}$ & $\overline{8}$ \\
\hline 18b: Minőség-javulás & ' & $\stackrel{n}{n}$ & 8 & 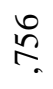 & $\stackrel{2}{?}$ & กै & શิ & $\frac{0}{6}$ & s. & है & $\underset{i}{i}$ & $\overline{0}$ & in & oे & ర్ర & $\stackrel{\infty}{0}$ \\
\hline 18c: Költség-csökkenés & & 1 & $\underset{⿱}{\stackrel{7}{*}}$ & ปู & बे. & बे. & $\frac{m}{\pi}$ & : & $\overbrace{0}^{2}$ & के & $\underset{n}{n}$ & $\stackrel{\infty}{0}_{0}^{\infty}$ & के & $\stackrel{\infty}{0}$ & $\underset{ర}{\mathbb{U}}$ & $\overbrace{0}^{2}$ \\
\hline 18d: Rugalmas kapacitás & & & ' & $\underset{r}{\stackrel{F}{*}}$ & $\stackrel{\text { O }}{\rightarrow}$ & $\frac{\partial}{\nabla}$ & $\frac{1}{\pi}$ & $\overrightarrow{\mathrm{b}}$ & $\bar{\sigma}$ & $\frac{0}{6}$ & $\stackrel{\infty}{\infty}$ & $\frac{1}{6}$ & ते & స్ & $\hat{\sigma}_{0}^{\infty}$ & $\stackrel{\infty}{6}$ \\
\hline $\begin{array}{l}\text { 18e: Külső szakértelem } \\
\text { igénye }\end{array}$ & & & & & \&ి. & กิ & $\stackrel{2}{i}$ & $\bar{\sigma}$ & $\bar{\sigma}$ & $\frac{0}{6}$ & $\begin{array}{l}\infty \\
\infty \\
\text { ? }\end{array}$ & : & ฉิ & $\bar{b}$ & ర్రి & $\stackrel{\infty}{0}$ \\
\hline $\begin{array}{l}\text { 18f: Alapvető } \\
\text { képességfókusz }\end{array}$ & & & & & ' & ఫ̊. & के. & $\frac{n}{6}$ & $\frac{0}{6}$ & $\underset{\sigma}{0}$ & $\begin{array}{l}\infty \\
\infty \\
\text { n. }\end{array}$ & రి. & ते & đ్ర & $\tilde{\sigma}$ & $\frac{1}{b}$ \\
\hline 18g: Vásárló elvárja & & & & & & ' & $\stackrel{\infty}{\sim}$ & : & $\frac{0}{6}$ & oे & $\stackrel{\infty}{\infty}$ & $\frac{7}{6}$ & ס. & 8 & $\frac{0}{6}$ & है \\
\hline 18h: Beszállító elvárja & & & & & & & ' & $\frac{m}{6}$ & $\frac{0}{6}$ & $\frac{m}{6}$ & $\begin{array}{l}\infty \\
i n\end{array}$ & $\frac{n}{6}$ & ? & : & $\frac{\infty}{6}$ & $\stackrel{\circ}{6}$ \\
\hline 19a: Ellenőrzés elvesztése & & & & & & & & ' & $\underset{⿱}{\stackrel{N}{*}}$ & $\bar{\infty}$. & $\stackrel{m}{\Re}$ & $\stackrel{\infty}{\stackrel{\infty}{ } .}$ & $\begin{array}{l}0 \\
0 \\
0\end{array}$ & $\stackrel{+}{2}$ & $\underset{\infty}{\mathbb{\infty}}$ & $\underset{\infty}{\mathbb{S}}$ \\
\hline $\begin{array}{l}\text { 19b: A száll., rakt., csom. } \\
\text { alapvető képesség }\end{array}$ & & & & & & & & & & $\stackrel{n}{\infty}$ & f. & $\stackrel{\infty}{\stackrel{\infty}{ } .}$ & 8 & $\stackrel{0}{\stackrel{1}{r}}$ & $\stackrel{2}{R}$ & $\stackrel{\infty}{\stackrel{n}{r}}$ \\
\hline 19c: Költség nem csökken & & & & & & & & & & & $\widehat{\stackrel{N}{N}}$ & $\stackrel{\infty}{\infty}$ & $\stackrel{\infty}{0}$ & $\stackrel{\infty}{\stackrel{\infty}{r}}$ & $\bar{r}$ & 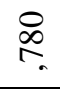 \\
\hline 19d: Jobb a szakértelmünk & & & & & & & & & & & ' & 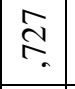 & $\stackrel{\infty}{0}$ & $\stackrel{ }{F}$ & $\stackrel{P}{ }$ & $\underset{f}{\stackrel{T}{t}}$ \\
\hline 19e: Minőség-csökkenés & & & & & & & & & & & & ' & హ̆ & $\stackrel{0}{\stackrel{2}{~}}$ & $\bar{r}$ & $\stackrel{尺}{尺}$ \\
\hline $\begin{array}{l}\text { 19f: Nem tudja, miként } \\
\text { vegye igénybe }\end{array}$ & & & & & & & & & & & & & ' & $\vec{\infty}$ & 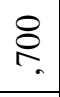 & $\stackrel{\rho}{\circ}$ \\
\hline 19g: Rejtett költségek & & & & & & & & & & & & & & ' & $\begin{array}{c}\widehat{\infty} \\
\infty\end{array}$ & స్ \\
\hline 19h: Függőség nő & & & & & & & & & & & & & & & & $\underset{\infty}{\infty}$ \\
\hline $\begin{array}{l}\text { 19i: Értékelés és ellenőrzés } \\
\text { nehézsége }\end{array}$ & & & & & & & & & & & & & & & & \\
\hline
\end{tabular}

Forrás: saját szerkesztés

A „Vállalkozások helyzetének felmérése 2009” 17. kérdésében külön-külön szereplő szállítás-, raktározás- és csomagolás kihelyezést igen-nem kategóriákba vontam össze úgy, hogy a háromból bármelyik résztevékenység kihelyezés esetén igen kategóriába soroltam. Az összegzéssel létrehozott skála megbízhatóságát a Cronbach-féle alfával vizsgáltam. Ennek értéke 0,778 lett, ami alapján a belső konzisztencián alapuló megbízhatóság elfogadható.

A vizsgálatot leszükítettem a mezőgazdaságra, feldolgozóiparra és kereskedelemre, mivel ezen ágazatokban volt a legmagasabb a szállítási, raktározási és csomagolási 
tevékenységek kiszervezési aránya. E lépéssel a mintanagyság is csökkent, amire a Khinégyzet statisztika érzékeny.

A H3a hipotézis gyakorlatilag két részből állt: az alapvető képességek, illetve a növekvő tranzakciós költségek vizsgálatából.

- Az alapvető képességekbe sorolás megbízhatóságát ${ }^{94}$ jelezte, hogy a 70 szállítás, raktározás, posta, távközlés főtevékenységü vállalkozásból csak 34 tartotta annak a szállítást, raktározást és csomagolást. A feldolgozóipari KKV-k 42,65\%-a, a mezőgazdaságiak 33,33\%-a, a kereskedők 24,67\%, tartotta a szállítást, raktározást és csomagolást alapvető képességének. A 28. táblázatban látható, hogy a mikrovállalkozások 28,5\%-a, a kisvállalkozások 41,9\%-a, a középvállalkozások 33,3\%-a tartotta alapvető képességnek a szállítást, raktározást és csomagolást, ám a két változó a Pearson-féle Khi-négyzet statisztika szerint csak 5,7\%-os szignifikancia szint felett függött egymástól. A standardizált korrigált reziduumok egy kivétellel -2 és +2 közötti értékei alapján a kereszttáblán belüli szignifikáns összefüggésekről semmi bizonyosat nem mondhatunk. A hipotézis tehát nem igazolódott. Megjegyzem, hogy valamennyi ágazatra - vélhetően a nagyobb mintaméret hatása miatt - már 5\%-on is szignifikáns volt az összefüggés a két változó között, ám ott a középvállalkozások oszlopszázalékai (35,3\%) meghaladták mind a kis- $(32,9 \%)$, mind pedig a mikrovállalkozásokét $(24,4 \%)$.

28. táblázat: A szállítást, raktározást és csomagolást alapvető képességüknek tekintő magyarországi mezőgazdasági, feldolgozóipari és kereskedelemi KKV-k

\begin{tabular}{|c|c|c|c|c|c|}
\hline & \multicolumn{3}{|c|}{$\begin{array}{c}\text { A szállítás, raktározás és csomagolás } \\
\text { alapvető képesség }\end{array}$} \\
\hline & & & Igen & Nem & Nem tudja \\
\hline \multirow{8}{*}{ 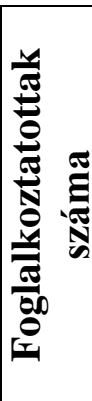 } & \multirow{2}{*}{0 fö } & Száma (\%) & $84(24,4 \%)$ & $200(58,1 \%)$ & $60(17,4 \%)$ \\
\hline & & Korr. reziduumok & $-1,6$ &,- 5 & 2,8 \\
\hline & \multirow{2}{*}{$\begin{array}{l}1-9 \\
\text { fó }\end{array}$} & Száma (\%) & $108(28,5 \%)$ & $229(60,4 \%)$ & $42(11,1 \%)$ \\
\hline & & Korr. reziduumok &, 8 &, 7 & $-2,0$ \\
\hline & \multirow{2}{*}{$\begin{array}{c}10- \\
49 \text { fó }\end{array}$} & Száma (\%) & $13(41,9 \%)$ & $16(51,6 \%)$ & $2(6,5 \%)$ \\
\hline & & Korr. reziduumok & 1,9 &,- 9 & $-1,2$ \\
\hline & \multirow{2}{*}{$\begin{array}{l}50 \text { fö } \\
\text { felett }\end{array}$} & Száma (\%) & $3(33,3 \%)$ & $6(66,7 \%)$ & $0(0,0 \%)$ \\
\hline & & Korr. reziduumok &, 4 &, 5 & $-1,2$ \\
\hline & & Összesen (\%) & $208(27,3 \%)$ & $451(59,1 \%)$ & $104(13,6 \%)$ \\
\hline
\end{tabular}

Forrás: saját szerkesztés

${ }^{94}$ A kérdőív korlátai miatt csak igen-nem kérdés keretében lehetett vizsgálni, mely távol áll a Beumer et al. [2009] által javasolt négyfázisú operacionalizálástól, mely azt vizsgálja, hogy a képesség értékes-e, ritka-e, nehezen másolható-e és tartós-e. 
- A növekvő tranzakciós költséget a „Vállalkozások helyzetének felmérése 2009” 18c és $19 \mathrm{~g}$ változóinak (költség növekedés és a rejtett költség együttes fennállása) összevonásával határoztam meg, melynek Cronbach-féle alfa értéke 0,800 lett. Az így összevont változót az előzőhöz hasonló módon vizsgálva azt kaptam, hogy a függőség már 5\%-os szignifikanciaszinten is igaz a mezőgazdasági, feldolgozóipari és kereskedelmi vállalkozások körében, ám ebben a mikro-, kis és középvállalkozások szinte alig különböztek. (mikrovállalkozásoknál: 29,1\%, kisvállalkozásoknál 29,0\%, közepeseknél 33,3\% az arányuk). Valamennyi szektort vizsgálva a mikro és kisvállalkozások esetében az előfordulás aránya közel hasonló volt (26,0\% és 23,9\%), a középvállalkozásoknál azonban lényegesen magasabb érték adódott. $(41,2 \%)$

29. táblázat: A magyarországi mezőgazdasági, feldolgozóipari és kereskedelemi KKV-k tranzakciós költségeinek változása

\begin{tabular}{|c|c|c|c|c|c|c|}
\hline & \multicolumn{4}{|c|}{ Tranzakciós költség változása } \\
\hline & & & Csökkenő & Növekvő & Nincs & Nem tudja \\
\hline \multirow{8}{*}{ 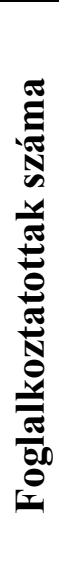 } & \multirow[b]{2}{*}{$\stackrel{i e}{0}$} & Száma (\%) & $20(5,8 \%)$ & $69(19,9 \%)$ & $185(53,5 \%)$ & $72(20,8 \%)$ \\
\hline & & $\begin{array}{r}\text { Korr. } \\
\text { reziduumok }\end{array}$ & $-1,2$ & $-3,0$ & 1,2 & 2,7 \\
\hline & \multirow{2}{*}{$\stackrel{i}{9}$} & Száma (\%) & $28(7,3 \%)$ & $111(29,1 \%)$ & $188(49,3 \%)$ & $54(14,2 \%)$ \\
\hline & & $\begin{array}{r}\text { Korr. } \\
\text { reziduumok }\end{array}$ &, 3 & 2,6 & $-1,0$ & $-1,9$ \\
\hline & \multirow{2}{*}{ 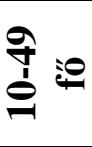 } & Száma (\%) & $5(16,1 \%)$ & $9(29,0 \%)$ & $15(48,4 \%)$ & $2(6,5 \%)$ \\
\hline & & $\begin{array}{r}\text { Korr. } \\
\text { reziduumok }\end{array}$ & 2,0 &, 5 &,- 3 & $-1,6$ \\
\hline & \multirow{2}{*}{ 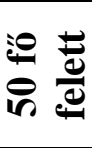 } & Száma (\%) & $1(11,1 \%)$ & $3(33,3 \%)$ & $4(44,4 \%)$ & $1(11,1 \%)$ \\
\hline & & $\begin{array}{r}\text { Korr. } \\
\text { reziduumok }\end{array}$ &, 5 & 6 &,- 4 &,- 5 \\
\hline & & Összesen (\%) & $54(7,0 \%)$ & $192(25,0 \%)$ & $392(51,1 \%)$ & 129 \\
\hline
\end{tabular}

Forrás: saját szerkesztés

A H3a hipotézisem tehát csak részben igazolódott és a vizsgálat nem tekinthető megbízhatónak, mivel a cellák legfeljebb 20\%-ának lehetett volna 5 alatti várható értéke (Sajtos és Mitev [2007] p. 154.), mely egyik esetben sem teljesült. Úgy tünik, hogy a mezőgazdasági, feldolgozóipari és kereskedelmi mkv-k méretük növekedésével egyre nagyobb mértékben tartották alapvető képességnek a szállítást, a raktározást és a csomagolást, ám a középvállalkozások esetében ez megváltozott. Vélhetően ehhez a nagyobb specializáció és a fötevékenységre történő erősebb koncentrálás vezetett. A logisztikai tevékenységek kiszervezésének tranzakciós költségek tekintetében pedig 
vélhetően a középvállalkozások sem voltak elég nagyok a méretgazdaságosság eléréshez.

A H3b hipotézis vizsgálatakor a „Vállalkozások helyzetének felmérése 2009” szállításiraktározási-csomagolási kiszervezését független, az okokat függő változónak választottam, majd fordítva is vizsgáltam az összefüggést. Ezt azért tettem, mert a válaszok alapján nem volt egyértelmü, hogy a KKV-k az elönyök és hátrányok alapján döntöttek az outsourcingról vagy a saját tevékenységvégzésről, esetleg a kiszervezett tevékenység tapasztalatai alapján gondolták át azokat (pl. ráébrednek a hátrányokra). A kiszervezés melletti és elleni érvek és a kiszervezés megléte, illetve hiánya között a függőség a Pearson-féle Khi-négyzet alapján valamennyi esetben szignifikáns volt. Az asszociációs mértékek között nincs „legjobb”, de azonos mutatót használva a szorosabb kapcsolat kimutatható. (Füstös et al. [2004] p. 80.). A H3 hipotéziseknél elsősorban azért a Cramer V-t használtam, mivel logisztikai tevékenységkiszervezés melletti és elleni érvek nominális változók, a létrejövő $3 * 3$-as kereszttáblák szimmetrikusak és a még lehetséges kontingencia-együttható értéke ritkán éri el az 1-et. (Sajtos és Mitev [2007] p. 151.) A H3b hipotézis vizsgálatához használt Cramer V értékek a következőképpen alakultak:

30. táblázat: Logisztikai tevékenységkiszervezés és annak okai közötti kapcsolat erössége a mezőgazdasági, feldolgozóipari és kereskedelmi KKV-k körében

\begin{tabular}{|l|c|l|c|}
\hline \multicolumn{1}{|c|}{$\begin{array}{c}\text { Kiszervezés melletti } \\
\text { érvek }\end{array}$} & $\begin{array}{c}\text { Cramer } \\
\text { V értéke }\end{array}$ & \multicolumn{1}{|c|}{ Kiszervezés elleni érvek } & $\begin{array}{c}\text { Cramer V } \\
\text { értéke }\end{array}$ \\
\hline Földrajzi terjeszkedés &, 255 & Ellenőrzés elvesztése &, 176 \\
\hline Minőségjavulás &, 326 & $\begin{array}{l}\text { A szállítás, raktározás, } \\
\text { csomagolás alapvető képesség }\end{array}$ &, 190 \\
\hline Költségcsökkenés &, 391 & Költségnövekedés &, 177 \\
\hline Rugalmas kapacitás &, 395 & Jobb szakértelem &, 171 \\
\hline Külső szakértelem igénye &, 262 & $\begin{array}{l}\text { Nem tudja, miként vegye } \\
\text { igénybe }\end{array}$ &, 174 \\
\hline Alapvető képességfókusz &, 317 & Minőségcsökkenés &, 171 \\
\hline Vásárló elvárja &, 241 & Rejtett költségek &, 192 \\
\hline Beszállító elvárja &, 273 & Függőség nő &, 204 \\
\hline & & $\begin{array}{l}\text { Értékelés és ellenőrzés } \\
\text { nehézsége }\end{array}$ &, 173 \\
\cline { 4 - 4 } & &
\end{tabular}

Forrás: saját szerkesztés

A növekvő függőség kivételével a logisztikai kiszervezés elleni érvek és az outsourcing szintje között gyenge, míg a mellette szóló érvek szerint közepes erősségü kapcsolat 
volt. A legerősebb magyarázatot a rugalmas kapacitás és a költségcsökkentés jelentette, melyet a minőségjavulás, illetve az alapvető képességfókusz követett. A H3b hipotézisem részben tehát megerősítést nyert, de a várthoz képest a logisztikai tevékenységkiszervezés magyarázatai között fontos új szempontként jelent meg a minőség javítása. A négy fö tényező önmagában is csak kis mértékben magyarázta a kiszervezést: a Goodman és Kruksal-féle tau alapján 3,3-6,6\%-ban, a bizonytalansági együtthatók ${ }^{95}$ alapján pedig 5,9-9,7\%-ban.

A McIvor modell alkalmazhatóságával kapcsolatos $\mathrm{H} 3 \mathrm{c}$ hipotézist kétváltozós logisztikus regresszióval vizsgáltam. Függő változónak a korábbiakban már leírt, a „Vállalkozások helyzetének felmérése 2009” 17. kérdése alapján létrehozott szállításraktározás-csomagolás kiszervezésének összevonásával megalkotott bináris változót választottam, független változóknak pedig a 18. és 19. kérdésekben szereplő kiszervezés melletti és elleni érveket. A logisztikus regresszió multikollinearitás és legalább 60 elemü adatbázis feltétele (Sajtos és Mitev [2007] p. 354.) teljesült. Az elemzés első fázisában az alacsony kiszervezési arány miatt 70,8\%-os viszonyítási értéket kaptam, ami azt mutatja, hogy véletlen kategorizálás esetén ekkora arányban lehetett volna eltalálni, hogy a KKV saját maga végzi-e a szállítási-raktározási-csomagolási tevékenységet. A paraméterbecslésre használt Wald statisztika szignifikáns volt. Az elemzésbe még be nem vitt független változók közül a 31. táblázatban látható, hogy 6 ellenérv önmagában nem mutatott szignifikáns hatást.

\footnotetext{
${ }^{95}$ Százalékos formában fejezik ki, hogy a független változó milyen mértékben képes a függő változót elörejelezni. (Sajtos és Mitev [2007]). A hasonló jelentésü lambdát a robosztussága (a jelen esethez is hasonlóan gyakran nulla értékü) miatt nem használtam.
} 
31. táblázat: Logisztikai tevékenységkiszervezés okainak egyedi hatásai

\begin{tabular}{|l|r|r|r|}
\hline Step 0 & \multicolumn{1}{|c|}{ Score } & \multicolumn{1}{c|}{ df } & \multicolumn{1}{c|}{ Sig. } \\
\hline Földrajzi terjeszkedés & 21,912 & 1 &, 000 \\
\hline Minőségjavulás & 61,962 & 1 &, 000 \\
\hline Költségcsökkenés & 99,921 & 1 &, 000 \\
\hline Rugalmas kapacitás & 103,368 & 1 &, 000 \\
\hline Külső szakértelem igénye & 29,586 & 1 &, 000 \\
\hline Alapvető képességfókusz & 63,144 & 1 &, 000 \\
\hline Vásárló elvárja & 15,879 & 1 &, 000 \\
\hline Beszállító elvárja & 30,291 & 1 &, 000 \\
\hline Ellenőrzés elvesztése & 4,243 & 1 &, 039 \\
\hline A szállítás, raktározás, csomagolás alapvető képesség &, 237 & 1 &, 626 \\
\hline Költségnövekedés &, 231 & 1 &, 631 \\
\hline Jobb szakértelem & 1,342 & 1 &, 247 \\
\hline Szolgáltatási színvonal nem javulna & 1,030 & 1 &, 310 \\
\hline Nem tudja, miként vegye igénybe &, 076 & 1 &, 783 \\
\hline Rejtett költségek & 14,977 & 1 &, 000 \\
\hline Függóség nő & 13,090 & 1 &, 000 \\
\hline Értékelés és ellenőrzés nehézsége & 2,338 & 1 &, 126 \\
\hline & 166,125 & 17 &, 000 \\
\hline
\end{tabular}

Forrás: saját szerkesztés

Az elemzés második fázisában a „Vállalkozások helyzetének felmérése 2009” független változóinak bevitelekor a teljes modell szignifikáns lett, ezek kombinációja a függő változó varianciájából a Nagelkerke $\mathrm{R}^{96}$ négyzet alapján 26,9\%-ot magyarázott. A kiszervezés melletti és elleni érvek összességében keveset, 6,6 százalékpontot javítottak a kiszervezés meglétének vagy hiányának helyes meghatározásában. Az összes változó együttes hatását tartalmazó táblázat alapján a költségcsökkenés, a rugalmas kapacitás, az alapvető képességekre fókuszálás, a rejtett költségek és az értékelés-ellenőrzés nehézsége maradt szignifikáns, utóbbi az $\operatorname{Exp}(B)$ értéke alapján láthatóan nem javítaná a becslést.

\footnotetext{
96 Azért ezt használtam, mivel a Cox \& Snell R négyzet (értéke 18,8\% volt) alulbecsli a valós értéket (Sajtos és Mitev [2007] p. 357.).
} 
32. táblázat: Logisztikai tevékenységkiszervezés okainak együttes hatásai

\begin{tabular}{|c|c|c|c|c|c|c|c|c|}
\hline \multirow[t]{2}{*}{ Step 1} & \multirow[t]{2}{*}{ B } & \multirow[t]{2}{*}{ S.E. } & \multirow[t]{2}{*}{ Wald } & \multirow[t]{2}{*}{ df } & \multirow[t]{2}{*}{ Sig. } & \multirow[t]{2}{*}{$\operatorname{Exp}(B)$} & \multicolumn{2}{|c|}{$\begin{array}{l}\text { 95\% C.I.for } \\
\text { EXP(B) }\end{array}$} \\
\hline & & & & & & & Lower & Upper \\
\hline Földrajzi terjeszkedés & ,697 & ,369 & 3,574 & 1 & ,059 & 2,009 & ,975 & 4,140 \\
\hline Minőségjavulás & ,286 & ,347 &, 680 & 1 & ,410 & 1,332 & ,674 & 2,630 \\
\hline Költségcsökkenés & 1,143 & ,274 & 17,413 & 1 & ,000 & 3,136 & 1,833 & 5,365 \\
\hline Rugalmas kapacitás & 1,039 & ,262 & 15,676 & 1 & ,000 & 2,826 & 1,690 & 4,727 \\
\hline $\begin{array}{l}\text { Külső szakértelem } \\
\text { igénye }\end{array}$ & ,095 & ,430 &, 048 & 1 & ,826 & 1,099 & ,473 & 2,556 \\
\hline $\begin{array}{l}\text { Alapvető } \\
\text { képességfókusz }\end{array}$ &, 514 & ,227 & 5,137 & 1 & ,023 & 1,672 & 1,072 & 2,608 \\
\hline Vásárló elvárja & ,101 & ,453 &, 050 & 1 &, 823 & 1,106 & ,455 & 2,688 \\
\hline Beszállító elvárja &, 525 & ,492 & 1,139 & 1 & ,286 & 1,691 & ,644 & 4,435 \\
\hline Ellenőrzés elvesztése & ,111 & ,290 &, 146 & 1 & ,702 & 1,117 & ,633 & 1,973 \\
\hline $\begin{array}{l}\text { A szállítás, raktározás, } \\
\text { csomagolás alapvető } \\
\text { képesség }\end{array}$ &,- 275 & ,267 & 1,060 & 1 & ,303 & ,760 &, 450 & 1,282 \\
\hline Költségnövekedés &,- 486 & ,276 & 3,104 & 1 & ,078 & ,615 & ,358 & 1,056 \\
\hline Jobb szakértelem & ,264 & ,289 & ,835 & 1 & ,361 & 1,302 & ,739 & 2,293 \\
\hline $\begin{array}{l}\text { Szolgáltatási színvonal } \\
\text { nem javulna }\end{array}$ & ,283 & ,270 & 1,096 & 1 & ,295 & 1,327 & ,781 & 2,253 \\
\hline $\begin{array}{l}\text { Nem tudja, miként } \\
\text { vegye igénybe }\end{array}$ &,- 243 & ,340 &, 513 & 1 & ,474 & ,784 & ,403 & 1,526 \\
\hline Rejtett költségek &, 544 & ,277 & 3,864 & 1 & ,049 & 1,723 & 1,002 & 2,963 \\
\hline Függőség nő & ,282 & 300 & ,886 & 1 & 347 & 1,326 &, 737 & 2,388 \\
\hline $\begin{array}{l}\text { Értékelés és ellenőrzés } \\
\text { nehézsége }\end{array}$ &,- 878 & ,345 & 6,469 & 1 & ,011 & ,415 & ,211 & ,818 \\
\hline Konstans & $-1,563$ & 132 & 140,835 & 1 & ,000 & 209 & & \\
\hline
\end{tabular}

Forrás: saját szerkesztés

A fentiek alapján megállapítható, hogy McIvor kiszervezési modellje a magyarországi mezőgazdasági, feldolgozóipari és kereskedelmi kis- és közepes vállalkozások szállítási, raktározási és csomagolási tevékenységeinek outsourcingjához csak módosítva használható. Az alapvető képességekre fókuszálás és - ide értve a tranzakciós/rejtett költségeket is - a költségcsökkentés szerepe megerösítést nyert, azonban a függőség szerepe nem, helyette a rugalmasságot kellene vizsgálni. A rugalmasság vezető szerepét egyébként egy később végzett magyarországi felmérés is megerősítette, igaz ott a logisztikai szolgáltatókat kérdezték meg arról, hogy ügyfeleik mit várnak el (Bank et al. [2010]). Magyarázó erőt tekintve a költségcsökkentés szerepe a legerősebb, amit a rugalmasság, a rejtett költségek és végül az alapvető képességek követett. 


\subsection{H4 hipotézis vizsgálata}

A H4 hipotézisem szerint a magyarországi KKV-k logisztikai szolgáltatójuk teljesítményét a költségcsökkentés, a szolgáltatásminőség és a felmerült problémák alapján ítélik meg. A vizsgálathoz a „Versenyben a világgal 2009” felmérést használtam, ahol a vállalkozások ötfokozatú skálán (1 legkevésbé fontos, 5 leginkább fontos) válaszolhattak arra, hogy a külső logisztikai szolgáltatók teljesítményének értékelésekor az egyes szempontok (K55-K56 változók) milyen súlyt kapnak. Nem volt egyértelmü, hogy a hipotézis vizsgálata inkább feltáró (exploratív) vagy megerősítő (konfirmatorikus) faktorelemzést kíván. E kettősség, a konfirmatorikus faktorelemzés komplexitása és SPSS-beli hiánya miatt a 17 szempont alapján létrejövő faktorstruktúrákat az SPSS-ben rendelkezésre álló valamennyi exploratív eljárással külön-külön megvizsgáltam, azaz:

- a faktorextrakciós módszerek közül a fökomponens-elemzéssel (PC), a legkisebb négyzetek elvével (ULS) és az általánosított legkisebb négyzetek elvével (GLS), a maximum likelihood módszerrel (ML), a fötengelyelemzéssel (PAF), az alfa és image eljárásokkal.

- valamennyi ortogonális (varimax, quartimax, equamax) és nem ortogonális forgatási módszerrel (direkt oblimin és promax).

- a hiányzó adatok listwise, pairwise és átlaghelyettesítés módszerrel történő pótlásával is.

A minta faktorelemzésre a mérete (legalább 4-5-szörösen meghaladja a változókét és számuk minimum 50-100), a Bartlett teszt és a dicséretes KMO értéke $(0,815)$ miatt alkalmas volt. Valamennyi esetben a Kaiser-kritériumot (legalább 1 sajátértékü faktorok figyelembevétele) alkalmaztam. A fötengelyelemzésnél és az image elemzésnél csak a listwise és az átlaghelyettesítés, míg az általánosított legkisebb négyzetek, a maximum likelihood és az alfa extrakció esetében csak az utóbbi vezetett eredményre ${ }^{97}$. Az esetek döntő többségében 4 faktor adódott. A 33. táblázatban találhatók azok a faktorstruktúrák, melyeket legalább öt eljárás eredményezett.

\footnotetext{
97 A listwise esetén 9999 iterációban sem sikerült a helyi minimum megtalálása vagy a kommunalitás 1 fölé ment, pairwise esetén pedig a korrelációs mátrixnak nem volt pozitív definitje.
} 
33. táblázat: Legalább öt különböző módszerrel létrejött faktorstruktúrák

\begin{tabular}{|c|c|c|c|}
\hline \multirow[b]{2}{*}{$\begin{array}{c}\text { Rotált faktorok és a } \\
\text { bennük szereplő változók }\end{array}$} & \multicolumn{3}{|c|}{ Alkalmazott megoldás } \\
\hline & $\begin{array}{l}\text { Faktor- } \\
\text { extrakciós } \\
\text { módszer }\end{array}$ & $\begin{array}{l}\text { Hiányzó } \\
\text { értékek } \\
\text { kezelése }\end{array}$ & $\begin{array}{l}\text { Faktorok rotálási } \\
\text { módszere }\end{array}$ \\
\hline \multirow{7}{*}{$\begin{array}{l}\text { I. faktorstruktúra } \\
\text { 1. faktor (K56A-K56H) } \\
\text { 2. faktor (K55D-K55I) } \\
\text { 3. faktor (K55A-K55C) } \\
\text { 4. faktor (K55J, K56I) }\end{array}$} & $\mathrm{PC}$ & $\begin{array}{c}\text { átlag- } \\
\text { helyettesítés }\end{array}$ & $\begin{array}{l}\text { varimax, oblimin, } \\
\text { quartimax, equamax és } \\
\text { promax }\end{array}$ \\
\hline & ULS & pairwise & equamax és promax \\
\hline & ULS & \multirow{5}{*}{$\begin{array}{l}\text { átlag- } \\
\text { helyettesítés }\end{array}$} & varimax, oblimin, \\
\hline & GLS & & equamax és promax \\
\hline & ML & & $\begin{array}{c}\text { oblimin, equamax és } \\
\text { promax }\end{array}$ \\
\hline & PAF & & varimax, oblimin, \\
\hline & Alfa & & equamax és promax \\
\hline \multirow{4}{*}{$\begin{array}{l}\text { II. faktorstruktúra } \\
\text { 1. faktor (K56A-K56I) } \\
\text { 2. faktor (K55D-K55J) } \\
\text { 3. faktor (K55A, K55C) } \\
\text { 4. faktor (K55B) }\end{array}$} & \multirow{2}{*}{$\mathrm{PC}$} & listwise & $\begin{array}{l}\text { varimax, oblimin, } \\
\text { quartimax és promax }\end{array}$ \\
\hline & & pairwise & $\begin{array}{l}\text { varimax, quartimax és } \\
\text { promax }\end{array}$ \\
\hline & ULS & & \\
\hline & PAF & listw1se & quartımax \\
\hline \multirow{2}{*}{$\begin{array}{l}\text { III. faktorstruktúra } \\
\text { 1. faktor }(\mathrm{K} 56 \mathrm{~A}-\mathrm{K} 56 \mathrm{I}) \\
\text { 2. faktor }(\mathrm{K} 55 \mathrm{~B}, \mathrm{~K} 55 \mathrm{D} \text {, } \\
\text { K55E, K55G, K55J) } \\
\text { 3. faktor }(\mathrm{K} 55 \mathrm{~A}, \mathrm{~K} 55 \mathrm{C} \text {, } \\
\text { K55F, K55H, K55I) }\end{array}$} & \multirow[b]{2}{*}{ Image } & $\begin{array}{c}\text { átlag- } \\
\text { helyettesítés }\end{array}$ & \\
\hline & & listwise & $\begin{array}{c}\text { varimax, equamax és } \\
\text { promax }\end{array}$ \\
\hline \multirow{5}{*}{$\begin{array}{l}\text { IV. faktorstruktúra } \\
\text { 1. fakor (K56A-K56I) } \\
\text { 2. faktor (K55A, K55C- } \\
\text { K55I) } \\
\text { 3. faktor (K55B) } \\
\text { 4. faktor (K55J) }\end{array}$} & ULS & \multirow{5}{*}{$\begin{array}{l}\text { átlag- } \\
\text { helyettesítés }\end{array}$} & \multirow{5}{*}{ quartimax } \\
\hline & GLS & & \\
\hline & ML & & \\
\hline & PAF & & \\
\hline & Alfa & & \\
\hline \multirow[b]{2}{*}{$\begin{array}{l}\text { V. faktorstruktúra } \\
\text { 1. faktor }(\mathrm{K} 56 \mathrm{~A}-\mathrm{K} 56 \mathrm{I}) \\
\text { 2. faktor }(\mathrm{K} 55 \mathrm{D}, \mathrm{K} 55 \mathrm{E} \text {, } \\
\text { K55G, K55H, K55J) } \\
\text { 3. faktor }(\mathrm{K} 55 \mathrm{~A}, \mathrm{~K} 55 \mathrm{C} \text {, } \\
\text { K55F, K55I) } \\
\text { 4. faktor }(\mathrm{K} 55 \mathrm{~B})\end{array}$} & ULS & & varimax és promax \\
\hline & PAF & listwise & $\begin{array}{c}\text { varimax, equamax és } \\
\text { promax }\end{array}$ \\
\hline
\end{tabular}

Forrás: saját szerkesztés

A leggyakrabban előforduló, azaz összesen 26 különböző módszerrel létrejött I. faktorstruktúra alapján a faktorok:

- A problémák (K56A-K56I változók), köztük a nem megfelelő információcsere, elkötelezettség (saját vállalat és szolgáltató részéről), termékismeret, fogyasztóismeret, ellenörzési mechanizmus, nem körültekintő szerződéskötés és 
időhiány. Megjegyzem, hogy a leggyakrabban előforduló összes faktorstruktúrában a problémák együtt szerepelnek.

- A készlet rendelkezésre állása, számlapontosság, értéknövelt szolgáltatások nyújtása, kapcsolattartó személy, illetve nyújtott információ minősége, valamint a sérülések száma (K55D-K55I változók). Ezt a faktort „szolgáltatásminőség” faktornak neveztem el.

- A költségcsökkentés, szállítási határidő csökkentése és a szállítások pontosságának növelése (K55A-K55C változók). Ezt a faktort „költségcsökkentés-gyors-pontos szállítás" faktornak neveztem el.

- Az egyéb elemek (K55J, K56I változók).

A fentiek alapján a negyedik hipotézis nagyrészt megerősítést nyert, azaz a magyarországi KKV-k logisztikai szolgáltatójuk teljesítményét a felmerült problémák, a szolgáltatásminőség és a költségcsökkentés alapján értékelik, bár utóbbi kiegészült a gyors és pontos szállítási szempontokkal, illetve egy külön „,egyéb” tényezők faktor is megjelent.

\subsection{H5 hipotézisek vizsgálata}

A logisztikai (saját, illetve igénybe vett) és a vállalati teljesítmény közötti összefüggésre vonatkozó H5 hipotézisek vizsgálatához a „Versenyben a világgal 2009” felmérést használtam. A mintában szereplő KKV-k vállalatvezetőinek önértékelése (V15 változók) alapján először klaszterekbe soroltam a vállalati teljesítményt. A vállalatvezetők ötfokozatú skálán (átlagszínvonal alatti - élenjáró színvonal) értékelhették a vállalatuk iparági átlaghoz képesti teljesítményét árbevétel-arányos nyereség, tőkejövedelmezőség, piaci részesedés, technológiai színvonal, menedzsment, termék/szolgáltatás minőség és egyéb sikerkritérium szerint. A klaszterelemzés előkészítéseként a kiugró elemeket (outlier) külön nem vizsgáltam, mivel a választott Likert-skálák miatt előfordulási valószínűségük kicsi. A skálák megegyeztek, így standardizálására sem volt szükség, ahogyan a páronkénti 0,9 alatti korrelációk miatt változó kizárására sem. (Sajtos és Mitev [2007])

A klaszterezést először a hierarchikus módszerrel végeztem el. Ward módszerével a négyzetes euklideszi távolságmérték felhasználásával a dendrogram (lásd a 3. függeléket), a könyökkritérium és gyakorlati megfontolások figyelembevételével 
megállapítottam, hogy a klaszterek „ideális” száma 3, illetve azt, hogy az egyéb sikerkritériumokat célszerü kizárni, mivel több mint kétszer annyi esetet lehetett így besorolni a klaszterekbe. Ezt követően K-közép klaszterrel határoztam meg a 3 klasztert, melyeket „vezető”-nek, „átlagosnál jobban teljesítő”-nek, és „stagnáló, lemaradó"-nak neveztem el.

Az elemzés második lépcsőjében a létrehozott teljesítmény-klasztereket hasonlítottam össze a logisztikai rendszer teljesítményének/hatékonyságának önértékelésével (V14j változó), illetve a kereskedelmi vezetők által az igénybe vett logisztikai szolgáltatások átlagos színvonalára adott minősítéssel (K54 változó). Utóbbit csak azon vállalkozások körében vizsgáltam, melyek valamelyik logisztikai résztevékenységüket ténylegesen kiszervezték. A vizsgálatot kereszttábla-elemzéssel végeztem el, a változókat ordinális skálájúnak tekintve. A logisztikai rendszer teljesítményét/hatékonyságát, illetve az igénybe vett logisztikai szolgáltatások átlagos színvonalát 3-3 kategóriába transzformáltam át csökkentve azt, hogy a cellákban 5 alatti értékek forduljanak elő.

$\mathrm{Az}$ igénybe vett logisztikai szolgáltatások átlagos színvonala és a teljesítményklaszterek a Khi-négyzet próba alapján függetlenek voltak, ám a logisztikai rendszer teljesítményével/hatékonyságával az összefüggés szignifikáns, igaz csak 5,1\%-os szignifikancia-szinten. A Somers-féle $\mathrm{d}^{98}$ a teljesítmény-klasztert független változónak választva 0,184 , fordított esetben 0,167 értéket értek el, ami gyenge kapcsolatot jelezett. A korrigált standardizált reziduumok legalább 2-t elérő értéke alapján szignifikánsan összefüggött:

1. az átlag alatti logisztikai rendszer-hatékonyság és a stagnáló-lemaradó vállalati teljesítmény, illetve

2. az átlag feletti logisztikai rendszer-hatékonyság és a vezető vállalati teljesítmény.

\footnotetext{
${ }^{98}$ Választását az indokolta, hogy a teljesítményklasztereket ordinális skálájúnak tekintettem és a Somers féle d bármely kereszttábla-méret esetén használható. Értéke -1 és +1 közötti lehet, az 1-hez közeli érték erős, a 0-hoz közeli érték gyenge kapcsolatot, illetve a kapcsolat hiányát jelenti. (Sajtos és Mitev [2007], p. 145.)
} 
34. táblázat: Vállalati teljesítményklaszterek és logisztikai rendszer hatékonyságának összefüggései

\begin{tabular}{|c|c|c|c|c|c|c|}
\hline & \multicolumn{3}{|c|}{ Logisztikai rendszer hatékonysága } & \multirow[b]{2}{*}{ Összesen } \\
\hline & & & Átlag alatti & Közepes & $\begin{array}{l}\text { Átlag } \\
\text { feletti }\end{array}$ & \\
\hline \multirow{6}{*}{ 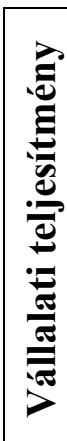 } & \multirow[b]{2}{*}{$\begin{array}{l}\text { Stagnáló, } \\
\text { lemaradó }\end{array}$} & Száma & 14 & 41 & 26 & 81 \\
\hline & & $\begin{array}{r}\text { Korrigált } \\
\text { reziduumok }\end{array}$ & 2,0 &, 5 & $-1,8$ & \\
\hline & \multirow{2}{*}{$\begin{array}{c}\text { Átlagosnál } \\
\text { jobban } \\
\text { teljesítő }\end{array}$} & Száma & 8 & 44 & 32 & 84 \\
\hline & & $\begin{array}{r}\text { Korrigált } \\
\text { reziduumok }\end{array}$ &,- 8 & ,9 &,- 4 & \\
\hline & \multirow[b]{2}{*}{ Lemaradó } & Száma & 3 & 20 & 28 & 51 \\
\hline & & $\begin{array}{r}\text { Korrigált } \\
\text { reziduumok }\end{array}$ & $-1,5$ & $-1,5$ & 2,5 & \\
\hline
\end{tabular}

Forrás: saját szerkesztés

A H5 hipotézisek tehát csak részben igazolódtak be. A kis- és középvállalkozások teljesítménye és az igénybe vett logisztikai szolgáltatás minősége között nem volt kapcsolat, ám a logisztikai rendszer hatékonyága/teljesítménye és a vállalati teljesítmény között igen, igaz csak 5,1\%-os szignifikanciaszinten. Az eredmény értékelésénél arra is tekintettel kell lenni, hogy a korábbi kutatásokkal szemben jelen kutatásnál a vállalati és a logisztikai teljesítmény értékelése nem pénzügyi és logisztikai mutatókon, hanem a vállalatvezetők önértékelésén alapult.

\subsection{H6 hipotézis vizsgálata}

A H6 hipotézissel a magyarországi KKV-k vezetőinek logisztikai felfogását vizsgáltam, azaz, hogy az beszerzés-centrikus-e és ezeket a funkciókat másodlagosnak tekintik-e.

A „Versenyben a világgal 2009” felmérésben a vállalkozások vezérigazgatója, kereskedelmi, pénzügyi és termelési vezetője ötfokozatú Likert-skálán jelölhette meg, hogy a müködés 18 részterületének ${ }^{99}$ milyen tényleges súlya van az összvállalati müködés sikere szempontjából (M1 változók). Az összetartozó mintákra tekintettel a beszerzés, logisztika és készletgazdálkodás azonos vállalatméretnél történő összehasonlítását a normalitás fennállása esetén összetartozó mintás t-próbákkal, annak hiányában Wilcoxon-próbákkal végeztem el.

\footnotetext{
99 Felső vezetés, kereskedelem/marketing, kontrolling, kutatás-fejlesztés, szervezetfejlesztés, termelés, értékesítés, beszerzés, logisztika, készletgazdálkodás, emberi erőforrás menedzsment, számvitel, pénzügy, bérgazdálkodás, minőségbiztosítás, információmenedzsment, stratégiai tervezés
} 
35. táblázat: A beszerzés, készletgazdálkodás és logisztika szerepe az összvállalati sikerben, vállalatméret és különböző vállalati vezetők szerint

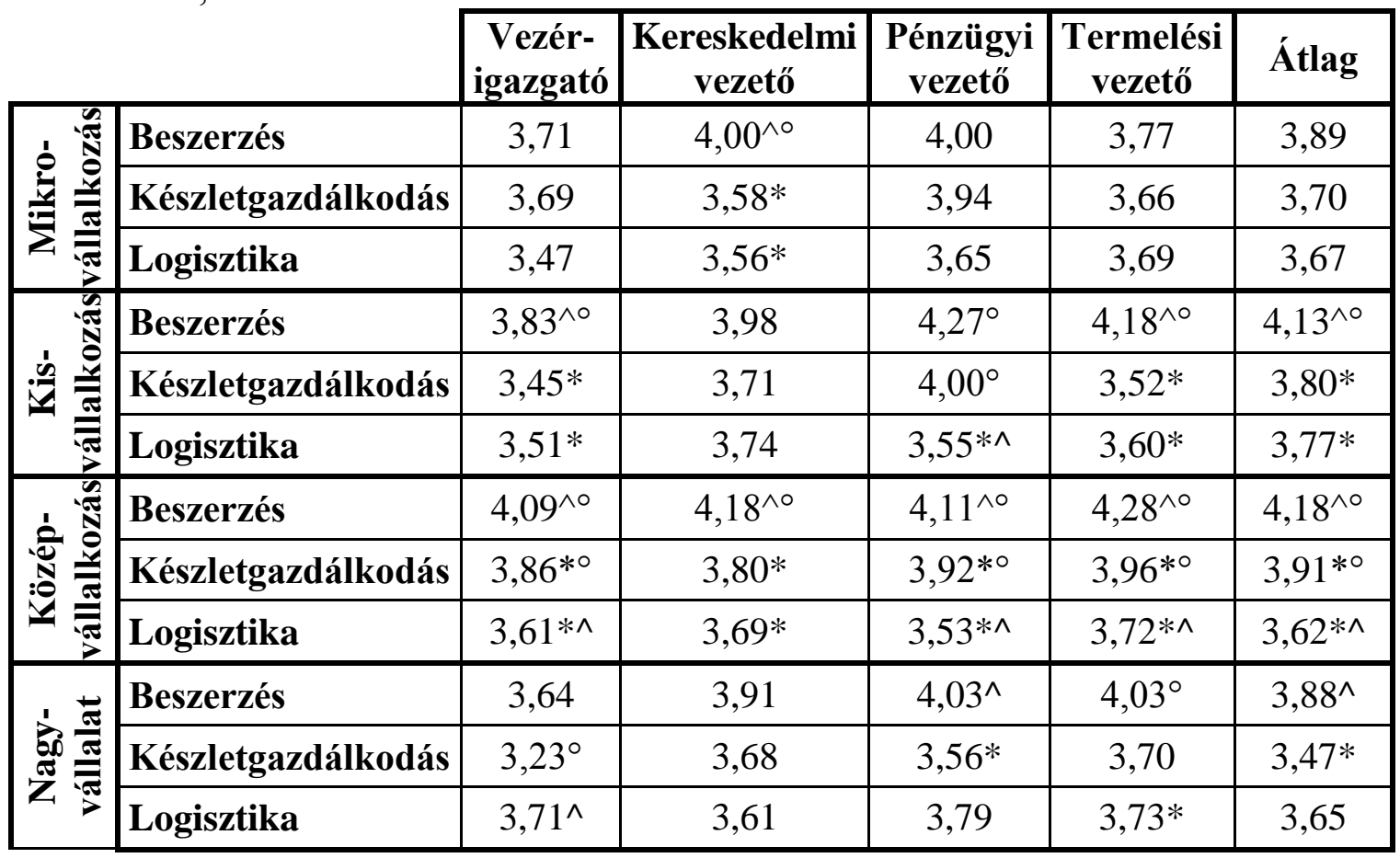

*szignifikánsan különbözik a beszerzés értékétől

^ szignifikánsan különbözik a készletgazdálkodás értékétől

○ szignifikánsan különbözik a logisztika értékétől

Forrás: saját szerkesztés

A H6 hipotézis beszerzési-piroritásra vonatkozó első felével kapcsolatban elmondható, hogy:

- A különböző KKV-k vezetői a logisztikai résztevékenységek közül egy kivétellel a beszerzés összvállalati sikerben betöltött szerepét értékelték a legmagasabbra, ezért a hazai kis- és középvállalkozások beszerzés-prioritású logisztika felfogása megerősítést nyert.

- A mikrovállalkozásoknál a vezetők a három területet szerepét az összvállalati sikerben szignifikánsan homogénnek tekintették, egyedül a kereskedelmi vezetőik tartották fontosabbnak a beszerzést a másik két logisztikai részterületnél. Ez a felfogás a kisvállalkozásoknál a vezérigazgatóra és a termelési, illetve részben a pénzügyi vezetőjére volt jellemző. A középvállalkozásoknál valamennyi vezetőnél a beszerzés-készletgazdálkodás-logisztika volt a prioritási sorrend, mely csak egy esetben nem különbözött szignifikánsan. A nagyvállalatoknál már integráltabb felfogás és a készletgazdálkodás a háttérbe szorulása volt tapasztalható. A szignifikáns különbségek megléte alapján tehát megállapítható, hogy a hazai KKV-k a mikrovállalkozások kivételével a logisztikai integráció hiánya a jellemző. A 
mikrovállalkozások körében az eltérést vélhetően a különböző funkciók kis méret miatti együttléte (,embrionális integráltság”) magyarázhatja.

A H6 hipotézis másik fele arra vonatkozott, hogy a három logisztikai részterület (beszerzés, logisztika, készletgazdálkodás) jelentősége elmarad a többi 15 müködési területétől. Ennek sorrendjét mikro-, kis-, közép- és nagyvállalatok és azok vezetőinek körében külön-külön is vizsgáltam. Az eredményeket tartalmazó táblázatokat terjedelmi okokból a 3. függelékben helyeztem el. A Kolmogorov-Szmirnov próbákkal ellenőrzött normalitás fennállása esetén összetartozó mintás t-próbát, egyéb esetekben Wilcoxon próbát használtam. Az alábbi táblázatban látható rangsorbeli helyezések nem pontosan tükrözik a valós helyzetet (ti. minden esetben a logisztikai résztevékenységekre adott átlag legalább 3,23-at ér el), azaz, hogy a készletmenedzsment és a logisztika összvállalati sikerben a vállalatvezetők szerint az utolsók között szerepel, nála csak a $\mathrm{K}+\mathrm{F}$ és a szervezet-fejlesztés szerepét értékelik kevesebbre.

36. táblázat: A logisztikai részterületek sikerben betöltött szerepének vezetők általi rangsorban elfoglalt helyének minimuma, maximuma vállalatméret szerint

\begin{tabular}{|l|c|c|c|c|}
\hline & $\begin{array}{c}\text { Mikro- } \\
\text { vállalkozások }\end{array}$ & $\begin{array}{c}\text { Kis- } \\
\text { vállalkozások }\end{array}$ & $\begin{array}{c}\text { Közép- } \\
\text { vállalkozások }\end{array}$ & $\begin{array}{c}\text { Nagy- } \\
\text { vállalatok }\end{array}$ \\
\hline Beszerzés & $6-11 .\left(8 .^{100}\right)$ & $4-10 .(6)$. & 5-7. (6.) & 7-14. (10.) \\
\hline Logisztika & $13-16 .(14)$. & $12-14 .(14)$. & $13-14 .(13)$. & $12-15 .(15)$. \\
\hline Készletgazdálkodás & $8-14 .(13)$. & $9-15 .(13)$. & $9-10 .(10)$. & $14-16 .(16)$. \\
\hline
\end{tabular}

Forrás: saját szerkesztés

A pontos helyzetet jobban mutatja, ha a szignifikáns különbségek szerinti sorrendet vesszük figyelembe, azaz a szignifikánsan nem különböző funkciók ugyanazt a helyezést kapják. A vállalati vezetők által adott értékek ugyanis szignifikánsan nem minden esetben különböztek egymástól. A szignifikáns különbségek (a nem különbözőket azonos sorszámmal ellátva) alapján újraalkotott sorrend ugyan kedvezőbben alakul (lásd a 37. táblázat), de azon nem változtat, hogy a KKV-k vezetői a logisztikai résztevékenységeknél általában csak a $\mathrm{K}+\mathrm{F}$ és a szervezet-fejlesztés sikerben betöltött szerepét értékelték alacsonyabbra.

100 zárójelben az átlagos pozíció 
37. táblázat: A logisztikai részterületek sikerben betöltött szerepének vezetők általi rangsorban elfoglalt helyének (szign. korrigált) minimuma, maximuma vállalatméret szerint

\begin{tabular}{|l|c|c|c|c|}
\hline & $\begin{array}{c}\text { Mikro- } \\
\text { vállalkozások }\end{array}$ & $\begin{array}{c}\text { Kis- } \\
\text { vállalkozások }\end{array}$ & $\begin{array}{c}\text { Közép- } \\
\text { vállalkozások }\end{array}$ & $\begin{array}{c}\text { Nagy- } \\
\text { vállalatok }\end{array}$ \\
\hline Beszerzés & $1-5 .(4)$. & $3-5 .(6)$. & $3-5 .(3)$. & $2-7 .(5)$. \\
\hline Logisztika & $4-7 .(5)$. & $8-10 .(9)$. & $9-12 .(12)$. & $5-7 .(6)$. \\
\hline Készletgazdálkodás & $4-9 .(4)$. & $3-11 .(9)$. & $6-8 .(8)$. & $4-13 .(8)$. \\
\hline
\end{tabular}

Forrás: saját szerkesztés 


\section{A disszertáció eredményei}

A kis- és középvállalkozások logisztikai gyakorlatának eddigi legszélesebb körü szakirodalmi feltárására épülő kutatásomban kiemelten vizsgáltam a logisztikai költségeket és tevékenységkiszervezést. A közel kétezer KKV-re kiterjedő „Vállalkozások helyzetének felmérése 2009” adatfelvételének már a leíró statisztikái is érdekes eredményekre vezettek:

- Megállapítottam, hogy a magyarországi kis- és közepes vállalkozások 43,86\%-a nulla logisztikai összköltségről adott számot, az egyes részköltségeknél pedig ez az arány legalább 58,98\%-ot ért el. A kis- és középvállalkozások logisztikai költségszintje - különösen a nagyobb alkalmazotti létszámú KKV-ké - magasabb volt a hazai és nemzetközi kutatások alapján vártnál és a mexikói értékekhez állt a legközelebb. A magyarországi KKV-re jellemző átlagosan 18,86\%-os logisztikai összköltségszintből a legnagyobb arányban a szállítási, a raktározási és nem várt módon az adminisztrációs költségek részesedtek. A hazai KKV-k körében a minél nagyobb a vállalkozás, annál kisebb logisztikai költségarány hüvelykujj-szabálynak éppen az ellenkezője volt tapasztalható. A vártnak megfelelően alakult az, hogy ágazatok közül a mezőgazdasági, a feldolgozóipari és a kereskedelemi KKV-k rendelkeztek a legmagasabb átlagos logisztikai költségszintekkel.

- A magyarországi KKV-k logisztikai tevékenységkiszervezési szintjét tekintve ellentmondásos eredményekre jutottam. A „Vállalkozások helyzetének felmérése 2009” alapján a logisztikai tevékenységkiszervezési szintje viszonylag alacsony volt. E felmérés szerint a magyarországi kis- és középvállalkozások 15,03\%-a a szállítás-rakománykezelést, 6,69\%-uk a szállítmányozást, 4,68\%-uk a logisztikai informatikát, 4,00\%-uk a raktározás-tárolást, 3,07\%-uk a rendeléskezelést, a csomagolást pedig 1,80\%-uk helyezte ki. A készletmenedzsment kiszervezése olyan kevés esetben fordult elő, hogy a további vizsgálatokból kizártam. Ezzel szemben a „Versenyben a világgal 2009” kutatás eredményei alapján a szállítmányozásfuvarozást a megkérdezett KKV-k 70,91\%-a, a raktározást 25,00\%-a, a készletgazdálkodást pedig 20,12\%-a helyezte ki. Az eltérést a feldolgozóipari és a nagyobb méretü KKV-k magasabb aránya magyarázhatja. A „Vállalkozások helyzetének felmérése 2009" minta alapján a logisztikai outsourcingot végrehajtó magyarországi KKV-k közel fele egyszerre több résztevékenységet is kiszervezett. Ezek közül a leggyakrabban a szállítás-szállítmányozást (29,35\%), a szállítás- 
raktározást $\quad(7,07 \%), \quad$ a szállítás-raktározás-szállítmányozást $\quad(7,07 \%)$ és a szállítmányozás-logisztikai informatikát (4,35\%).

- A logisztikai részköltségek és tevékenységkiszervezések egymásra gyakorolt hatásánál a szállítás kiszervezése és a szállítási költség, illetve a logisztikai összköltség, valamint a raktározás kiszervezése és a raktározási költség, a csomagolás kiszervezése és a csomagolási költség között közepes, az összes többi esetben pedig gyenge korrelációt találtam.

A H1 hipotéziseimnél a „Vállalkozások helyzetének felmérése 2009” adatbázist és kereszttábla elemzéseket használva igazoltam, hogy a szállítási, a raktározási, a csomagolási, a készlettartási, a készlethiány, a logisztikai adminisztrációs költségszint és a logisztikai összköltségarány szempontjából - a készlethiány költség kivételével - a vállalatméret és az ágazat a két legfontosabb kontingencia-tényező. A hatféle logisztikai résztevékenységek kiszervezési szintjére vonatkozó H1b hipotéziseknél ugyanez csak a szállításra és a szállítmányozásra volt igaz; a raktározás esetében a fö értékesítés helye, a csomagolás és rendeléskezelés kiszervezése esetén a településtípus, a logisztikai informatika kiszervezésénél pedig a vállalkozás egyéni vagy társas jellege vette át az ágazat szerepét. A kontingencia-tényezők és a logisztikai költségarányok, valamint a kiszervezési szintek közötti vegyes kapcsolatok gyenge-közepesnek minősültek, melyek tovább csökkentek, amikor a vizsgálatot a mezőgazdasági, feldolgozóipari és kereskedelemi KKV-kre szükítettem le, sőt több esetben a függőség is megszünt.

A második hipotézisem vizsgálatakor „Vállalkozások helyzetének felmérése 2009” adatbázis reprezentativitását kihasználva megerősítést nyert, hogy a társas kis- és középvállalkozások szállítási és raktározási kereslete jelentős mértékü. Ebből a jelenleg saját körben megvalósuló tevékenységvégzés a fuvarozó főtevékenységű vállalkozások piacának 1,97-szeresét, a raktározással foglalkozóknak 3,53-szorosát érte el. Az is bizonyítást nyert, hogy a keresletnövekmény csak látens, mivel a vizsgált KKV-k legalább 7/8-a az elkövetkezendő években nem számít (vagy nem tud) e téren változásra.

A második hipotézisben használt módszerrel azt is megállapítottam, hogy a magyarországi társas kis- és középvállalkozások logisztikai összköltsége 2009-ben 6143,734 milliárd Ft-ot ért el. Ez GDP arányosan 22,97\% szintnek felel meg, mely a hasonló időpontban készült finn és dél-afrikai kutatások arányaival $(8,7 \%$, illetve 
14,7\%) összehasonlítva igen magas, különösen úgy, hogy sem a nagyvállalatok, sem pedig az egyéni vállalkozások értékeit nem tartalmazza.

A harmadik hipotéziseimnél a szállítás, raktározás és csomagolás kiszervezése melletti és elleni érveket vizsgálva - szakítva az eddigi KKV logisztikai outsourcing kutatásokban alkalmazott gyakorisági elemzésekkel - kereszttábla-elemzéseket és bináris logisztikus regressziót használtam. A „Vállalkozások helyzetének felmérése 2009” adatbázis alapján:

a) Kimutattam, hogy a logisztikai tevékenységkiszervezés melletti és elleni érvek nem voltak teljesen konzisztensek és azt is, hogy a magyarországi feldolgozóipari KKVk 42,65\%-a, a mezőgazdaságiak 33,33\%-a, a kereskedők 24,67\%-a tekintette alapvető képességének a szállítást, raktározást és csomagolást. A mezőgazdasági, feldolgozóipari és kereskedelmi mikro- és kisvállalkozások méretük növekedésével egyre nagyobb mértékben tartották alapvető képességnek a szállítást, a raktározást és a csomagolást, ám a középvállalkozások esetében ez megváltozott. Ehhez vélhetően a nagyobb specializáció és a fötevékenységre történő erősebb koncentrálás vezetett. A logisztikai tevékenységek kiszervezésének tranzakciós költségei alapján úgy tünt, hogy még a középvállalkozások sem voltak elég nagyok a méretgazdaságosság eléréshez.

b) A KKV-k logisztikai kiszervezés szintje és az outsourcing elleni érvek között egy kivétellel gyenge, míg a mellette szóló érvek szerint közepes erősségü kapcsolatot találtam. A KKV-k szállítás, raktározás és csomagolás kiszervezése kapcsán a legerősebb magyarázatot a rugalmas kapacitás és a költségcsökkentés jelentette, melyet a minőségjavulás, illetve az alapvető képességekre fókuszálás követett. A H3b hipotézisben feltételezett költségcsökkentés, alapvető képességekre fókuszálás és rugalmas kapacitás mellett a logisztikai tevékenységkiszervezés magyarázatai között fontos új szempontként jelent meg a minőség javítása. Mindazonáltal a négy fő tényező önmagában is csak kis mértékben magyarázta a szállítás, raktározás és csomagolás kiszervezését.

c) A H3c hipotézis során kimutattam, hogy McIvor modellje a magyarországi mezőgazdasági, feldolgozóipari és kereskedelmi kis- és közepes vállalkozások szállítási, raktározási és csomagolási tevékenységeinek kiszervezéséhez csak módosítva adaptálható. Az alapvető képességekre fókuszálás és - ide értve a tranzakciós költségeket is - a költségcsökkentés szerepe megerősítést nyert, azonban 
a függőség szerepe nem, helyette a rugalmasságot kellene vizsgálni. Magyarázó erőt tekintve a költségcsökkentés szerepe volt a legerősebb, amit a rugalmasság, a rejtett költségek és az alapvető képességek követtek.

A negyedik hipotézisemnél a „Versenyben a világgal 2009” adatai alapján az SPSS statisztikai programcsomagban elérhető valamennyi faktorelemzési eljárás felhasználásával megerősítést nyert, hogy a magyarországi KKV-k logisztikai szolgáltatójuk teljesítményét a felmerült problémák, a szolgáltatásminőség, a költségcsökkentés-szállítás, illetve „egyéb” tényezők alapján ítélik meg.

A „Versenyben a világgal 2009” adatai alapján a kis- és középvállalkozások teljesítménye és az általuk igénybe vett logisztikai szolgáltatás minősége között nem találtam kapcsolatot. A vállalati teljesítmény és a logisztikai rendszer hatékonyága/teljesítménye között viszont igen, igaz csak 5,1\%-os szignifikanciaszinten. E kapcsolat gyengének bizonyult, ráadásul a vállalati teljesítmény valamivel erősebben hatott a logisztikaira, mint fordítva. A kapcsolat az átlag alatti logisztikai rendszerhatékonyság és a stagnáló-lemaradó vállalati teljesítmény, illetve az átlag feletti logisztikai rendszer-hatékonyság és a vezető vállalati teljesítmény között szignifikáns volt. Ezen eredmény értékelésénél arra is tekintettel kell lenni, hogy a korábbi kutatásokkal szemben az értékelés nem pénzügyi és logisztikai mutatókon, hanem a vállalatvezetők önértékelésén alapult.

A hatodik hipotézis összetartozó mintás t-próbákkal és Wilcoxon próbákkal történő vizsgálatakor a „Versenyben a világgal 2009” adatai alapján megerősítést nyert, hogy magyarországi KKV-k vezetőinek logisztika felfogása beszerzés-prioritású és a mikrovállalkozások kivételével a logisztikai integráció hiánya jellemző rájuk. Az is kiderült, hogy az összvállalati sikerben a vállalatvezetők a logisztikát és a készletgazdálkodást az utolsó helyekre sorolják és ezeknél csak a $\mathrm{K}+\mathrm{F}$ és a szervezetfejlesztés szerepét értékelik alacsonyabbra.

A kutatási kérdésemre adható válasz a fentiek alapján sajnos az, hogy a logisztikát a kisés középvállalkozások vezetői másodlagos funkciónak tekintik. Mindazonáltal a KKV-k logisztikai rendszerének hatékonysága és vállalati teljesítménye, ha gyengén is, de 
összefügg és ez reményt ad arra, hogy a jövőben a másodlagos funkciós státusz megváltozhat.

Úgy vélem, hogy a jövőbeni kutatásoknál a feldolgozóipari és a kereskedelmi mellett a mezőgazdasági kis- és középvállalkozásokra lenne érdemes kiemelt figyelmet fordítani. A KKV-k logisztikai gyakorlatának vizsgálatában még számos fehér folt van, ezek közül véleményem szerint a KKV-k nemzetköziesedésének logisztikai vonatkozásai, a hagyományos eszközök használata, illetve a logisztikai együttmüködések kutatása tủnik a legígéretesebbnek. Remélhetőleg e kihívásokkal teli területet más doktoranduszok is kutatásra érdemesnek találják, és nem kell újabb húsz évet várni a témával foglalkozó disszertáció megszületésére. 


\title{
Függelékek
}

1. függelék: „Vállalkozások helyzetének felmérése 2009” kutatás felhasznált kérdései

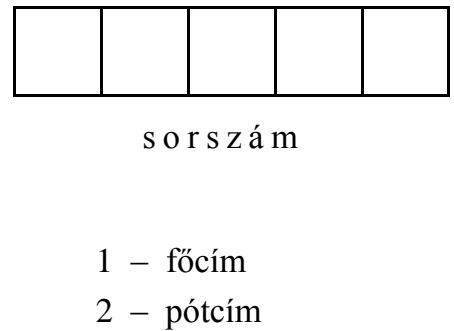

\section{Vállalkozások helyzetének felmérése}

2009. szeptember-október

A válaszadás önkéntes!

Település neve: Budapesten kerület:
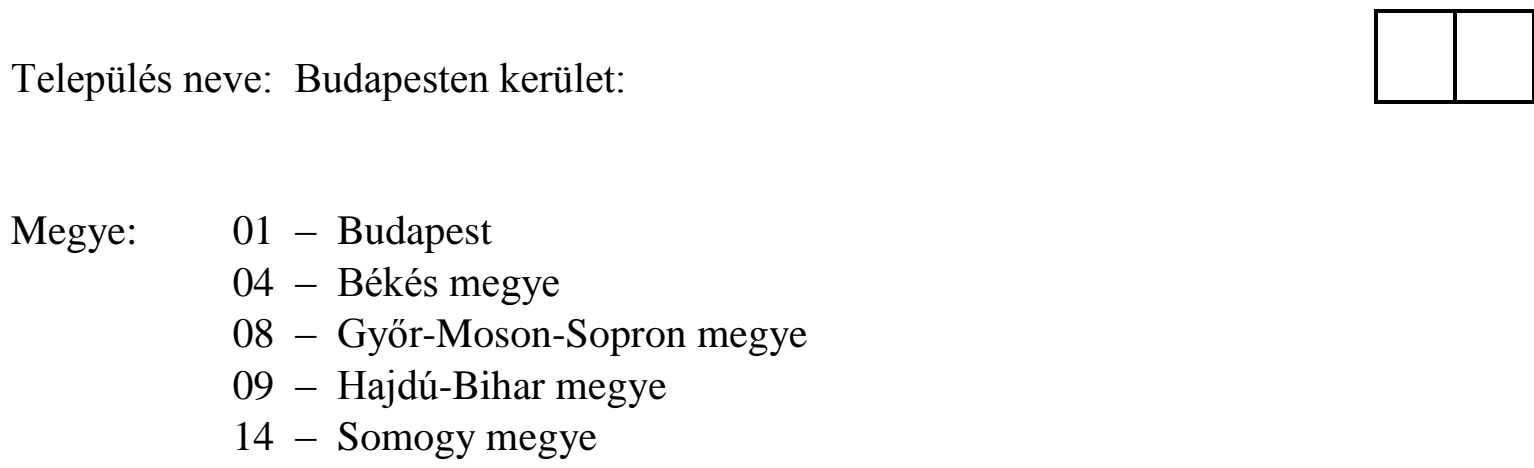

\begin{abstract}
Kijelentem, hogy az általam kezelt és felvett adatok megfelelnek a valóságnak, azokat bizalmasan kezelem, és csak a kutatásban illetékes személynek adom át.
\end{abstract}

Kérdező aláírása:

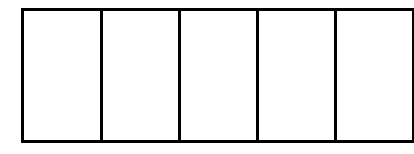

kérdezői

igazolványszám

KÉRDEZÉS KEZDETE: 2009. hó nap óra perctől 
3. Mikor alakult meg vállalkozása? (az alapítás éve) .évben

$9-\mathrm{NT} \quad \mathrm{X}-$

4. Mi a vállalkozás jogi formája?

$\begin{array}{ll}1 \text { - egyéni vállalkozás } & 5 \text { - Részvénytársaság } \\ 2-\mathrm{Kkt} & 6 \text { - Szövetkezet } \\ 3-\mathrm{Bt} & 7-\text { Egyéb } \\ 4-\mathrm{Kft} & 9-\mathrm{NT} \quad \mathrm{X}-\end{array}$

5. Nevezze meg a fö tevékenységét!

ÍRD LE, ÉS KÓDOLD IS!

\section{CSAK 1 VÁLASZ!}

01 - Mezőgazdaság, vad-, erdő-, halgazdálkodás

02 - Bányászat

03 - Feldolgozóipar

04 - Villamosenergia-, gáz-, gőz-, vízellátás

05 - Építőipar

06 - Kereskedelem, javítás
07 - Szálláshely-szolgáltatás, vendéglátás

08 - Szállítás, raktározás, posta, távközlés

09 - Pénzügyi közvetítés

10 - Ingatlan-ügyletek, gazdasági szolgáltatás

11 - Oktatás

12 - Egészségügyi, szociális ellátás

13 - Egyéb közösségi, személyi szolgáltatás

99 - NT X -

\section{Az Ön vállalkozása túlnyomórészt hova értékesít (szolgáltat)?}

1 - Erre a településre (ahol a székhelye van),

2 - nem erre a településre, de ezen a megyén belül,

3 - megyén kívül, de Magyarországra, vagy

4 - külföldre?

$9-\mathrm{NT} \quad \mathrm{X}-$
FIGYELEM! BUDAPEST NEM RÉSZE PEST MEGYÉNEK, EZÉRT BUDAPESTI KÉRDEZÉS ESETÉN A 2-ES KÓD NEM HASZNÁLHATÓ! LD. ÚTMUTATÓ! 
13. Az idei költségeinek körülbelül hány százalékát tették ki a következők?

\begin{tabular}{|ll|r|}
\cline { 2 - 2 } \multicolumn{1}{l|}{} & százalék \\
\hline a. & Szállítás és rakománykezelés & $\%$ \\
\hline & Raktározás, tárolás (saját raktár müködtetése, vagy ilyen szolgáltatás & $\%$ \\
\hline c. & Csomagolás & $\%$ \\
\hline d. & Készletek éves átlagos értéke (beszerzési áron) & $\%$ \\
\hline e. & Készlethiány miatt meghiúsult megrendelés, alacsonyabb termelés/szolgáltatás & $\%$ \\
\hline f. & A fenti tevékenységek adminisztrációja & $\%$ \\
\hline
\end{tabular}

17. A következő tevékenységek hány százalékát végzik jelenleg külső szolgáltatók az Önök számára: maximum 5 százalékát; 5-nél több, de maximum 25\%-át; 25-nél több, de maximum 50\%-át, maximum $75 \%$-át; vagy több, mint $75 \%$ át?

MIUTÁN VÁLASZOLT: Az elkövetkezendő 5 évben hogyan fog változni ez az arány? Az 1-es osztályzat most azt jelentse azt, hogy erősen csökkenni fog, az 5ös pedig hogy jelentősen növekedni fog az aránya. (Természetesen a közbülső osztályzatokat is használhatja.)

\begin{tabular}{|c|c|c|c|c|c|c|c|c|c|c|c|c|c|c|c|}
\hline \multirow[b]{2}{*}{ SORONKÉNT KÉRDEZD! } & \multicolumn{7}{|c|}{$\begin{array}{c}\text { KÜLSŐ SZOLGÁLTATÓK } \\
\text { JELENLEG }\end{array}$} & & \multicolumn{6}{|c|}{$\begin{array}{c}\text { VÁLTOZÁS A } \\
\text { KÖVETKEZŐ } 5 \text { ÉVBEN }\end{array}$} & \\
\hline & $\begin{array}{l}\text { nem } \\
\text { vég- } \\
\text { zik }\end{array}$ & $\max$ & $\begin{array}{c}\max \\
25 \%\end{array}$ & $\begin{array}{c}\max \\
\dot{50 \%}\end{array}$ & $\begin{array}{c}\max \\
75 \%\end{array}$ & $\begin{array}{c}\text { több } \\
\text { mint } \\
75 \% \\
\end{array}$ & $\begin{array}{l}\mathrm{N} \\
\mathrm{T}\end{array}$ & \multicolumn{6}{|c|}{\begin{tabular}{|c|} 
OSZTÁLYYZAT \\
$1=$ erösen csökkenni fog \\
$5=$ jelentősen növekedni \\
fog
\end{tabular}} & $\begin{array}{l}\mathrm{N} \\
\mathrm{T}\end{array}$ & \\
\hline $\begin{array}{l}\text { a. Szállítás és } \\
\text { rakománykezelés }\end{array}$ & 0 & 1 & 2 & 3 & 4 & 5 & 9 & $X$ & 1 & 2 & 3 & 4 & 5 & 9 & $\mathrm{X}$ \\
\hline b. Raktározás, tárolás & 0 & 1 & 2 & 3 & 4 & 5 & 9 & $\mathrm{X}$ & 1 & 2 & & 4 & 5 & 9 & $\mathrm{X}$ \\
\hline c. Csomagolás & 0 & 1 & 2 & 3 & 4 & 5 & 9 & $X$ & 1 & 2 & 3 & 4 & 5 & 9 & $\mathrm{X}$ \\
\hline d. Szállítmányozás & 0 & 1 & 2 & 3 & 4 & 5 & 9 & $\mathrm{X}$ & 1 & 2 & & 4 & 5 & 9 & $\mathrm{X}$ \\
\hline e. Rendeléskezelés & 0 & 1 & 2 & 3 & 4 & 5 & 9 & $\mathrm{X}$ & 1 & 2 & & 4 & 5 & 9 & $\mathrm{X}$ \\
\hline f. Készletmenedzsment & 0 & 1 & 2 & 3 & 4 & 5 & 9 & $\mathrm{X}$ & 1 & 2 & & & 5 & 9 & $\mathrm{X}$ \\
\hline $\begin{array}{l}\text { g. A fenti tevékenységek } \\
\text { végzéséhez szükséges } \\
\text { informatikai } \\
\text { rendszerek }\end{array}$ & 0 & 1 & 2 & 3 & 4 & 5 & 9 & $X$ & 1 & 2 & 3 & 4 & 5 & 9 & $X$ \\
\hline
\end{tabular}

18. Ön szerint a következő érvek közül melyek szólnak a szállítási, raktározási, rakománykezelési, csomagolási tevékenységeik kihelyezése mellett?

\begin{tabular}{|c|c|c|c|c|}
\hline & igen & nem & NT & \\
\hline a. Vállalkozásuk (földrajzilag) terjeszkedik. & 1 & 2 & 9 & $\mathrm{X}$ \\
\hline $\begin{array}{l}\text { b. Ezen tevékenységek minőségét javítja a külső szolgáltató } \\
\text { igénybevétele. }\end{array}$ & 1 & 2 & 9 & $\mathrm{X}$ \\
\hline c. Ezen tevékenységekhez kapcsolódó költségek csökkennek. & 1 & 2 & 9 & $\mathrm{X}$ \\
\hline $\begin{array}{l}\text { d. Vállalkozásuknak rugalmas szolgáltatási kapacitásokra van } \\
\text { szüksége. }\end{array}$ & 1 & 2 & 9 & $\mathrm{X}$ \\
\hline $\begin{array}{l}\text { e. Vállalkozásuknak ezen tevékenységek tekintetében külső } \\
\text { szakértelemre van szüksége. }\end{array}$ & 1 & 2 & 9 & $\mathrm{X}$ \\
\hline
\end{tabular}




\begin{tabular}{|ll|l|l|l|l|}
\hline f. & Vállalkozásuk csak az alapvető tevékenységeire fókuszál. & 1 & 2 & 9 & $\mathrm{X}$ \\
\hline g. & A vásárlóik elvárják Önöktől a külső szolgáltató bevonását. & 1 & 2 & 9 & $\mathrm{X}$ \\
\hline h. & A beszállítóik elvárják Önöktől a külső szolgáltató bevonását. & 1 & 2 & 9 & $\mathrm{X}$ \\
\hline
\end{tabular}

\section{9. És a következő érvek közül melyek szólnak a szállítási, raktározási,} rakománykezelési, csomagolási tevékenységeik kihelyezése ellen?

\begin{tabular}{|c|c|c|c|}
\hline & 1gen & nem & NT \\
\hline $\begin{array}{l}\text { a. A kihelyezés a folyamatok feletti ellenőrzés elvesztését } \\
\text { jelenti. }\end{array}$ & 1 & 2 & 9 \\
\hline $\begin{array}{l}\text { b. A fenti tevékenységek vállalkozásuk alapvető képességeihez } \\
\text { tartoznak. }\end{array}$ & 1 & 2 & 9 \\
\hline $\begin{array}{l}\text { c. Az e tevékenységekhez kapcsolódó költségeket a kihelyezés } \\
\text { nem csökkenti. }\end{array}$ & 1 & 2 & 9 \\
\hline $\begin{array}{l}\text { d. } \quad \text { Vállalkozásuk fenti tevékenységekhez kapcsolódó } \\
\text { szakértelme jobb, mint a szolgáltatóké. }\end{array}$ & 1 & 2 & 9 \\
\hline $\begin{array}{l}\text { e. A fenti tevékenységek kihelyezése alapvetően nem javítaná a } \\
\text { szolgáltatás színvonalát. }\end{array}$ & 1 & 2 & 9 \\
\hline $\begin{array}{l}\text { f. Vállalkozásuk nem tudja, miként vegye igénybe a fent } \\
\text { felsorolt szolgáltatásokat. }\end{array}$ & 1 & 2 & 9 \\
\hline g. Ezen tevékenységek kihelyezésének rejtett költségei vannak. & 1 & 2 & 9 \\
\hline $\begin{array}{l}\text { h. A szolgáltatótól való függőségük nő a fenti tevékenységek } \\
\text { kihelyezésével. }\end{array}$ & 1 & 2 & 9 \\
\hline i. Nehéz a szolgáltatási színvonalat értékelni és ellenőrizni. & 1 & 2 & 9 \\
\hline
\end{tabular}

23. Együttmüködik-e más vállalkozással, vagy vállalkozásokkal a következő területeken?

\begin{tabular}{|ll|c|c|c|c|}
\cline { 3 - 6 } \multicolumn{1}{l|}{} & igen & nem & NT & \\
\hline a. & közös beszerzés & 1 & 2 & 9 & $\mathrm{X}$ \\
\hline b. & közös értékesítés & 1 & 2 & 9 & $\mathrm{X}$ \\
\hline c. & közös termelés & 1 & 2 & 9 & $\mathrm{X}$ \\
\hline d. & közös fejlesztés & 1 & 2 & 9 & $\mathrm{X}$ \\
\hline e. & közös pályázat & 1 & 2 & 9 & $\mathrm{X}$ \\
\hline
\end{tabular}


26. Mi különbözteti meg az Ön vállalkozását versenytársai vállalkozásától?

01 - alacsonyabb ár

02 - jobb minöség

03 - nagyobb választék

04 - korszerübb technológia

05 - jobb kapcsolat a vevőivel

06 - rugalmasság

\begin{tabular}{|c|}
\hline TÖBB VÁLASZ \\
LEHET! \\
\hline
\end{tabular}

07 - fizetési pontosság

08 - szállítási határidők betartása

09 - egyéb különbség, éspedig:

00 - semmiben sem különbözik

27. A vállalkozás első számú vezetője férfi vagy nő?

1 - férfi 2 - nő $X-$

EGYÉNI VÁLLALKOZÁSNÁL: MAGA A VÁLLALKOZÓ

\section{Mikor született a vállalkozás első számú vezetője?}

\begin{tabular}{|c|c|}
\hline & ÍRD BE, UTÁNA \\
\hline $\begin{array}{l}19 \\
99-\mathrm{NT} \quad \mathrm{X}-\end{array}$ & \\
\hline $\begin{array}{l}1-\text { kevesebb, mint } 25 \text { éves } \\
2-25-35 \text { éves } \\
3-36-45 \text { éves }\end{array}$ & $\begin{array}{c}4-46-55 \text { éves } \\
5-55 \text { évesnél } \\
\quad \text { idősebb } \\
X-\end{array}$ \\
\hline
\end{tabular}

29. Mi a vállalkozás első számú vezetőjének (egyéni vállalkozó, képviselő, ügyvezető, igazgató) iskolai végzettsége?

1 - föiskola, egyetem

2 - gimnáziumi, szakközépiskolai érettségi

$3-8$ általános + szakmunkásképző

4 - 8 általános

5 - kevesebb, mint 8 általános

$9-\mathrm{NT} \quad \mathrm{X}-$ 
30. A tulajdonosokon kívül a vállalkozás jelenleg hány embert foglalkoztat?

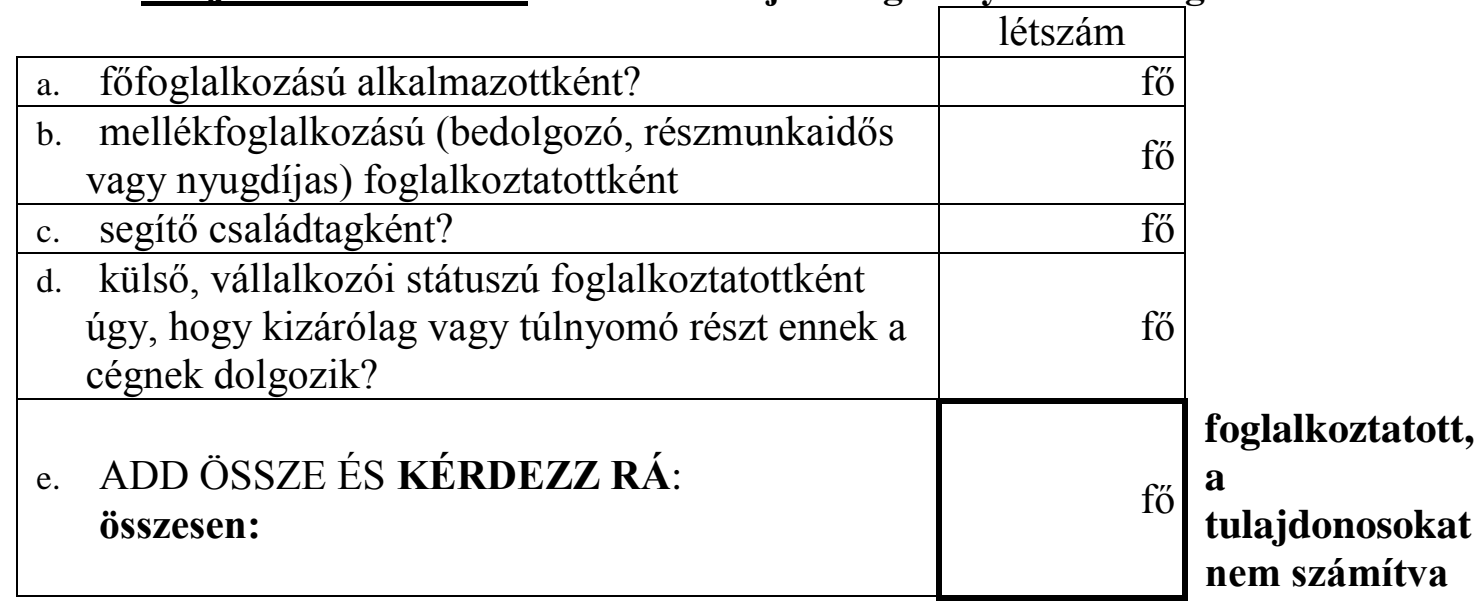

51. Egészében hogyan ítéli meg saját vállalkozásuk helyzetét jelenleg?

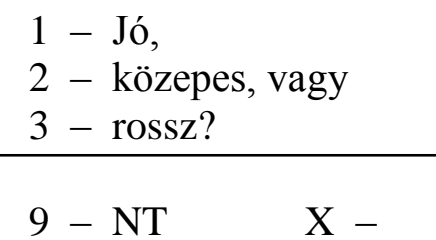




\section{2. függelék: „Versenyben a világgal 2009” kutatás felhasznált kérdései}

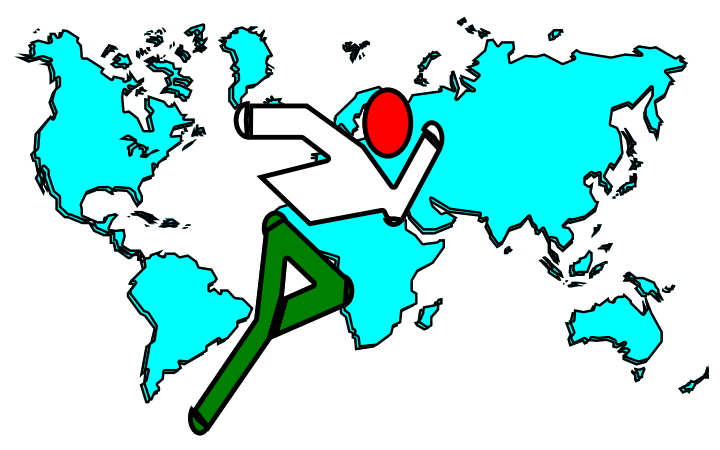

VERSENYBEN A VILÁGGAL 2009 - kutatási program

Budapesti Corvinus Egyetem

Vállalatgazdaságtan Intézet

VERSENYKÉPESSÉG KUTATÓ KÖZPONT

1093 Budapest, Fővám tér 8.

T: (1) $4825569 \mathrm{~F}:$ (1) 4825290

versenykepesseg@uni-corvinus.hu

www.versenykepesseg.uni-corvinus.hu

\section{VEZÉRIGAZGATÓ ÉS TÖRZSKAR}

ALAPINFORMÁCIÓK A VÁLLALATRÓL

A1. A vállalat 2008. évi átlagos állományi létszáma:

A8. A vállalat fö tevékenységi köre a

TEÁOR'08 első két számjegye alapján:

\section{A VÁLLALAT HELYZETE ÉS STRATÉGIÁJA}

V14.

a) Milyen színvonalat ért el a vállalat a tevékenységét jellemző alábbi területeken 2005-

2008 között a legerősebb versenytárshoz viszonyítva?

Amennyiben a vállalat több üzletágban müködik, kérjük válaszait a legjelentősebb üzletágra vonatkoztatva adja meg! Ha nincs hazai versenytársa, hasonlítsa cégét az iparág vezető külföldi vállalatainál jellemzőnek tekinthető színvonalhoz!

Az összevetés alapja: b) $\square$ vállalat egésze $\quad$ vagy $\square \quad$ domináns üzletág c) $\square$ belföldi versenytárs vagy $\square \quad$ a vezetö külföldi vállalatok

a) Költséghatékonyság

b) Piaci részesedés

c) Technológiai színvonal

d) Termékminőség

e) Termékválaszték szélessége

f) Versenyképes árak

g) Szállítás pontossága

h) Vevői igénykielégítés rugalmassága

i) Termelési rendszer rugalmassága

j) Logisztikai rendszer hatékonysága

k) Szállítási határidő rövidsége

1) Rugalmas reagálás a fogyasztói igények változására

m) Gyártási tevékenység színvonala

\begin{tabular}{ccc}
\multicolumn{3}{c}{ a) Teljesítményünk a legfőbb } \\
\multicolumn{2}{c}{ versenytárshoz képest: } \\
sokkal & lényegé & sokkal \\
gyengébb & ben & jobb \\
& azonos &
\end{tabular}


n) Stratégiai szövetségek a fö partnerekkel

o) Vállalati image

p) Elosztási csatornák szervezettsége

q) Hitelképesség

r) Kintlévőségek szintje

s) Fizetőképesség

t) Fogyasztói szolgáltatások színvonala

u) Lobbizás államigazgatási szerveknél

v) Államnak ill. költségvetési szerveknek történő értékesítés

w) Piaci változások előrejelzésének képessége

$\mathrm{x})$ Exportpiacokon való megjelenés

y) Etikus magatartás

z) Környezeti (ökológiai) tudatosság

aa) Megfelelő minőségü alapanyagok bevezetése

bb) Megbízható alapanyag ellátás

cc) Kapacitáskihasználás

dd) Alkalmazottak képzettsége

ee) Innovatív eladás-ösztönzési módszerek alkalmazása

ff) Színvonalas, jól felkészült vezetők

gg) Döntési/müködési módszerek korszerüsége

hh) $\mathrm{K}+\mathrm{F}$ ráfordítások szintje

ii) Új termékek piacra vitele

jj) Szervezeti struktúra hatékonysága

kk) Integrált vállalati információs rendszer

11) Vezetői információs rendszer színvonala

$\begin{array}{lllll}1 & 2 & 3 & 4 & 5 \\ 1 & 2 & 3 & 4 & 5 \\ 1 & 2 & 3 & 4 & 5 \\ 1 & 2 & 3 & 4 & 5 \\ 1 & 2 & 3 & 4 & 5 \\ 1 & 2 & 3 & 4 & 5 \\ 1 & 2 & 3 & 4 & 5 \\ 1 & 2 & 3 & 4 & 5 \\ 1 & 2 & 3 & 4 & 5 \\ & & & & \\ 1 & 2 & 3 & 4 & 5 \\ 1 & 2 & 3 & 4 & 5 \\ 1 & 2 & 3 & 4 & 5 \\ 1 & 2 & 3 & 4 & 5 \\ 1 & 2 & 3 & 4 & 5 \\ 1 & 2 & 3 & 4 & 5 \\ 1 & 2 & 3 & 4 & 5 \\ 1 & 2 & 3 & 4 & 5 \\ 1 & 2 & 3 & 4 & 5 \\ 1 & 2 & 3 & 4 & 5 \\ 1 & 2 & 3 & 4 & 5 \\ 1 & 2 & 3 & 4 & 5 \\ 1 & 2 & 3 & 4 & 5 \\ 1 & 2 & 3 & 4 & 5 \\ 1 & 2 & 3 & 4 & 5 \\ 1 & 2 & 3 & 4 & 5\end{array}$

V15. Az iparági átlaghoz viszonyítva értékelje vállalatának, illetve (több üzletág esetén) kiemelt üzletágának teljesítményét (belföldi összehasonlításban) a következők szerint:

1 - mélyen az iparági átlagszínvonal alatti

2 - az iparági átlagszínvonaltól némileg elmaradó

3 - az iparági átlagszínvonalhoz hasonló

4 - az iparági átlagszínvonalat némileg meghaladó

5 - az iparágban élenjáró színvonalat jelentő

a) Árbevétel-arányos nyereség

b) Tőkejövedelmezőség

c) Piaci részesedés (az árbevétel alapján)

d) Technológiai színvonal

e) Menedzsment

f) Termék/szolgáltatás minőség

g) Egyéb kiemelten kezelt „siker-kritérium”, nevezetesen:

$\begin{array}{lllll}1 & 2 & 3 & 4 & 5 \\ 1 & 2 & 3 & 4 & 5 \\ 1 & 2 & 3 & 4 & 5 \\ 1 & 2 & 3 & 4 & 5 \\ 1 & 2 & 3 & 4 & 5 \\ 1 & 2 & 3 & 4 & 5 \\ 1 & 2 & 3 & 4 & 5\end{array}$

V61. Hol helyezkedik el jelenleg a szervezeti hierarchiában az alábbi szakterületek felelős vezetője az Ön vállalatában? Lehetséges válaszok:

1 - vezérigazgató

2 - vezérigazgató helyettes

3 - ügyvezetô igazgató

4 - föosztályvezető
5 - osztályvezető

6 - csoportvezetö

7 - egyéb, éspedig

i) Készletgazdálkodás 
b) Kontrolling

c) Kutatásfejlesztés

d) Szervezetfejlesztés

e) Termelés

f) Értékesítés

g) Beszerzés

h) Logisztika j) Költséggazdálkodás

k) Emberi erőforrás gazdálkodás

1) Számvitel

m) Pénzügy

n) Bérgazdálkodás

o) Minőségbiztosítás

p) Információs menedzsment

q) Stratégiai tervezés

\section{SZERVEZETI KAPCSOLATOK}

M1. Jelölje meg az alábbi skálán, hogy az Ön vállalatának körülményei között a müködés egyes területeinek milyen tényleges súlya van az összvállalati müködés sikere szempontjából?

(1- csekély a jelentősége, 5- meghatározó tényező)
a) Felső vezetés
$\begin{array}{lllll}1 & 2 & 3 & 4 & 5\end{array}$
j) Készletgazdálkodás
$\begin{array}{lllll}1 & 2 & 3 & 4 & 5\end{array}$
b) Kereskedelem/Marketing
$\begin{array}{lllll}1 & 2 & 3 & 4 & 5\end{array}$
k) Költséggazdálkodás
$\begin{array}{llllll}1 & 2 & 3 & 4 & 5\end{array}$
c) Kontrolling
$\begin{array}{lllll}1 & 2 & 3 & 4 & 5\end{array}$
d) Kutatásfejlesztés
1) Emberi erőforrás menedzsment
e) Szervezetfejlesztés
$\begin{array}{lllll}1 & 2 & 3 & 4 & 5\end{array}$
m) Számvitel
$\begin{array}{lllll}1 & 2 & 3 & 4 & 5\end{array}$
$\begin{array}{lllll}1 & 2 & 3 & 4 & 5\end{array}$
f) Termelés
g) Értékesítés
$\begin{array}{lllll}1 & 2 & 3 & 4 & 5\end{array}$
n) Pénzügy
$\begin{array}{lllll}1 & 2 & 3 & 4 & 5\end{array}$
o) Bérgazdálkodás
p) Minőségbiztosítás
$\begin{array}{lllll}1 & 2 & 3 & 4 & 5 \\ 1 & 2 & 3 & 4 & 5\end{array}$
h) Beszerzés
q) Információmenedzsment
r) Stratégiai tervezés
$\begin{array}{lllll}1 & 2 & 3 & 4 & 5\end{array}$
$\begin{array}{lllll}1 & 2 & 3 & 4 & 5\end{array}$
$\begin{array}{lllll}1 & 2 & 3 & 4 & 5\end{array}$
$\begin{array}{lllll}1 & 2 & 3 & 4 & 5\end{array}$
i) Logisztika

\section{KERESKEDELEM, MARKETING}

\section{LOGISZTIKAI SZOLGÁLTATÁSOK}

K51. Jellemezze az elmúlt három évben a vállalatánál tapasztalt tendenciát! (1- jelentősen csökkent, 3 - változatlan maradt, 5 - jelentősen nőtt.)

a) alapanyagkészletek állománya.

12345

b) félkésztermékek állománya.

c) késztermékek és áruk állománya

d) szállítási költségek

e) készletezés költségei. ..12345

f) raktározás költségei. 12345

g) logisztikai rendszerhez kapcsolódó koordinációs költségek 12345

h) logisztikai rendszerhez kapcsolódó információs rendszer költségei.

i) logisztikai rendszerhez kapcsolódó humán erőforrás költségei

K52. Vállalata milyen logisztikai tevékenységek elvégzésére alkalmaz jelenleg külső logisztikai szolgáltató cégeket, s melyek kiszervezését tervezi az elkövetkezendő három évben?
a) Jelenleg
b) Tervezzük

a) szállítmányozás, fuvarozás.

b) raktározás.

c) készletgazdálkodás.

d) értéknövelt szolgáltatások nyújtása, pl. címkézés.

e) késleltetett összeszerelés.

f) ellátási lánc koordinációja.

g) call center müködtetése a vevői kapcsolatok kezelésére...

h) vámügyintézés. 
i) küldemény nyomon követése

j) menedzsment tanácsadás.

K54. Kérjük, értékelje a külső partnertől igénybe vett logisztikai szolgáltatások átlagos színvonalát! (1 nagyon alacsony színvonalú, 2 - még elfogadható, 3 - közepes, 4 - jó, 5 - kiemelkedően jó)

$\begin{array}{lllll}1 & 2 & 3 & 4 & 5\end{array}$

K55. Milyen jelentőséget kapnak vállalatánál az alábbi szempontok a külső logisztikai szolgáltatók teljesítményének értékelésekor? (Az alábbi skálán jelölje be az egyes tényezők fontosságát! 1 legkevésbé fontos, 5 - leginkább fontos)

a) költségcsökkentés

b) ígért szállitási határidő csökkentése.

123345

c) a szállítások pontosságának növelése.

$\begin{array}{lllll}1 & 2 & 3 & 4 & 5\end{array}$

d) készlet rendelkezésre állása

e) számlapontosság.

f) értéknövelt szolgáltatások nyújtása

123345

$\begin{array}{lllll}1 & 2 & 3 & 4 & 5\end{array}$

$\begin{array}{lllll}1 & 2 & 3 & 4 & 5\end{array}$

$\begin{array}{lllll}1 & 2 & 3 & 4 & 5\end{array}$

g) kapcsolattartó személy minősége

$\begin{array}{lllll}1 & 2 & 3 & 4 & 5\end{array}$

h) nyújtott információ minősége.

$\begin{array}{lllll}1 & 2 & 3 & 4 & 5\end{array}$

i) sérülések száma

j) egyéb, éspedig

$\begin{array}{lllll}1 & 2 & 3 & 4 & 5\end{array}$

$\begin{array}{lllll}1 & 2 & 3 & 4 & 5\end{array}$

K56. Amennyiben igénybe vesz külső partnertől logisztikai szolgáltatásokat, kérjük, nevezze meg az alkalmazás során felmerült problémákat! (Kérjük, ötös skálán értékelje az egyes problémák jelentőségét! 1 - elenyészően kicsi, 5 - kimagaslóan nagy problémákat okoz)

a) nem megfelelő információcsere.

b) nem megfelelő szintủ elkötelezettség saját vállalata részéröl

$\begin{array}{llllll}1 & 2 & 3 & 4 & 5\end{array}$

c) nem megfelelő szintủ elkötelezettség a szolgáltató cég részéről

$\begin{array}{llllll}1 & 2 & 3 & 4 & 5\end{array}$

d) nem megfelelő termékismeret a külső partnernél.

e) nem megfelelő a külső partner fogyasztóismerete.

$\begin{array}{lllll}1 & 2 & 3 & 4 & 5\end{array}$

$\begin{array}{lllll}1 & 2 & 3 & 4 & 5\end{array}$

f) nem körültekintő szerződéskötés

$\begin{array}{lllll}1 & 2 & 3 & 4 & 5\end{array}$

g) nem megfelelő a vállalat ellenőrzési mechanizmusa.

$\begin{array}{lllll}1 & 2 & 3 & 4 & 5\end{array}$

h) időhiány a kapcsolat és az együttműködés kialakítására

$\begin{array}{lllll}1 & 2 & 3 & 4 & 5\end{array}$

i) egyéb, éspedig

$\begin{array}{lllll}1 & 2 & 3 & 4 & 5\end{array}$ 


\section{3. függelék: A föszövegben nem szereplő ábrák, táblázatok}

38. táblázat: Egyszerre több logisztikai résztevékenységet kihelyező magyarországi KKV-k logisztikai funkció variációi

\begin{tabular}{|c|c|}
\hline Kiszervezett logisztikai tevékenység variációk & Aránya \\
\hline szállítás-szállítmányozás & $29,35 \%$ \\
\hline szállítás-raktározás & $7,07 \%$ \\
\hline szállítás-raktározás-szállítmányozás & $7,07 \%$ \\
\hline szállítmányozás-logisztikai-informatika & $4,35 \%$ \\
\hline szállítás-szállítmányozás-logisztikai informatika & $3,80 \%$ \\
\hline szállítás-raktározás-csomagolás-rendeléskezelés-logisztikai informatika & $3,80 \%$ \\
\hline szállítás-logisztikai informatika & $3,26 \%$ \\
\hline rendeléskezelés-logisztikai informatika & $3,26 \%$ \\
\hline raktározás-rendeléskezelés-logisztikai informatika & $3,26 \%$ \\
\hline $\begin{array}{l}\text { Szállítás-raktározás-csomagolás-szállítmányozás-rendeléskezelés-logisztikai } \\
\text { informatika }\end{array}$ & $2,72 \%$ \\
\hline szállítás-rendeléskezelés & $2,17 \%$ \\
\hline szállítmányozás-rendeléskezelés & $2,17 \%$ \\
\hline szállítás-csomagolás-szállítmányozás & $2,17 \%$ \\
\hline szállítás-raktározás-szállítmányozás-logisztikai informatika & $2,17 \%$ \\
\hline szállítás-raktározás-rendeléskezelés & $1,63 \%$ \\
\hline szállítás-szállítmányozás-rendeléskezelés & $1,63 \%$ \\
\hline szállítás-rendeléskezelés-logisztikai informatika & $1,63 \%$ \\
\hline raktározás-szállítmányozás-rendeléskezelés & $1,63 \%$ \\
\hline szállítás-raktározás-csomagolás-szállítmányozás & $1,63 \%$ \\
\hline szállítás-raktározás-rendeléskezelés-logisztikai informatika & $1,63 \%$ \\
\hline szállítás-szállítmányozás-rendeléskezelés-logisztikai informatika & $1,63 \%$ \\
\hline szállítás-csomagolás & $1,09 \%$ \\
\hline raktározás-logisztikai informatika & $1,09 \%$ \\
\hline szállítás-raktározás-csomagolás-rendeléskezelés & $1,09 \%$ \\
\hline szállítás-raktározás-csomagolás-logisztikai informatika & $1,09 \%$ \\
\hline szállítás-raktározás-szállítmányozás-rendeléskezelés & $1,09 \%$ \\
\hline raktározás-rendeléskezelés & $0,54 \%$ \\
\hline csomagolás-logisztikai informatika & $0,54 \%$ \\
\hline szállítás-raktározás-csomagolás & $0,54 \%$ \\
\hline szállítmányozás-rendeléskezelés-logisztikai informatika & $0,54 \%$ \\
\hline raktározás-csomagolás-szállítmányozás-logisztikai informatika & $0,54 \%$ \\
\hline csomagolás-szállítmányozás-rendeléskezelés-logisztikai informatika & $0,54 \%$ \\
\hline szállítás-raktározás-csomagolás-szállítmányozás-rendeléskezelés & $0,54 \%$ \\
\hline szállítás-raktározás-csomagolás-szállítmányozás-készletmenedzsment & $0,54 \%$ \\
\hline szállítás-raktározás-csomagolás-készletmenedzsment-logisztikai informatika & $0,54 \%$ \\
\hline szállítás-csomagolás-szállítmányozás-rendeléskezelés-logisztikai informatika & $0,54 \%$ \\
\hline $\begin{array}{l}\text { szállítás-csomagolás-szállítmányozás-készletmenedzsment-logisztikai } \\
\text { informatika }\end{array}$ & $0,54 \%$ \\
\hline $\begin{array}{l}\text { Szállítás-raktározás-csomagolás-szállítmányozás-rendeléskezelés- } \\
\text { készletmenedzsment-logisztikai informatika }\end{array}$ & $0,54 \%$ \\
\hline
\end{tabular}

Forrás: saját szerkesztés 
25. ábra: Logisztikai részköltségek és összköltség hisztogrammjai a normál eloszlással (H1 hipotézisek)
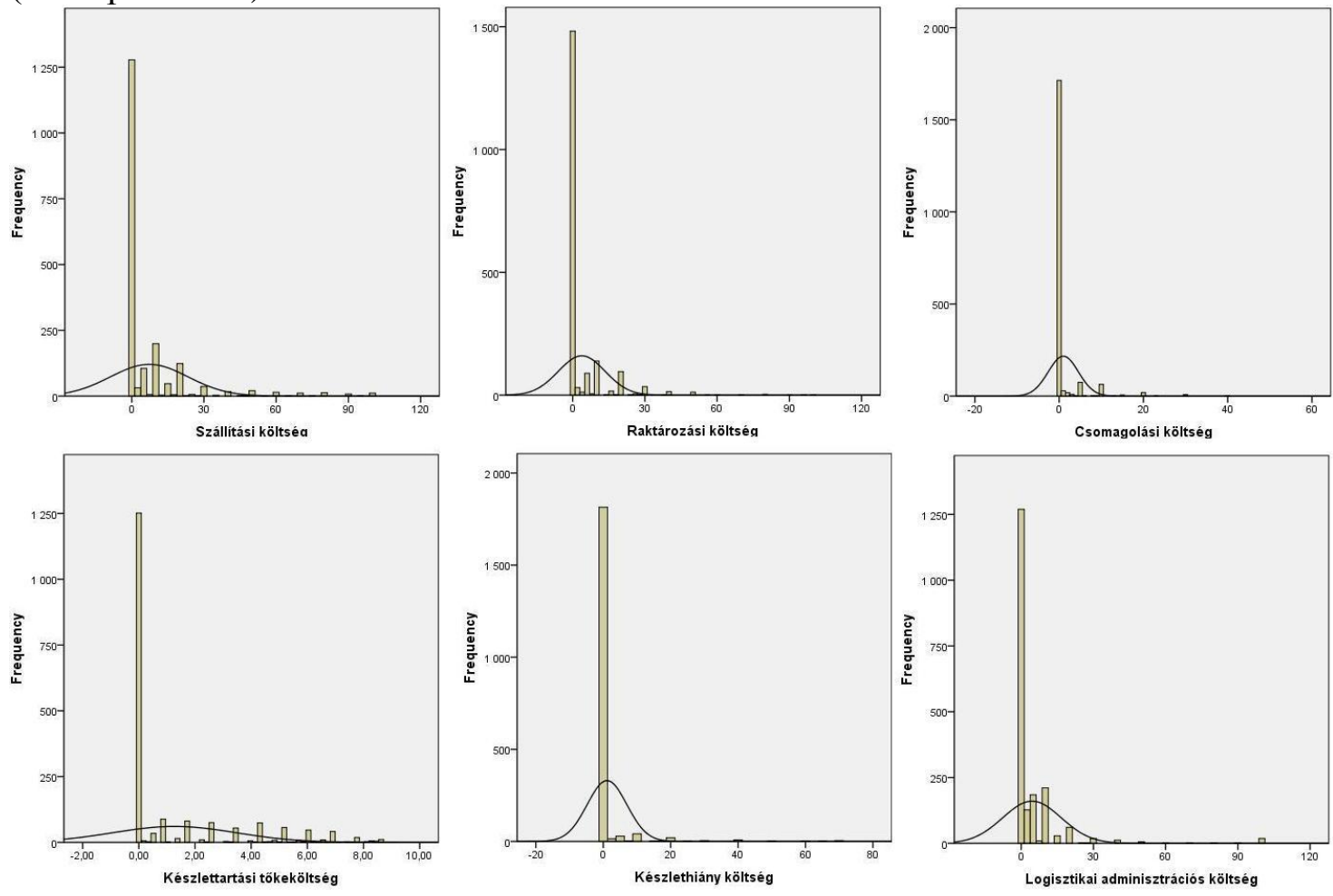

Forrás: saját szerkesztés

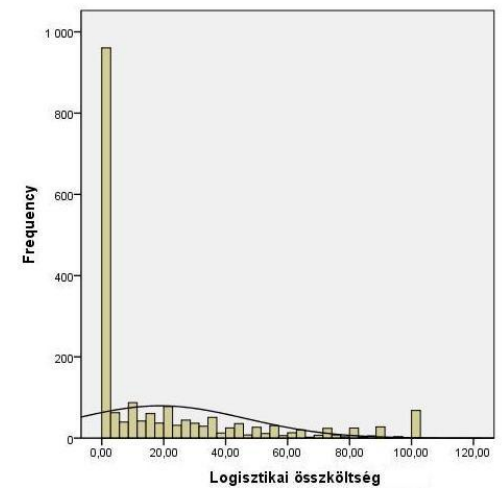


26. ábra: Logisztikai tevékenységkiszervezések hisztogrammjai a normál eloszlással (H1 hipotézisek)
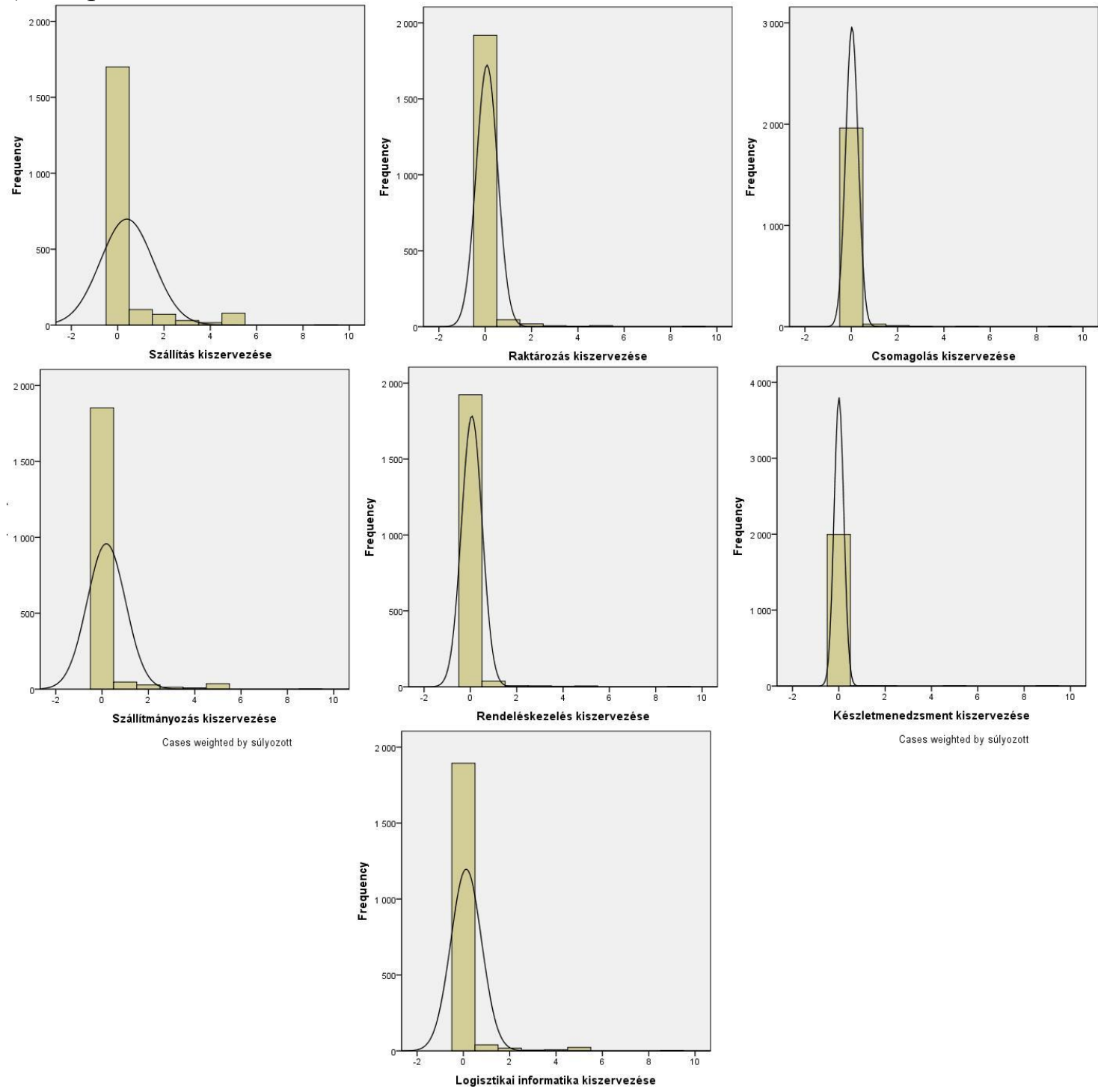

Forrás: saját szerkesztés

39. táblázat: Egyes logisztikai költségszintek és kiszervezési arányok összefüggései a mezőgazdasági, feldolgozóipari és kereskedelmi KKV körében

\begin{tabular}{|l|c|c|c|c|}
\hline & $\begin{array}{c}\text { Logisztikai } \\
\text { összköltség }\end{array}$ & $\begin{array}{c}\text { Szállítási } \\
\text { költség }\end{array}$ & $\begin{array}{c}\text { Raktározási } \\
\text { költség }\end{array}$ & $\begin{array}{c}\text { Csomagolási } \\
\text { költség }\end{array}$ \\
\hline Szállítás kiszervezése &, 302 &, 298 & - & - \\
\hline Raktározás kiszervezése &, 163 & - &, 205 & - \\
\hline Csomagolás kiszervezése &, 148 & - & - &, 203 \\
\hline Szállítmányozás kiszervezése &, 197 & - & - & - \\
\hline Rendeléskezelés kiszervezése &, 157 & - & - & - \\
\hline $\begin{array}{l}\text { Logisztikai informatika } \\
\text { kiszervezése }\end{array}$ &, 127 & - & - & - \\
\hline
\end{tabular}

Forrás: saját szerkesztés 
40. táblázat: Logisztikai költség és tevékenységkiszervezés elemek Levene tesztjeinek szignifikancia-szintjei (H1 hipotézisek)

\begin{tabular}{|c|c|c|c|c|c|c|c|c|c|c|c|c|c|}
\hline & 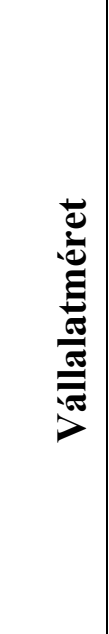 & 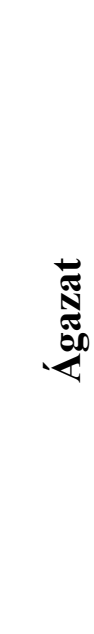 & 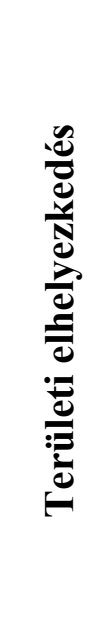 & 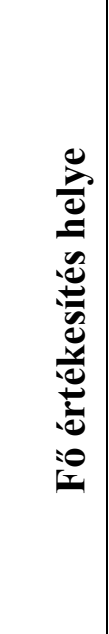 & 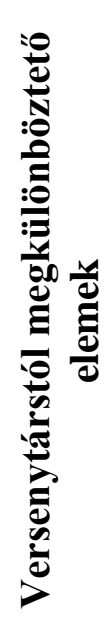 & 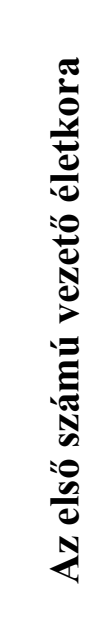 & 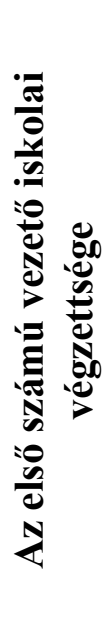 & $\frac{\pi}{2}$ & 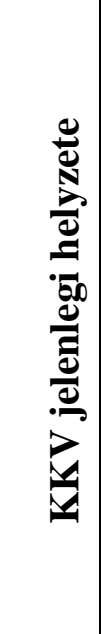 & 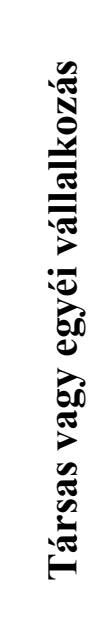 & 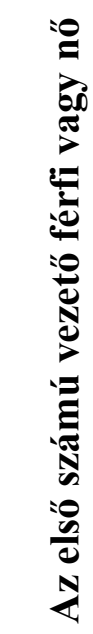 & 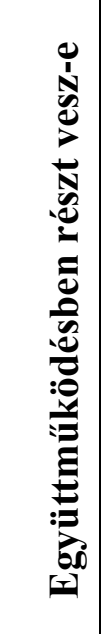 & 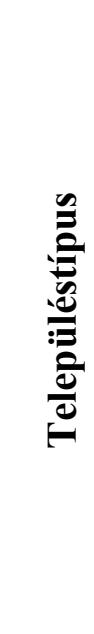 \\
\hline Szállítási költség & ,098 &, 000 & 000 &, 000 &, 000 &, 000 &, 000 & 290 & ,048 & ,849 &, 000 & ,361 & 000 \\
\hline Raktározási költség & ,000 & ,000 & ,000 & ,076 & ,000 & ,077 &, 005 & ,056 & ,002 & ,000 & ,005 & ,286 & ,006 \\
\hline Csomagolási költség & ,000 &, 000 & 027 &, 000 & ,000 &, 000 &, 000 &, 000 &, 114 &, 000 & 235 & 614 & ,777 \\
\hline Készlettartási tőkeköltség &, 000 & ,000 & ,000 & ,004 & ,060 & ,588 & ,000 & ,002 &, 000 & 000 & ,173 & 059 & ,006 \\
\hline Készlethiány költség &, 000 &, 000 & ,000 &, 008 &, 117 & , 136 &, 000 &, 035 &, 010 &, 550 &, 004 &, 000 & 000 \\
\hline Logisztikai adminisztrációs költség & ,867 & ,006 & ,003 & ,000 & ,121 & ,009 &, 015 & 609 & ,001 & ,001 & ,934 & ,013 & ,003 \\
\hline Logisztikai összköltség &, 000 &, 000 & 001 &, 000 &, 004 & 002 &, 117 & ,955 & ,003 & ,000 &, 000 & ,758 & 033 \\
\hline Szállítási kiszervezés &, 000 & ,000 & ,000 &, 000 &, 000 &, 006 &, 000 &, 002 & ,630 &, 000 &, 000 &, 000 & 083 \\
\hline Raktározás kiszervezés & ,000 & 000 & ,000 &, 000 &, 000 & 000 & ,000 & ,041 &, 000 & ,000 &, 000 & ,000 & ,000 \\
\hline Csomagolás kiszervezés &, 000 &, 000 & ,000 &, 000 &, 020 & ,003 &, 000 & 001 &, 000 &, 000 &, 010 &, 531 &, 000 \\
\hline Szállítmányozás kiszervezés & ,000 & ,000 & ,472 & ,000 & 000 & ,011 & ,000 & 011 & ,002 & ,000 &, 000 &, 000 & ,011 \\
\hline Rendeléskezelés kiszervezés & ,002 &, 000 &, 000 &, 000 &, 000 & ,783 &, 000 & 892 & 019 &, 000 &, 003 &, 000 &, 000 \\
\hline Készletmenedzsment kiszervezés &, 012 & ,029 & ,040 & 223 & ,363 & , 140 & ,001 &, 045 &, 000 & 593 & ,746 & ,676 & ,019 \\
\hline Logisztikai informatika kiszervezés &, 000 &, 000 & ,000 & ,000 &, 000 & ,106 &, 000 &, 000 & ,003 &, 000 & ,876 & ,038 & 000 \\
\hline
\end{tabular}

Forrás: saját szerkesztés 
41. táblázat: Logisztikai költségekre és tevékenységkiszervezésre ható tényezők éta értéke (mezőgazdaság, feldolgozóipar, kereskedelem) (H1 hipotézisek)

\begin{tabular}{|c|c|c|c|c|c|c|c|c|c|c|c|c|c|}
\hline & 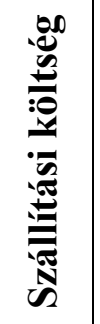 & 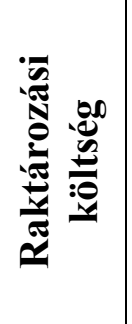 & 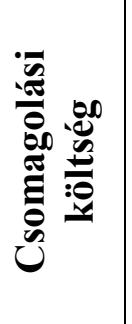 & 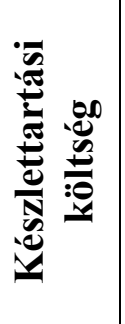 & 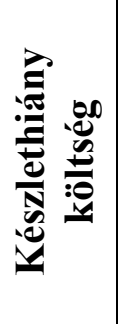 & 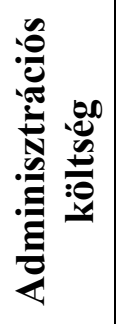 & 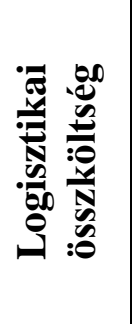 & 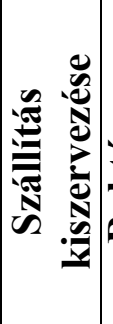 & 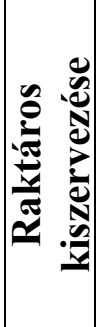 & 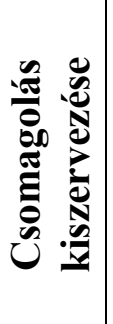 & 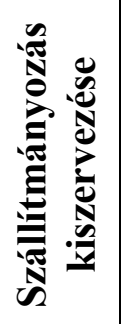 & 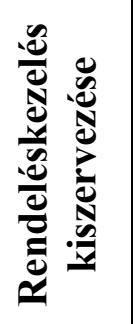 & 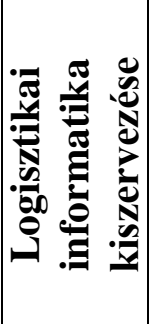 \\
\hline Vállalatméret &, 148 &, 242 &, 162 & ,115 & $*$ &, 178 &, 110 & ,156 &, 153 & $*$ &, 184 & $*$ &, 168 \\
\hline Ágazat & $*$ & $*$ &, 003 & ,149 & $*$ &, 104 & $*$ &, 109 & & $*$ & $*$ & $*$ & \\
\hline Területi elhelyezkedés &, 164 & $*$ & $*$ & $*$ &, 072 &, 044 &, 066 &, 108 &, 089 &, 064 & $*$ &, 103 & ,093 \\
\hline Fő értékesítés helye &, 117 & $*$ & $*$ &, 102 & ,086 & $*$ & $*$ &, 135 &, 213 & $*$ &, 152 &, 097 &, 113 \\
\hline Versenytárstól megkülönböztető elemek & $*$ & $*$ & $*$ & $*$ & $*$ & $*$ & $*$ & $*$ & $*$ & $*$ &, 108 & ,109 &, 133 \\
\hline Az első számú vezető életkora & $*$ & $*$ & $*$ & $*$ & $*$ &, 133 & $*$ & $*$ & $*$ & $*$ & $*$ & $*$ & $*$ \\
\hline Az első számú vezető iskolai végzettsége &, 060 & $*$ &, 006 &, 014 & $*$ & $*$ & $*$ &, 118 & $*$ & $*$ &, 166 & $*$ &, 154 \\
\hline KKV kora & $*$ & $*$ & $*$ & $*$ & $*$ & $*$ & $*$ & $*$ & $*$ & $*$ & $*$ & $*$ & * \\
\hline Településtípus & $*$ &, 044 & $*$ & $*$ &, 035 &, 024 & $*$ & $*$ &, $\mathbf{1 9 1}$ & ,126 & $*$ & ,196 & $*$ \\
\hline KKV jelenlegi helyzete & $*$ & $*$ & $*$ &, 006 & $*$ & $*$ & $*$ & $*$ &, 154 & $*$ & $*$ &, 077 & $*$ \\
\hline Társas vagy egyéni vállalkozás &, 139 & ,164 &, 080 & $*$ & $*$ & $*$ &, 097 &, 156 &, 089 & $*$ &, 096 &, 100 &, 148 \\
\hline Az első számú vezető férfi vagy nő &, 167 &, 096 & $*$ & $*$ & $*$ &, 101 & $*$ &, 120 & $*$ & $*$ &, 095 & $*$ & $*$ \\
\hline Együttmüködésben részt vesz-e &, 140 & $*$ & $*$ &, 081 & $*$ &, 095 &, 108 & ,198 & & $*$ &, 214 &, 090 &, 159 \\
\hline
\end{tabular}

Forrás: saját szerkesztés 
42. táblázat: Kiszervezés érveinek páronkénti asszociációját mutató Cramer V mértékek, mezőgazdaság, feldolgozóipar, kereskedelem (H3 hipotézisek)

\begin{tabular}{|c|c|c|c|c|c|c|c|c|c|c|c|c|c|c|c|c|c|}
\hline & $18 \mathrm{a}$ & $18 \mathrm{~b}$ & $18 \mathrm{c}$ & 18d & $18 \mathrm{e}$ & $18 f$ & $18 \mathrm{~g}$ & $18 \mathrm{~h}$ & 19a & 19b & $19 c$ & 19d & $19 \mathrm{e}$ & $19 f$ & $19 \mathrm{~g}$ & $19 \mathrm{~h}$ & $19 \mathbf{i}$ \\
\hline 18a: Földrajzi terjeszkedés & - & ,707 & ,686 & ,677 & ,686 & 665 &, 686 & ,679 &, 562 & ,578 & ,579 &, 538 &, 575 &, 543 & ,566 & ,588 &, 546 \\
\hline 18b: Minőségjavulás & & - & ,739 & ,764 & ,748 & 688 &, 713 &, 727 &, 569 & ,578 &, 580 &, 533 & ,587 &, 555 & ,563 & ,595 &, 558 \\
\hline 18c: Költségcsökkenés & & & - & ,738 & ,701 & 695 & ,674 & ,703 &, 566 & ,582 &, 574 &, 535 & ,579 & ,554 & ,566 & ,593 & ,549 \\
\hline 18d: Rugalmas kapacitás & & & & - & ,729 & ,736 & ,706 & ,700 &, 568 & ,576 & ,568 &, 544 & ,580 &, 555 & ,579 &, 591 & ,561 \\
\hline 18e: Külső szakértelem igénye & & & & & - & 680 &, 715 & ,716 &, 577 & ,587 & ,587 &, 554 &, 580 &, 565 &, 575 &, 597 &, 555 \\
\hline 18f: Alapvető képességfókusz & & & & & & - &, 670 & ,682 &, 567 &, 572 & ,579 &, 534 & ,574 &, 543 & ,576 &, 599 &, 555 \\
\hline 18g: Vásárló elvárja & & & & & & & - & ,743 &, 560 & ,574 & ,584 &, 542 & ,587 &, 559 & ,559 &, 578 &, 553 \\
\hline 18h: Beszállító elvárja & & & & & & & & - &, 572 & ,576 &, 586 &, 547 &, 585 &, 569 & ,563 &, 587 &, 565 \\
\hline 19a: Ellenőrzés elvesztése & & & & & & & & & - & ,765 & ,787 & ,698 & ,753 &, 631 & ,768 &, 778 & ,791 \\
\hline $\begin{array}{l}\text { 19b: A szállítás, raktározás, } \\
\text { csomagolás alapvető képesség }\end{array}$ & & & & & & & & & & - & ,767 & ,726 &, 770 & ,642 & ,724 &, 732 & ,715 \\
\hline 19c: Költségnövekedés & & & & & & & & & & & - & 692 & ,796 &, 650 & ,758 &, 749 & ,740 \\
\hline 19d: Jobb szakértelem & & & & & & & & & & & & - & ,698 &, 628 & ,668 &, 700 & ,705 \\
\hline $\begin{array}{l}\text { 19e: Szolgáltatási színvonal nem } \\
\text { javulna }\end{array}$ & & & & & & & & & & & & & - & ,651 & ,741 &, 754 & ,750 \\
\hline 19f: Nem tudja, miként vegye igénybe & & & & & & & & & & & & & & - & ,625 & 654 & 656 \\
\hline 19g: Rejtett költségek & & & & & & & & & & & & & & & - & ,783 &, 783 \\
\hline 19h: Függőség nő & & & & & & & & & & & & & & & & - & ,838 \\
\hline 19i: Értékelés és ellenőrzés nehézsége & & & & & & & & & & & & & & & & & \\
\hline
\end{tabular}

Forrás: saját szerkesztés 
27. ábra: Teljesítmény-klaszterek dendrogrammja (H5 hipotézisek)

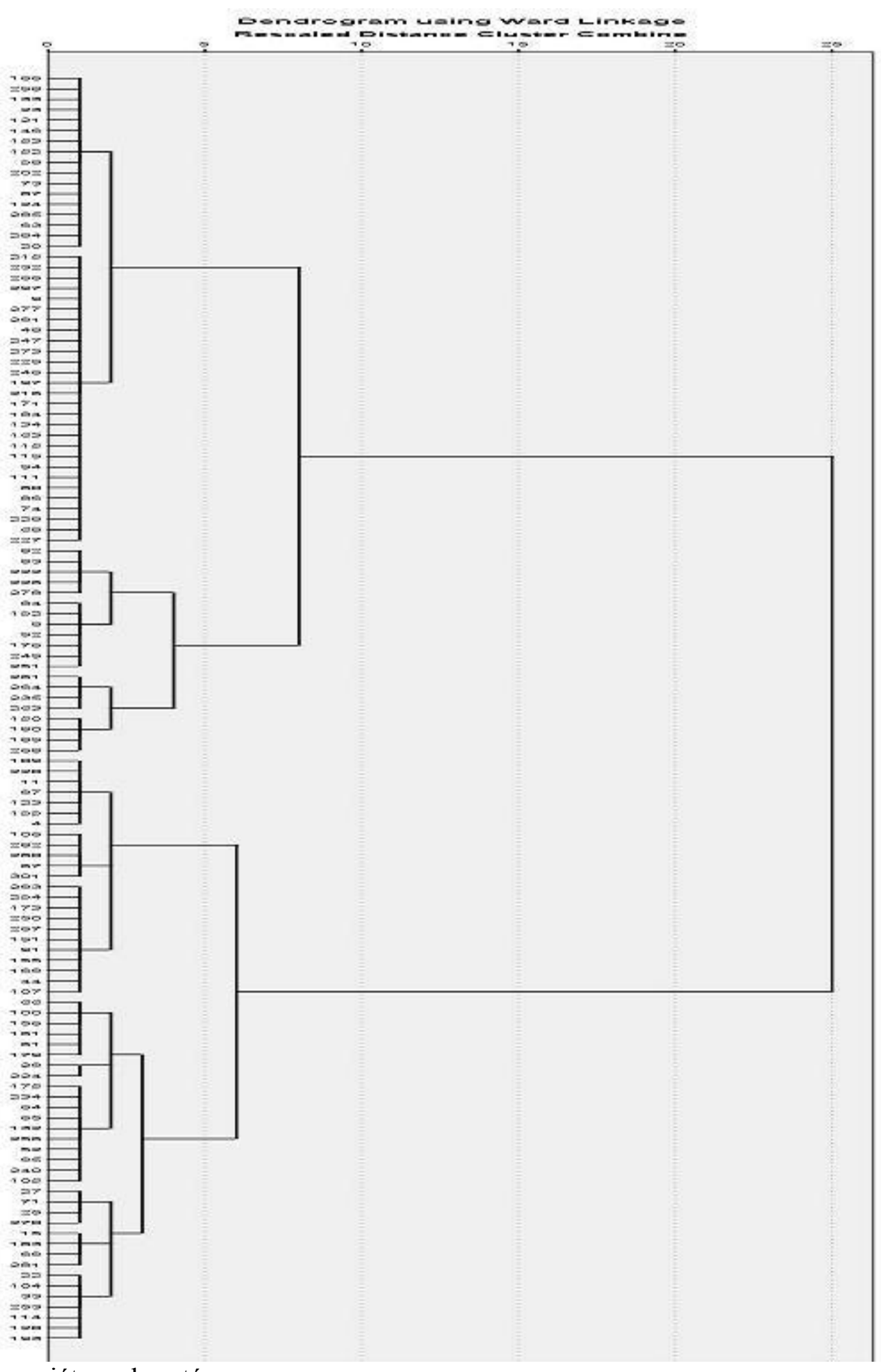

Forrás: saját szerkesztés 
43. táblázat: Mikrovállalkozások müködési területeinek súlya az összvállalati siker szempontjából és azok különbségei (H6 hipotézis)

\begin{tabular}{|c|c|c|c|c|c|c|c|c|c|c|}
\hline $\begin{array}{l}\text { MIKRO- } \\
\text { VÁLLALKOZÁS }\end{array}$ & $\begin{array}{l}\text { Vezérig. } \\
\text { (sorrend) }\end{array}$ & $\begin{array}{l}\text { Vezérig. } \\
\text { (átlag) }\end{array}$ & \begin{tabular}{|c} 
Keresk. \\
v. \\
(sorrend)
\end{tabular} & $\begin{array}{l}\text { Keresk. v. } \\
\text { (átlag) }\end{array}$ & $\begin{array}{c}\text { Pénzügyi } \\
\text { v. } \\
\text { (sorrend) }\end{array}$ & $\begin{array}{l}\text { Pénzügyi v. } \\
\text { (átlag) }\end{array}$ & $\begin{array}{l}\text { Term. v. } \\
\text { (sorrend) }\end{array}$ & $\begin{array}{l}\text { Term. v. } \\
\text { (átlag) }\end{array}$ & $\begin{array}{l}\text { Összesen } \\
\text { (sorrend) }\end{array}$ & $\begin{array}{c}\text { Összesen } \\
\text { (átlag) }\end{array}$ \\
\hline A: felső-vezetés & 1. & $4,31^{\text {defhijklmopq }}$ & 1. & $4,31^{\text {cdeijlpq }}$ & 3. & $4,24^{\mathrm{dijl}}$ & 2. & $4,23^{\text {deijpq }}$ & 1. & $4,22^{\text {cfijlq }}$ \\
\hline $\begin{array}{l}\text { B: kereskedelem/ } \\
\text { marketing }\end{array}$ & 2. & $4,26^{\text {cdehijlmnopq }}$ & 3. & $4,16^{\text {cdeijlpq }}$ & 5. & $4,06^{\mathrm{dg}}$ & 3. & $4,20^{\text {dehijpq }}$ & 2. & $4,22^{\text {cdefhijlq }}$ \\
\hline C: kontrolling & 9. & $3,77^{\text {bd }}$ & 16. & $3,32^{\text {acfghkmnor }}$ & 15 . & $3,69^{\mathrm{dgkn}}$ & 15. & $3,59^{\text {dglmn }}$ & 15. & $3,59^{\text {abdkno }}$ \\
\hline$D: K+F$ & 18. & $3,12^{\text {abcfgklnor }}$ & 18. & $3,06^{\text {abfghiklmnopqr }}$ & 18. & $3,25^{\text {abcfghijklmnopqr }}$ & 18. & $3,14^{\text {abcfgklmnor }}$ & 18. & $3,19^{\text {bcgo }}$ \\
\hline E: szervezet-fejlesztés & 17. & $3,45^{\mathrm{abk}}$ & 17. & $3,29^{\text {abfghkmor }}$ & 17. & $3,48^{\mathrm{gkn}}$ & 16. & $3,36^{\text {abgklmnor }}$ & 17. & $3,39^{\text {bno }}$ \\
\hline F: termelés & 8. & $3,79^{\mathrm{ad}}$ & 4. & $4,03^{\text {cdeij }}$ & 12. & $3,78^{\text {fgk }}$ & 11. & $3,76^{\mathrm{d}}$ & 12. & $3,74^{\text {abg }}$ \\
\hline G: értékesítés & 3. & $4,11^{\text {dhijq }}$ & 5. & $4,03^{\text {cdeij }}$ & 1. & $4,39^{\text {bcdefhijlmpqr }}$ & 1. & $4,27^{\text {cdehijpq }}$ & 3. & $4,15^{\text {dfijq }}$ \\
\hline H: beszerzés & 11. & $3,71^{\text {abgk }}$ & 6. & $4,00^{\text {cdeij }}$ & 7. & $4,00^{\mathrm{dgk}}$ & 10. & $3,77^{\text {bg }}$ & 8. & $3,89^{\mathrm{bkn}}$ \\
\hline I: logisztika & 16. & $3,47^{\mathrm{abgk}}$ & 15. & $3,56^{\text {abdfghk }}$ & 16. & $3,65^{\text {adgk }}$ & 13. & $3,69^{\mathrm{abg}}$ & 14. & $3,67^{\text {abgk }}$ \\
\hline J: készletgazdálkodás & 12. & $3,69^{\mathrm{abgk}}$ & 14. & $3,58^{\text {abfghkor }}$ & 8. & $3,94^{\text {adgk }}$ & 14. & $3,66^{\text {abgkn }}$ & 13. & $3,70^{\text {abn }}$ \\
\hline $\begin{array}{l}\text { K: költség- } \\
\text { gazdálkodás }\end{array}$ & 4. & $4,08^{\text {adehijmnpq }}$ & 2. & $4,16^{\text {cdeijlpq }}$ & 2. & $4,30^{\text {cdefhijlmqr }}$ & 6. & $4,00^{\text {dekq }}$ & 4. & $4,11^{\text {chilqr }}$ \\
\hline L: HR & 10. & $3,72^{\text {abdk }}$ & 11. & $3,68^{\mathrm{abdk}}$ & 10. & $3,88^{\text {adgk }}$ & 7. & $3,97^{\text {cdeq }}$ & 9. & $3,80^{\mathrm{abkn}}$ \\
\hline M: számvitel & 13. & $3,66^{\mathrm{abk}}$ & 10. & $3,84^{\text {cde }}$ & 9. & $3,91^{\mathrm{dgk}}$ & 5. & $4,04^{\text {cdeq }}$ & 6. & 3,96 \\
\hline N: pénzügy & 6. & $3,81^{\text {bd }}$ & 9. & $3,87^{\mathrm{cd}}$ & 4. & $4,15^{\text {cde }}$ & 4. & $4,10^{\text {cdejq }}$ & 5. & $4,03^{\text {cehjlq }}$ \\
\hline O: bérgazdálkodás & 7. & $3,80^{\text {abd }}$ & 7. & $4,00^{\text {cdejpq }}$ & 6. & $4,03^{\mathrm{d}}$ & 8. & $3,96^{\mathrm{deq}}$ & 7. & $3,94^{\text {cdeq }}$ \\
\hline P: minőség-biztosítás & 14. & $3,57^{\mathrm{abk}}$ & 12. & $3,61^{\text {abdko }}$ & 11. & $3,84^{\mathrm{dg}}$ & 12. & $3,71^{\text {abg }}$ & 10. & $3,78^{\mathrm{q}}$ \\
\hline $\begin{array}{l}\text { Q: információ- } \\
\text { menedzsment }\end{array}$ & 15. & $3,54^{\mathrm{abgk}}$ & 13. & $3,58^{\text {abdkor }}$ & 14. & $3,77^{\mathrm{dgk}}$ & 17. & $3,36^{\text {abgklmnor }}$ & 16. & $3,49^{\text {abgkmo }}$ \\
\hline R: stratégiai tervezés & 5. & $3,86^{\mathrm{d}}$ & 8. & $4,00^{\text {cdejq }}$ & 13. & $3,77^{\text {adgk }}$ & 9. & $3,86^{\text {deq }}$ & 11. & $3,75^{\mathrm{k}}$ \\
\hline
\end{tabular}

$\mathrm{a}, \mathrm{b}, \mathrm{c}, \ldots ., \mathrm{p}, \mathrm{q}, \mathrm{r}$ : a különbség/megváltozás 5\%-on szingnifikáns az adott tevékenységhez képest (pl. a: felső vezetés)

Forrás: saját szerkesztés 
44. táblázat: Kisvállalkozások müködési területeinek súlya az összvállalati siker szempontjából és azok különbségei (H6 hipotézis)

\begin{tabular}{|c|c|c|c|c|c|c|c|c|c|c|}
\hline $\begin{array}{l}\text { KIS- } \\
\text { VÁLLALKOZÁS }\end{array}$ & $\begin{array}{c}\text { Vezig. } \\
\text { (sorrend } \\
\text { ) }\end{array}$ & $\begin{array}{l}\text { Vezérig. } \\
\text { (átlag) }\end{array}$ & $\begin{array}{c}\text { Ker. v. } \\
\text { (sorrend } \\
\text { ) }\end{array}$ & $\begin{array}{l}\text { Keresk. v. } \\
\text { (átlag) }\end{array}$ & $\begin{array}{c}\text { Pénz. v. } \\
\text { (sorrend } \\
\text { ) }\end{array}$ & $\begin{array}{l}\text { Pénzügyi } \\
\text { v. (átlag) }\end{array}$ & \begin{tabular}{|c|}
$\begin{array}{c}\text { Term. v. } \\
\text { (sorrend } \\
\text { ) }\end{array}$ \\
\end{tabular} & $\begin{array}{l}\text { Term. v. } \\
\text { (átlag) }\end{array}$ & $\begin{array}{c}\text { Összesen } \\
\text { (sorrend } \\
\text { ) }\end{array}$ & $\begin{array}{l}\text { Összesen } \\
\text { (átlag) }\end{array}$ \\
\hline A: felső-vezetés & 1. & $4,71^{\mathrm{g}}$ & 2. & $4,43^{\text {bfgno }}$ & 2. & $4,54^{\mathrm{gn}}$ & 1. & $4,53^{\text {bgn }}$ & 1. & $4,56^{\mathrm{bg}}$ \\
\hline $\begin{array}{l}\text { B: kereskedelem/ } \\
\text { marketing }\end{array}$ & 3. & $4,26^{\mathrm{fmn}}$ & 4. & $4,28^{\text {afghkmnop }}$ & 6. & $4,12^{\text {fhjkmnop }}$ & 4. & $4,25^{\text {afghno }}$ & 3. & $4,42^{\text {agno }}$ \\
\hline C: kontrolling & 15. & $3,30^{\mathrm{ij} / \mathrm{pq}}$ & 16. & $3,43^{\text {eijq }}$ & 15. & $3,51^{\text {filpqr }}$ & 16. & $3,25^{\text {eljq }}$ & 16. & $3,55^{1 \mathrm{q}}$ \\
\hline D: K+F & 18. & 2,51 & 18. & $2,85^{\mathrm{e}}$ & 18. & $2,74^{\mathrm{e}}$ & 18. & 2,47 & 18. & 2,82 \\
\hline $\begin{array}{l}\text { E: szervezet- } \\
\text { fejlesztés }\end{array}$ & 17. & $2,89^{\mathrm{q}}$ & 17. & $3,13^{\mathrm{cd}}$ & 17. & $2,94^{\mathrm{d}}$ & 17. & $3,20^{\mathrm{cijqr}}$ & 17. & 3,21 \\
\hline F: termelés & 5. & $\begin{array}{l}4,15^{\text {bhkmno }} \\
\text { r }\end{array}$ & 6. & $\begin{array}{l}4,15^{\text {abghklmnopq }} \\
\mathrm{r}\end{array}$ & 11. & $\begin{array}{l}3,70^{\text {bcijklmopq }} \\
\mathrm{r}\end{array}$ & 7. & $\begin{array}{l}4,02^{\text {bhklmno }} \\
\text { p }\end{array}$ & 9. & $\begin{array}{l}4,03^{\text {abhijklmnopq }} \\
\mathrm{r}\end{array}$ \\
\hline G: értékesítés & 2. & $4,55^{\mathrm{a}}$ & 1. & $4,45^{\text {abfno }}$ & 1. & $4,63^{\mathrm{a}}$ & 2. & $4,47^{\mathrm{abn}}$ & 2. & $4,55^{\mathrm{ab}}$ \\
\hline H: beszerzés & 9. & $3,83^{\mathrm{fkmop}}$ & 10. & $3,98^{\text {bfijklmpqr }}$ & 4. & $4,27^{\text {bjkmno }}$ & 5. & $4,18^{\text {bfkmno }}$ & 6. & $4,13^{\mathrm{fkmop}}$ \\
\hline I: logisztika & 12. & $3,51^{\mathrm{cjkmq}}$ & 14. & $3,74^{\text {chjlqr }}$ & 14. & $3,55^{\mathrm{cflpqr}}$ & 13. & $3,59^{\text {cejlmpqr }}$ & 14. & $3,77^{\text {cfjlpqr }}$ \\
\hline $\begin{array}{l}\text { J: } \\
\text { készletgazdálkodás }\end{array}$ & 13. & $3,45^{\mathrm{cikmq}}$ & 15. & $3,71^{\text {chilqr }}$ & 9. & $\begin{array}{l}4,00^{\text {bfhklmnop }} \\
\text { q }\end{array}$ & 15. & $3,51^{\text {ceilqr }}$ & 13. & $3,80^{\text {filpqr }}$ \\
\hline $\begin{array}{l}\text { K: költség- } \\
\text { gazdálkodás }\end{array}$ & 8. & $3,91^{\text {fhijlnop }}$ & 8. & $4,14^{\mathrm{bfhlmnpr}}$ & 5. & $4,16^{\text {bfhjmnop }}$ & 8. & $3,98^{\text {fhlmnop }}$ & 7. & $4,13^{\text {fhmnop }}$ \\
\hline L: HR & 14. & $3,36^{\mathrm{ckmq}}$ & 11. & $3,94^{\text {thijkmpqr }}$ & 12. & $3,67^{\text {ctijpqr }}$ & 11. & $3,72^{\mathrm{fijkmpqr}}$ & 11. & $3,84^{\text {cfijpqr }}$ \\
\hline M: számvitel & 6. & $\begin{array}{l}3,94^{\text {bfhijlnp }} \\
\text { r }\end{array}$ & 7. & $4,14^{\text {bfhklnpqr }}$ & 7. & $4,08^{\text {bfhjkop }}$ & 9. & $3,92^{\text {fhiklpr }}$ & 8. & $4,12^{\text {fhkopr }}$ \\
\hline N: pénzügy & 4. & $4,18^{\mathrm{btkm}}$ & 5. & $4,24^{\text {abtgkmop }}$ & 3. & $4,29^{\text {abhjko }}$ & 3. & $4,25^{\text {abtghko }}$ & 4. & $4,32^{\text {bfko }}$ \\
\hline O: bérgazdálkodás & 7. & $3,93^{\text {thkr }}$ & 3. & $4,35^{\text {abfgn }}$ & 8. & $4,06^{\text {bfhjkmnp }}$ & 6. & $4,12^{\text {bfhkn }}$ & 5. & $4,23^{\text {bfhkmn }}$ \\
\hline $\begin{array}{l}\text { P: minőség- } \\
\text { biztosítás }\end{array}$ & 11. & $3,54^{\mathrm{chkmr}}$ & 9. & $4,10^{\text {bfhklmnr }}$ & 10. & $\begin{array}{l}3,83^{\text {bctijklmoq }} \\
\mathrm{r}\end{array}$ & 10. & $3,88^{\text {fiklmr }}$ & 10. & $3,94^{\text {fhijklmq }}$ \\
\hline $\begin{array}{l}\text { Q: információ- } \\
\text { menedzsment }\end{array}$ & 16. & $3,04^{\text {ceijl }}$ & 13. & $3,79^{\text {cfhijlmr }}$ & 13. & $3,59^{\text {cfijlpr }}$ & 14. & $3,56^{\text {ceijlr }}$ & 15 . & $3,72^{\text {cfijlpr }}$ \\
\hline $\begin{array}{l}\text { R: stratégiai } \\
\text { tervezés }\end{array}$ & 10. & $3,63^{\text {fmop }}$ & 12. & $3,94^{\text {fhijklmpq }}$ & 16. & $3,44^{\text {cfilpq }}$ & 12. & $3,62^{\text {eijlmpq }}$ & 12. & $3,83^{\mathrm{fijlmq}}$ \\
\hline
\end{tabular}


a, b, c, ..., p, q, r: 5\%-os szignifikancia-szinten egyezés az adott tevékenység átlagával (pl. a: felső vezetés) Forrás: saját szerkesztés

45. táblázat: Középvállalkozások müködési területeinek súlya az összvállalati siker szempontjából és azok különbségei (H6 hipotézis)

\begin{tabular}{|c|c|c|c|c|c|c|c|c|c|c|}
\hline $\begin{array}{l}\text { KÖZÉP- } \\
\text { VÁLLALKOZÁS }\end{array}$ & $\begin{array}{l}\text { Vezérig. } \\
\text { (sorrend) }\end{array}$ & $\begin{array}{l}\text { Vezérig. } \\
\text { (átlag) }\end{array}$ & $\begin{array}{c}\text { Keresk. } \\
\text { v. } \\
\text { (sorrend) }\end{array}$ & $\begin{array}{c}\text { Keresk. } \\
\text { v. } \\
\text { (átlag) }\end{array}$ & $\begin{array}{c}\text { Pénzügyi } \\
\text { v. } \\
\text { (sorrend) }\end{array}$ & $\begin{array}{l}\text { Pénzügyi } \\
\text { v. (átlag) }\end{array}$ & $\begin{array}{l}\text { Term. v. } \\
\text { (sorrend) }\end{array}$ & $\begin{array}{c}\text { Term. v. } \\
\text { (átlag) }\end{array}$ & $\begin{array}{l}\text { Összesen } \\
\text { (sorrend) }\end{array}$ & $\begin{array}{c}\text { Összesen } \\
\text { (átlag) }\end{array}$ \\
\hline a: felső-vezetés & 1. & 4,79 & 1. & 4,69 & 1 & 4,69 & 1. & $4,71^{\mathrm{g}}$ & 1. & 4,71 \\
\hline $\begin{array}{l}\text { b: kereskedelem/ } \\
\text { marketing }\end{array}$ & 4. & $4,30^{\mathrm{fkn}}$ & 5. & $4,21^{\mathrm{fhk}}$ & 7. & $4,03^{\text {fhjkmnop }}$ & 4. & $4,29^{\text {fhkn }}$ & 5. & $4,18^{\mathrm{fhkn}}$ \\
\hline c: kontrolling & 15. & $3,57^{1 \mathrm{q}}$ & 16. & $3,39^{\mathrm{q}}$ & 15. & $3,33^{19 r}$ & 15. & $3,55^{1 \mathrm{q}}$ & 15. & $3,43^{\mathrm{q}}$ \\
\hline d: $K+F$ & 18. & 2,69 & 18. & 2,75 & 18. & 2,41 & 18. & 2,74 & 18. & 2,59 \\
\hline e: szervezet-fejlesztés & 17. & 2,98 & 17. & 2,97 & 17. & 2,82 & 17. & 3,01 & 17. & 2,85 \\
\hline f: termelés & 5. & $4,16^{\text {bhkno }}$ & 3. & $4,29^{\mathrm{fghk}}$ & 10. & $3,90^{\text {bhjmop }}$ & 5. & $4,29^{\text {bhk }}$ & 4. & $4,22^{\text {bghk }}$ \\
\hline g: értékesítés & 2. & 4,45 & 2. & $4,40^{\mathrm{fk}}$ & 2. & $4,37^{\mathrm{kn}}$ & 2. & $4,56^{\mathrm{a}}$ & 2. & $4,44^{\mathrm{f}}$ \\
\hline h: beszerzés & 7. & $4,09^{\text {fno }}$ & 6. & $4,18^{\mathrm{bfkn}}$ & 5. & $4,11^{\text {bfkmno }}$ & 6. & $4,28^{\mathrm{bfk}}$ & 6. & $4,18^{\text {bfkno }}$ \\
\hline i: logisztika & 14. & $3,61^{\mathrm{cl}}$ & 13. & $3,69^{\mathrm{jlmpr}}$ & 13. & $3,53^{\mathrm{clr}}$ & 14. & $3,73^{\text {clmpr }}$ & 13. & $3,62^{\operatorname{lr}}$ \\
\hline $\begin{array}{l}\text { j: készlet- } \\
\text { gazdálkodás }\end{array}$ & 10. & $3,86^{\mathrm{mopr}}$ & 10. & $3,80^{\text {imnopr }}$ & 9. & $3,92^{\text {bfmop }}$ & 9. & $3,96^{1 \mathrm{mnopr}}$ & 10. & $3,91^{\text {mop }}$ \\
\hline $\begin{array}{l}\text { k: költség- } \\
\text { gazdálkodás }\end{array}$ & 3. & $4,30^{\mathrm{bfn}}$ & 4. & $4,28^{\text {bfgh }}$ & 3. & $4,27^{\text {bghn }}$ & 3. & $4,36^{\mathrm{bfh}}$ & 3. & $4,32^{\mathrm{bfh}}$ \\
\hline l: HR & 13. & $3,64^{\mathrm{ci}}$ & 14. & $3,62^{\text {ir }}$ & 12. & $3,57^{\mathrm{ir}}$ & 12. & $3,83^{\mathrm{ijmpr}}$ & 14. & $3,61^{\text {ir }}$ \\
\hline m: számvitel & 11. & $3,85^{\mathrm{jpr}}$ & 11. & $3,80^{\mathrm{ijopr}}$ & 8. & $4,01^{\text {bthjop }}$ & 11. & $3,90^{\mathrm{ij} \text { lopr }}$ & 11. & $3,90^{\mathrm{jop}}$ \\
\hline n: pénzügy & 6. & $4,11^{\text {bfhko }}$ & 7. & $3,99^{\text {hiop }}$ & 4. & $4,24^{\text {bghk }}$ & 7. & $4,07^{\text {bjop }}$ & 7. & $4,10^{\text {bho }}$ \\
\hline o: bérgazdálkodás & 8. & $3,98^{\text {fhjnpr }}$ & 8. & $3,94^{\mathrm{jmnpr}}$ & 6. & $4,07^{\text {bfhjm }}$ & 8. & $4,02^{\mathrm{jmnp}}$ & 8. & $4,03^{\text {hjmnp }}$ \\
\hline p: minőség-biztosítás & 9. & $3,87^{\mathrm{jmor}}$ & 9. & $3,93^{\mathrm{ijmnor}}$ & 11. & $3,88^{\mathrm{bfjm}}$ & 10. & $3,93^{\mathrm{ij} I m n o r}$ & 9. & $3,94^{\mathrm{jmo}}$ \\
\hline $\begin{array}{l}\text { q: információ- } \\
\text { menedzsment }\end{array}$ & 16. & $3,41^{\mathrm{c}}$ & 15. & $3,40^{\mathrm{c}}$ & 16. & $3,24^{\mathrm{c}}$ & 16. & $3,48^{\mathrm{c}}$ & 16. & $3,32^{\mathrm{c}}$ \\
\hline r: stratégiai tervezés & 12. & $3,84^{\text {jmop }}$ & 12. & $3,80^{\mathrm{ij} I \mathrm{mop}}$ & 14. & $3,45^{\mathrm{cil}}$ & 13. & $3,79^{\mathrm{ij} / \mathrm{mp}}$ & 12. & $3,71^{11}$ \\
\hline
\end{tabular}

$\mathrm{a}, \mathrm{b}, \mathrm{c}, \ldots ., \mathrm{p}, \mathrm{q}, \mathrm{r}:$ 5\%-os szingnifikancia-szinten egyezés az adott tevékenység átlagával (pl. a: felső vezetés)

Forrás: saját szerkesztés 
46. táblázat: Nagyvállalatok müködési területeinek súlya az összvállalati siker szempontjából és azok különbségei (H6 hipotézis)

\begin{tabular}{|c|c|c|c|c|c|c|c|c|c|c|}
\hline NAGYVÁLLALAT & $\begin{array}{l}\text { Vezérig. } \\
\text { (sorrend) }\end{array}$ & $\begin{array}{l}\text { Vezérig. } \\
\text { (átlag) }\end{array}$ & \begin{tabular}{|c|} 
Keresk. \\
v. \\
(sorrend)
\end{tabular} & $\begin{array}{l}\text { Keresk. v. } \\
\text { (átlag) }\end{array}$ & \begin{tabular}{|c|} 
Pénzügyi \\
v. \\
(sorrend)
\end{tabular} & $\begin{array}{c}\text { Pénzügyi v. } \\
\text { (átlag) }\end{array}$ & $\begin{array}{l}\text { Term. v. } \\
\text { (sorrend) }\end{array}$ & $\begin{array}{l}\text { Term. v. } \\
\text { (átlag) }\end{array}$ & $\begin{array}{l}\text { Összesen } \\
\text { (sorrend) }\end{array}$ & $\begin{array}{c}\text { Összesen } \\
\text { (átlag) }\end{array}$ \\
\hline a: felső-vezetés & 1. & $4,81^{\mathrm{g}}$ & 1. & 4,72 & 1. & $4,71^{\mathrm{fgk}}$ & 1. & $4,76^{\mathrm{k}}$ & 1. & $4,70^{\mathrm{g}}$ \\
\hline $\begin{array}{l}\text { b: kereskedelem/ } \\
\text { marketing }\end{array}$ & 5. & $4,08^{\text {cfiklnopqr }}$ & 4. & $4,09^{\text {cfghklmnopr }}$ & 9. & $4,09^{\text {cfhijlmnopqr }}$ & 6. & $4,05^{\text {cfhijlmnopqr }}$ & 6. & $3,98^{\text {cfhijklmnopqr }}$ \\
\hline c: kontrolling & 9. & $3,89^{\text {bhijlmnopqr }}$ & 10. & $3,75^{\text {bfhijlmnopqr }}$ & 12. & $3,85^{\text {bhijlmopqr }}$ & 12. & $3,78^{\text {bhijlmnopqr }}$ & 12. & $3,79^{\text {bhijlmnopqr }}$ \\
\hline d: $\mathbf{K}+\mathbf{F}$ & 18. & $2,86^{\mathrm{e}}$ & 18. & $2,87^{\mathrm{e}}$ & 18. & $2,76^{\mathrm{e}}$ & 18. & 3,00 & 18. & 2,84 \\
\hline e: szervezet-fejlesztés & 17. & $3,20^{\text {dhjm }}$ & 17. & $3,26^{\mathrm{dij}}$ & 17. & $3,15^{\mathrm{dj}}$ & 17. & $3,38^{\mathrm{ij}}$ & 17. & $3,15^{\mathrm{j}}$ \\
\hline f: termelés & 4. & $4,31^{\text {bgkpr }}$ & 5. & $4,06^{\text {bcghijklmnopr }}$ & 4. & $4,36^{\text {abgklnop }}$ & 4. & $4,22^{\text {bghklmnpqr }}$ & 4. & $4,27^{\text {bgknpr }}$ \\
\hline g: értékesítés & 2. & $4,43^{\mathrm{atk}}$ & 3. & $4,23^{\text {bfhkno }}$ & 2. & $4,56^{\text {atknp }}$ & 3. & $4,38^{\mathrm{fkp}}$ & 2. & $4,39^{\text {atknp }}$ \\
\hline h: beszerzés & 14. & $3,64^{\text {ceijlmnopqr }}$ & 7. & $3,91^{\text {bcfgijklmnopqr }}$ & 11. & $4,03^{\text {bcilmnopqr }}$ & 7. & $4,03^{\text {bctjlmnopqr }}$ & 10. & $3,88^{\text {bcilmnopqr }}$ \\
\hline i: logisztika & 12. & $3,71^{\text {bchlmnopqr }}$ & 15. & $3,61^{\text {cefhjlmnopq }}$ & 14. & $3,79^{\text {bchjlmoqr }}$ & 14. & $3,73^{\text {bcejlmnopqr }}$ & 15. & $3,65^{\text {bchjlmnoqr }}$ \\
\hline $\begin{array}{l}\text { j: készlet- } \\
\text { gazdálkodás }\end{array}$ & 16. & $3,23^{\text {cehm }}$ & 14. & $3,68^{\text {cfgilmnopqr }}$ & 16. & $3,56^{\text {bceiqr }}$ & 16. & $3,70^{\text {bcehilmnoqr }}$ & 16. & $3,47^{\text {bceilmnqr }}$ \\
\hline $\begin{array}{l}\text { k: költség- } \\
\text { gazdálkodás }\end{array}$ & 3. & $4,31^{\text {fgp }}$ & 2. & $4,25^{\mathrm{bfghn}}$ & 3. & $4,56^{\mathrm{afg}}$ & 2. & $4,57^{\mathrm{afg}}$ & 3. & $4,39^{\mathrm{bfg}}$ \\
\hline l: HR & 7. & $3,91^{\text {bchinopqr }}$ & 9. & $3,77^{\text {bcthijmnopqr }}$ & 10. & $4,09^{\text {bcthilnopqrr }}$ & 10. & $3,83^{\text {bcthijmnopqr }}$ & 9. & $3,90^{\text {bchijmnopqr }}$ \\
\hline m: számvitel & 15. & $3,57^{\text {cehijoqr }}$ & 13. & $3,71^{\text {bcfghijlopqr }}$ & 8. & $4,09^{\text {bchilopqr }}$ & 11. & $3,81^{\text {bcthijlnopqr }}$ & 11. & $3,79^{\text {bchijloqr }}$ \\
\hline n: pénzügy & 10. & $3,83^{\text {bchilopqr }}$ & 6. & $3,97^{\text {bctghijklopqr }}$ & 5. & $4,32^{\text {bfghlopqr }}$ & 8. & $3,95^{\text {bchijilmopqr }}$ & 7. & $3,95^{\text {bcfghijlopqr }}$ \\
\hline o: bérgazdálkodás & 13. & $3,71^{\text {bchilmnpqr }}$ & 8. & $3,84^{\text {bcfghijlmnpqr }}$ & 7. & $4,21^{\text {bcthilmnpq }}$ & 9. & $3,86^{\text {bchijlmnpqr }}$ & 8. & $3,92^{\text {bchilmnpqr }}$ \\
\hline p: minőség-biztosítás & 6. & $4,03^{\text {bcthiklnoqr }}$ & 11. & $3,72^{\text {bcfhijlmnoqr }}$ & 6. & $4,26^{\text {bctghlmno }}$ & 5. & $4,11^{\text {bcfghilmnoqr }}$ & 5. & $4,05^{\text {bctghlnor }}$ \\
\hline $\begin{array}{l}\text { q: információ- } \\
\text { menedzsment }\end{array}$ & 11. & $3,79^{\text {bchilmnopq }}$ & 16. & $3,53^{\text {chijlmnopr }}$ & 13. & $3,82^{\text {bchijlmnor }}$ & 13. & $3,78^{\text {bcfhijlmnopr }}$ & 14. & $3,70^{\text {bchijlmnor }}$ \\
\hline r: stratégiai tervezés & 8. & $3,91^{\text {bcthilmnopq }}$ & 12. & $3,72^{\text {bcthjlmopq }}$ & 15. & $3,74^{\text {bchijlmnr }}$ & 15. & $3,72^{\text {bcthijlmnopq }}$ & 13. & $3,72^{\text {bcthijlmnopq }}$ \\
\hline
\end{tabular}

a, b, c, ..., p, q, r: 5\%-os szingnifikancia-szinten egyezés az adott tevékenység átlagával (pl. a: felső vezetés)

Forrás: saját szerkesztés 


\section{4. függelék: A disszertációban használt rövidítések jegyzéke}

Rövidítés

3PL

BVL

EDI

ERP

DEM

HR

ISIC

INCOTERMS

JIT

KKV

KPI

MKV

NACE

NVOCC

ROA

RFID

SCOR

TEÁOR

V4
Idegen nyelvü elnevezés

Third-party logistics

Bundesvereinigung Logistik

Electronic Data Interchange

Enterprise Resources Planning

Deutsche Mark

Human resource

International Standard Industrial

Classification

International Commercial Terms

Just in time

Key performance indicator

Micro- and small enterprises

Nomenclature statistique des

activités économiques dans la

Communauté européenne

Non-vessel operating common

carrier

Return on assets

Radio Frequency Identification

Supply Chain Operation Reference

Tevékenységi körök egységes ágazati osztályozási rendszere Visegrádi négyek

Külső logisztikai szolgáltató

Német Logisztikai Szövetség

Elektronikus Adatcsere

Vállalati erőforrás tervezési

rendszer

Német márka

Emberi erőforrás

gazdasági tevékenységek

egységes nemzetközi ágazati

osztályozása

Nemzetközi Kereskedelmi

Feltételek

Éppen időben

Kis- és középvállalkozás

Kulcsmutatók

Mikro- és kisvállalkozás

Gazdasági tevékenységek

statisztikai osztályozása az

Európai Unióban

Fuvareszközt nem tulajdonló

hajóstársaság

Eszközarányos megtérülés

Rádiófrekvenciás azonosítás

Visegrad Four 


\section{Hivatkozások jegyzéke}

Aertsen, F. [1993]: Contracting-out the physical distribution function: a trade-off between asset specificity and performance measurement. International Journal of Physical Distribution \& Logistics Management, Vol. 23., No. 1., pp. 23-29.

Arbaugh, J.B. [2003]: Outsourcing intensity, strategy and growth in entrepreneurial firms. Journal of Enterprising Culture, Vol. 11., No. 2., pp. 89-110.

Arend, R.J. és Wisner, J.D. [2005]: Small business and supply chain management: is there a fit?, Journal of Business Venturing, Vol. 20., No. 3., pp. 403-436.

Arvis, J.F., Mustra, M.A., Ojala, L., Shephard, B. and Saslavsky, D. [2010]: Connecting to Compete 2010: Trade Logistics in the Global Economy. The World Bank, Washington.

Ashenbaum, B., Maltz, A. és Rabinovich, E. [2005]: Studies of trends in third-party logistics usage: what can we conclude? Transportation Journal, Vol. 44., No. 3., pp. 39-50.

Bagchi, P., és Virum H. [1998]: Logistical competencies of SMEs from Norway. Logistique et Management, Vol. 6., No. 2., pp. 9-111.

Babbie, E. [1999]: A társadalomtudományi kutatás gyakorlata. Balassi Kiadó, Budapest.

Bagchi, P.K., és Virum, H. [2000]: Logistics Competence in Small and Medium-Sized Enterprises: The Norwegian Experience. Supply Chain Forum, Vol. 1, No. 1., pp. 4655.

Bank, D., Bíró, P., Kopik, T., Losoncz, M., Molnár, L., Munkácsy, A., Szenczy, D. és Udvardi, A. [2010]: A magyarországi szállitási, szállitmányozási és logisztikai piac elemzése, valamint a versenyhelyzet és versenyképesség feltérképezése a szállitási szektorban és annak alágazataiban, különös tekintettel a vertikálisan integrált vállalatcsoportokra, nemzetközi kitekintéssel. GKI Gazdaságkutató Zrt., Budapest.

Bardi, E.J. és Tracey, M. [1991]: Transportation Outsourcing: A Survey of US Practices. International Journal of Physical Distribution and Logistics Management, Vol. 21., No. 3., pp. 15-21.

Beumer C., Furmans, K., Kilger, C. és Grosche, T. [2009]: Logistik im Mittelstand. Best Practices - Strategien für den Erfolg. Deutscher Verkehrs-Verlag, Hamburg.

Berr, U., Borchert, G. és Feldhahn, K.A. [1990]: Logistikkonzepte in kleinen und mittleren Unternehmen; in: Logistik im Unternehmen [1990], No. 6, pp. 30-32.

Bentzen, E., Christiansen, P.E., és Overo, J. [2000]: Outsourcing in purchasing departments in medium sized Danish manufacturers. Kézirat, Koppenhága.

Bordonaba-Juste, V. és Cambra-Fierro, J.J [2009]: Managing supply chain in the context of SMEs: a collaborative and customized partnership with the suppliers as the key for success. Supply Chain Management: An International Journal, Vol. 14., No. 5, pp. 393-402.

Bowersox, D.J., Closs, D.J., és Cooper, M.B. [2002]: Supply Chain Logistics Management. McGraw-Hill, New York.

Campos-Garcia, R.M., Garcia-Vidales, M.A. és Gonzales-Gomez, O. [2011]: Relationship between cost and logistic practices in small and medium enterprises: A case study of Queretaro, Mexico. African Journal of Business Management, Vol.5., No. 4., pp. 1245-1252.

Chao, H. és Shah, A.M. [2010]: Logistic Outsourcing Process in SMEs. Case Studies of Four Taiwanese SMEs. Linnaeus University, Kalmar.

Chikán A., Déri A., Kiss P., Némon Z., és Rónai P. [2007]: Nemzeti Logisztikai Stratégia. Kézirat, Budapest.

Chikán, A. [2008]: Vállalatgazdaságtan. Aula Kiadó, Budapest. 
Chikán, A., Czakó, E., és Zoltayné Paprika, Z. [2010]: Vállalati versenyképesség válsághelyzetben. Gyorsjelentés a 2009. évi felmérés eredményeiröl. Kézirat, Budapest.

Chikán, A. és Demeter, K. szerk. [2004]: Az értékteremtö folyamatok menedzsmentje. Aula Kiadó, Budapest.

Coase, R. H. [1937]: The Nature of The Firm, Economica, Vol. 4., No. 4., pp. 386-405.

Czakó, E. [2009]: A közszféra és a gazdaság versenyképessége: A hazai vállalatszerkezetböl fakadó következmények. Kézirat, Budapest.

Czakó, E. és Reszegi, L. szerk. [2010]: Nemzetközi vállalatgazdaságtan. Alinea Kiadó, Budapest.

Daugherty, P.J., Dtank, T.P. és Rogers, D.S. [1996]: Third party logistics service providers: purchaser's perceptions. International Journal of Purchasing and Materials Management, Vol. 32., No. 2., pp. 23-29.

Desaulniers, M. és Bigras Y. [1998]: Les alliances logistiques à l'exportation chez les PME manufacturières québécoises : une analyse de cas multiples. Kézirat, Montreál.

Deloitte [2010]: Áttekintö vizsgálat az államigazgatási szabályozásból fakadó vállalkozói adminisztrativ terhek teljes köréröl, illetve egyes fókuszterületekkel kapcsolatosan részletes felmérések elkészitése. Kézirat, Budapest.

Demeter, K., és Kolos, K. [2009]: Marketing, manufacturing and logistics: an empirical examination of their joint effort on company performance. International Journal of Manufacturing Technology and Management, Vol. 16., No. 3., pp. 215-233.

Dobler, D.W. [1965]: The challenge of proficiency in small company purchasing. Journal of Purchasing, Vol. 1., No. 1., pp. 53-61.

Donaldson, L. [1996]: For Positivist Organization Theory. Proving the Hard Core. SAGE Publications, London.

Donaldson, L. [2001]: The Contingency Theory of Organizations. SAGE Publications, London.

EIM Business \& Policy Research [2009]: European SMEs under Pressure. Annual Report on EU Small and Medium-sized Enterprises 2009. Kézirat, Brüsszel.

ELA, és A.T. Kearney [2009]: Excellence in Logistics 2008/2009: Global Supply Chain Management. Kézirat, Stuttgart.

Elger, T., Lundquist, K.J. és Olofolander, L. [2008]: Svensk makrologistik - Sammansättning och kostnadsutveckling 1997-2005. VINNOVA - Verket för Innovationssystem, Lund Universitet, Stockholm-Lund.

Ellegaard, C. [2006]: Small company purchasing: A research agenda. Journal of Purchasing \& Supply Chain Management, Vol. 12., pp. 272-283.

Ellegaard, C. [2009]: The purchasing orientation of small company owners. Journal of Business and Industrial Marketing, Vol. 24., No. 3., pp. 291-300.

Ellram, L.M. és Cooper, M.C. [1990]: Supply chain management, partnerships and the shipper-third party relationship. International Journal of Logistics Management, Vol. 30., No. 5., pp. 443-453.

European Commission [2011]: SBA Fact Sheet - Hungary - 2010/11. Kézirat, Brüsszel.

Evans, K.R., Feldman, H.D. és Foster, J. [1990]: Purchasing Motor Carrier Service: An Investigation of the Criteria Used by Small Manufacturing Firms. Journal of Small Business Management, Vol., 28, No. 1., pp. 39-47.

Fine, C.H. és Whitney, D.E. [1996]: Is the make-buy decision process a core competence? Working Paper, Mit Center for Technology, Policy and Industrial Development, Cambridge.

Finley, L. [1984]: Can your small company acquire resources as favorably as the large company? American Journal of Small Business, Vol. 9., No. 1., pp. 19-25. 
Fodor, Z. [2005]: Logisztikai információs rendszerek alkalmazásának hatása a kis- és középvállalkozások versenyképességére. Disszertáció, Budapest.

Frazelle, E. [2002]: Supply Chain Strategy - The Logistics of Supply Chain Management. McGraw-Hill, New York.

Futakfalvi, Gy. [2007]: A vevökiszolgálás értékelése egy speciális területen (a Biotest Hungária Kft. példáján). Szakdolgozat, Budapest.

Futala, T. és Mohor, J. [1995]: Weewls, R. - Wood, D.N., - Smith, A.V.: a szürke irodalom, a SIGLE és az EAGLE. A nemzetközi együttmüködés ígéretesen bővülő modellje. Tudományos és Müszaki Tájékoztatás, Vol. 42., No. 2., pp. 65-66.

Füstös, L., Kovács, E., Meszéna, Gy., és Simonné Mosolygó, N. [2004]: Alakfelismerés (Sokváltozós statisztikai módszerek). Új Mandátum Könyvkiadó, Budapest.

Gecse, G. [2009]: Logisztika az üzleti környezet felmérésben. Logisztikai Híradó, Vol. 19., No. 2., pp. 24-26.

Gelei, A. [2005]: Logisztikai versenyképesség a magyar vállalatok gyakorlatában. Mühelytanulmány, Budapest.

Gelei, A. [2007]: Beszállitó-típusok és azok alapvető kompetenciái a hazai autóipari ellátási láncban. Ph.D. értekezés, Budapest.

Gelei, A., és Nagy, J. [2010]: Logisztikai folyamatok informatikai támogatottsága Magyarországon - fókuszban a disztribúciós logisztika. Mühelytanulmány, Budapest.

Gelinas, R., Jacob, C. és Desaulniers, M. [2000]: La formation en logistique les enterprises manufacturiers quebecoises, IMRL 2000, Third International Meeting for Research in Logistics.

Gelinas, R. és Bigras, Y. [2004]: The Characteristics and Features of SMEs: Favorable or Unfavorable to Logistics Integration? Journal of Small Business Management, Vol. 42., No. 3., pp. 263-278.

Grando, A. és Belvedere, V. [2006]: District's manufacturing performances: A comparison among large, small-to-medium-sized and district enterprises. International Journal of Production Economics, 104, pp. 85-99.

Gritsch, M. [2001]: A logisztikai stratégia szerepe a vállalati versenyképességben: A Magyar vállalatok elött álló kihivások és lehetöségek. Phd disszertáció, Budapest.

Haan, J., Kisperksa-Moron, D., és Placzek E. [2007]: Logistics management and firm size; a survey among Polish small and medium enterprises. International Journal of Production Economics, Vol. 108, No. 1-2., pp. 119-126.

Halászné, S.E. [1998]: Logisztika, szolgáltatások, versenyképesség. Magyar Világ Kiadó, Budapest.

Halley, A., és Gulihon, A. [1997]: Logistics behaviour of small enterprises: performance, strategy and definition. International Journal of Physical Distribution \& Logistics Management, Vol. 27., No. 8. pp. 475-495.

Hamel, G. és Prahalad, C.K. [1990]: The Core Competence of Corporation. Harvard Business Review, Vol. 68, No. 3., pp. 79-91.

Harrington, L. [1995]: Small companies: find logistics tools. Transportation \& Distribution, Vol. 26, No. 3., pp. 56-60.

Heinrich, L.J. és Felhofer, E. [1985]: Empirische Befunde zur Gestaltung der LogistikOrganisation und Logistik-Informationssysteme in mittelständischen Industrieunternehmen. Journal für Betriebswirtschaft, Vol. 35., No. 2., pp. 62-78.

Heskett, J.L. [1977]: Logistics - essential to strategy. Harvard Business Review, Vol. 55., No. 6., pp. 85-96.

Hesse, M., és Rodrigue, J. [2004]: The transport geography of logistics and freight distribution. Journal of Transport Geography, Vol. 12, pp. 171-184. 
Holter, A.R., Grant, D.B., Ritchie, J.M. és Shaw, N. [2008]: A framework for purchasing transport services in small and medium size enterprises. International Journal of Physical Distribution \& Logistics Management, Vol. 38., No. 1., pp. 21-38.

Hong, J., Chin, A.T.H. és Liu, B. [2004a]: Logistics outsourcing by Manufacturers in China: A Survey of the Industry. Transportation Journal, Vol. 43., No. 1., pp. 17-25.

Hong, J., Chin, A.T.H. és Liu, B. [2004b]: Firm-Specific Characteristics and Logistics Outsourcing by Chinese Manufacturers. Asia Pacific Journal of Marketing and Logistics, Vol. 16., No. 3., pp. 23-36.

Hovi, I.B. és Hansen, W. [2010]: Logistikkostnader $i$ norske vareleverende bedrifter. Nøkkeltall og internasjonale sammenlikninger. TØI Transportøkonomisk institutt Stiftelsen Norsk senter for samferselsforskning, Oslo.

Hudson, R.L., és McArthur, A.W. [1994]: Contracting strategies in entrepreneurial and established firms. Entrepreneurship Theory and Practice, Vol. 18., No. 3., pp. 43-59.

Hutchinson, K., Fleck, E. és Lloyd-Reason, L. [2009]: An investigation into the initial barriers to internationalization. Evidence from small UK retailers. Journal of Small Business and Enterprise Development, Vol. 16, No. 4, pp. 544-568.

IMD [2008]: World Competitiveness Yearbook 2008. Kézirat, Lausanne.

Ivanaj, V., és Masson Franzil, Y. [2006]: Outsourcing logistics activities: a transaction cost economics perspective. XVth Conference International de Management Stratégique, Annecy/Genf.

Kállay, L. és Imreh, Sz. [2004]: A kis- és középvállalkozás-fejlesztés gazdaságtana. Aula Kiadó, Budapest.

Kállay, L., Kissné, K.E., Kőhegyi. K., és Maszlag. L. [2009]: Kis- és középvállalkozások helyzete 2008. Nemzeti Fejlesztési és Gazdasági Minisztérium, Budapest.

Kállay, L., Kissné, K.E., Kőhegyi, K., és Maszlag, L. [2010]: Kis- és középvállalkozások helyzete 2009. Kézirat, Budapest. Megjelenés alatt.

Kasouf, C.J., és Celuch, K.G. [1997]: Interfirm Relationship in the Supply Chain: The Small Supplier's View. Industrial Marketing Management, Vol. 26., No. 6., pp. 475-486.

Kent, J.L. és Flint, D.J. [1997]: Perspectives on the Evolution of Logistics Thought. Journal of Business Logistics, Vol. 18., No. 2., pp. 15-29.

Ketskeméty, L., Izsó, L. és Könyves Tóth, E. [2011]: Bevezetés az SPSS Statistics programrendszerbe. Módszertani útmutató és feladatgyüjtemény statisztikai elemzésekhez. Artéria Stúdió Kft, Budapest.

Kerpeszki, I. [2001]: A kis- és közepes vállalkozások helye az ellátási láncban. In: MLE [2001]: Logisztikai Évkönyv. Magyar Logisztikai Egyesület, Budapest.

Kieser A. [1995]: Szervezetelméletek. Aula Kiadó, Budapest

King, D. szerk. [2010]: The 6th Annual State of Logistics Survey for South Africa 2009. CSIR, Pretoria.

Klaus, P. [2009]: Logistics research: a 50 years' march of ideas. Logistics Research, Vol. 1., No. 1., pp. 53-65.

Klaus, P. [2008]: Märkte und Marktentwicklungen der weltweiten Logistikdienstleistungswirtschaft. In: Baumgarten, H. szerk. [2008]: Das Beste in der Logistik. Innovationen, Strategien, Umsetzungen. Springer, Berlin, pp. 13-19.

Kotabe, M. és Mol, M.J. [2009]: Outsourcing and financial performance: a negative curvilinear effect. Journal of Purchasing and Supply Management, Vol. 15., No. 4., pp. 205-213.

Krugman, P. [1991]: Increasing Returns and Economic Geography. The Journal of Political Economy, Vol. 99, No. 3., pp. 483-499.

Kummer, S. [1992]: Logistik im Mittelstand. Stand und Kontextfaktoren der Logistik im mittelständischen Unternehmen. Schäffer-Poeschel Verlag, Stuttgart. 
Kummer, S. [1995]: Logistik für den Mittelstand. Leitfaden für das Logistikmanagement in mittelständischen Unternehmen. Hussverlag, München.

Langley, C.J. és Capgemini [2009]: The State of Logistics Outsourcing. 2009 third party logistics. Kézirat, Atlanta.

Lea, R., Hagen, J.M., Lindjord, J.E., Barlaup T.H. és Boe, K. [1996]: Eksportlogistikk I sma og mellomstore bedrifter. Kézirat, Oslo.

Lewis, H.T., Culliton, W., és Steele, J.D. [1956]: The Role of Air Freight in Physical Distribution. Harvard Business School, Boston.

Love, T.J., és Gilmour, P. [1976]: A Logistics Review for the Small Company. International Journal of Logistics \& Production Management, Vol. 6., No. 6., pp. 295-319.

Lynaigh, P.M., és Poist, R.F. [1984]: Logistics Management: A Frontier Area for Small Business. American Journal of Small Business, Vol. 8, No. 3., pp. 9-16.

Malhotra, N. K. [2002]: Marketingkutatás. KJK-Kerszöv Kiadó, Budapest.

Maltz, A.B. [1994]: Outsourcing the warehousing function: economic and strategic considerations. Logistics and Transportation Review, Vol. 30., No. 3., pp. 245-265.

Maltz, A.B. és Ellram, L.M. [1997]: Total cost of relationship: an analytical framework for the logistics outsourcing decisions. Journal of Business Logistics, Vol. 18., No. 1., pp. 45-66.

Matyusz, Zs. [2010]: A 2009-es versenyképesség kutatás vállalati mintájának alapjellemzöi és reprezentativitása. Kézirat, Budapest.

McIvor R. [2000]: A practical framework for understanding the outsourcing process. Supply Chain Management: An International Journal, Vol. 5., No. 1., pp. 22-36.

Morrissey, B., és Pittaway, L. [2004]: A study of procurement behaviour in small firms. Journal of Small Business and Enterprise Development, Vol. 11., No. 2, pp. 254-262.

Murphy, P.R., és Daley, J.M. [1997]: Investigating Selection Criteria for International Freight Forwarders. Transportation Journal, Fall 1997, pp. 29-36.

Murphy, P.R., Daley, J.M. és Knemeyer, A.M. [1999]: Comparing Logistics Management in Small and Large Firms: An Explanatory Study. Transportation Journal, Vol. 38., No. 4, pp. 18-25.

Murphy, P.R., Daley, J.M. és Dalenberg, D.R. [1995]: Logistics Practices of Smaller Businesses Currently Engaged in International Trade. Defense Transportation Journal, June 1995, pp. 10-17.

Nabhani, F., és Shokri, A. [2009]: Reducing the delivery lead time in a food distribution SME through the implementation of six sigma methodology. Journal of Manufacturing Technology Management, Vol. 20., No. 7., pp. 957-974.

Nagy, I. [2008]: Outsourcing döntés megalapozása. Szállitási tevékenység minőségének vizsgálata a Nyírség-Hasso Kft-nél. Szakdolgozat, Budapest.

Nagy, J. [2006]: A logisztikai funkció szerepe a vállalati müködés sikerében. Mühelytanulmány, Budapest.

Naula, T., Ojala, L. és Solakivi, T. [2006]: Finland - State of Logistics 2006. Publications of the Ministry of Transport and Communications Finland 45/2006, Edita Publishing, Helsinki.

Némethné, G.A. [2006]: Statisztikai módszerek alkalmazásának lehetöségei a kis- és középvállalkozások versenyképességének elemzésében. Kézirat, Győr.

Nemzeti Adó- és Vámhivatal [2011]: GYORSJELENTÉS a 2011. május 31-én társasági adóbevallásra kötelezett vállalkozások adataiból. Kézirat, Budapest.

NFGM [2009]: A gazdasági válság és a mikro- és kisvállalkozások. Kézirat, Budapest.

Ojala, L. és Solakivi T. [2009]: International Logistics Surveys. CSCMP's Annual Global Conference, Chicago. 
Ojala, L., Solaviki T., Hälinen, H.M., Lorentz, H., and Hoffmann, T.M. [2007]: State of Logistics in the Baltic Sea Region. Turku School of Economics, Turku.

Olavarrieta, S. és Ellinger, A.E. [1997]: Resource-based Theory and Strategic Logistics Research. International Journal of Physical Distribution \& Logistics Management, Vol. 27., No. 9/10, pp. 559-587.

Orfanos, V., Mylonakis, J. és Evripiotis, M. [2010]: An Evaluation of Logistics Determinants, Business Relationships and Firms Characteristics of the Greek Small and Medium Enterprises. International Journal of Marketing Studies, Vol. 2., No. 2., pp. 21-33.

Otto, A. [2002]: Management und Controlling von Supply Chains. Ein Modell auf der Basis der Netzwerktheorie. Deutscher Universitats-Verlag, Wiesbaden

Overby, J, W, és Servais, P, [2005]: Small and medium-sized firms' import behaviour: The case of Danish industrial purchasers. Industrial Marketing Management, Vol. 34., No. 1, pp. 71-83.

Paik, S.K., Bagchi, P.K., Skjøtt-Larsen, T. és Adams, J. [2009]: Purchasing Development in Small and Medium-Sized Enterprises (SMEs). Supply Chain Forum - An International Journal, Vol. 10., No. 1., pp. 92-107.

Papanek, G. szerk. [2009]: A mikro-, kis és közepes vállalatok növekedésének feltételei. Kézirat, Budapest.

Pearson, J.N., és Semeijn, J. [1999]: Service Priorities in Small and Large Firms Engaged in International Logistics. International Journal of Physical Distribution and Logistics Management, Vol. 29., No. 3, pp. 181-192.

Pezzotta, G., Cavalieri, S., Gaiardelli, P., Legnani, E., Palm, D., Kimmich, J., Morawetz, C., Czinege, I., Ilie-Zudor, E., Pfeiffer, A és Kóbor, I. [2006]: Improving Logistics Performance of SMEs in the Automotive Sector. Final Report. Kézirat, Bergamo.

Pfohl, H.C., Hofmann, E. és Elbert, R [2003]: Financial supply chain management. Neue Herausforderungen für die Finanz- und Logistikwelt. Logistics Management, Vol. 5., No. 4., pp. 10-26.

Pressey, A.D., Winklhofer, H.M., és Tzokas, N.X. [2009]: Purchasing practices in small- to medium-sized enterprises: An examination of strategic purchasing adoption, supplier evaluation and supplier capabilities. Journal of Purchasing \& Supply Management, Vol. 15., No. 4., pp. 214-226.

Presutti, W.D. [1988]: Purchasing Management Practices of Small Manufacturers, Journal of Purchasing and Materials Management, Vol. 24., No. 1., pp. 26-31.

Razzaque, M.A. és Sheng, C.C. [1998] : Outsourcing of logistics functions : a literature survey. International Journal of Physical Distribution \& Logistics Management. Vol 28., No. 2., pp. 89-107.

Roy, J., Bigras, Y., Filiatrault P. és Martel, A. [2002]: Analyse des besoins de formation en logistique au Québec. Rapport remis à l'Institut de formation en gestion du transport et de la logistique, Centre de recherche en gestion (CRG), UQAM.

Qingxuan, G., Shuping, Y., Mingxi, Z. és Zhang, Y. [2008]: A study of the strategy for logistics cost control in small and medium-sized steel enterprises. Journal of Advanced Manufacturing Systems, Vol. 7., No. 2. pp. 287-290.

Quayle, M. [2000]: Supplier development for UK small and medium-sized enterprises. Journal of Applied Management Studies, Vol. 9., No. 1., pp. 117-133.

Quayle, M. [2002a]: E-commerce: the challenge for UK SMEs in the twenty-first century. International Journal of Operations and Production, Vol. 22., No. 10., pp. 1148-1161.

Quayle, M. [2002b]: Purchasing in small firms. European Journal of Purchasing and Supply Chain Management, Vol. 8., No 3., pp. 151-159. 
Quayle, M. [2002c]: Supplier development and supply chain management in small and medium size enterprises. International Journal of Technology Management, Vol. 23., No. 1-3., pp. 172-188.

Rodrigues, A.M, Bowersox, D.J., és Calantone, R.J. [2005]: Estimation of Global and National Logistics Expenditures: 2002 Data Update. Journal of Business Logistics, Vol. 26., No. 2., pp. 1-16.

Sajtos, L. és Mitev, A. [2007]: SPSS kutatási és adatelemzési kézikönyv. Alinea Kiadó, Budapest.

Salamonné, H.A. [2007]: Stratégia és stratégiaalkotás a magyarországi kis- és középvállalkozások gyakorlatában. Competitio, Vol. 6, No. 1., pp. 19-31.

Samuelson, P. [1952]: Spatial price equilibrium and linear programming. American Economic Review, Vol. 42, pp. 283-303.

SBA [2010]: Table of Small Business Size Standards Matched to North American Industry Classification System Codes. Kézirat, Washington.

Schramm-Klein, H. és Morschett, D. [2006]: The relationship between marketing performance, logistics performance and company performance for retail companies. International review of Retail, Distribution and Consumer Research, Vol. 16, No. 2., pp. 277-296

Scully, J.I., és Fawcett, S.E. [1994]: International procurement strategies: challenges and opportunities for the small firm. Production and Inventory Management Journal, Vol. 35., No. 2., pp. 39-46.

Sebestyén, L. [2003]: A legnagyobb árbevételü hazai vállalatok logisztikai müködése. (A "Figyelö TOP 200" listájában szereplö vállalatok körében végzett felmérés eredményei). EU Working papers 1/2003, pp. 52-68.

Selviaridis, K. és Spring, M. [2007]: Third party logistics: a literature review and research agenda. The International Journal of Logistics Management, Vol. 18., No. 1., pp. 125150.

Shang, K. és Marlow, P.B. [2005]: Logistics capability and performance in Taiwan's major manufacturing firms. Transportation Research Part E, Vol. 41., No. 3., pp. 217-234.

Sheffi, Y. [1990]: Third-party logistics: present and future prospects. Journal of Business Logistics, Vol. 11., No. 2., pp. 27-39.

Sink, H.L. és Langley, C.J. [1997]: A managerial framework for the acquisition of third-party logistics services. International Journal of Physical Distribution \& Logistics Management, Vol. 26., No. 3., pp. 38-46.

Skjøtt-Larsen, T. [2000]: Third party logistics - from an interorganisational point of view. International Journal of Physical Distribution \& Logistics Management, Vol. 30., No. 2., pp. 112-127.

Solakivi, T., Ojala, L, Töyli, J., Hälinen, H.M., Lorentz, H., Rantasila, K. és Naula, T. [2009]: Finland - State of Logistics 2009. Ministry of Transport and Communications Finland, Helsinki.

Solakivi, T., Ojala, L, Töyli, J., Hälinen, H.M., Lorentz, H., Rantasila, K., Huolila K. és Laari S. [2010]: Logistiikkaselvitys 2010. Ministry of Transport and Communications Finland, Helsinki.

Solakivi, T., Töyli, J., Engblom, J. és Ojala, L. [2011]: Logistics outsourcing and company performance of SMEs. Strategic Outsourcing: an International Journal, Vol. 4., No. 2., pp. 131-151.

Straube, F., és Pfhol, H.C. [2008]: Trends und Strategien in der Logistik. BVL, Berlin.

Szabó, K. [1998]: Kihelyezési hullám: A piac térhódítása a vállalati hierarchiák rovására. Közgazdasági Szemle, Vol. 45., No. 2., pp. 137-153. 
Szabó, Z. [2005]: Logisztikai hibák tragikus hatása a cég költségeire. Előadás, Budapest. Letöltve: www.mktlsz.hu/?action=program\&page=eloadas

Szegedi, Z., Prezenszki, J. [2003]: Logisztika menedzsment. Kossuth Kiadó, Budapest.

Szücs, B., Kovács, Z., és Rudolf, L. [1999]: Külső logisztikai szolgáltatók igénybevétele magyar vállalatoknál. In: MLE [1999]: Logisztikai Évkönyv. Magyar Logisztikai Egyesület, Budapest.

Tan, E. N., Smith, G., és Saad, M. [2006]: Managing the global supply chain: A SME perspective. Production Planning and Control, Vol. 17., No. 3., pp. 238-246.

Teleki, L., Bownas, M. és Reich, L. [2009]: Logisztikai outsourcing Magyarországon 2009. KPMG, Budapest.

Tempel, H. és Meißner, D. [2002]: Beschaffung und Logistik in KMU. Hochschulverbund Distance Learning, Brandenburg.

Thakkar, J., Kanda, A. és Deshmukh, S.G. [2009a]: Supply chain management for SMEs: a research introduction. Management Research News, Vol. 32., No. 10, pp. 970-993.

Thakkar, J., Kanda, A. és Deshmukh, S.G. [2009b]: Supply chain performance measurement framework for small and medium scale enterprises. Benchmarking: An International Journal, Vol. 16, No. 5, pp. 702-723.

Tirode-Bédel, M. [2006]: Logistique de la performance : PME, mesurez votre performance et gagnez en compétitivité ! Chiron, Paris.

Töyli, J., Hakkinen, L., Ojala, L. és Naula, T. [2008]: Logistics and financial performance. An analysis of 424 Finnish small and medium-sized enterprises. International Journal of Physical Distribution and Logistics Management, Vol. 38., No. 1., pp. 57-80.

Tóth, C. [2009]: Fuvarozzunk, vagy fuvaroztassunk? - A kiszervezés dilemmái a Coninvest Kft-nél. Szakdolgozat, Budapest.

Tökés, A. [2010]: Textilipari termelö kis- és középvállalkozások logisztikai gyakorlata és logisztikai fejlesztési lehetőségei. Szakdolgozat, Budapest.

Uhlig, T. és Gelinas, R. [1994]: Les PME et la sous-traitance logistique en Allemagne. Actes du Congrès CIFPME, Trois Rivières, Tome 2, pp. 725-739.

Vaaland, T. I., és Heide, M. [2007]: Can the SME survive the supply chain challenges? Supply Chain Management: An International Journal, Vol. 12, No. 1, pp. 20-31

van Damme, D.A., és Ploos van Amstel, M.J. [1996]: Outsourcing logistics management activities. International Journal of Logistics Management, Vol. 7., No. 2., pp. 85-95.

van den Berg, E. [2009]: Outsourcing for SMEs. Credit Management, pp. 24-25.

Vecsenyi, J. [1999]: Vállalkozási szervezetek és stratégiák. Aula Kiadó, Budapest.

Virum, H. [1994]: Logistikk i sma og mellom - store bedrifter. Handelshoyskolen BI Research Report, Sandivka.

von Thünen, J.H. [1826]: Die Isolirte Staat. Perhtes, Hamburg.

Vízhányó, A. [2006]: A logisztikai outsourcing dilemmái a magyarországi kis- és középvállalkozások körében. Szakdolgozat, Budapest.

Vörösmarty, Gy., Tátrai, T. és Havasi, Z. [2010]: Beszerzés helye és szerepe a magyarországi kis- és középvállalatoknál. Vezetéstudomány, Vol. 29., No. 12., pp. 36-44.

Wagner, B.A., és Alderdice, A.D.G. [2006]: Managing the distribution channel: the case of Scot Trout and Salmon. Supply Chain Management, Vol. 11., No. 2. pp. 104-107.

Wang L., Mingyua, C. és Ye, J. [2004]: On ASP-Based Platform of Logistics Management for Small- and Medium-Sized Manufacturing Enterprises and its Key Technology. In International Conference on Transport Engineering 2007. pp. 3124-3130.

Williamson, O.E. [1975]: Markets and Hierarchies. Free Press, New York.

Wilson, R. [2009]: 20th Annual State of Logistics Report. Council of Supply Chain Management Professionals, Washington. 
Wymenga, P., Spanikova, V., Derbyshire, J. és Barker, A. [2011]: Are EU SMEs recovering? Annual Report on EU SMEs 2010/2011. Kézirat, Rotterdam-Cambridge.

Yang, J. [2009]: Small and Medium Enterprises (SME) Adjustments to Information Technology (IT) in Trade Facilitation: The South Korean Experience. Asia-Pacific Reserach and Training Network on Trade Working Paper Series, No. 61., Szöul.

Zheng, J., Caldwell, N., Harland, C., Powell, P., Woerndl, M., és Xu, S. [2004]: Small firms and e-business: cautiousness, contingency and cost-benefit. Journal of Purchasing and Supply Management, Vol. 10., No. 1., pp. 27-39.

Zheng, J., Knight, L., Harland, C., Humby, S., és James, K. [2007]: An analysis of research into the future of purchasing and supply management. Journal of Purchasing and Supply Management, Vol. 13., No. 1., pp. 69-83. 


\section{A témában a disszertáció benyújtásáig született publikációim jegyzéke}

Gecse, G. [2010a]: Kis- és középvállalkozások logisztikai gyakorlata Magyarországon kitekintés a nemzetközi helyzetre. in: MLBKT [2010]: Felfelé a lejtőn - a kilábalás sikertényezöi az ellátási láncban. Az MLBKT 18. éves kongresszusa. MLBKT, Budapest. pp. 126-136.

Gecse, G. [2010b]: Magyarországi kis- és középvállalkozások logisztikai gyakorlata. Logisztikai Híradó, Vol. 20., No. 3., pp. 32-34.

Gecse, G. [2010c]: Magyarországi kis- és középvállalkozások logisztikai gyakorlata. in. Dr. Bokor Z. szerk. [2010]: Logisztikai Évkönyv. Magyar Logisztikai Egyesület, Budapest. pp. 57-61.

Dr. Bokor, Z. és Gecse, G. [2009]: Development of Hungarian logistics market with special regard to EU accession. UNECE Transport Review, Vol. 1., No. 2, pp. 93-98.

Gecse, G. [2008]: Logistics strategy of the Hungarian government. In: EASTLOG konferencia kiadvány.

Gecse, G. és dr. Nikodémus, A. [2005a]: Logisztika - Európa Terv. Comitatus, Vol. 15., No. 1-2, pp. 91-102.

Gecse, G. [2005b]: Hungarian budding clusters. In. OECD [2005]: Business Clusters. Promoting Enterprise in Central and Eastern Europe. pp. 155-182.

Gecse, G. és dr. Nikodémus, A. [2004]: Logisztika kormányzati megközelítésben. Területi Statisztika, Vol. 44, No. 4., pp. 315-331.

Gecse, G. [2003]: Hungarian SME Policy in the context of industrial restructuring. "Policy and Regulatory Options for Promoting Industrial Restructuring in ECE Region”. UNECE, Genf. 